\title{
North Carolina \\ FOREST RESOURCES and INDUSTRIES
}

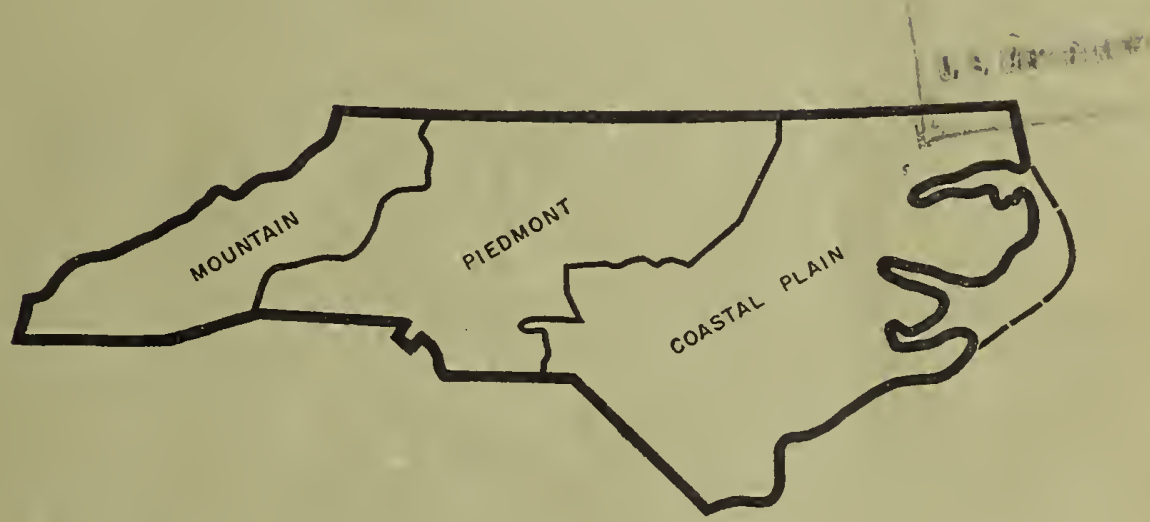

FOREST SERVICE

United States Department of Agriculture

Miscellaneous Publication No. 533 

Historic, archived document

Do not assume content reflects current scientific knowledge, policies, or practices. 


\section{FOREST SURVEY STAFF \\ Appalachian Forest and Range Experiment Station}

E. V. RoвERTs, Regional Survey Director-1936-1941

J. W. CRUIKshank, Regional Survey Director-1942

\section{STAFF ASSIGNMENTS-NORTH CAROLINA}

Field Inventory - - - - - - - W. E. Houser and N. M. White Industrial Depletion - . - . - A. D. Toler and N. M. White Mensurational Analyses - - - - T. C. Evans and G. E. Morrill Preparation of Reports - - . . - . - - J. W. Cruikshank Volume Tables - - J. W. Grard, Forest Service, Washington, D. C. Machine Tabulations - - - - P. R. WheEler, Southern Forest and Range Experiment Station, New Orleans, La.

\section{CHIEFS OF FIELD PARTIES}
J. H. BLACKERBY
W. F. MERSHON
R. W. BRYCE
R. L. Mosely
C. H. $\mathrm{C}_{\mathrm{ARR}}$
D. G. O'KELLY
J. P. $\mathrm{H}_{\mathrm{ALE}}$
W. C. Ring 
UNITED STATES DEPARTMENT OF A GR I U L T URE MiscellaneOUS PUBLICATION NO. 533 WASHINGTON, D. C., JANUARY I 944

\title{
North Carolina
}

\section{Forest Resources and Industries}

\author{
म27. 32 \\ by J. W. CRUIKSHANK, senior forester \\ APPALACHIAN FOREST EXPERIMENT STATION \\ FOREST SERVICE
}

UNITED STATES GOVERNMENT PRINTING OFFICE • WASHINGTON • 1943

FOR SALE BY THE SUPERINTENDENT OF DOCUMENTS, U. S. GOVERNMENT PRINTING OFFICE, WASHINGTON, D. C. PRICE 25 CENTS 


\section{The Forest Survey}

$\mathrm{D}$

EPENDABLE information on the supply of all raw materials is vital to the conduct of the war and to the success of current and future efforts at post-war planning. This economic survey of our forests which are an integral part of the Nation's reservoir of raw material is essential to a complete understanding of resource potentialities and of the industries depending on them. The data presented result from the first Nation-wide field inventory ever to be made of our forest land and the volume, quality, growth, and species of the timber resource. Although undertaken initially as an essential contribution to national, social, and economic welfare in peacetime, it is proving no less a necessity in wartime.

The rapidly changing conditions of our economic and social life since the Second World War began have not lessened the need for publishing the facts already gathered and the conclusions to be drawn from them. Other values of forest land, such as grazing and watershed protection, are not covered by this study.

The Nation-wide Forest Survey, authorized by the McSweeney-McNary Forest Research Act of May 22, 1928, has undertaken the task of obtaining facts essential to a system of planned forest land management and use for each of the States and forest regions, and for the Nation, and through analysis thereof is aiding in the formulation of guiding principles and policies, fundamental to permanent forest land use.

The fivefold purpose of the Forest Survey is (1) to make a field inventory of the present supply of timber and other forest products; (2) to ascertain the rate at which this supply is being increased through growth; (3) to determine the rate at which it is being diminished through industrial and domestic uses, windfall, fire, disease, and other causes; (4) to determine the present consumption and the probable future trend in requirements for timber and other forest products; and (5) to interpret and correlate these findings with existing and anticipated economic conditions, as an aid in the formulation of both private and public policies for the effective and rational use of land suitable for forest production.

The plan has been to publish the results of this investigation as they become available. Neces_ sarily, the data here presented apply to large areas and should not be interpreted as portraying correctly the forest situation for small sections, the conditions of which may be either better or poorer than the average for the entire unit or State. They supply the general background for an intensive study of critical situations. As might be expected, the recommendations included in these reports are adapted to the long-time character of timber growing and presuppose normal peacetime conditions. Any that are out of line with war requirements are obviously in abeyance for the present.

This investigation is conducted in the various forest regions by the forest experiment stations of the Forest Service and in North Carolina by the Appalachian Forest Experiment Station with headquarters in Asheville, $\mathrm{N}$. C.

$$
\begin{aligned}
& \text { Raymond D. Garver, } \\
& \text { Director Forest Survey. }
\end{aligned}
$$




\section{Contents}

Summary of Survey findings .............. Page ${ }_{1}$

The State: its environment and resources........ 3

Physical environment . . . . . . . . . . . . 3

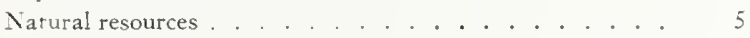

Social and industrial conditions . . . . . . . . . . . 6

Population and employment . . . . . . . . 6

Agriculture . . . . . . . . . . . . 7

Mlanufacturing . . . . . . . . . . . . . . . . 8

Power . . . . . . . . . . . . . . 9

Transportation ...... . . . . . . . . 10

Land use . . . . . . . . . . . . . . . . . . . . . . . . . . . . . . .

Agriculture .. . . . . . . . . . . . 11

Forest-land use . . . . . . . . . . . . . 12

Forest-land ownership . . . . . . . . . . . 13

The forest resource . . . . . . . . . . . . . . . . . . 16

Past and present importance . . . . . . . . . . . 16

Forest description . . . . . . . . . . . . . 17

Species. . . . . . . . . . . . . . . . . 17

Forest types . . . . . . . . . . . . . . . 18

Forest conditions . . . . . . . . . . . . 22

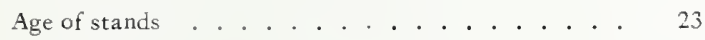

Site quality . . . . . . . . . . . . . . 24

Stocking . . . . . . . . . . . . . 25

Forest fires . . . . . . . . . . . . 26

The volume of the forest resource . . . . . . . . . . 28

Board-foot volume .............. . . 28

Volume by species . . . . . . . . . . . 28

Volume by diameter class .......... . 30

Volumes per acre .............. . 31

Cordwood volume .............. . . . . 33

Volume by class of material ......... 33

Volume by diameter class . . . . . . . . . 34

Volume per acre .. . . . . . . . . . . 34

Cubic-foot volume. . . . . . . . . . . . . 35

Pine poles . . . . . . . . . . . . . . . 35

Tanning material ............... . . . . 36

The forest-products industries . . . . . . . . . . . 38

The lumber industry. . . . . . . . . . . . . 39

Logging . . . . . . . . . . . . 40

Lumber manufacture . . . . . . . . . . 41

Value of lumber . . . . . . . . . . . . . 43

Distribution of lumber . . . . . . . . . . . 43

Other forest-products industries .......... . . 43

Veneer ................ 43

Pulp . . . . . . . . . . . . . . 45

Tanning extract .............. 46
The forest-products industries-Continued. Page

Other forest-products industries - Continued.

Dimension stock . . . . . . . . . . . 46

Fuel wood . . . . . . . . . . . 46

Minor products. . . . . . . . . . . . 46

Summary ............... . . . 47

Employment ................ . . 48

Forest increment and commodity drain . . . . . . . . . . 49

Forest increment . . . . . . . . . . . . . 49

Diameter growth . . . . . . . . . . . . 49

Net increment per acre . . . . . . . . . . 49

Net board-foot increment . . . . . . . . . 50

Net increment of the totai stand . . . . . . . . 50

Commodity drain . . . . . . . . . . . . . . . 51

Saw-timber drain . . . . . . . . . . 51

Total drain from sound trees . . . . . . . . . 51

Comparison of increment with drain . . . . . . . . 52

Saw-timber stand . . . . . . . . . . 52

Total stand ............... 53

Change in growing stock, $1937-41$......... 55

Opportunities for increasing utility of the forest resource . . . . 56

Develop the forest stand . . . . . . . . . . . 56

Increase volume . . . . . . . . . . . 56

Improve quality . . . . . . . . . . . . . 56

Improve harvesting methods . . . . . . . . 57

Protect the forest . . . . . . . . . . . 58

Fire . . . . . . . . . . . 58

Disease . . . . . . . . . . . . 58

Insects . . . . . . . . . . . . 58

Improve timber utilization . . . . . . . . . . . 59

Utilization of hardwuods . . . . . . . . . . 59

Small wood-products plants......... . 59

Integrated industries . . . . . . . . . . . 60

Portable sawrnills . . . . . . . . . . . . 60

Low-grade pine for pulp . . . . . . . . . . 60

High-quality timber for special products . . . . . 60

Increased use of chestnut . . . . . . . . . . . 61

Standardized $\log$ grades . . . . . . . . . . 61

Marketing of forest products.......... 61

Expand public ownership ............. 61

Intensify research . . . . . . . . . . . . 62

Permanent forests for North Carolina . . . . . . . 63

Public regulation . . . . . . . . . . . . 63

Private action . . . . . . . . . . . . . 63

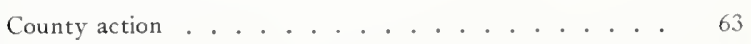

State action . . . . . . . . . . . . . . . . 64

Federal action . . . . . . . . . . . 65 
Appendix . . . . . . . . . . . . . . 67

Survey methods . . . . . . . . . . . 67

Field inventory . . . . . . . . . . 67

Increment . . . . . . . . . . 67

Drain ............... 68

Computations . . . . . . . . . . 68

Definition of terms used . . . . . . . . . . . . 68

Land-use classes . . . . . . . . . . . 68

Species groups . . . . . . . . . . 68

Species mentioned . . . . . . . . . . . . . . 68

Softwoods . . . . . . . . . . 68
Page

Appendix-Continued.

Definition of terms used-Continued. Species mentioned-Continued.

Hardwoods .............. . . 68

Forest types . . . . . . . . . . . . 70

Diameter classification ........... 70

Tree classes . . . . . . . . . . . 70

Forest conditions . . . . . . . . . . . 70

Volume estimates . . . . . . . . . . 70

Growth and drain ........... 70

Data by physiographic regions . . . . . . . . 71 


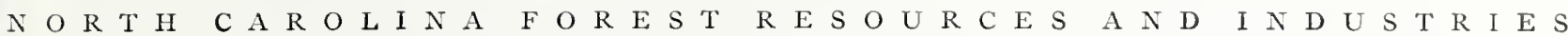

\section{Summary of Survey Findings}

i:

$\mathrm{N}$ ORTH CAROLINA is a State of varied resources, which affect the everyday life and well-being of most of the people. No single resource is a separate entity in the economic structure of the State, because the development and use of one inevitably affects the others. This is particularly true of the forest resource, which has a significant influence upon agriculture, industry, employment, finance, transportation, public water supplies, and electric power production.

The forest resource should be recognized as an integral part of the whole social and economic structure of the State. Because it contributes so vitally to the welfare of the people and industry of North Carolina, it is needful that both public officials and private citizens awake to the need for a more conservative and far-reaching plan of forest use. At the present rate of cutting the forest land will on the average be cut over once every 40 years. Young second grow th is constantly adding to the supply of merchantable timber, but because of prevailing methods of cutting and inadequate fire control the forest is being reduced in quantity, quality, and effective usefulness. To remedy this situation, sustained-yield forest management should be practiced on a large proportion of the forest land.

The following summary of factual data emphasizes the importance of the forest resource:

1. Forests occupy over 18 million acres, 59 percent of the total area of the State.

2. One-half of this forest land is in farms and in 1937 it yielded 20 different forest products with a value of $\$ 24,000$,000 , accounting for about 7 percent of the value of all farm production and equaling four-fifths of the value of the corn crop.

3. Forests help to protect the watersheds of over 100 hydroelectric developments and many municipal watersupply systems.

4. Nearly 3,000 industrial plants depend directly upon the forest for raw material, and the value of their production in 1938 was about $\$ 55,000,000$.

5. The wood-products industries rank next to textiles as a source of employment in manufacturing. In 1938 woods and mill employment in the primary forest-products industries amounted to 59,000 man-years and the strictly commercial forest-industrial work was enough to have kept 33,000 employees occupied full time.

6. About two-thirds of the timber area is in pine types and one-third in hardwood types. The loblolly pine type occupies 26 percent of the forest area and nearly 60 percent of it is satisfactorily stocked.

7. Saw-timber stands occupy 53 percent of the forest land, under-sawlog-size second grow th occupies 45 percent, and less than 2 percent is clear-cut and not being restocked. About one-half of the forest land is stocked with timber less than 40 years old.

8. In 1938 the saw-timber volume was nearly 44 billion board feet, equal to about 11 percent of the timber in the South (fig. 1) and 3 percent of that in the Nation. Twothirds of it is softwood and one-third hardwood. Sixteen billion feet, 37 percent of the total, is loblolly pine.

9. The average volume per acre of all sawlog-size ${ }^{1}$ stands is 4,280 board feet.

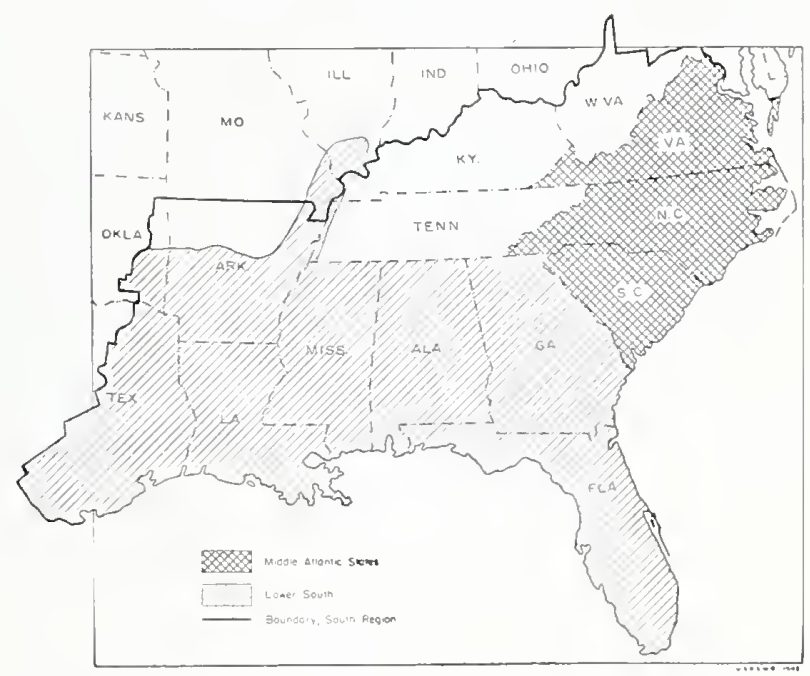

Figure 1.-Map of "the South" and "South Altantic States" as referred to in this publication.

\footnotetext{
I Definitions of terms used will be found in the Appendix, p. 68
} 
10. The total volume of all sound material in trees 5 inches d. b. h. (diameter breast high) and larger is 264 million cords, 45 percent pine and 55 percent hardwoods. Loblolly pine, shortleaf pine, and black tupelo are the most abundant species.

11. In 1938 the lumber cut was 1.4 billion board feet, placing North Carolina fourth among the States in lumber production. Average annual production for the past 35 years has been 1.2 billion feet.

12. Seven-tenths of the lumber was cut by portable mills with a rated capacity of less than $10 \mathrm{M}$ board feet per day and only 6 percent was cut by large mills, having a capacity of $40 \mathrm{M}$ feet or more per day.

13. The consumption of wood for veneer has increased from 8 million board feet in 1905 to 110 million feet in 1938. North Carolina ranks after Washington and Florida in the manufacture of veneer.

14. Four pulp and paper companies operate in North Carolina. In 1938, 406,000 cords of pulpwood were used. Total plant capacity in 1941 was 1,055 tons of pulp in 24 hours.

15. Ten plants made tanning extract in 1938, using 168,000 cords of chestnut wood and 17,500 cords of hemlock and chestnut oak bark.

16. About $5 \frac{3}{4}$ million cords of fuel wood was used in 1938.

17. Three-fourths of the annual saw-timber net increment is yielded by second-growth timber and under-sawlog-size trees reaching merchantable dimensions. There is a dearth of large maturing trees and a disproportionate volume of young timber resulting from excessive cutting of small immature trees. Mortality from all causes was equal to 11 percent of gross growth.

For softwoods, total net saw-timber increment for the State in 1938 was 1.66 billion board feet and commodity drain 1.69 billion. For hardwoods net increment was 637 million and commodity drain 530 million. These figures can be misleading because for smaller areas such as the Piedmont region softwood growth was 157 million board feet less than drain, while in hardwoods, growth-mostly in small sizes-exceeded drain only 49 million feet. The growing-stock situation in the piedmont unit is therefore much more unsatisfactory than for the entire State which points to the need for studying growth-drain relationships by as small areas as practicable. It must be kept in mind also that not all the growth is available for utilization because part of it occurs on scattered trees or is out of reach for other reasons.

18. Further evidence of the depletion of the small softwood timber is the commodity drain in terms of cubic feet on all sound trees 5 inches d. b. h. and larger. This drain was 7 million cubic feet in excess of growth annually. For hardwoods the growth exceeded drain by 82 million cubic feet. But this gain is only 1 percent of the total stand and a high proportion of the growth was on trees of small size, poor form, or low-quality species.

19. Forest stands generally are less than 50 percent stocked. Special study of the loblolly pine type-one of the best-shows only 30 percent of the saw-timber area and 15 percent of the under-sawlog-size area satisfactorily stocked. Stands of the remainder are progressively poorer down to treeless areas. Since quality is definitely tied in with tree size and thrift, the kind of trees making up the growing stock is pertinent. In North Carolina it is common practice to cut the larger and better trees and where trees are left they are usually small, and often of poor form or inferior species. Under present rate of drain and cutting practices it is impossible to build up growing stock of the desired quality and quantity. Even though growth exceeds drain in certain areas of the State, stand quality deterioration may be occuring with a decided loss in timber values.

This situation calls for increasing the utility of the forest resource by improving the quantity and quality of the growing stock through better forest practice; intensifying protection against fire, insects, and disease; expansion of public ownership; and increased forest research in timberland management, forest-products utilization, and marketing.

20. A program to develop these opportunities requires definite action by private landowners, forest industries, county, State, and Federal Governments. It should include public control of cutting practices on private forest land, more financial and technical assistance to private owners and operators by the public, and wider adoption of timbermanagement practices by forest-land owners. 


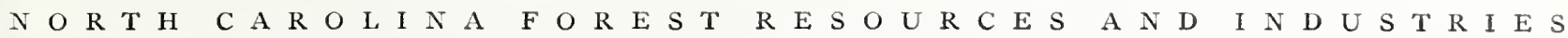

\section{The State: Its Environment and Resources}

$\rightarrow$

\section{Physical Environment}

$\mathrm{F}$ ROM the Atlantic Ocean on the east, North Carolina extends 503 miles westward to Tennessee. The extreme width north and south from the Virginia boundary to Georgia and South Carolina is 187 miles. The State's total area is 52,712 square miles, including 3,570 square miles of water. It ranks third in size among the South Atlantic States (fig. 1).

Three major physiographic regions trisect the length of the State, from the crest of the Great Smoky Mountains to the ocean (fig. 2). In the west is the rugged mountain region, across the central part is the gently rolling Piedmont Plateau, and bordering the seacoast is the wide, level coastal plain.

The mountain region occupies approximately one-sixth of the State. It is a high plateau bordered on the west by the main chain of the Great Smoky Mountains and on the east by the Blue Ridge Mountains. Several cross ranges cut the plateau into a patchwork of small basins, each with an independent drainage system. The main floor of the plateau is 2,000 to 3,000 feet above sea level, but more than 40 peaks exceed 6,000 feet and one, Mount
Mitchell, is 6,684 feet high. Much of the land on the upper slopes is too steep or rocky for cultivation, but the lower slopes are pastured and the valley bottoms are farmed intensively (fig. $3, A$ ). About two-thirds of the land is forested, chiefly with second-growth hardwoods.

The Piedmont Plateau, embracing about one-third of the State's territory, extends from the base of the Blue Ridge Mountains at about 1,000 feet elevation east to the fall line at the inland limit of the coastal plain. In contrast to the rough mountain topography, it is characterized by gentle hills and valleys. Surface features place little restriction on the use of land; cultivated fields, pastures, and woodlands are intermingled throughout the area (fig. $3, B)$. Almost one-half of the land is timbered, chiefly with shortleaf pine or Virginia pine in mixture with hardwoods.

Nearly one-half of North Carolina lies in the Coastal Plain, the broad, almost level belt of land extending inland from the seacoast an average of 150 miles. A narrow chain of off-shore islands known as "banks" forms the extreme eastern boundary. The tidewater area forms a belt 30 to 80 miles wide in which large swamps are common, some of them of several hundred thousand acres. Pocosins (marshes,

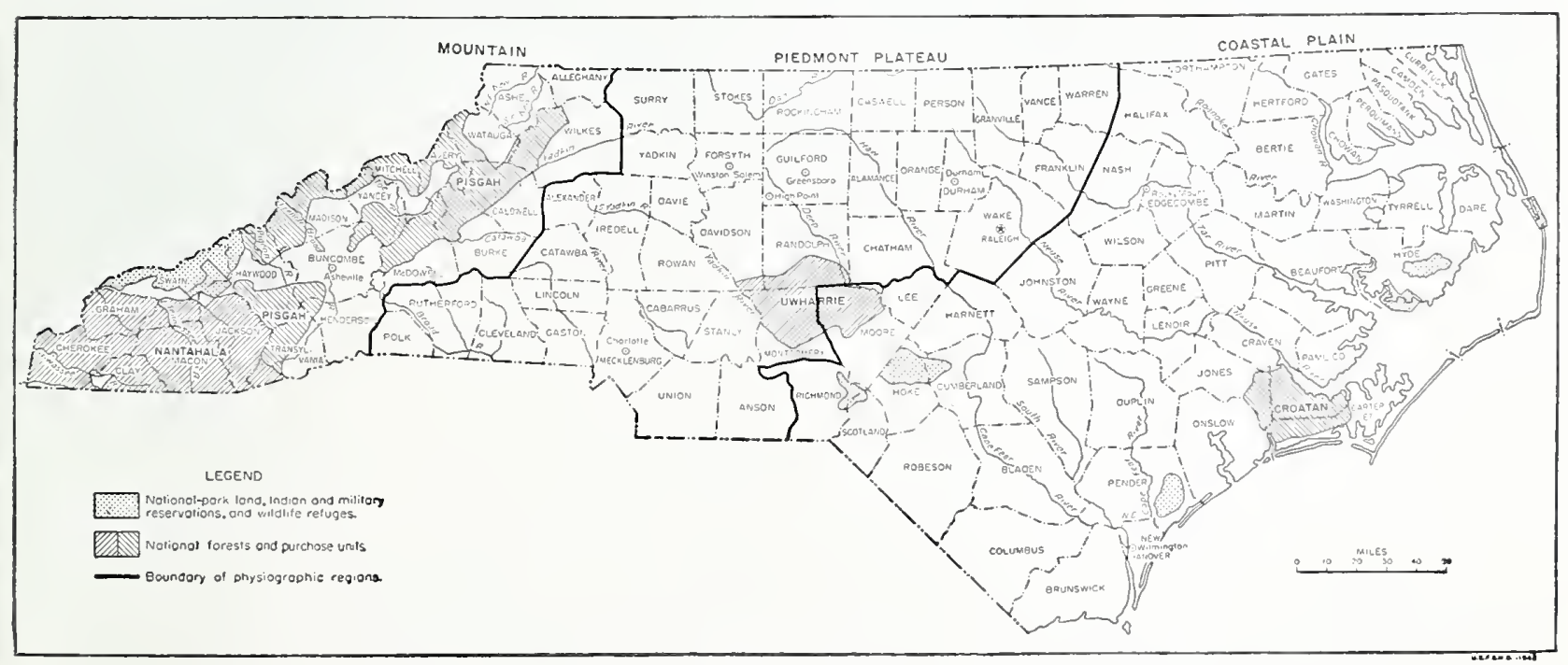

FIGURE 2.-Physiographic regions, counties, principal cities, and rivers in North Carolina. 

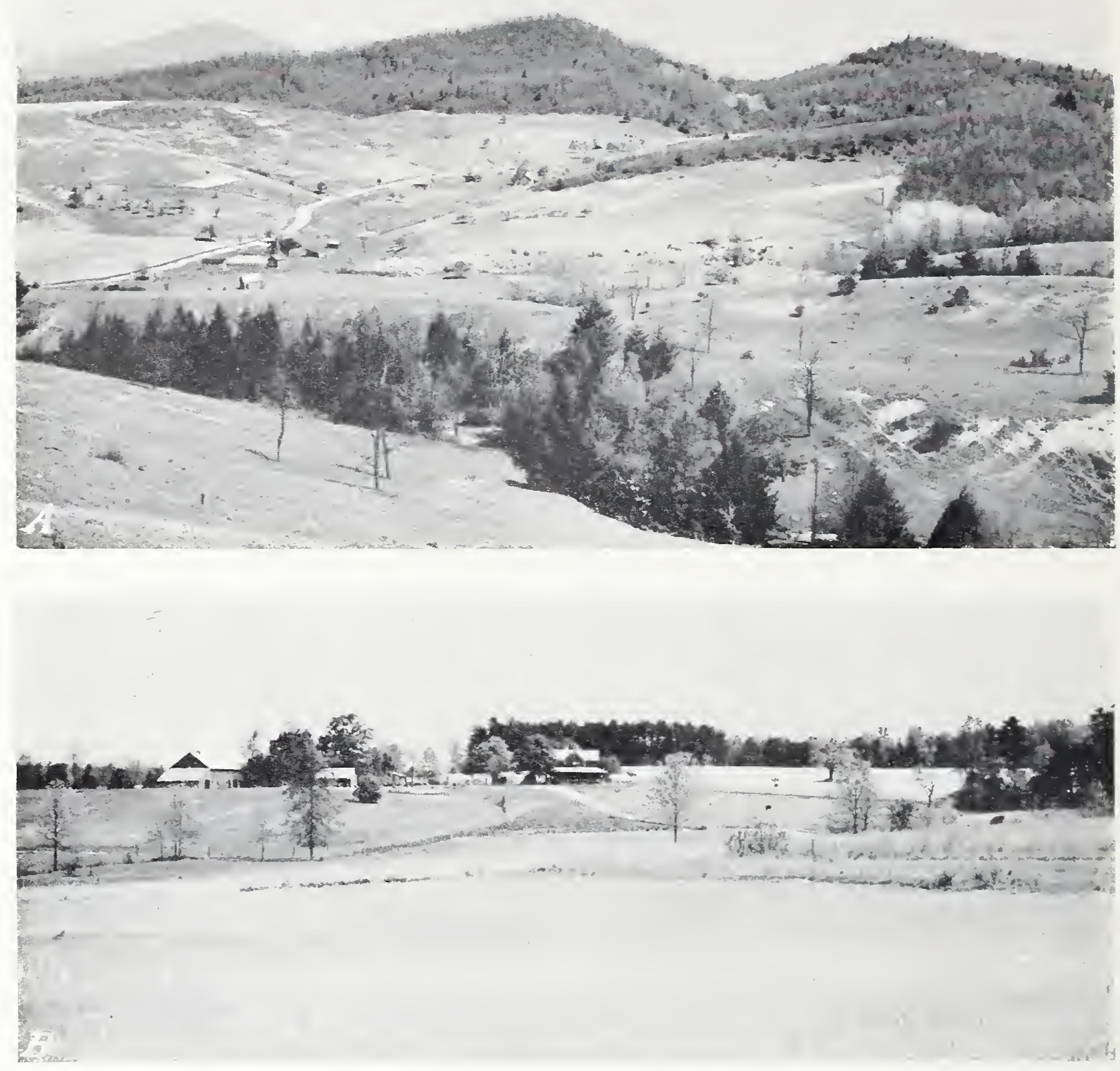

F. $55153-39488$

FIGLRE 3.- Forest and farm lands characteristic of the mountain region. A, In the less rugged mountains most of the steep slopes are forested, the lower slopes are grazed, and the valleys and flat benches are cultivated or grazed. B, Fields, pastures, and woodlands are intermingled on the gentle terrain of the piedmont.

containirg scattered pond pine) and treeless savannas are characteristic features of the landscape near the coast. The tidewater country seldom rises more than 50 feet above sea level but the western Coastal Plain proper rises graduvally by a series of terraces to an elevation of about 500 feet at its western margin. Cultivated fields are commonly restricted to the better-drained soils throughout the
Constal Plain and where drainage is poor the land is usualiy forested (fig. 4). Timber stands are not confined to the wettest sites, however, for trees grow on nearly two-thirds of all the land. About one-half ct the State's forest area is in the Coastal Plain.

The Blu= Ridge Mountains divide the rivers that flow into the Gulf of Mexico from those that flow into the Atlan- 
tic Ocean. The Hiwassee, Little Tennessee, French Broad, Nolichucky, Watauga, and New Rivers, originating on the western slope, flow west and northwest to the larger streams emptying into the Gulf. On the Atlantic slope the main drainage basins are those of the Broad, Catawba, Yadkin, Cape Fear, Neuse, Tar, and Roanoke-Chowan Rivers, flowing south or southeast to empty into the Atlantic Ocean. All of the rivers originating in the mountains are very important sources of hydroelectric power. The broad, quiet streams of the Coastal Plain are navigable by shallowdraft vessels.

The climate of North Carolina is that of the warm temperate zone with local variations partly due to the 6,000 -foot range in elevation. The mean annual temperature in the mountain region is $55^{\circ} \mathrm{F}$, in the piedmont $60^{\circ}$, and in the Coastal Plain $62^{\circ}$. Extremes of temperature for short periods range from below zero to over $100^{\circ}$. In the east the ocean tends to stabilize the temperature. The average date of the first killing frost varies from October 17 in the northwest to November 16 in the southeast. The length of the growing season ranges from about 175 days in the mountains to 275 days along the coast.

Rainfall is abundant and its distribution is generally favorable for the planting and harvesting of annual crops. According to 35 -year records the average annual precipitation is 48.1 inches at Elizabeth City in the Coastal Plain, 48.6 at Salisbury in the piedmont, and 54.8 inches at Bryson City in the mountains. Within the mountain region, however, are sharp local variations. Highlands, in Macon County, receives about 85 inches per year and Asheville, only 50 miles away, less than 40 inches. July and August are the months of greatest rainfall, but the early spring and late fall months are dry enough to cause a serious fire hazard in the forests. In general, the climate throughout the State is favorable to rapid tree growth and year-round work in the woods.

\section{Natural Resources}

Other than its forests, North Carolina has three main natural resources-soil, minerals, and water. The soils are of a wide range of types, suitable for a great variety of agricultural crops. In their natural condition practically all will grow stands of commercial timber. Those of the Coastal Plain are derived from sedimentary rocks and are mostly Norfolk, Portsmouth, Coxville, and Dunbar sandy loams with sandy clay subsoils. They possess little natural fertility, but are easily worked and próduce well when commercial fertilizers are applied. Near the coast, drainage is often inadequate for farm cropping, and extensive areas of swamp, muck, and poorly drained sandy loams are and

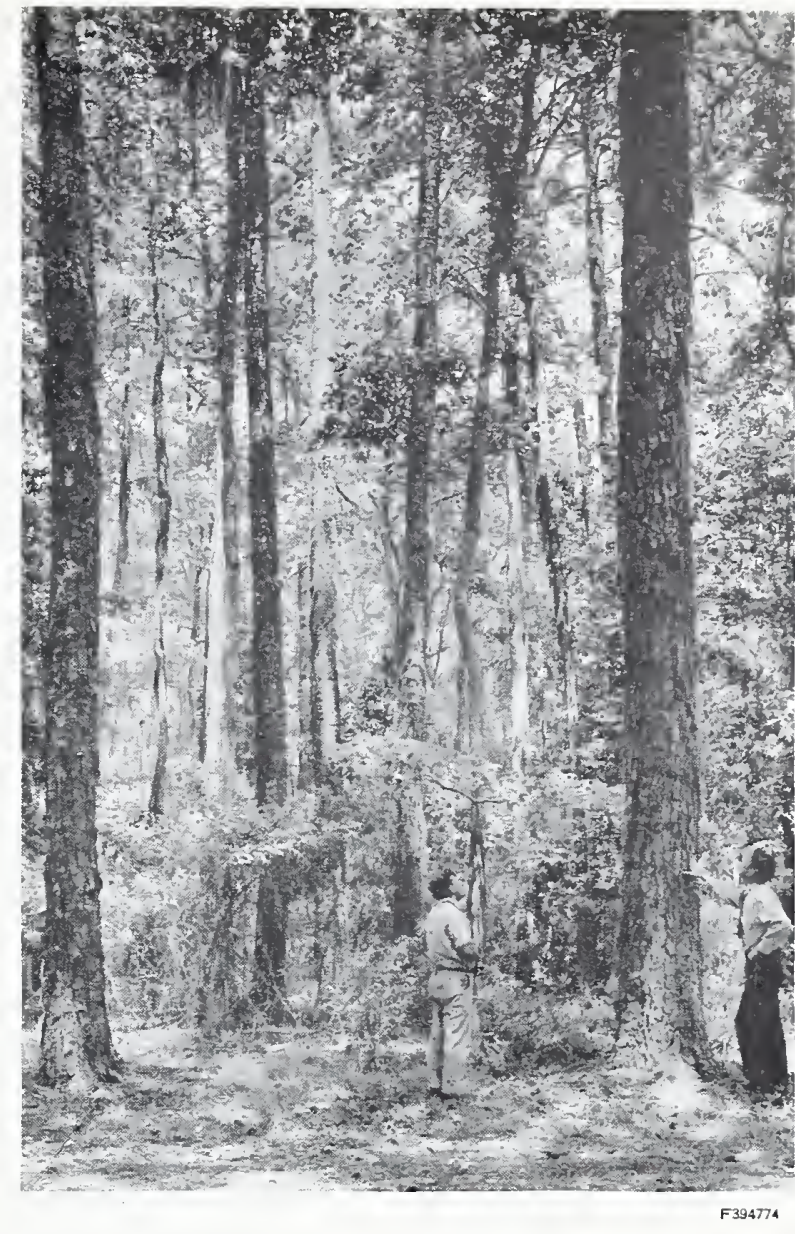

FigCRE 4.-Old fiela loblully fine growing in minture with hardwoods on moist bottom land near Wilmington.

doubtless will remain devoted to timber production. In the piedmont the most abundant soils are the Cecil red clay loams of granitic rock origin. Other important types are the Cecil sandy loams and the Georgeville silt loams. The greater part of the piedmont soils were originally suitable for cultivation, but unwise agricultural practices have resulted in serious erosion, soil depletion, and extensive land abandonment. Erosion experiments in Cecil sandy clay loam near Statesville reveal that 7 inches of topsoil would be lost in 46 years under continuous one-crop cotton production. ${ }^{2}$ Most of the abandoned fields have restocked naturally to pine and these old-field stands make up a large proportion of the forests in the piedmont and western Coastal Plain. The mountain soils are derived from the underlying rocks. Porters loam is the most abundant soil type and the texture of other important types varies from stiff clays to sandy and stony loams. Erosion is a serious

\footnotetext{
2 Bennet, H. H. soll conservation. 993 pp., illus. New York and
} London. 1939. 
limiting factor on the steeper mountain slopes. About onefourth of the land used for agriculture is on slopes of more than 20 percent and one-tenth on slopes of more than 40 percent. Timber growing is the only logical use for a large portion of the mountain soils. Throughout the State, forests now occupy abandoned fields, steep mountain slopes, eroded lands, poorly drained soils, and some good farm land. Present trends indicate that more of the soil resource will be used for timber production, but adjustments are needed to convert some of the fertile forest soils to cropland and to retire depleted cropland to forests.

North Carolina contains a large variety of minerals, but few occur in deposits of great commercial importance. The value of all minerals produced in 1937 was only $\$ 11,200,000$, according to the Bureau of Mines. Crushed granite for road construction is the most valuable product, but heavy clays used in brick and tile manufacture are a close second. These two items accounted for two-thirds of the value of all minerals in 1937 and bromine extracted from sea water by a chemical company near Wilmington accounts for a large part of the rest. North Carolina is the leading domestic source of feldspar and mica and also produces small quantities of talc, pyrophyllite, gold, silver, and several other minerals. Industries dependent upon North Carolina minerals are of local importance.

Water is one of North Carolina's most important natural resources and has contributed markedly to the rapid development of the State in supplying transportation and power and aiding industrial processes. In the piedmont and mountain regions the first settlements were often made where water power was available to turn mill wheels. At present there are over 100 commercial hydroelectric installations in the State. The locations of Washington, New Bern, and Wilmington were determined by their accessibility to both ocean and inland waterways. The abundant supply of surface and underground water, made possible by the many forest-clad slopes and verdure-protected stream banks, contributed to the development of many widely scattered smaller towns and cities.

In 1937 the North Carolina State Planning Board listed 275 communities having public water-supply systems. Of these, 128 obtained water from wells, 98 from filtered surface supplies, 31 from unfiltered surface supplies, and 18 from springs. Unfiltered surface water from the high forested mountain slopes is used by many of the mountain towns, but pollution by sewage, industrial wastes, and soil erosion has forced most of the piedmont and Coastal Plain towns to filter and treat their surface water or use deep wells.

The quality and amount of water a vailable for specialized industrial processing plants has not been accurately deter- mined, but the presence of rayon, pulp, cigarette paper, and textile-processing mills in the State indicates that the supply is satisfactory in certain localities.

In effect, full use of the water resource depends upon wise land use on the many watersheds of the State, in order to prevent soil erosion and excessive runoff, the forerunners of silting and floods. This implies a suitable balance between forest, cultivated, and pasture lands, and industry, as well as conservative forest and farm management.

\section{Social and Industrial Conditions}

North Carolina has many of the elements of a wellbalanced economy. Agriculture is extensive and reasonably diversified, yielding both cash and subsistence crops. Industrially, the State ranks first in the Nation in the manufacture of cotton and tobacco and is among the leaders in the production of lumber, veneers, and wooden household furniture. Hydroelectric power resources are abundant and still not fully developed. Transportation facilities are generally adequate and enable the State to benefit from its proximity to large consuming centers of the East. Population growth is rapid and the available manpower is divided rather equally between rural and urban activity. The State is developing rapidly but there are still many adjustments to be made.

\section{Population and Employment}

In the half century from 1890 to 1940 North Carolina more than doubled in population, and now contains $31 / 2$ million people, nearly all native-born and nearly threefourths of them white. About 46 percent live on farms, 27 percent in cities and large towns, and 27 percent in small villages and rural-nonfarm locations. Between 1930 and 1940 the urban population increased 20 percent, the rural nonfarm (outside towns of 2,500 or more) increasing 23 percent, and the farm population 4 percent. The growth of the more industrialized counties has usually been at the expense of rural counties, several of these decreasing. in population since 1930 (fig. 5). The migration of rural people to manufacturing centers has partially reduced the pressure of population upon marginal agricultural land and has afforded many workers a needed opportunity to achieve a decent standard of living.

In March 1940 the total labor force in North Carolina was about $1 \frac{1}{3}$ million people. As defined by the Bureau of the Census these are the people 14 years of age and over who were working or were seeking work. An additional million of working age were not in the labor force because of home housework, school attendance, disability, or other 


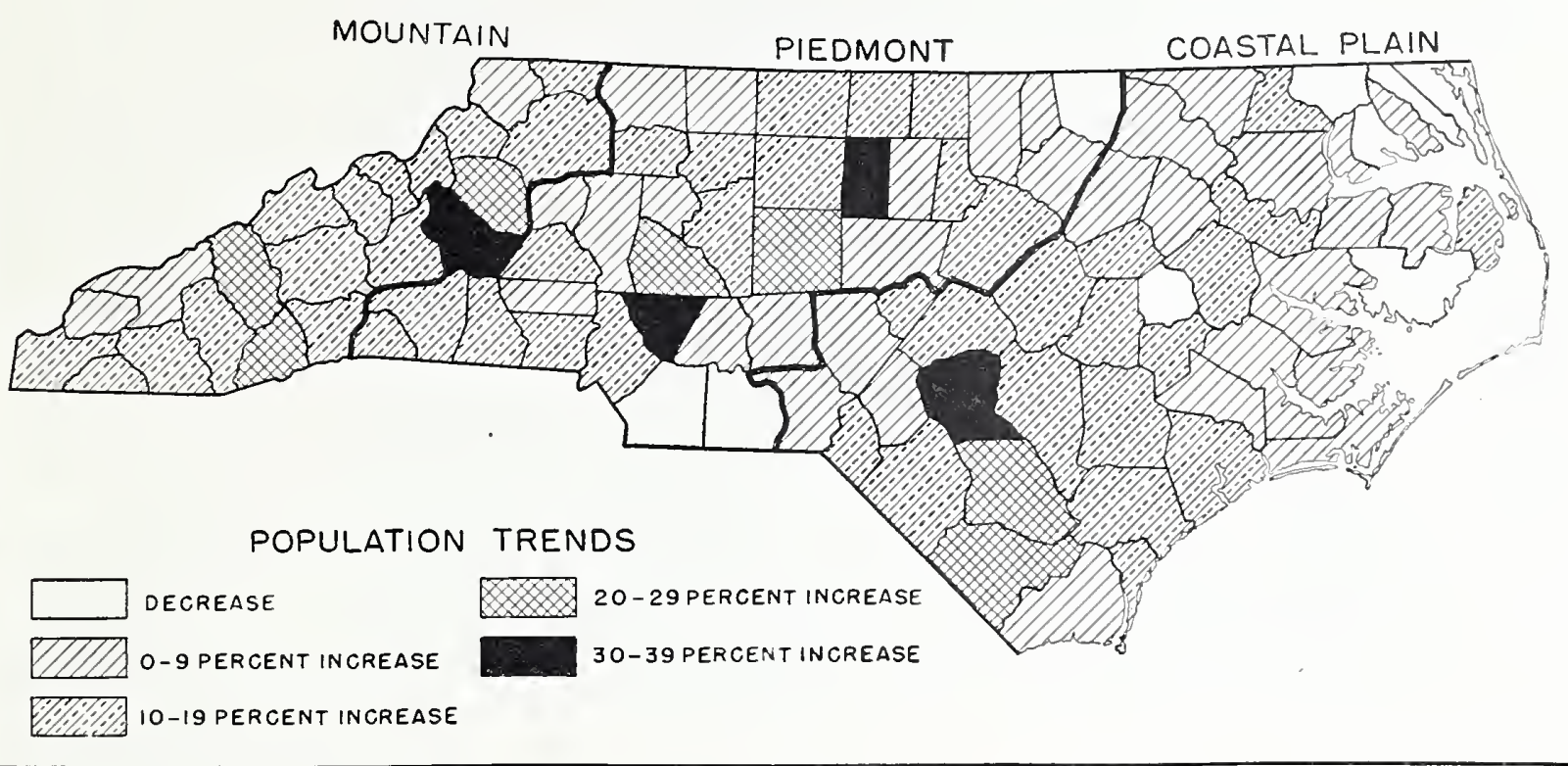

Fugure 5.-Proportionate increase or decrease in population by county, 1930-40.

reasons. Of the total labor force, 91 percent were employed, 4 percent were doing public emergency work, and 5 percent were without work, the two last classes totaling 125,000 people. Of the urban and rural-nonfarm workers 7 percent were unemployed; of those on the farms, only 3 percent. The economic status of the farm workers was not necessarily better, however, for many employed farmers received very little income from their labor.

Of the total labor force of 984,000 men and 350,000 women, 39 percent lived on farms, 34 percent in cities, and 27 percent were rural-nonfarm dwellers. By occupation, 35 percent were engaged in farming, 20 percent in manufacturing, 8 percent in retailing, 2 percent in wholesaling, and the remainder in miscellaneous activities. Average earnings of the four main groups are shown in table 1 .

TABLE 1.-Average cash earnings of workers in North Carolina, April $1941^{1}$

\begin{tabular}{|c|c|c|c|}
\hline Activity & Hourly & Weekly & Monthly \\
\hline & Cents & Dollars & Doilars \\
\hline Hired farm labor. & 13 & 6.50 & 27.75 \\
\hline Retailing & 39 & 14.53 & 62.48 \\
\hline Manufacturing & 45 & 17. 13 & 73.66 \\
\hline Wholesaling..... & 68 & 27.67 & 118.98 \\
\hline
\end{tabular}

1 Compiled from reports of the U.S. Department of Agriculture and the North Carolina Department of Labor.

\section{Agriculture}

According to the Bureau of the Census there were 278,276 farms valued at $\$ 737,000,000$ in the State in April
1940. They contained $18,845,000$ acres, about 60 percent of all the land. Of the farm acreage 48 percent was woodland, 38 percent was cropland, 7 percent was plowable pasture, and 7 percent was in miscellaneous uses. About one-third of the farms contained less than 30 acres, and only 5 farms in the State contained 10,000 acres and over The average farm consisted of 68 acres, 33 of which was woodland, 26 cropland, 4 plowable pasture, and 5 in other uses. In 1940 the average value of land and buildings per farm was $\$ 2,647$ compared to the national average of $\$ 5,518$. The truck farms of New Hanover County had the highest average value, $\$ 5,620$, and the subsistence farms of Graham County had the lowest, \$981. The proportion of farms operated by white families has gradually increased from 71 percent in 1925 to 78 percent in 1940 . Farm tenancy, though not so prevalent as it is in some States, has risen slowly, affecting 28 percent of the farm land in 1910 and 37 percent in 1940.

Agricultural crops were harvested from $6,125,000$ acres in 1939, an increase of 316,000 in a decade. Tobacco, cotton, and corn are the leading crops, but hay, winter wheat, peanuts, soybeans, potatoes, sweetpotatoes, fruit, and commercial truck crops are also important. About 775,000 acres of tobacco were grown in 1939, chiefly in the western part of the Coastal Plain, with a record yield. Since 1926 the cotton acreage had declined rapidly and the 710,000 acres grown in the western Coastal Plain and southern piedmont was the least since 1877. Beef cattle have been raised chiefly in the mountain and upper pied- 


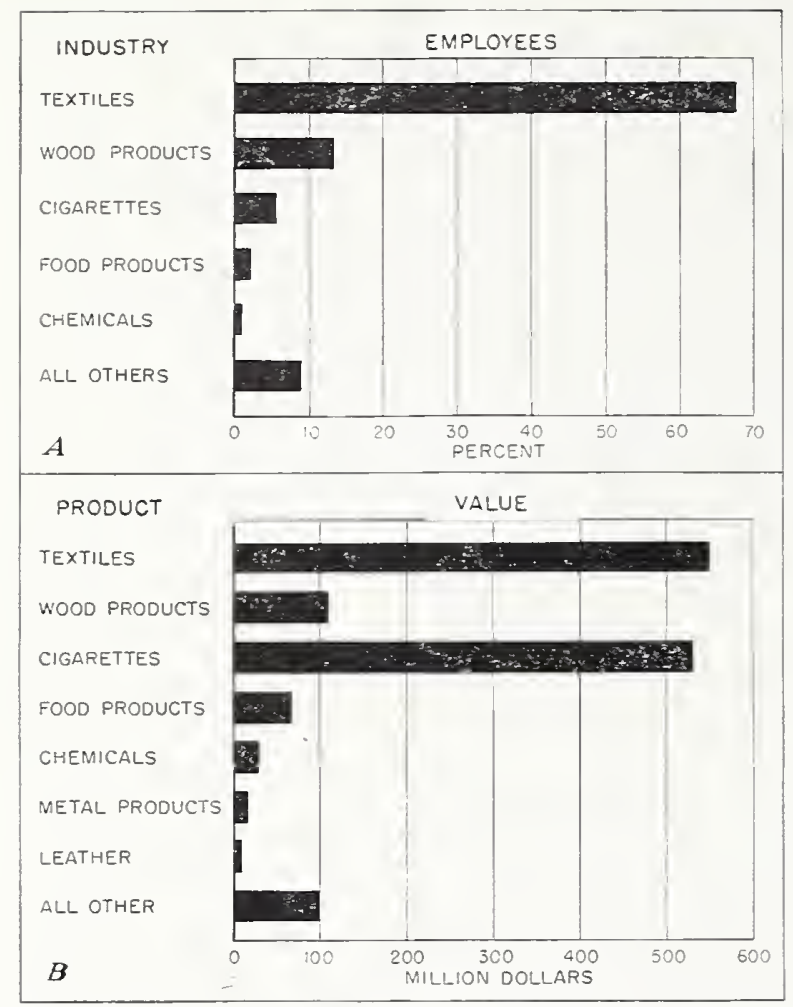

FIGURE 6.-A, Proportionate number of employees in the manufacturing industries; and B, value of products manufactured in North Carolina, 1939.

mont sections, but recently there has been a pronounced trend toward an expansion of the beef cattle industry in the Coastal Plain. Dairy cattle are raised in every county, chiefly in the piedmont and mountains, but local production of dairy products is below the State requirements. Hogs are raised for home use on about two-thirds of the farms, but commercial production centers in the counties of the western Coastal Plain. Poultry raising is general throughout the State and in 1939 more than $\$ 20,000,000$ worth of eggs and poultry were produced.

With nearly one-half of the farm acreage in woodland, forest products assume considerable importance as a farm crop, but the actual contribution to farm income has not usually been appreciated, and comprehensive and reliable information on the subject has not been generally available. The Nation-wide questionnaire survey of farm forest products, made by the Forest Service and the Bureau of Agricultural Economics in 1937, revealed that the farmers of North Carolina that year harvested wood products worth $\$ 24,000,000$, averaging $\$ 80$ per farm. About two-thirds of this total was accounted for by fuel wood, lumber, posts, and shingles produced and used on the farm, and the remainder by sales of standing timber, sawlogs, fuel wood, pulpwood, lumber, and other forest products, which amounted to $\$ 8,700,000$. North Carolina led all other States in the value of farm forest products used on farms and sold from farms.

These figures can be compared with the $\$ 361,000,000$ valuation (including nearly $\$ 20,000,000$ of Government payments) of all crops, livestock, and forest products harvested from the farms of North Carolina in 1939. Only tobacco, dairy products, and corn had a greater value than farm forest products. The evidence is clear that a wider application of good forestry practices would add even more to the farm income.

\section{Manufacturing}

In 1900 the 70,000 people employed in all manufacturing industries in North Carolina receired $\$ 14,000,000$ in wages and produced goods valued at $\$ 95,000,000$. Since then the State has experienced a great industrial expansion and the 1939 Census of Manufactures reported 3,225 plants employing 270,000 workers (fig. 6, A), who earned $\$ 199,000,000$ in wages and made products valued at $\$ 1,+20,000,000$ (fig. $6, B$ ). North Carolina led the Southern States and ranked tenth in the Nation in total number of wage earners, twelfth in wages paid, and thirteenth in value added by manufacture.

In the past few years there has been particularly rapid growth of the hosiery, rayon, and pulp and paper industries. The number of hosiery mills increased from 150 to 257 in the decade, 1931-41, and the number of rayon mills increased from 18 to 72 in the same period. Between 1939 and 1941 new plants or plant extensions costing more than $\$ 7,000,000$ were erected for a number of pulp, paper, and paperboard mills in the State.

North Carolina leads the Nation in the manufacture of tobacco products. Factories at Winston-Salem, Durham, and Reidsville, all in the piedmont, manufacture more than 50 percent of all American cigarettes, 35 percent of the smoking tobacco, and 50 percent of the Nation's plug tobacco.

Its textile industry also ranks first in the Union. In 1939 over 700 plants, most of them located in the piedmont, were making textiles, chiefly cotton yarn and woven goods, cotton knit goods, hosiery, and rayon. The towel mills of Kannapolis, the denim mills at Greensboro, and the damask mills at Rosemary are among the world's largest. In 1939 the textile mills of North Carolina contained nearly one-fourth of the active cotton spindles in the United States and accounted for 26 percent of the national consumption of cotton. The cotton farms of the State produced only one-fifth of the quantity consumed by local mills.

The primary wood-products industries will be discussed in detail later in this report. Of the secondary industries, 
FIGURE 7.-The furniture industry provides a local market for veneer. plywood, dimension stock, excelsior, and hardwood lumber.
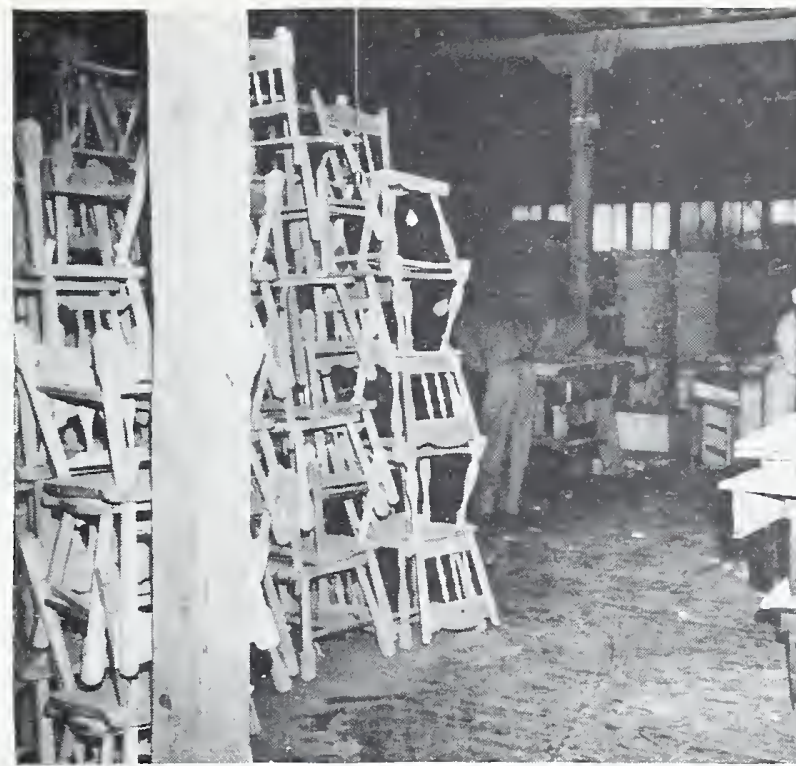

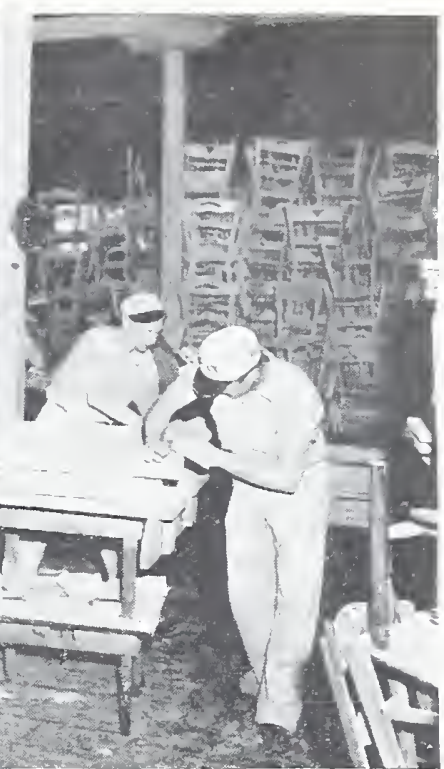

F 394738 furniture manufacture (fig. 7 ) is by far the most important. Most of the factories are located in the piedmont, and the "furniture center of the South" is High Point. The industry was established there about 1890, near a large supply of suitable timber, but it has grown so rapidly that at present most of the hardwood furniture stock is shipped in from other areas. Although some office furniture is made, wooden household furniture has continued to be the major product, not exceeded in value by the output of any other State in 1939. According to the Census of Manufactures over 200 furniture plants of all types were in operation, employing 20,000 workers who earned $\$ 14,000,000$ and made furniture valued at $\$ 59,000,000$.

Planing mills separate from sawmills are also important. The 155 planing mills operating in 1939 employed about 3,500 workers and manufactured various kinds of millwork valued at $\$ 15,000,000$.

TABLE 2.-Aierage hourly and weekly earnings of workers in selected manufacturing industries, April $1941^{1}$

\begin{tabular}{|c|c|c|c|}
\hline \multirow{2}{*}{ Industry } & \multirow{2}{*}{$\begin{array}{l}\text { Firms } \\
\text { report- } \\
\text { ing }\end{array}$} & \multicolumn{2}{|c|}{ A rerage earnings } \\
\hline & & Per hour & Per week \\
\hline Pulp and paper & $\begin{array}{r}\text { Number } \\
6\end{array}$ & $\begin{array}{l}\text { Cents } \\
69.7\end{array}$ & $\begin{array}{l}\text { Dollars } \\
29.80\end{array}$ \\
\hline Tobacco & 8 & 63. 4 & 21. 32 \\
\hline Hosiery ... . . . & 48 & 58.0 & 20.70 \\
\hline Cotton goods. & 271 & 42.7 & 16. 24 \\
\hline Furniture & 39 & 39.8 & 16.62 \\
\hline Paper boxes . . & 13 & 39.4 & 15.54 \\
\hline Lumber . . . . . & 37 & 36.6 & 14. 27 \\
\hline Fertilizer ....... & 31 & 34.8 & 15.58 \\
\hline Brick and tile... & 14 & 32.6 & 14.27 \\
\hline
\end{tabular}

North Carolina Department of Labor.
Wage rates in the manufacturing industries are reasonably high, although less than the national average of 71 cents per hour in 90 industries. A comparison of average hourly and weekly earnings in several of the leading industries is shown in table 2. Wages paid in the pulp and paper plants exceed even those paid in tobacco factories. Lumbermill employees are among the lowest paid.

Pulp and paper mills require a relatively high proportion of skilled workers, but southern labor can be quickly trained, as experience has shown. These workers have also the advantage of more employment per unit of wood consumed, a higher rate of pay, more regular work, and greater assurance of permanency. Furthermore, opportunities for training and advancement are greater in the pulp and paper than in the lumber mills and the dependent community life is usually more fully developed.

\section{Power}

The industrial expansion of the State since 1900 has been paralleled by the increases in electric energy produced. By 1938 the 947,000 horsepower of installed capacity in hydroelectric plants placed North Carolina fifth among the States in generating capacity. In 1938 about 5,0 million kilowatt-hours were imported into North Carolina and 433 million were exported. Between 1935 and 1940 great progress was made in bringing electric energy to the farms, rural industries, and small communities in the State. As of July 1940 , there were 21,000 miles of rural electric power lines serving 115,000 customers. Every county had some mileage of rural electric line, but Guilford County led with 797 miles and 6,930 customers. 
The wide distribution and the growing use of electric energy in North Carolina emphasizes the importance of the complementary relation between the forest resource and electric power. Forests benefit hydroelectric development by equalizing stream flow, by controlling erosion on watersheds, and by reducing sedimentation in stream beds and storage reservoirs. On the other hand, electric power is ideal for small wood-using plants making various kinds of special products. The increased availability of electricity should encourage development of such plants in rural sections with suitable wood resources. The construction and maintenance of many thousand miles of rural power line also creates a market for locally grown pine poles. In the 5 years ending in June 1940, approximately 420,000 poles had been used in the construction of rural electric power lines in North Carolina.

\section{Transportation}

An adequate system of transportation is particularly necessary for the utilization of the forest resource, which is spread thinly over many acres, is heavy and bulky, is often remanufactured several times, and may be consumed hundreds of miles from its origin. Highways, railroads, and waterways are all commonly used in the movement of forest products, and North Carolina has a good transpor tation system including all three.

Large-scale construction of highway's began about 1920 . In the following 16 years more than $\$ 200,000,000$ was invested in a State highway system that included a network of 58,000 miles of highway, about 9,000 miles of which were main highways with all-weather surface.

Motor transportation expanded rapidly. In 1938 more than 76,000 trucks of all types were registered in the State and at least 130 motor freight lines were operating. Trucks haul large quantities of lumber from North Carolina to consuming centers in the Northeast and they are also used to transport logs and bolts from the woods to local wood-using plants. Various lumber dealers and railroad officials have estimated that 85 percent of the lumber shipped from the piedmont to Washington, Baltimore, and Philadelphia is moved by truck (fig. 8). Delivery by motor truck has the advantages of speed, flexibility, unit shipment, ${ }^{3}$ and saving of drayage fee. Lumber trucks operating out of Washington, D. C., can obtain a load of lumber from Raleigh, N. C., in 24 hours compared to 3 days by

\footnotetext{
${ }^{3}$ ERNST, W. JR. AN ANALYSIS OF MOTOR TRICK TRANSPORTATION CF LUMBER TO NORTHERN CONSLMING MARKETS FROM CENTRAL NORTH CAROLixA. 1941. [Unpublished thesis. Copy on file at Duke University, Durham, N. C.l
}

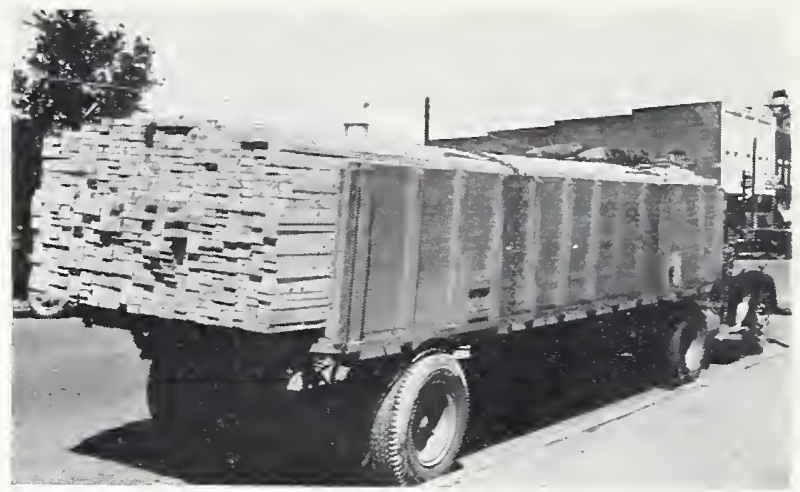

$F=9868$

FIGL RE 8.-Truck carrying $12 \mathrm{M}$ board feet of North Carolina lumber to Washington, D. C., a trip of 375 miles.

rail. In housing construction, all the material for a house can be delivered in one load. Motortruck tariffs per 100 pounds of lumber are almost identical with rail tariffs between the same points and in a few cases are a few cents higher, but the drayage fees saved vary from $\$ 1$ to $\$ 1.50$ per $\mathrm{M}$ board feet.

The improvement of highway transport, as well as a decreased supply of timber, has had its influence upon the railroads of North Carolina. Between 1920 and 1937 the railway mileage decreased from 5,522 to 4,764 miles. The Norfolk Southern Railroad, operating between Norfolk, Va., and Charlotte, N. C., carried 695,000 tons of forest products in 1920 but only 377,000 tons in 1938 ; even so, forest products made up 17 percent of the 1938 total.

The navigable waterways of North Carolina, restricted to the Coastal Plain, carry only small quantities of forest products from the woods to the mills. Pulpwood is barged to Plymouth, sawlogs to Belhaven, Washington, Bridgeton, and New Bern, and veneer bolts to Wilmington. Finished lumber is also shipped by water from Elizabeth City to northern markets. Small shipments north may be made from Wilmington, but it is safe to assume that these are unimportant. In 1936, 7,000 tons of West Coast lumber entered through this point.

\section{Land Use}

When the first colonists came to North Carolina, nearly 300 years ago, practically all of the land was forested. Since then agriculture has become the most important industry in furnishing employment, directly supporting 46 percent of the population and producing crops valued at $\$ 361,000,000$ annually, but even now only one-third of the land is used for cultivated crops (table 3 ). 
TABLE 3.-Land area classified according to use, 1938 1.

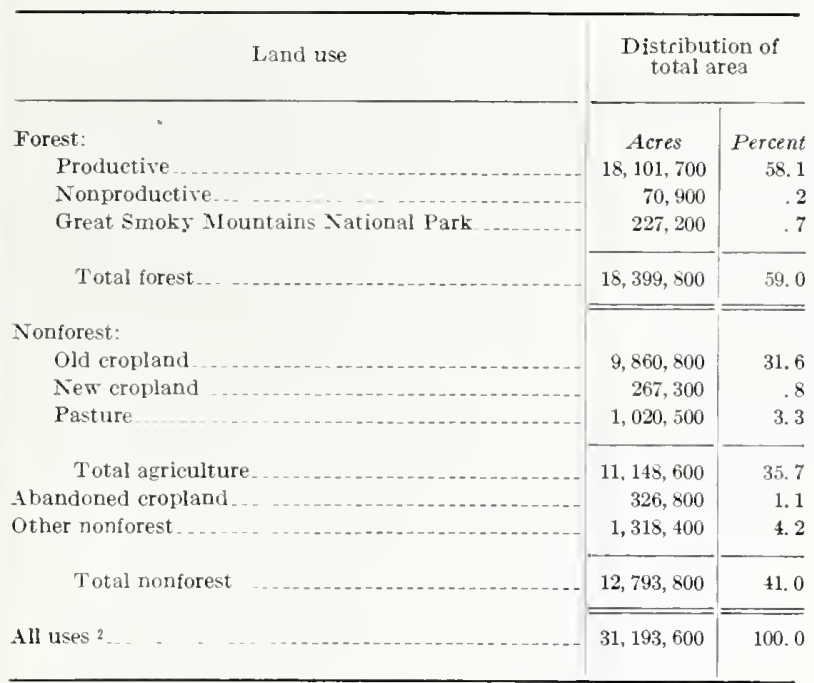

1 Data obtained by Forest Survey.

2 According to area revisions published by the Bureau of the Census in April 1941 , the State contains $31,450,880$ acres.

\section{Agriculture}

In the tidewater much of the land is too wet for cultivation without expensive drainage and in the mountains the rugged topography limits the cultivable acreage (fig. 9). According to the Census of Agriculture crops were harvested from 22 acres on the average farm in 1939. Some have high per-acre yields, but the small acreage usually means a low income per farm operator.
During the past 15 years the total amount of land used for crops has not changed greatly, but there has been a marked change in cropping practices. Between 1924 and 1939 , the acreage of cotton was reduced more than one-halt and the consequent loss in cash farm income of $\$ 60,000,000$ to $\$ 80,000,000$ has not been entirely replaced by increased production of other crops, despite an additional cash income of $\$ 40,000,000$ from nearly double the former acreage in tobacco. Truck crops, potatoes, soybeans, and peanuts have also increased in production but have brougint lower prices. A large part of the former cotton acreage is now devoted to the production of grains and hay. As cattle feed, these crops will raise the home standard of living and provide considerable cash income, but the change from a cotton economy to other forms of land use is still a major problem in the piedmont and western Coastal Plain.

Another feature of land use that bears upon timber production is the cycle of land clearing and land abandonment that has accompanied agricultural development. In 1938 the total acreage of abandoned cropland was greater than the area of recently cleared cropland (table 3 ), but the difference was not great enough to indicate a definite trend in either direction for the State as a whole. In the southeastern part of the Coastal Plain, newly cleared cropland was almost twice the abandoned area, but in the mountains the abandoned cropland was nearly five times as extensive as the new cropland. In the piedmont, clearing and abandonment were nearly in balance, but a large part of the entire area has already been cleared, abandoned, and natu-

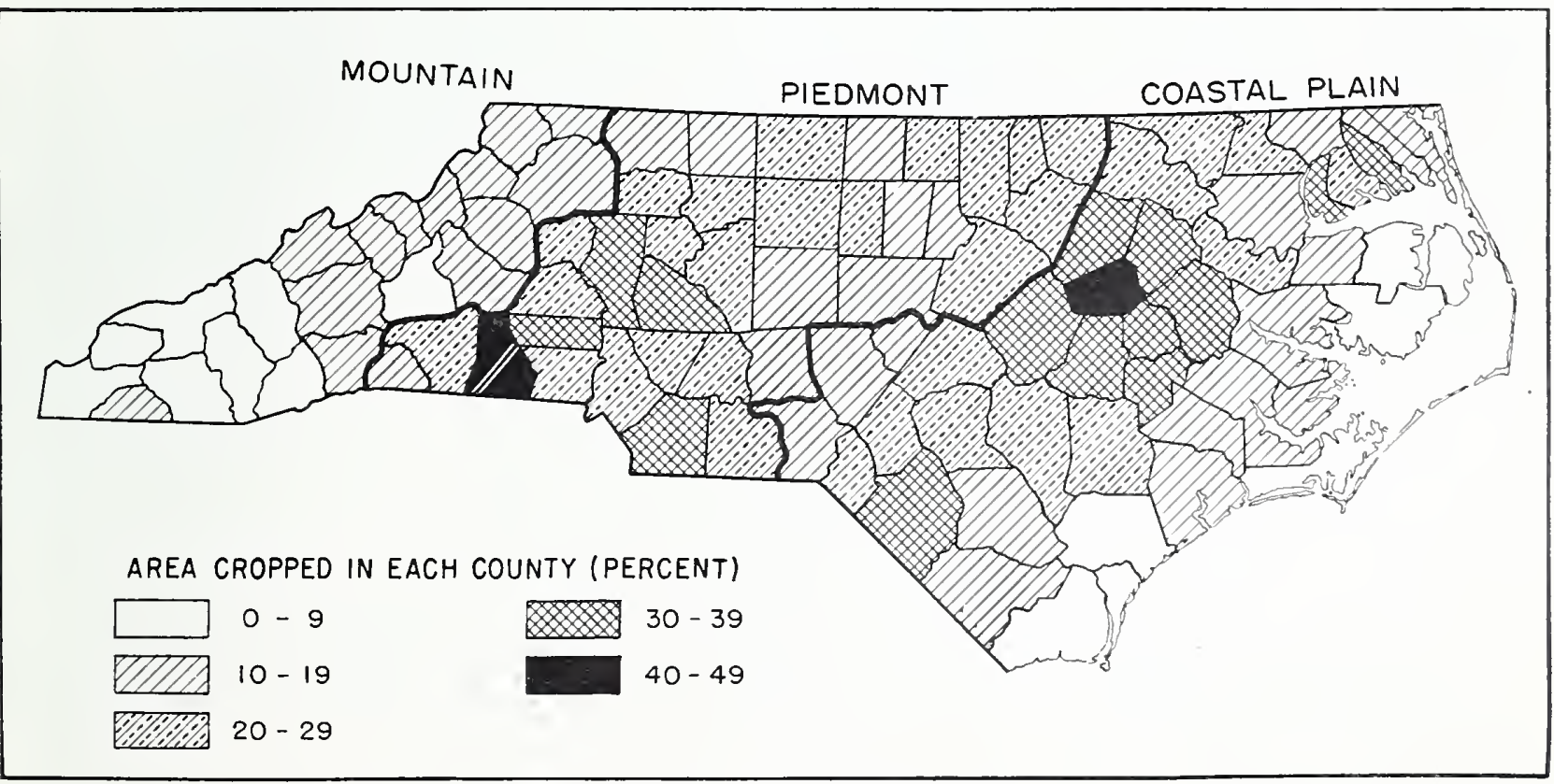

FiGURE 9. Proportion of land used for crops by county, 1939. 


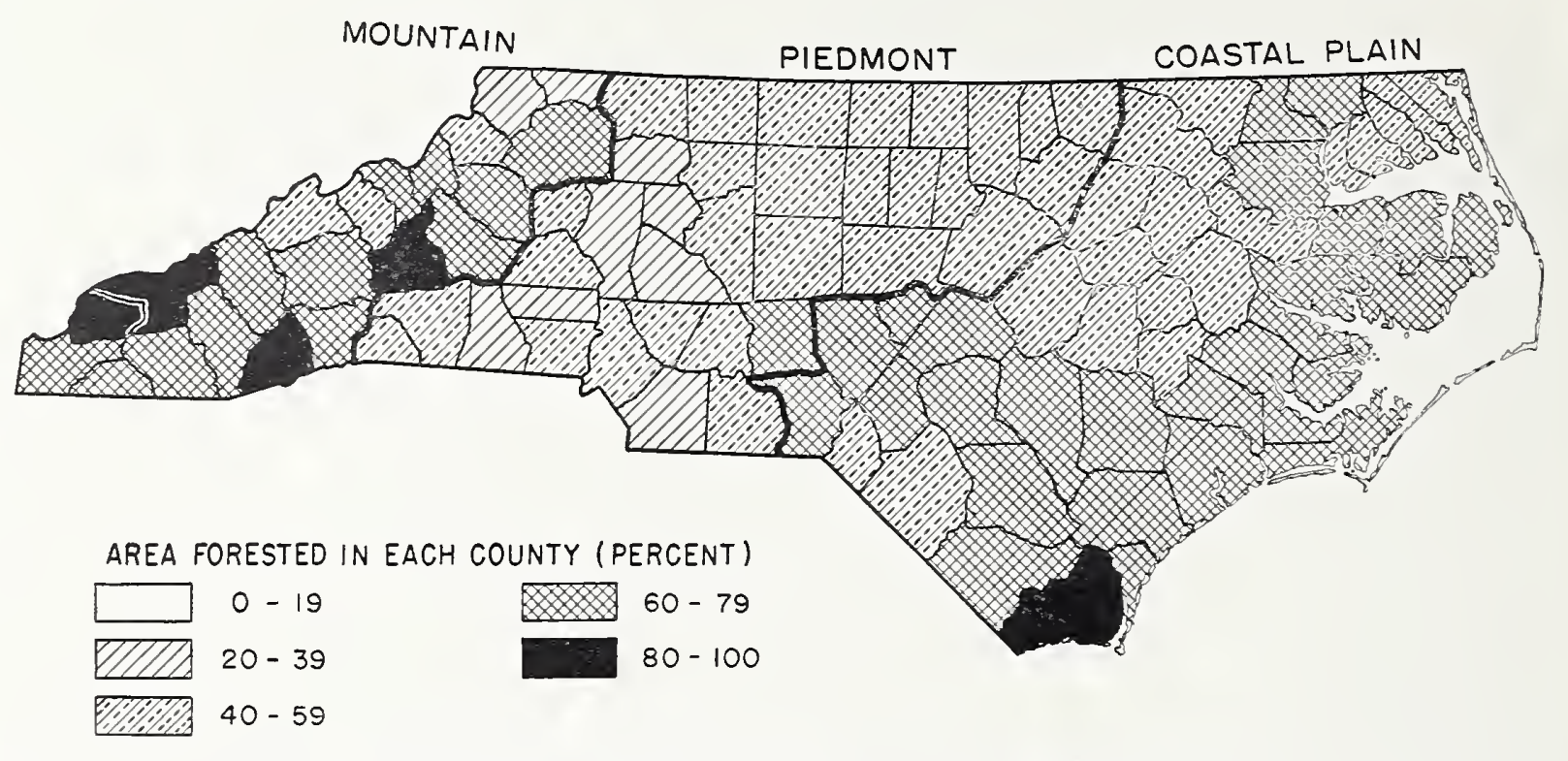

Figure 10.-Proportion of land in forest by counties, 1939.

rally restocked with timber at least once. The resulting old-field pine stands are generally much inferior in quality to forest timber. Many of the abandoned fields scattered throughout the State will restock satisfactorily through natural seeding, but the greater portion of the 327,000 idle acres must be planted if the land is to be productive within a reasonable time. It is not invariably true that abandoned cropland should be converted to forest land, but timber production is one way to use and at the same time rebuild depleted soils.

Approximately 3 percent of the land in the State is open pasture. Nearly three-fifths of this land is located in the mountains, notably in Ashe, Allegheny, Madison, Haywood, and Watauga Counties. Grazing is also important in the western piedmont; Iredell, Guilford, and Rockingham Counties each contain over 20,000 acres of open pasture land, according to the 1940 Census of Agriculture. Improved pastures occupy less than 1 percent of the land area of the Coastal Plain. The State-wide trend is toward an increasing area of open pasture, for the Census of Agriculture indicates a 40-percent increase between 1924 and 1939.

\section{Forest-Land Use}

In North Carolina timber production is the predominant form of land use. Over 18 million acres, 58 percent of the total area, is now productive forest land and less than 71,000 acres has been classified by the Forest Survey as nonproductive. In five counties over 80 percent of the land is forested (fig. 10). Less than 300,000 acres is clearcut and not yet restocking. The relative extent of this and other classes of timber-productive land is approximately as follows:

Percent

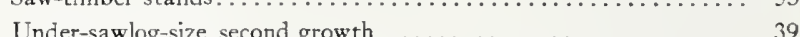

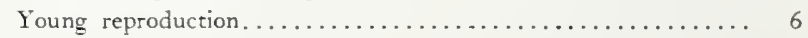

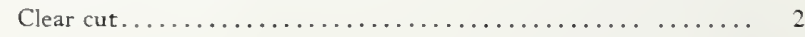

$\overline{100}$

Commercial timber production is seldom hampered by the other forms of forest-land use. Recreation is undoubtedly one of the most important of these. Hunting, fishing (fig. 11), and camping are enjoyed by a large proportion of the local people, and out-of-State visitors who come to enjoy the recreational advantages make an important contribution to the total income of the State. The Division of State Advertising estimates that 3,000,000 motor tourists spent about $\$ 100,000,000$ in North Carolina in 1939 , or $\$ 28$ for each inhabitant of the State. Many of these came to visit the national forests, and the Federal and State parks. In 1940 the recreation areas established by the Forest Service on the Pisgah, Nantahala, and Croatan National Forests were visited by about 432,000 people, equivalent to 12 percent of the State population.

Watershed protection is a valuable function of the mountain forests and, to a smaller degree, those of the piedmont. Both the Nantahala and Pisgah National Forests were established under the terms of the Weeks Act of 1911, which authorized purchase of forest land 
valuable for the protection of navigable streams. The forest cover on the steep slopes of these two forests and the Great Smoky Mountains National Park helps to prevent erosion, retards silting of power reservoirs, reduces flood crests, and helps to maintain an all-year flow of water as well as valuable water storage. Water from the Pisgah National Forest supplies several mountain towns and a large paper plant, and provides part of the requirements of two other large plants. Water from both private and public forest land contributes to the steady operation of about 100 hydroelectric plants in the mountains and piedmont. Protective strips of forest land are maintained by power companies around most of the larger lakes that serve as reservoirs. Several cities and towns in the mountains and a few in the piedmont own forested municipal watersheds. With over 30 towns and communities using unfiltered surface water, this form of land use should logically increase.

Cattle grazing is becoming an important use of part of the forest land in the Coastal Plain. Loss of markets for cotton and tobacco, wider planting of soil-conserving crops that yield supplementary cattle feed, and an attractive price for beef have all accelerated the swing to beefcattle production. Between 1938 and 1940 the number of beef cattle was increased from about 10,000 to 20,000 . If there is continued expansion of this industry, it will lead to the use of many thousands of acres of forest land for combined grazing and timber production.
The hardwood forests of the mountain region were used rather intensively for grazing from the time of early settlement until shortly after 1900 . Sheep, hogs, goats, and cattle were allowed free range and livestock concentrations as high as 1 animal unit to 7 acres existed in some localities. This intense grazing caused serious damage to the young growth, resulted in the consumption of a large part of the oak mast, and in effect tended to prevent the establishment of new crops of young trees. The damage was augmented by forest fires, set for the dual purpose of destroying the underbrush and encouraging the development of grass. The damaging effect of grazing upon the hardwood forests was recognized early by the Forest Service and commercial grazing was prohibited on the Pisgah and Nantahala National Forests soon after their establishment. This action was influential in reducing the amount of grazing in privately owned hardwood forests. With more effective Federal and State fire protection, the underbrush and young second growth in the hardwood stands restocked the land so thickly that administration of commercial herds became increasingly difficult. Hardwood-forest grazing is now limited chiefly to small numbers of domestic stock.

\section{Forest-Land Ownership}

Complete information on landownership in the State is not available, but it is reasonably certain that about 90 percent of the forest land is in private ownership. In 1935 more than half of the forest land was in farms (table

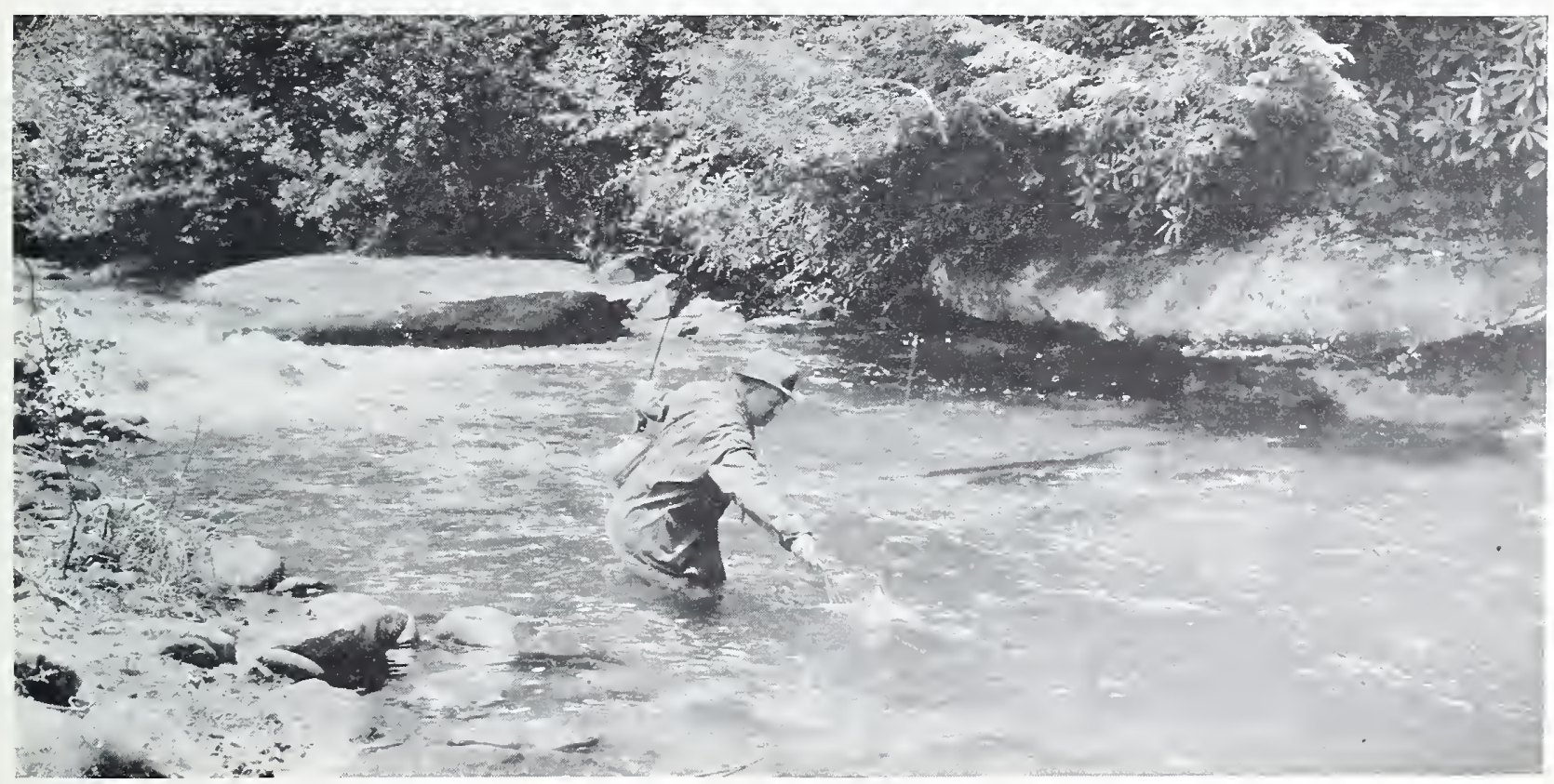

FIGURE 11.- The sport proitded for thousands of fishermen each year by the clear mosntain streams is greatly eiahanced by the densely wooded slopes. 


\begin{tabular}{|c|c|c|}
\hline Ownership & \multicolumn{2}{|c|}{$\begin{array}{l}\text { Distribution of } \\
\text { forest area }\end{array}$} \\
\hline Prisate: & Acres & Percent \\
\hline Farm roodland $(1935)$ & $10,094,700$ & 51.9 \\
\hline Industrial owner (1938) ... & $1,077,200$ & 5.8 \\
\hline Inrestment ow ners (1938) . . .... & 893,000 & 4. 9 \\
\hline Power companies ${ }^{1} \ldots$ & $200,0 C 0$ & 1. 1 \\
\hline Huntíng preserres ${ }^{1}$ & 100,000 & .5 \\
\hline Undetermined . . ...... & $4,2 \pi, 500$ & 23.2 \\
\hline Total. & $16,642,400$ & 90.1 \\
\hline Public: & & $=$ \\
\hline (1941) & & \\
\hline National forests & 952,700 & 5,2 \\
\hline National parks. & 240,400 & 1. 3 \\
\hline Military resersations & 187,500 & 1.0 \\
\hline Indian reserration & 35,000 & .2 \\
\hline Wildlife refuges $\ldots . . .$. & 13,500 & .1 \\
\hline State forests_.......... & 40,000 & .2 \\
\hline State parks & 17,200 & .1 \\
\hline State game refuge. ....... & 130,000 & .7 \\
\hline Tniversity forests....... & 93.000 & .5 \\
\hline Municipal watersheds.... & 48,100 & .3 \\
\hline Total & 1. 760.000 & 9.6 \\
\hline All forest land. & $18,399,800$ & 100.0 \\
\hline
\end{tabular}

Estimated.
4). The ownership of 47 percent of the farms, operated by tenants, rests with townspeople, local bankers, and insurance companies. Nearly one-half of the industrial forest land was owned in tracts of more than 50,000 acres, located in the Coastal Plain, and owned to a considerable and increasing extent by pulp and paper companies. Of the forest land held simply as an investment, two-thirds was in two parcels in the Coastal Plain owned by a railroad and an insurance company. Nonoperating lumber and mineral companies in the mountain region own most of the remainder. Power companies own forest land near their dams in the piedmont and mountains, the total being conservatively estimated at 200,000 acres. The acreage in hunting clubs is undoubtedly larger than that recorded.

Of private forest land of undetermined ownership about 3.8 million acres lie in the Coastal Plain and along the rivers extending up into the piedmont. A large proportion is bottom-land and swamp hardwoods. Very little is in active industrial ownership; rather it is held by heirs of defunct lumber companies, by banks, investment interests, drainage promotional interests, and estates. The remain-

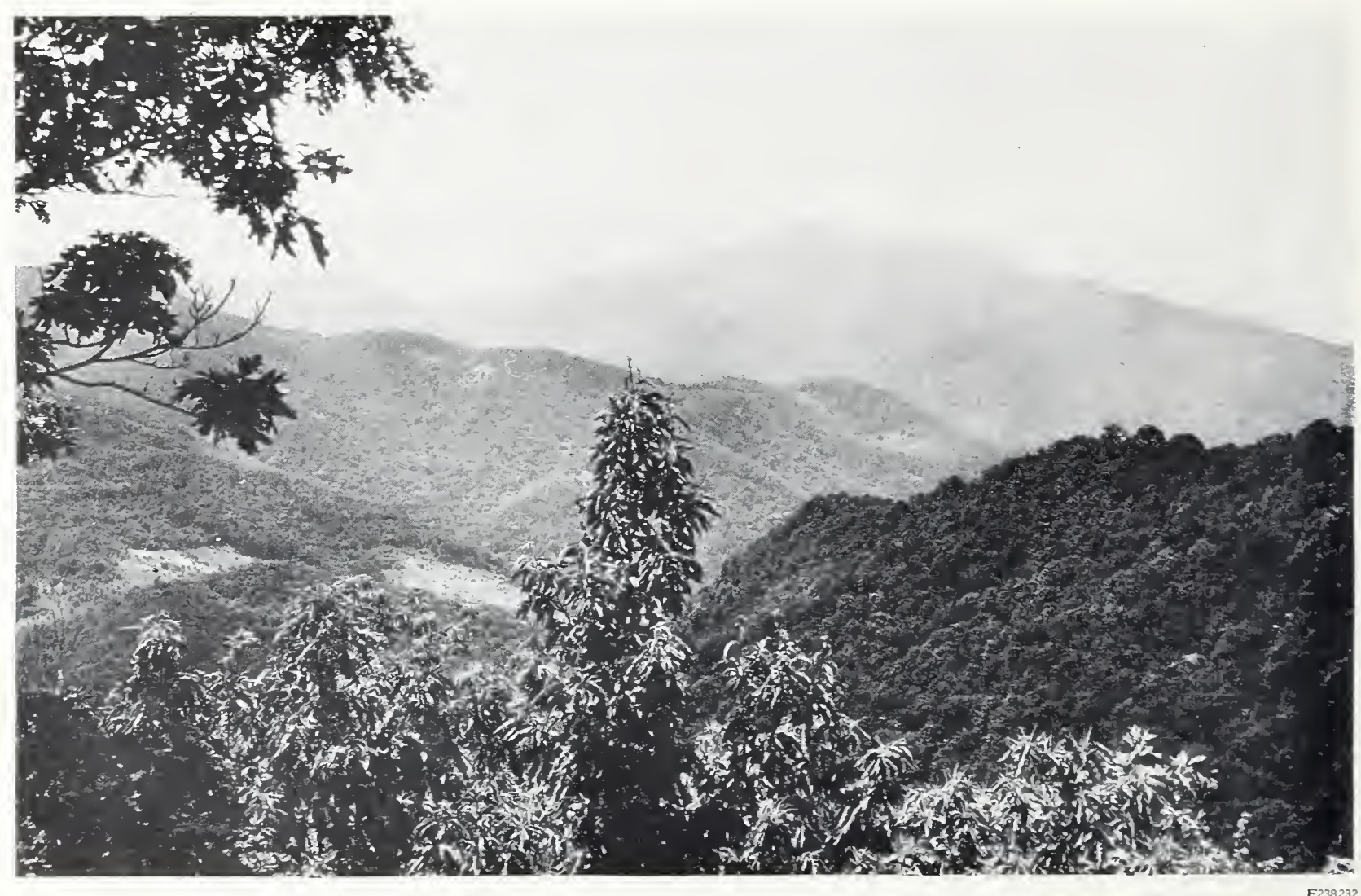

Figure 12.-The Pisgah and Nantahala National Forests comprise nearly 800,000 acres of foresked mountain land saluable for timber production, watershed protection, and recreation. 
ing private land, about 0.5 million acres, is located in the mountains and is chiefly owned by individuals, estates, and hunting clubs.

About one-half of the 1.8 million acres in public ownership is in national forests, mainly in the Pisgah and Nantahala National Forests in the mountain region (fig. 12), but other areas administered by the Forest Service include more than 100,000 acres in the Croatan National Forest in the Coastal Plain and, as of June 30, 1940, nearly 25,000 acres in the Uwharrie Ranger District in the southeastern piedmont. Parts of North Carolina in national parks include about 227,000 acres in the Great Smoky Mountains National Park and nearly 16,000 in the Blue Ridge Parkway. In 1940 and 1941 several new military reservations were established in the Coastal Plain. The forest area shown in table 4 is that of Fort Bragg, Cherry Point Marine Base, New River Marine Base, and Camp Davis. The
Cherokee Indian Reservation is situated in the mountains, adjacent to the Great Smoky Mountains National Park. Wildlife refuges in Hyde and Dare Counties, under the supervision of the United States Fish and Wildlife Service, contain nearly 100,000 acres, less than 15,000 of which is forested.

The 40,000 acres of forest land in Bladen County, formerly administered by the Soil Conservation Service, has been classified as a State forest because it has been leased to the North Carolina Department of Conservation and Development for 99 years. Six State parks, ranging in size from 142 to $t, 000$ acres, have been established to preserve areas of natural beauty and of scientific and historical interest, and to provide public recreational areas. University forests include several forested areas in the Coastal Plain and piedmont administered by Duke University and North Carolina State College. 


\section{The Forest Resource}

$\because$

\section{Past and Present Importance}

$\mathrm{F}$ ORESTS have been a source of revenue and employment to the people of North Carolina from the time of the first permanent white settlement about 1650 somewhere to the east of the Chowan River. The seemingly boundless forest affected the everyday life and policies of the developing colonies. In 1732 Governor Barrington wrote to the Colonial Secretary ${ }^{4}$ in England that "abundance of sawmills are erecting here by which the builders propose to carry on a trade in boards and other sawed timber." And again, about that time, he wrote of "the granting 5,000 acres or more to each owner of a mill."

As early as 1750 , longleaf pine lumber was exported from Wilmington to the West Indies and England. Exploitation of the forest resource did not begin on any considerable scale, however, until after the erection of the first steam sawmill at Wilmington about 1818. From 1820 to 1880 , lumber production remained at a fairly constant level. Then large-scale logging began in the virgin longleaf pine stands of the Coastal Plain and in less than 20 years most of them were cut out. About 1900 the lumber industry turned to the loblolly and shortleaf pine stands, where operations have continued ever since. About this time, too, band-saw mills began to cut the virgin hardwoods of the North Carolina mountains. Large sawmills were not established in the piedmont because the early settlers destroyed most of the virgin timber there in clearing land for agriculture.

From 1900 the cut of all species was gradually increased, reaching some 2 billion board feet in 1909 and 21/4 billion feet in the peak year, 1914. By this time a large part of the rich accumulation of virgin timber was gone, and the forest industries perforce began adjusting requirements to the periodic yields of second-growth timber. This adaptability to changing conditions has enabled them to continue to flourish, for the second-growth timber, although usually of inferior quality, has restocked plentifully most of the cut-orer forest land of the State.

"Saunders, W. L., the colonial records of North carolina. $10 \mathrm{v}$. Raleigh, N. C. 1886.
Naval stores, produced first in Virginia soon after 1600 , were staple products of North Carolina by 1700. Copper stills for the distillation of turpentine were introduced in 1834. With the passage of the British free trade law of 1846 and the increasing use of turpentine in the paint and varnish industries, such emphasis was placed upon the production of naval stores that lumber was temporarily of secondary importance. The naval stores industry grew rapidly, except for the period of the Civil War, reaching maximum production between 1870 and 1880 . In the last year of this decade North Carolina exported nearly half a million barrels of turpentine. But with the expansion of longleaf pine, logging naval stores production fell off steadily, dwindling to an insignificant 160 barrels in 1940.

The present-day forest resource is one of North Carolina's most valuable assets. At a conservative estimate, it has a stumpage value of $\$ 188,000,000$ distributed as indicated below and summarized in figure 13 .

Loblolly pine ......................... \$79,427,500

Shortleaf pine.......................... $\quad 31,608,600$

Red oaks.............................. 12,363,500

Sweetgum .............................. 9, 9,551,200

White oaks ........................... 9,062,300

Tupelos. . . . . . . . . . . . . . .

Yellow poplar............................ $\quad 6,246,400$

Pond pine............................. $5,274,600$

Longleaf pine . . . . . . . . . . . . . . . . .

Cypress............................. 3,739,400

Virginia pine............................ 2, 2,256,200

White pine........................... 1,677,200

Chestnut............................. $\quad 1,632,200$

White-cedar. . . . . . . . . . . . . . . . . . . . . . . $1,029,900$

Other softwoods....................... 1,198,300

Other hardwoods . . . . . . . . . . . . . $\ldots \ldots \ldots \ldots . \quad 9,574,100$

Total ................................

Approximately 3,000 primary wood-using plants get their raw material from the forest and employ at least 33,000 workmen in the manufacture of forest products valued at about $\$ 50,000,000$ annually. By using building material that is grown and manufactured locally, North Carolina people each year save several million dollars, representing the extra cost of obtaining the material from other sources. Forest lands account for about 7 percent of 
the property-tax base, and the proportion can be increased by building up forest productivity. Timber is also a valuable farm crop. The farmers of North Carolina received in cash nearly $\$ 9,000,000$ through the sale of forest products in 1937, and in addition used home-grown wood worth $\$ 15,000,000$.

The forest resources of North Carolina are also significant from a regional and national standpoint. Within the States' boundaries is 9 percent of the commercial forest land and 12 percent of the sound wood volume in the South (fig. 1). Although North Carolina boasts only 4 percent of the Nation's forest land and 3 percent of its wood, its forests are so favored by climate and soil that they produce over 7 percent of the total annual growth of saw timber. In 1938 North Carolina had more operating sawmills than any other State, and ranked first in the South and fourth in the Nation in lumber production.

\section{Forest Description}

As already indicated, the forest cover of North Carolina is predominantly second-growth timber. It is composed of a great variety of tree species, the range of several extending from tidewater to the mountain slopes. Each physiographic region has a definite pattern of forest cover, each differing distinctly and characteristically with respect to age, volume per acre, and cutting history.

\section{Species}

In the Coastal Plain, loblolly pine is the most prevalent species (fig. 14), growing both in pure stands and with cther pines and hardwoods. Black and water tupelo are second in abundance, occuring in swamps and bottom lands throughout the region, particularly in Bertie, Martin, Washington, and Tyrrell Counties southwest of Albemarle Sound. Sweetgum grows best in the bottom lands and is most common north of the Neuse River. Pond pine is localized in the Coastal Plain. It is abundant in the large swamps of Columbus, Brunswick, Bladen, and Pender Counties surrounding Wilmington, as well as in Tyrrell, Dare, and Hyde Counties in the nor theast. Longleat pine is of relatively minor importance, occuring in scattered stands near Wilmington and in a fairly large area of second growth in the sandhills of Richmond, Moore, and Hoke Counties in

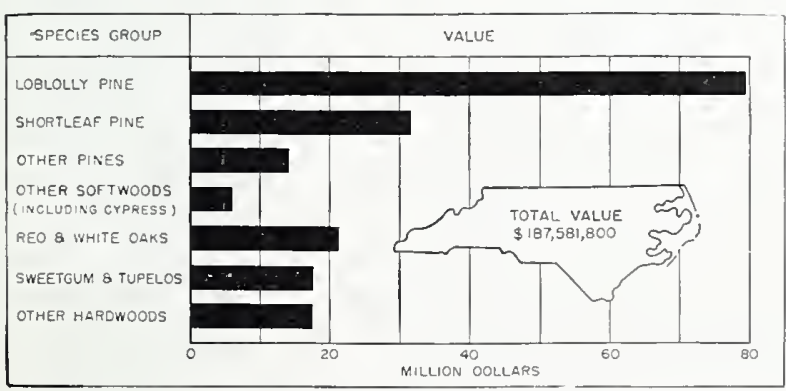

FIgURE 13.-The stumpage value of saw timber in North Carolina, 1938.

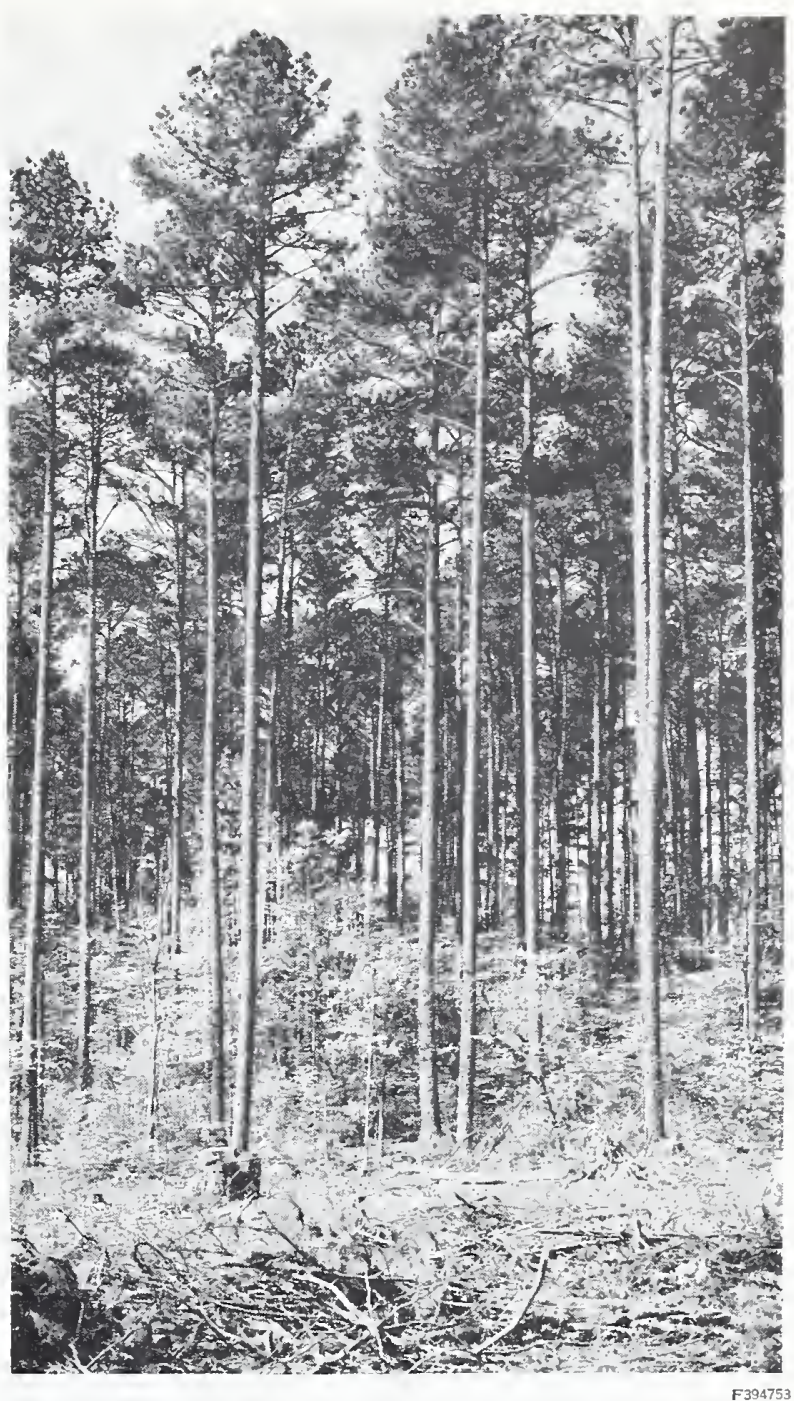

FIGURE 14.-Loblolly pine occupies 26 percent of the forest lund and accounts for 37 percent of the board-foot volume.

the south. The best stands cf "cypress" and Atlantic white-cedar are in Tyrrell County. Red and white oaks are common, growing in mixture with the pines and with other hardwoods throughout the coastal plain.

In the piedmont, the original forest was of mixed hardwoods, chiefly oak and hickory, and some shortleaf pine. After the coming of white men the hardwood forests gave way to cultivated fields, which in turn were frequently abandoned for new clearings and virgin soil. Because the abandoned fields usually restocked to pine, the hard woods have been replaced by old-field pine throughout much of the piedmont. Shortleaf pine appears throughout the area but is most prevalent in that part of the piedmont lying southwest of Winston-Salem, Greensboro, and Durham. Loblolly pine, which extends into the piedmont from the Coastal Plain, is second in importance and is com- 
mon in Warren, Franklin, Wake, Chatham, and Anson Counties. Virginia pine is the leading species in a broad belt across the State paralleling the eastern slopes of the Blue Ridge Mountains. The hardwoods, including yellow poplar, sweetgum, red and white oaks, and hickories occur in scattered mixed stands or associated with the pine throughout most of the piedmont.

The mountain forests are predominantly hardwood, although shortleaf pine is rather common and Tirginia, eastern white, pitch, and Table Mountain pines, eastern hemlock, red spruce, and Fraser fir are present in certain localities. The hardwood species are numerous, but dead chestnut, making up one-fourth of the total volume, is still outstanding in abundance. Practically all of the chestnut has been killed by the chestnut blight which, reaching the mountain forests about 1920, swept through them in a few years. Yellow poplar, one of the more valuable trees, grows in the coves and on the lower moist slopes (fig. 15). There are many species of oak growing on practically all sites, but their quality is much influenced by the kind of site. White oak and northern red oak growing in the coves are excellent timber trees, but on the high, dry ridges they are often of poor form, the best being chestnut oak. Hickories are abundant, but are not considered of very good quality. Red maple grows on practically all sites, basswood and buckeye are frequently associated with yellow poplar in the coves, and black locust is common except at high elevations. Ash, sugar maple, black cherry, and black walnut are valuable species but rather scarce.

Shortleaf pine is common in the Asheville Basin, in Henderson and Cherokee Counties, and, with Virginia pine, on the eastern slopes of the Blue Ridge Mountains. Eastern white pine is most abundant in Caldwell and Wilkes Counties. Pitch and Table Mountain pine are relatively scarce and when found are usually on the upper south and west slopes of the mountains. Eastern hemlock, less abundant than white pine, grows best in the moist soils and the cool, humid climate found in deep stream valleys, in coves, and on north slopes. Red spruce and Fraser fir grow high up on the mountains, particularly in the Great Smoky Mountains National Park and on the Black Mountains in Buncombe and Yancey Counties.

\section{Forest Types}

Tegetal patterns, or forest types, were classified by the Forest Survey on the basis of species composition of stands and the proportion of commercially important dominant trees (table 5). Nearly 30 percent of the cubicfoot volume in the State is loblolly pine. Shortleaf pine ranks next, and black and water tupelo make up an important part of the hardwood stand.

TABLE 5.- Species composition of the principal forest types, expressed in percent of net cubic volume in each type, $19388^{1}$

\begin{tabular}{|c|c|c|c|c|c|c|c|c|c|c|}
\hline \multirow[b]{2}{*}{ Species } & \multicolumn{6}{|c|}{ Softwood types } & \multicolumn{3}{|c|}{ Hardwood types } & \multirow[b]{2}{*}{$\begin{array}{c}\text { All } \\
\text { types }\end{array}$} \\
\hline & $\begin{array}{l}\text { Lohlolly } \\
\text { pine }\end{array}$ & $\begin{array}{c}\text { Shortleaf } \\
\text { pine }\end{array}$ & $\begin{array}{l}\text { Pond } \\
\text { pine }\end{array}$ & $\begin{array}{l}\text { Longleaf } \\
\text { pine }\end{array}$ & $\begin{array}{l}\text { Virginia } \\
\text { pine }\end{array}$ & $\begin{array}{c}\text { White } \\
\text { pine } 8\end{array}$ & $\begin{array}{c}\text { Bottom- } \\
\text { land } \\
\text { hardwood }\end{array}$ & $\begin{array}{c}\text { Upland } \\
\text { hardwood }\end{array}$ & $\begin{array}{c}\text { Cove } \\
\text { hardwood }\end{array}$ & \\
\hline Lohlolly pine.. & $\begin{array}{r}\text { Percent } \\
76.1\end{array}$ & $\begin{array}{r}\text { Percent } \\
2.6\end{array}$ & $\begin{array}{r}\text { Petcent } \\
7.5\end{array}$ & $\begin{array}{r}\text { Percent } \\
8.6\end{array}$ & $\begin{array}{r}\text { Percent } \\
0.3\end{array}$ & Percent & $\begin{array}{r}\text { Percent } \\
6.8\end{array}$ & $\begin{array}{r}\text { Percent } \\
1.4\end{array}$ & Percent & $\begin{array}{l}\text { Percent } \\
25.9\end{array}$ \\
\hline Shortleaf pine ${ }^{3} \ldots$ & 3.9 & 69.3 & .1 & .1 & 16.0 & 2.7 & .2 & 3.3 & 0.1 & 15. 1 \\
\hline Pond pine & .9 &...-- & 83.3 & 4.6 &.--- & -- & .5 & (4) &.-- & 3.8 \\
\hline Longleaf pine- & 1.7 & .1 & 2.4 & 78.8 & --- & $-\cdots$ & .1 & .2 & . & 2.0 \\
\hline Virginia pine & (4) & 3.9 & & & 59.4 & 1.9 & (4) & .4 & .1 & 2.9 \\
\hline White pine & $\ldots$ & .6 & . & $\cdots$ & 1.0 & 27. 2 & - n- & .5 & .3 & .8 \\
\hline Hemlock & $-\cdots-$ & (4) & $\ldots$ & $-\ldots$ & .1 & 22.6 & $\ldots-$ & .5 & 2.8 & .6 \\
\hline Red spruce...... & $-\ldots$ & --- & 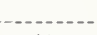 & $\cdots$ & --- & 8.1 &.-- & (1) & (4) & .2 \\
\hline Red cedar & .1 & .6 & (4) & $(4)$ & .3 &.-- & .1 & .1 & & .2 \\
\hline White-cedar & .1 & --- & .7 & $\left({ }^{4}\right)$ & --- & & 3.8 & & & .7 \\
\hline Cypress & .3 & $\cdots$ & .4 & (4) & $-\ldots$ & & 8.5 & (4) & & 1. 6 \\
\hline Sweetgum & 4.8 & 2.0 & .3 & .3 & 1.1 & 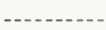 & 15.5 & 2.7 & & 5.3 \\
\hline Tupelos & 3.0 & --- & 3. 0 & .8 & --- &.--- & 32.9 & .4 & 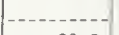 & 7.0 \\
\hline Yellow poplar s & 1.2 & 3.5 & .4 & .2 & 5.5 & 4.4 & 3.3 & 5.4 & 30.2 & 3.4 \\
\hline Red oaks_. & 2.2 & 5. 3 & $(4)$ & 1.3 & 4.5 & 6.7 & 4.5 & 19.6 & 6.9 & 6.2 \\
\hline White oaks & 2.5 & 5.9 & .1 & 1.0 & 5.2 & 5.7 & 2.8 & 22.0 & 3.5 & 6.4 \\
\hline Chestnut & --- & .6 & $\ldots$ & $\cdots$ & .6 & 7.2 & -...- & 20.5 & 22.9 & 4.1 \\
\hline Scruh hardwoods & 6 & .8 & .4 & 3.9 & .6 & 1.3 & 1.3 & 2.3 & 1.6 & 1. 1 \\
\hline \multirow[t]{3}{*}{ Other hardwoods } & 2.6 & 4.8 & 1.4 & .4 & 5.4 & 12.2 & 19.7 & 20.7 & 31.6 & 9.7 \\
\hline & 100.0 & 100.0 & 100.0 & 100.0 & 100.0 & 100.0 & 100.0 & 100.0 & 100.0 & 100.0 \\
\hline & 25.7 & 17.1 & 10.8 & 4.8 & 4. 4 & 1.5 & 12. 2 & 21.6 & 1.9 & 100.0 \\
\hline
\end{tabular}

1 Net cuhic rolume outside bark of sound trces at least 5 inches d. h. h., tops and limhs of hardwoods omitted.

2 White pine, hemlock, and spruce-fir types. $\quad$ Includes small amount of Table Mountain and pitch pine in the mountains.

4 Negligihle. B Includes small amount of hasswood. 


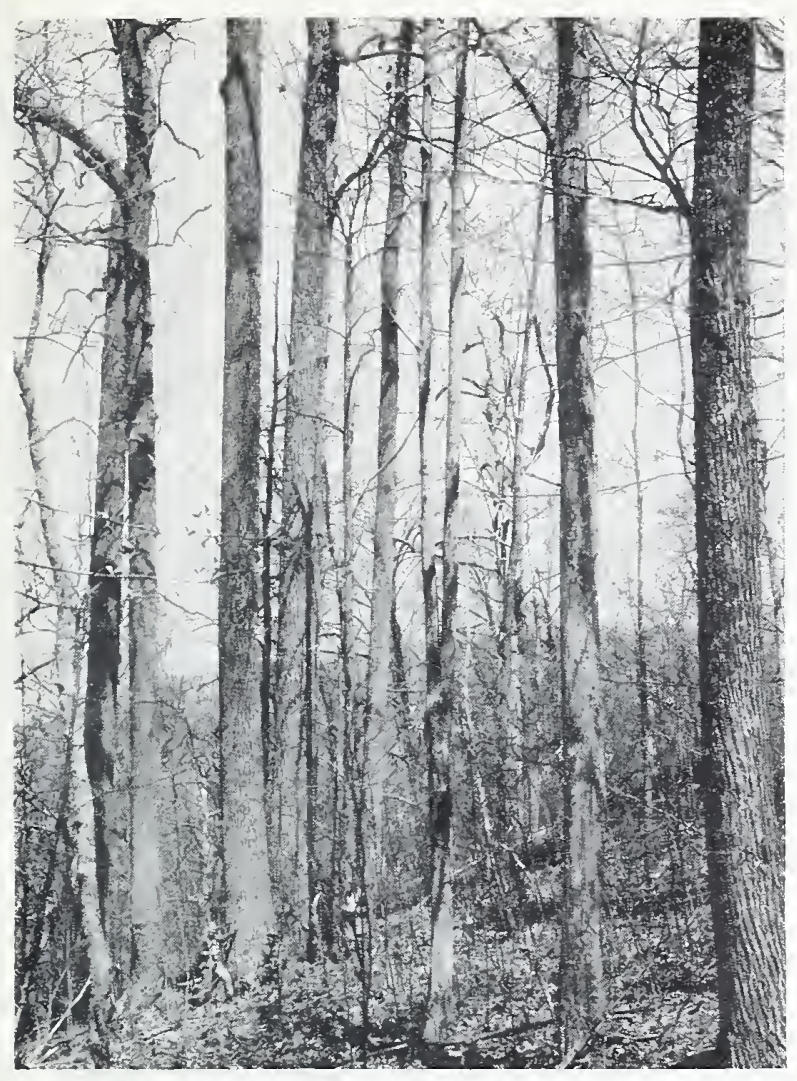

FIGURE 15.-Old-growth yellow poplar growing on a north slope. These trees are 23 to 43 inches in diameter and have a merchantable length of about 70 feet.
The loblolly pine type is most extensive (fig. 16), occupying 26 percent of all the forest land. Though chiefly confined to the Coastal Plain, it also includes about 640,000 acres in the eastern part of the piedmont. Loblolly pine in almost pure stands has restocked abandoned fields and cut-over forest land on three-fifths of the type area, while stands of loblolly pine in mixture usually with sweetgum, black tupelo, yellow poplar, and oaks are common on similar sites as well as along small streams, on poorly drained flats, and at the outer margins of large river bottoms. Shortleaf pine is most frequently an associate along the eastern margin of the piedmont.

The upland hardwoods type, the typical forest cover in the mountains (fig. 17), ranks next to loblolly pine in area. Of the total acreage 55 percent is situated in the mountains, 31 percent in the piedmont, and only 14 percent in the Coastal Plain, including practically all sites and an assortment of species. Nearly two-thirds of the type volume is made up of blight-killed chestnut associated with various oaks. The leading species are chestnut, red oaks, chestnut oak, white oak, hickories, and yellow poplar. In the piedmont and Coastal Plain the upland hardwoods type comprises intermingled stands of pine. The type composition varies widely in both regions with changes in soil, slope, elevation, and moisture conditions. White oaks, red oaks, hickories, yellow poplar, and shortleaf pine make up a large part of the type volume in the piedmont in contrast to white oak, sweetgum, water oaks, loblolly pine, and black tupelo in the Coastal Plain.
Figure 16. - Area of forest types in North Carolina, 1938.

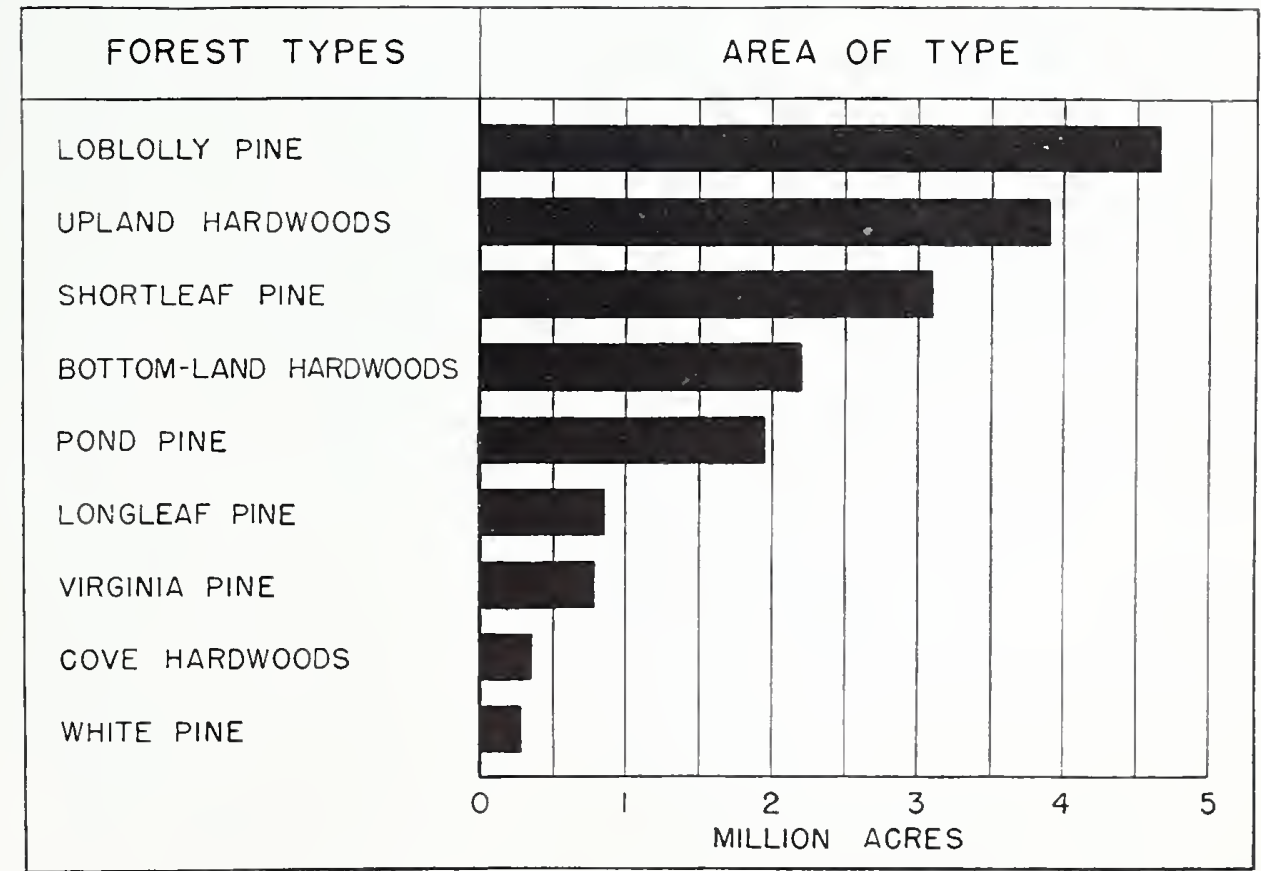




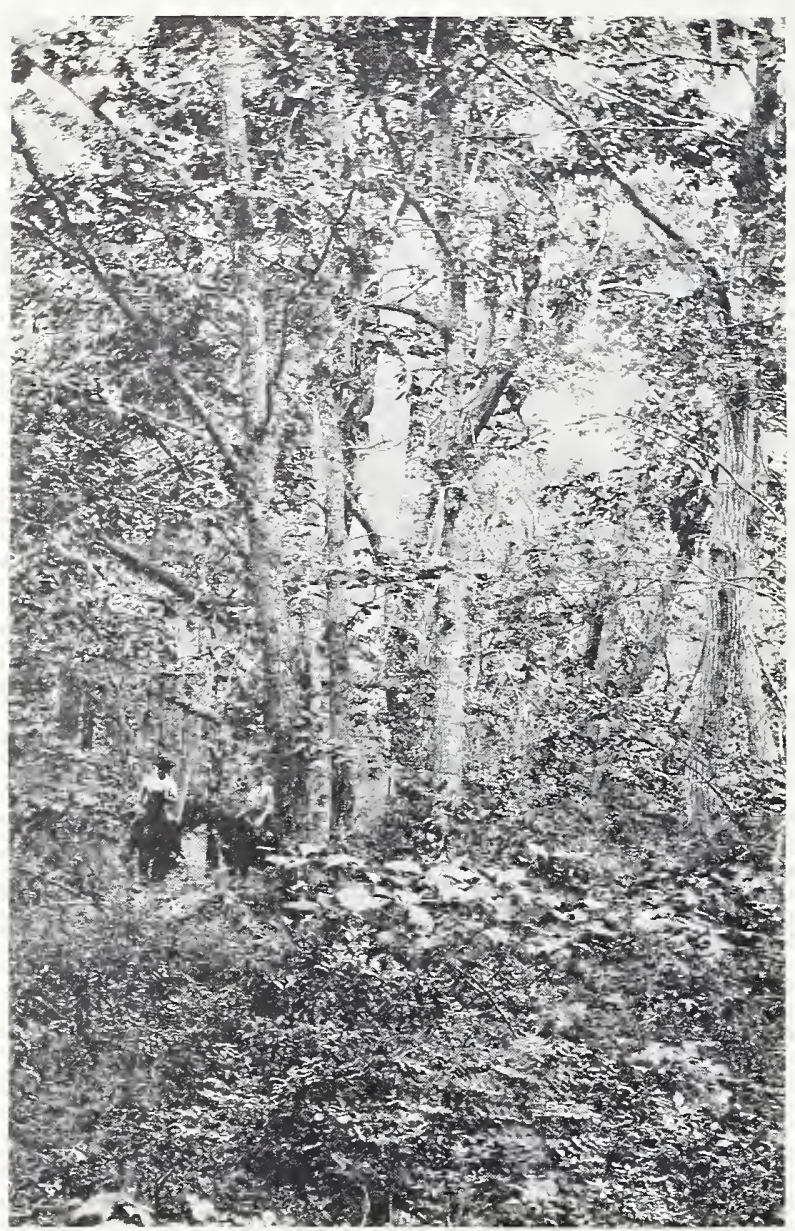

IIGURE 17.- The upland hardwood type, characteristic of the ridge tops, contains a high proportion of chestnut oak, scarlet oak, and dead chestmut. This stand of one-log trees is at 3,500 feet eleoation.

Shortleaf pine is the major forest type in the piedmont (fig. 18). About half of its 2.3 million acres in the piedmont is stocked chiefly with shortleaf pine, generally of old-field origin. On the remaining half the pine is mixed with white, black, southern red, and scarlet oaks, yellow poplar, and other hardwoods. Eastern red cedar often forms a thin understory in these mixed stands. On the eastern margin of the type, loblolly pine merges with the shortleaf and on the western border there is an infiltration of Yirginia pine. In the mountains shortleaf pine is associated chiefly with Virginia pine, red oaks, white oaks, and chestnut. The relatively few scattered stands of this type in the Coastal Plain resemble in composition those in the piedmont.

Most of the bottom-land hardwood type is located in the Coastal Plain, along the rivers, smaller streams, and in the broad swamps. The mixed hardwoods typical of most cf the type contain a high proportion of sweetgum and black and water tupelo; the tupelos often form a distinct subtype. Cypress occurs sparingly in the deeper swamps, mostly along the Roanoke and Chowan Rivers. In Dare, Tyrrell, and Gates Counties, Atlantic white-cedar is found in almost pure stands.

The pond pine type is restricted to the swamps and pocosins of the tidewater area (fig. 19), occupying about one-fifth of the forest land in the Coastal Plain. Stands of pond pine are usually thinly stocked and contain only a small admixture of other species. On some sites the trees are flat-topped and short-boled. In Dare, Tyrrell, and Hyde Counties, particularly, most of the pond pine has been destroyed by severe fires and the land supports only a dense cover of brush with an occasional pond pine tree indicating the original forest cover. Locally these devastated areas are called "lights" or "open ground."

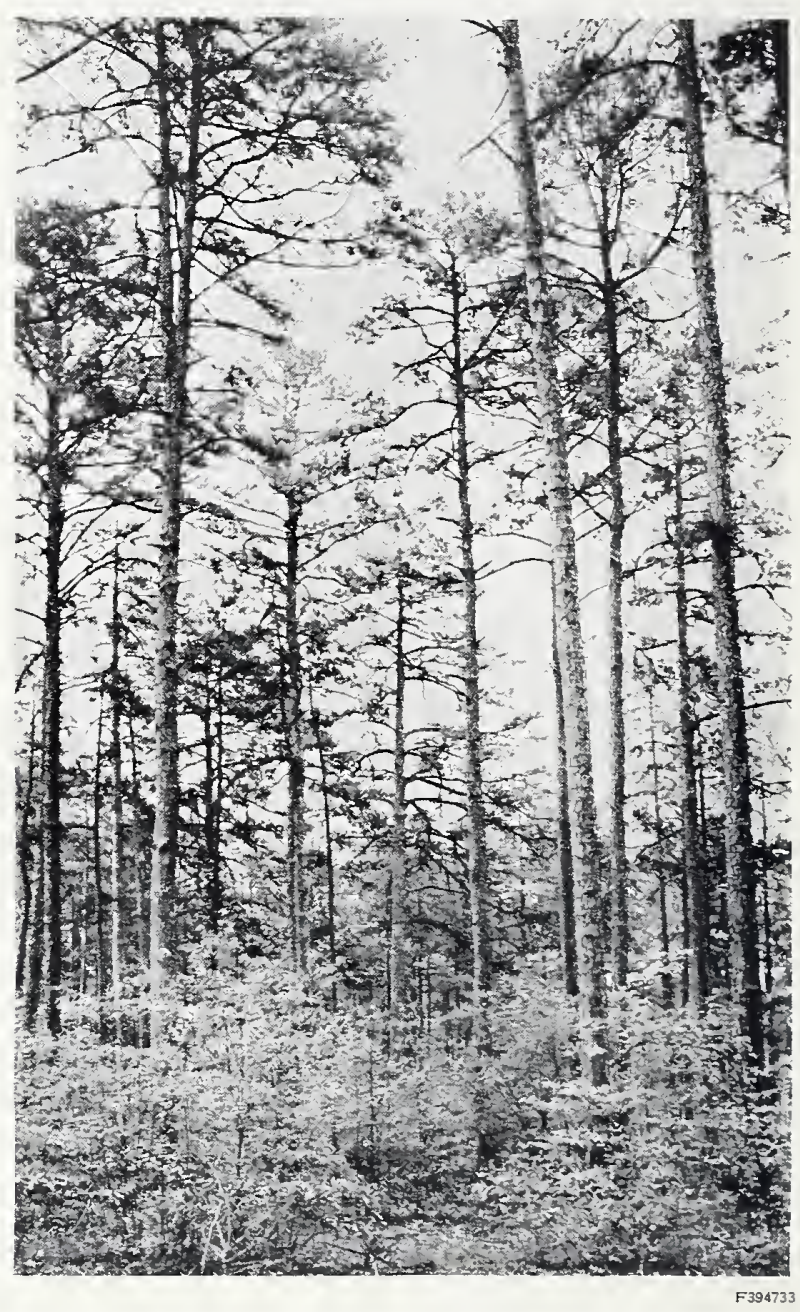

FIGURE 18.-The shortleaf pine type occupies more than 3 million acres, three-fourths of it in the piedmont. This mature old-feld stand is too limby for good-quality saw timber. 


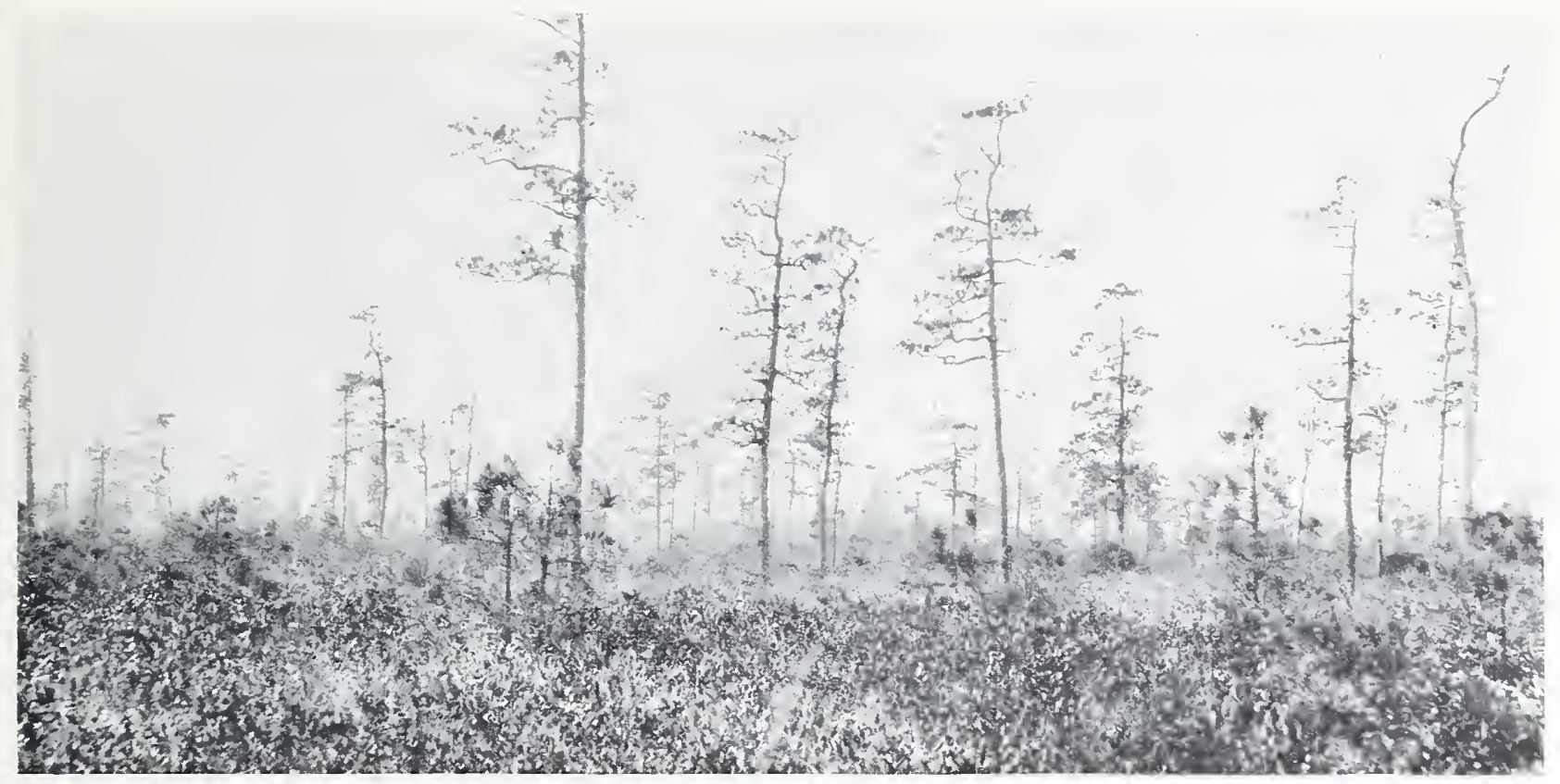

FIgURE 19.- Pond pine in a pocosin in the tidewater area.

On better sites this type produces good quality saw timber.

The longleaf and Virginia pine, cove hardwoods, and white pine types together encompass about 13 percent of the forest land. The longleaf pine type, once very extensive in eastern North Carolina, has been largely replaced by loblolly pine. Scattered stands of merchantable timber and a few patches of young second growth are to be found in the southern tidewater counties, but the cnly considerable area that shows promise of maintaining its type status is located south of Sanford and west of Fayetteville. The Virginia pine type extends from the central piedmont northward and westward to occupy the eastern slopes of the Blue Ridge Mountains. About half of the type is practically pure pine and the rest is a mixture of Virginia and shortleaf pines with oaks, yellow poplar, and
Figure 20.-Old-growth red spruce on the Black Mountains in the Pisgah National Forest.

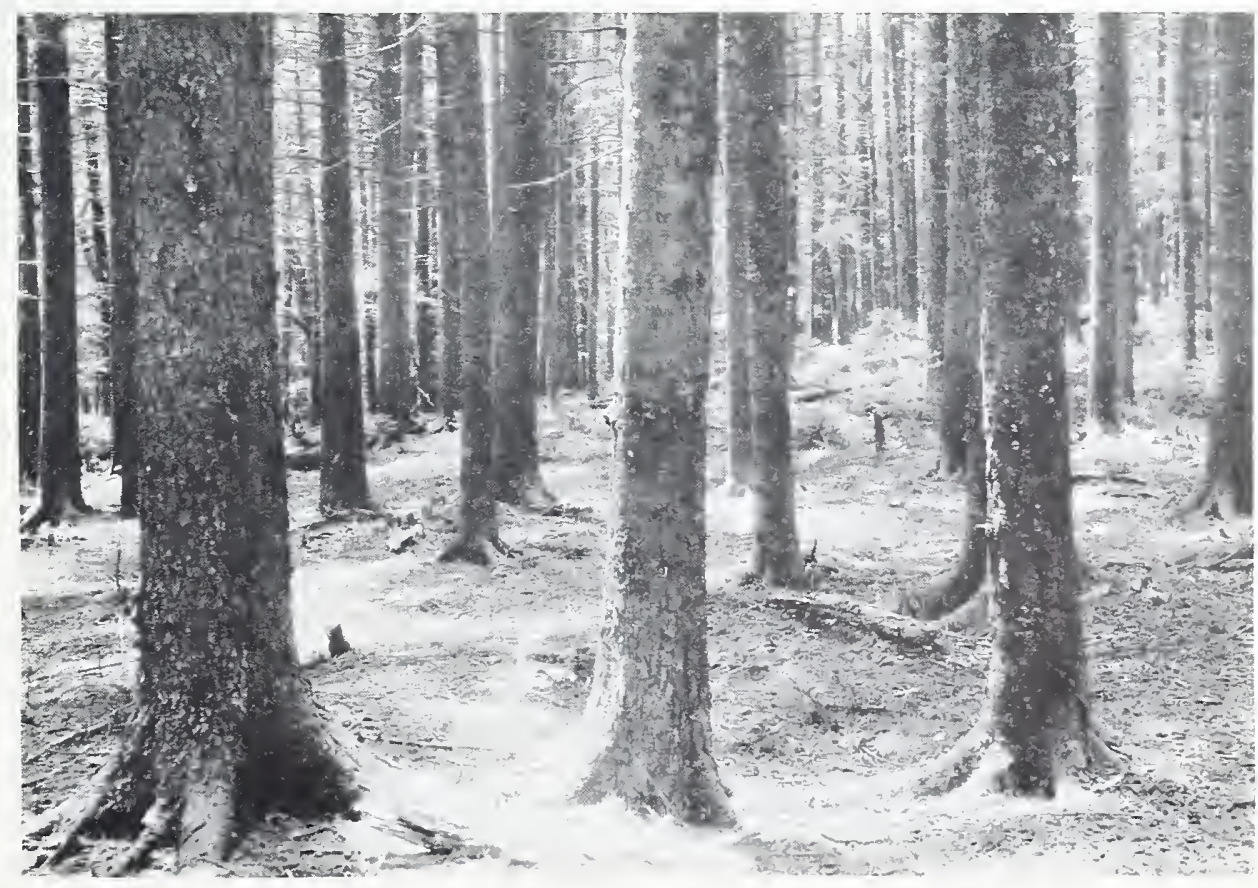


other upland hardwoods. The highly productive cove hardwoods type occupies less than 10 percent of the forest land in the mountains. It includes the beech-birch-maple forest of the upper moist slopes, together with hardwoods growing in the coves, of which yellow poplar is the leading species and basswood, northern red oak, hickory, hemlock, birch, ash, buckeye, and dead chestnut are commonly associates. Abandoned fields in this type have often restocked almost entirely to yellow poplar. The white pine type is scattered throughout the mountains, but is most abundant on the eastern slopes of the Blue Ridge. The type actually contains only 170,000 acres of eastern white pine, for included in this classification are 81,000 acres of hemlock and 23,000 acres of spruce and fir. Hemlock grows in the coves, on the north slopes, and on the banks of the small mountain streams. The present spruce and fir stands are only remnants of the orginal forest of conifers (fig. 20) that once occupied about 150,000 acres on the upper slopes of the Black, Balsam, Unaka, and Smoky Mountains.

\section{Forest Conditions}

Of the different forest conditions, summarized in table 6 for each physiographic region and the State, uncut old growth is the smallest in area, save for clear cut. Oldgrowth stands are usually 100 years old or more, although occasionally loblolly and shortleaf pine will have the size and quality of virgin timber at a younger age. These are seldom large unbroken stands, but occur in small acreages on farms, scattered patches in second-growth stands, narrow strips along rivers, and less accessible blocks in the tidewater swamps and the mountains. Probably the best indication of its scattered distribution is contained in the cutting records of sawmill operators. Data obtained in 1940 from operators who cut 33 different tracts of virgin timber in various parts of the State show that the smallest tract cut was 2.5 acres and the largest 1,200 acres. Half of them were less than 26 acres in size. Most of the few large blocks of old growth that remain are in the mountains and the Coastal Plain.

TABLE 6.-Distribution of forest area by forest condition and physiographic region, 1938

\begin{tabular}{|c|c|c|c|c|c|c|c|c|}
\hline Forest condition & \multicolumn{2}{|c|}{ Coastal plain } & \multicolumn{2}{|c|}{ Piedmont } & \multicolumn{2}{|c|}{ Mountain region } & \multicolumn{2}{|c|}{ All regions } \\
\hline $\begin{array}{l}\text { Old growth: } \\
\text { Uncut } \\
\text { Partly cut }\end{array}$ & $\begin{array}{r}1.000 \text { acres } \\
461.6 \\
799.3\end{array}$ & $\begin{array}{r}\text { Percent } \\
4.8 \\
8.3\end{array}$ & $\begin{array}{r}1,000 \text { acres } \\
107.1 \\
357.2\end{array}$ & $\begin{array}{r}\text { Percent } \\
2.1 \\
7.2\end{array}$ & $\begin{array}{r}1,000 \text { acres } \\
146.0 \\
240.5\end{array}$ & $\begin{array}{r}\text { Percent } \\
4.1 \\
6.8\end{array}$ & $\begin{array}{r}1,000 \text { acres } \\
714.7 \\
1,397.0\end{array}$ & $\begin{array}{r}\text { Percent } \\
4.0 \\
7.7\end{array}$ \\
\hline Total & $1,260.9$ & 13.1 & 464.3 & 9.3 & 386.5 & 10.9 & $2,111.7$ & 11.7 \\
\hline $\begin{array}{l}\text { Second growth, sawlog size: } \\
\text { Uncut } \\
\text { Partly cut }\end{array}$ & $\begin{array}{l}2,329.1 \\
1,780.5\end{array}$ & $\begin{array}{l}24.3 \\
18.6\end{array}$ & $\begin{array}{r}1,242.7 \\
887.1\end{array}$ & $\begin{array}{l}25.0 \\
17.9\end{array}$ & $\begin{array}{l}838.2 \\
454.2\end{array}$ & $\begin{array}{l}23.7 \\
12.8\end{array}$ & $\begin{array}{l}4,410.0 \\
3,121.8\end{array}$ & $\begin{array}{l}24.4 \\
17.2\end{array}$ \\
\hline Total & $4,109.6$ & 42.9 & $2,129.8$ & 42.9 & $1,292.4$ & 36.5 & 7. 531.8 & 41.6 \\
\hline $\begin{array}{l}\text { Second growth, under sawlog size } \\
\text { Reproduction } \\
\text { Clear-cut }\end{array}$ & $\begin{array}{r}3,111.0 \\
842.2 \\
266.1\end{array}$ & $\begin{array}{r}32.4 \\
8.8 \\
2.8\end{array}$ & $\begin{array}{r}2,180.4 \\
189.4 \\
4.2\end{array}$ & $\begin{array}{r}43.9 \\
3.8 \\
.1\end{array}$ & $\begin{array}{r}1,732.8 \\
107.6 \\
24.5\end{array}$ & $\begin{array}{r}48.9 \\
3.0 \\
.7\end{array}$ & $\begin{array}{r}7.024 .2 \\
1,139.2 \\
294.8\end{array}$ & $\begin{array}{r}38.8 \\
6.3 \\
1.6\end{array}$ \\
\hline All conditions - & $9,589.8$ & 100.0 & $4,968.1$ & 100.0 & $3,543.8$ & 100.0 & $18,101.7$ & 100.0 \\
\hline
\end{tabular}

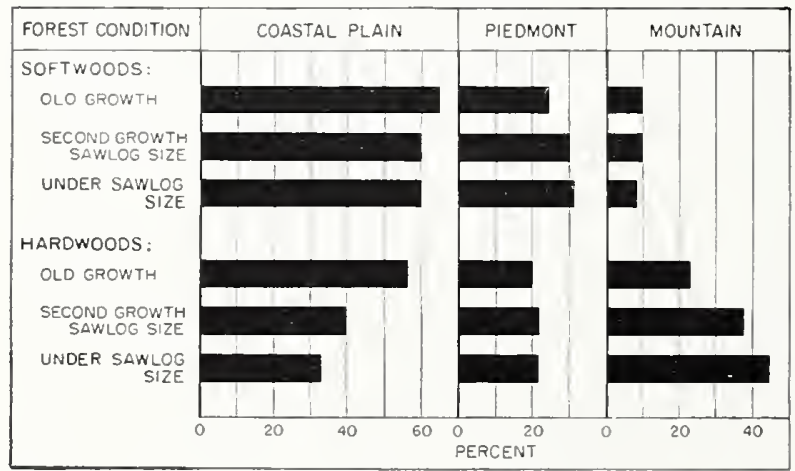

F1GURE 21.-Distribution of forest area by forest condition and physiographic region, 1938, reproduction and clear cut being included in "Under sawlog size."
About two-thirds of the old growth, including a large part of the area in the longleaf pine, Virginia pine, and upland hardwood types, has been cut over for select species or sizes. In the piedmont many such upland hardwood stands now contain only low-quality species and timber More than one-third of all the old growth is in the bottomland hardwoods type (table 7), chiefly confined to the Coastal Plain. Much of this old growth is black and water tupelo, which were unmarketable in the early days of logging. Throughout the State the area of old-growth pine is small compared to the total area of pine types in all the physiographic regions of the State (fig. 21). In contrast, old-growth timber makes up almost 30 percent of the hardwood type in the Coastal Plain and over 12 percent in the mountains. 
TABLE 7.-Distribution of forest area by forest condition and type, 1938

\begin{tabular}{|c|c|c|c|c|c|c|c|c|c|c|}
\hline Forest condition & $\begin{array}{l}\text { Lotilolly } \\
\text { pine }\end{array}$ & $\begin{array}{c}\text { Shortleaf } \\
\text { pine }\end{array}$ & $\begin{array}{l}\text { Pond } \\
\text { pine }\end{array}$ & $\begin{array}{l}\text { Longleaf } \\
\text { pine }\end{array}$ & $\begin{array}{l}\text { Virginia } \\
\text { pine }\end{array}$ & $\begin{array}{l}\text { White } \\
\text { pine? }\end{array}$ & $\begin{array}{c}\text { Upland } \\
\text { hardwoods }\end{array}$ & $\begin{array}{l}\text { Bottom- } \\
\text { land hard- } \\
\text { woods }^{3}\end{array}$ & All $t$ & zpes \\
\hline \multicolumn{11}{|l|}{ Sawlog size: } \\
\hline old growth: & Acres & Acres & Acres & Acres & Acres & Acres & Acres & Acres & Acres & Percent \\
\hline Uneut.... & 92,200 & 49,600 & 98,600 & 6,500 & 2,500 & 31,000 & 144,300 & 290,000 & 714,700 & 4. 0 \\
\hline Partly cut & 213,500 & 132,600 & 57,000 & 65,800 & 7,500 & 19,500 & 405,300 & 495,800 & $1,397,000$ & 7.7 \\
\hline \multicolumn{11}{|l|}{ Second growth: } \\
\hline Uncut & $1,472,600$ & 939,300 & 401,400 & 94,300 & 225,100 & 90,500 & 624,900 & 561,900 & $4,410,000$ & 24.4 \\
\hline Partly cut_..-- & $1,436,100$ & 596,900 & 93,700 & 45,800 & 91,800 & 58,700 & 498,100 & 300,700 & $3,121,800$ & 17.2 \\
\hline Total ... & $3,214,400$ & $1,718,400$ & 650,700 & 212,400 & 326,900 & 199,700 & $1,672,600$ & $1,648,400$ & $9,643,500$ & 53.3 \\
\hline \multicolumn{11}{|l|}{ Under sawlog size: } \\
\hline Reproduction - & 174,300 & 113,200 & 388,300 & 118,800 & 71,100 & 3,200 & 94,000 & 176,300 & $1,139,200$ & 6.3 \\
\hline Clear-cut_-_. & 44,800 & 800 & 157,800 & 46,300 & 800 & 3,300 & 22,200 & 18,800 & 294,800 & 1. 6 \\
\hline Total_- & $1,436,000$ & $1,380,100$ & $1,306,200$ & 650,700 & 469,400 & 74,200 & $2,227,000$ & 914,600 & $8,458,200$ & 46. 7 \\
\hline All conditions. & $4,650,400$ & $3,098,500$ & $1,956,900$ & 863,100 & 796,300 & 273,900 & $3,899,600$ & $2,563,000$ & $18,101,700$ & \\
\hline
\end{tabular}

1 These tabulated areas, derived from plot data, do not correspond exactly to the hroad areas delineated on the forest type map at the end of this publication, since they allow for local variations in forest cover and interspersed agricultural land not shown on the map.

I Includes white pine, spruce-fir, and hemlock types. $\quad{ }^{3}$ Includes 351,200 acres of cove hardwoods type.

The 7.5 million acres of sawlog-size second growth constitutes the main immediate source of saw timber for the wood-using industries. Fifty-five percent of this acreage is located in the Coastal Plain, 28 percent in the piedmont, and 17 percent in the mountains. Almost two-fifths of the merchantable second growth is loblolly pine. Light cutting has removed part of the volume on about 40 percent of the total area, but in the loblolly pine type, which is utilized more intensively, half of the area has been partly cut. Each year a considerable area of under-sawlog-size trees comes into the sawlog class, but since half a million acres of sawlog timber is cut annually, the ratio between the two areas is not likely to favor the sawlog class at any time.

Young second growth, over 1 inch in diameter but less than sawlog size, occupies almost 40 percent of the forest land. This class of timber occupies a high proportion of the area in shortleaf pine, longleaf pine, Virginia pine, and upland hardwood types.

Of the 1.1 million acres bearing seedlings, about onethird is in the pond pine type. In general, the trees are apt to be poorly spaced and of undersirable species. More than half of the area classified as clear-cut and not restocking (fig. 22) is in the pond pine pocosins.

\section{Age of Stands}

The pine stands of old-field origin are usually even-aged. Forest-grown stands commonly contain several age classes, save where an even-aged stand may have come in after a heavy cutting. Whereas most old-growth pine is 80 years and more, most of the second-growth sawlog pine ( 9 inches d. b. h.) is 30 to 60 years and the under-sawlog size pine less than 35 years old (table 8). Dominant trees on good sites will grow much faster.

Stands of hardwood normally contain reproduction, saplings, and merchantable trees, the relative proportion of each varying with the forest condition. The occasional even-aged hardwood forest consists usually of second growth established after a heavy cutting, sweetgum or yellow poplar growing on abandoned fields, second-growth black and water tupelo in the coastal swamps, or virgin timber without an understory of young growth. As a rule, the hardwoods grow more slowly than pine and most species do not attain sawlog size (13 inches d. b. h.) under 60 years (table 8 ). The old-growth stands range from 100 to 350 years.

TABLE 8.- - Ige of average trees of selected species on average site, by diameter class

\begin{tabular}{|c|c|c|c|c|c|}
\hline \multirow{2}{*}{ Species } & \multicolumn{5}{|c|}{ Diameter at breast height (inches) } \\
\hline & 4 & 6 & 8 & 10 & 12 \\
\hline & Years & Years & Years & Years & Years \\
\hline Loblolly pine & 19 & 26 & 33 & 39 & 4 \\
\hline Virginia pine & 20 & 27 & 33 & 39 & 44 \\
\hline Yellow poplar & 22 & 27 & 33 & 39 & 46 \\
\hline Shortleat pine & 24 & 31 & 38 & 45 & 52 \\
\hline Sweetgum & 24 & 31 & 39 & 50 & 61 \\
\hline Pond pine....... & 19 & 28 & 39 & 51 & 64 \\
\hline Water oak..... & 29 & 37 & 47 & 58 & 71 \\
\hline Southern red oak & 29 & 38 & 49 & 61 & 74 \\
\hline Black oak ...... & 31 & 39 & 50 & 62 & 78 \\
\hline scarlet oak.... & 31 & 40 & 51 & 64 & 76 \\
\hline Forthern red oak & 34 & 43 & 54 & 67 & 85 \\
\hline Black tupelo . .... & 36 & 47 & 60 & 73 & 86 \\
\hline Chestnut oak. . & 31 & 40 & 53 & 69 & $8 i$ \\
\hline White oak & 33 & 45 & 58 & 72 & $8 i$ \\
\hline
\end{tabular}




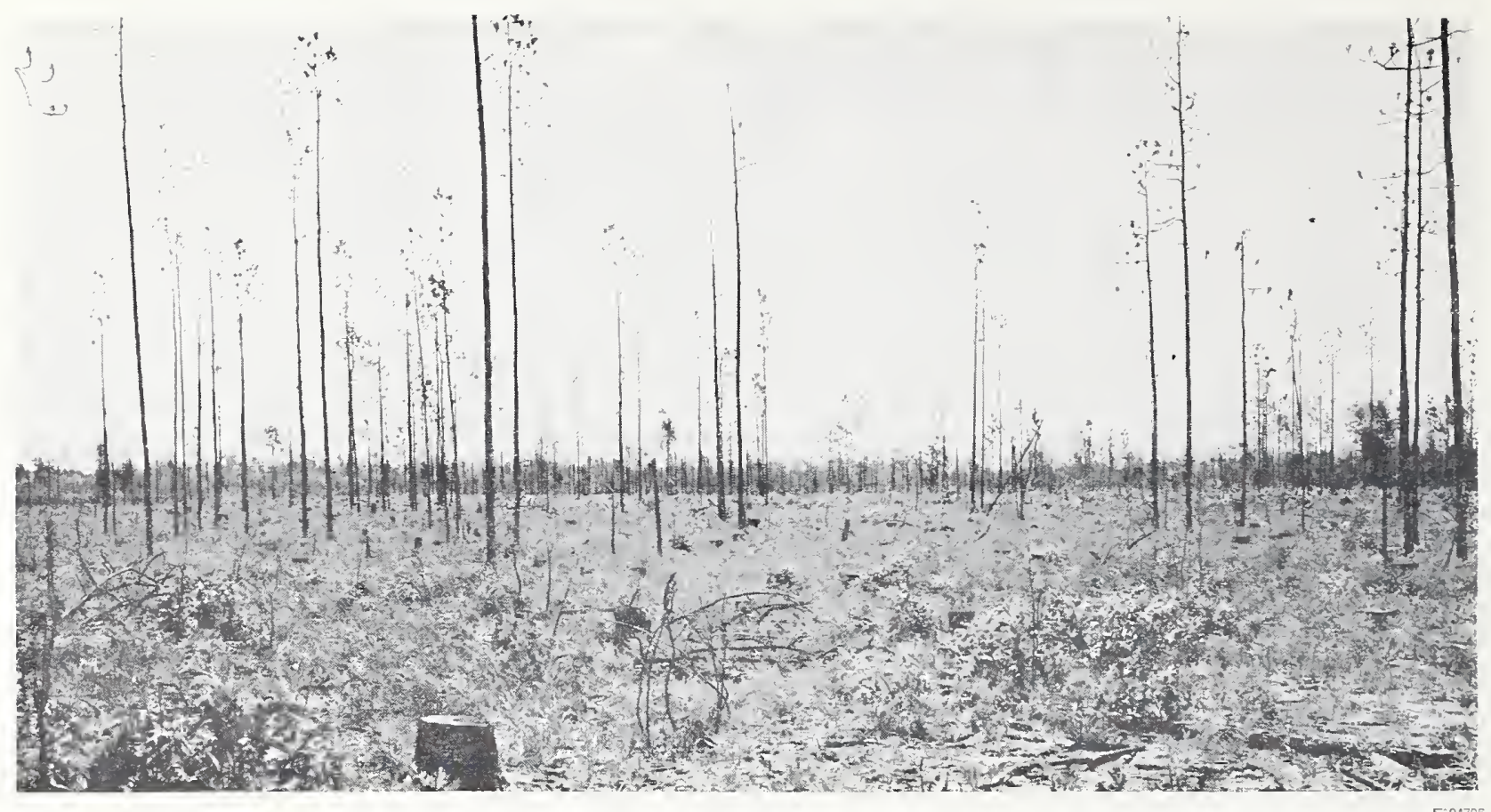

FIGCre 22.-Poles, sawiogs, and pulpwool wire cut fiom this land and it was then burned. Forturately only a small part of North Carolina's forest land is devastated so thoroughly.

To produce an annual sustained yield of wood a forest should be made up of a series of timbered areas of equal froductivity varying in age by equal intervals from the youngest to the oldest age class. The proportionate area required in each age class varies primarily with the length of the rotation, but it is affected also by financial considerations, the need for timber, kind of material being grown, species, and site quality. In general, pine sawlogs of minimum size can be grown in 30 to 40 years in North Carolina, but it takes close to 80 years to produce high-quality saw timber. The minimum rotation necessary to grow hardwood saw timber is 80 years for most species; yellow poplar

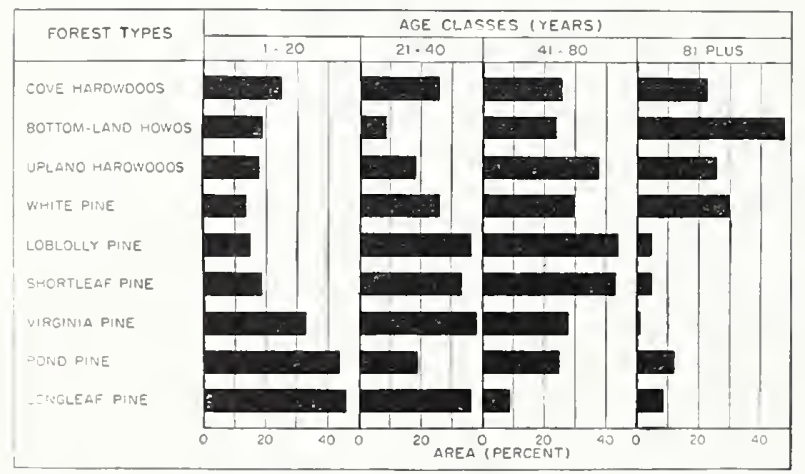

FIGURE 23.-Proportionate distribution of forest type areas by age class, 1938. and sweetgum, however, eften grow to minimum sawlog size in 60 years.

Most of the forest types in the State will provide a fairly continuous production of saw timber, although few have a balanced arrangement of age classes (fig. 23). The longleaf and pond pine types have proportionately too large an area in the youngest age class. The distribution in the Virginia pine type seems about right for the production of pulpwood and low-grade saw timber. Approximately half the area in the shortleaf and loblolly pine types is stocked with stands of saw-timber age. Although stands over 80 years occupy only 5 percent of each type area, this is not a serious defect; these species will produce goodquality saw timber on an 80-year rotation. If the hardwood types were operated on a 120-year rotation, which is reasonable, the present age-class distribution would be fairly satisfactory.

Site Quality

Like cultivated soils, forest soils have different degrees of fertility and vary in productivity. Many people believe that all land too poor for agriculture is suitable for timber production, but in actuality, part of the forest land in North Carolina will grow only inferior crops of trees.

Next to soil, the productivity of forest land is influenced most by climate. The combined effect of soil, climate, 
and other factors is reflected in the quality of the site. Site quality is measured in several ways-most commonly for southern pine in the height of average dominant trees at 50 years of age. This criterion differs for different species. In table 9 the area of each of the pine types except pond pine has been classified as to site quality on the basis of the following minimum heights of average dominant trees:

Loblolly and eastern white pine: Feet Good .................................. 80

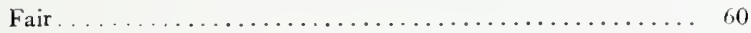

Poor ..................................... 50

Shortleaf, longleaf, and Virginia pine:

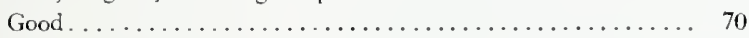

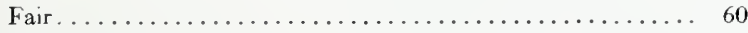

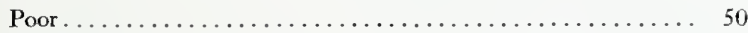

The area supporting hardwood types was classified as good, fair, or poor, using soil and moisture conditions, topographic aspect, and merchantable height and form of trees as indicators of site quality.

TABLE 9.- Proportion of forest-type areas in 3 site classes, 19381

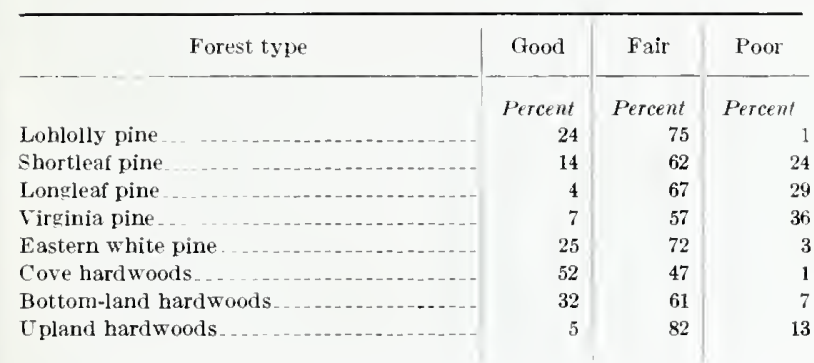

1 The area in the pond pine ty pe was not classified, but a large part of it is of poor site quality.

The implications of this classification can be briefly summarized. Practically all of the land stocked with loblolly or white pine will grow stands of tall, well-formed, commercial timber. About one-fourth of the land in the shortleaf and longleaf pine types is of poor site quality and the trees grown on this land will be short-boled and of slow growth. Site quality is still poorer in the Virginia pine type and about one-third of the land will produce only trees of doubtful saw-timber value. Most of the hardwoods grow on fair to good sites and only a small proportion of the land produces mature trees averaging less than two merchantable logs. All together, about 2 million acres of forest land, exclusive of the pond pine type, are of poor site quality. In general, timber production on this acreage will yield low returns.

\section{Stocking}

An exhaustive study of the degree of stocking on the 18 million acres of forest land in North Carolina was impossible with available personnel and funds. As an alternative, an intensive study was made of stocking in the loblolly pine type, which occupies 4.6 million acres. The stocking classification was based on the uncut and unburned forest plots tallied in the loblolly pine type. Using total basal area of all trees over 1 inch $d$. b. h. and the average tree diameter as criteria, a stocking class was assigned to each plot. The next step was to classify the burned-over and partially cut plots also; thus a total of 3,550 forest plots in all condition and age classes of the loblolly pine type were classified. The total type area was then divided into stocking classes on the basis of plot distribution. In general, class I represents full stocking, classes II and III are satisfactory, and classes $I V, V$, and VI are progressively unsatisfactory.

$\mathrm{T}_{\mathrm{ABLE}}$ 10.- Stocking classification of forest land in the lablolly pine type

\begin{tabular}{|c|c|c|c|c|c|c|c|}
\hline \multirow{2}{*}{ Forest condition } & \multicolumn{6}{|c|}{ Stocking class 1} & \multirow{2}{*}{ All classes } \\
\hline & I & II & III & IV & V & VI & \\
\hline $\begin{array}{l}\text { Sawlog size: } \\
\text { Old growth } \\
\text { Second growth }\end{array}$ & $\begin{array}{l}\text { Acres } \\
23,400 \\
201,300\end{array}$ & $\begin{array}{l}\text { Acres } \\
19,400 \\
228,900\end{array}$ & $\begin{array}{r}\text { Acres } \\
56,900 \\
435,900\end{array}$ & $\begin{array}{l}\text { Acres } \\
79,700 \\
506,800\end{array}$ & $\begin{array}{l}\text { Acres } \\
52,400 \\
609,200\end{array}$ & $\begin{array}{l}\text { Acres } \\
73,900 \\
926,600\end{array}$ & $\begin{array}{l}\text { Acres } \\
305,700 \\
2,908,700\end{array}$ \\
\hline Total & 224,700 & 248,300 & 492,800 & 586,500 & 661,600 & $1,000,500$ & $3,214,400$ \\
\hline $\begin{array}{l}\text { Under sawlog size: } \\
\text { Second growth } \\
\text { Reproduction } \\
\text { Clear-cut }\end{array}$ & 90,300 & 59,400 & $\begin{array}{r}63,000 \\
-\end{array}$ & $\begin{array}{r}144,800 \\
6,800\end{array}$ & $\begin{array}{r}242,800 \\
12,400\end{array}$ & $\begin{array}{r}616,600 \\
155,100 \\
44,800\end{array}$ & $\begin{array}{r}1,216,910 \\
174,300 \\
44,800\end{array}$ \\
\hline Total. ..... & 90,300 & 59,400 & 63,000 & 151,600 & 255,200 & 816,500 & 1,436 , (Мю \\
\hline All eonditions..... & $\begin{array}{r}\quad 315,000 \\
\begin{array}{r}\text { Percent } \\
6.8\end{array}\end{array}$ & $\begin{array}{r}\text { 307, } 700 \\
\text { Percent } \\
6.6\end{array}$ & $\begin{array}{l}555,800 \\
\text { Percent } \\
11.9\end{array}$ & $\begin{array}{r}\text { 738, } 100 \\
\text { Percent } \\
15.9\end{array}$ & $\begin{array}{r}\text { 916, } 800 \\
\text { Percent } \\
19.7\end{array}$ & $\begin{array}{l}\text { 1,817, } 000 \\
\text { Percent } \\
39.1\end{array}$ & $\begin{array}{l}\text { 4, 650, } 400 \\
\text { Percent } \\
100.0\end{array}$ \\
\hline
\end{tabular}

1 Classes I, II, and III represent, in general, satisfactory stocking; the others, less than satisfactory. 
Only a small part of the forest land ( 7 percent) is fully stocked with desirable trees, and only 1.2 million acres, 25 percent, can be considered well stocked. Although the timber stands are too dense for satisfactory growth on some areas, most of the land can support more trees per acre and so produce larger annual yields of better-quality wood. In some cases, the forest land is fully occupied by well-spaced trees, which are, however, of species unmerchantable at present. Three-fourths of the loblolly pine land is in the lower three stocking classes (table 10). Of the whole, only about 30 percent of the saw-timber area and only 15 percent of the area supporting under-sawlogsize stands are rated as satisfactorily stocked.

Board-foot volumes did not enter into the stocking classification, but they help to illustrate the practical meaning of differences in stocking. In table 11 the volume per acre is the average of all uncut and unburned forest plots in each age and stocking class. It represents the yield that can be expected from stands under fire protection in the different stocking classes. Board-foot volumes are present in the younger age classes because of the occurrence of scattered saw-timber trees. If all the loblolly stands were included, average volumes would be less in every class because of partial cutting and fire loss.

TABLE 11.-Board-foot volume ${ }^{1}$ per acre of uncut, unburned loblolly pine stands by age and stocking classes on the average site

\begin{tabular}{|c|c|c|c|c|c|c|}
\hline \multirow{2}{*}{ Age class years } & \multicolumn{6}{|c|}{ Stocking elass 2} \\
\hline & I & II & III & IV & $r$ & VI \\
\hline 10. & 760 & 700 & 640 & 560 & 400 & 240 \\
\hline 20 & 3,560 & 3,220 & 2,760 & 2.130 & 1,300 & 820 \\
\hline $30 \ldots$ & 7,940 & 6,760 & 5,440 & 3,900 & 2,560 & 1,740 \\
\hline $40 \ldots$ & 11,120 & 9,360 & 7,280 & 5,220 & 3,600 & 2,580 \\
\hline 50 & 13,700 & 11,280 & 8,880 & 6.500 & 4,560 & 3,320 \\
\hline $60 \ldots$ & 15,740 & 13,000 & 10,360 & 7,760 & 5,560 & 4,080 \\
\hline $70 \ldots$ & 17,520 & 14,600 & 11,760 & 9,020 & 6,620 & 4,900 \\
\hline 80 & 19. 240 & 16,100 & 13,120 & 10,240 & 7,680 & 5,780 \\
\hline $90 \ldots$ & 20,880 & 17,560 & 14,420 & 11,440 & 8,760 & 6,680 \\
\hline 100 & 22,320 & 19,000 & 15,720 & 12,640 & 9,840 & 7,680 \\
\hline
\end{tabular}

\footnotetext{
1 All species included, volumes by the International 1 -inch log rule.

2 Classes I, II, and III represent, in general, satisfactory stocking; the others, less than satisfactory.
}

The stocking classification did not take into account reproduction less than 1 inch in diameter. Accordingly, the 3.5 million acres of loblolly pine land in the lower three stocking classes was further classified as to the number of well-established pine and hardwood seedlings per acre (table 12). The areas bearing more than 600 seedlings per acre should, with fire protection, become reasonably productive, but much of the land with fewer than 200 seedlings per acre, and some of that in the intermediate class, will require interplanting for early attain- ment of good stocking. A large part of the land with fewer than 600 seedlings per acre supports enough large trees to provide seed, and will not need planting.

$\mathrm{T}_{\mathrm{ABLE}}$ 12.-Poorly stocked areas 1 in the loblolly pine type, by forest condition and number of seedlings per acre ${ }^{2}$

[In thousands of acres; i.e.; 000 omitted]

\begin{tabular}{|c|c|c|c|c|c|c|}
\hline \multirow{2}{*}{ Forest condition } & \multirow{2}{*}{$\begin{array}{l}\text { Total } \\
\text { area }\end{array}$} & \multicolumn{2}{|c|}{$601+$ seedlings } & \multicolumn{2}{|c|}{$\begin{array}{l}200-600 \\
\text { seedlings }\end{array}$} & \multirow{2}{*}{$\begin{array}{c}0-199 \\
\text { seed- } \\
\text { lings } \\
\text { all } \\
\text { species }\end{array}$} \\
\hline & & Pine & $\begin{array}{l}\text { Hard- } \\
\text { wood }\end{array}$ & Pine & $\begin{array}{l}\text { Hard- } \\
\text { wood }\end{array}$ & \\
\hline \multicolumn{7}{|l|}{ Sawlog size: } \\
\hline Old growth. & 206.0 & 16.2 & 64.8 & 6.3 & 48.9 & 69.8 \\
\hline Second growth. & $2,042.6$ & 158.2 & 736.9 & 87.8 & 526.3 & 533.4 \\
\hline Total_- & $2,248.6$ & 174.4 & 801.7 & 94.1 & 575.2 & 603.2 \\
\hline \multicolumn{7}{|l|}{ Under sawlog size: } \\
\hline Second growth. & 1.004 .2 & 106.3 & 299.8 & 93.4 & 209.4 & 295.3 \\
\hline Reproduction.- & 174.3 & 35.6 & 43.4 & 33.7 & 18.1 & 43.5 \\
\hline Clear-cut & 44.8 & & & & -... & 44.8 \\
\hline \multirow[t]{2}{*}{ Total... } & $1,223.3$ & 141.9 & 343.2 & 127.1 & 227.5 & 383.6 \\
\hline & $3,471.9$ & 316.3 & $1,144.9$ & 221.2 & 802.7 & $986 . \mathrm{s}$ \\
\hline All conditions & $\begin{array}{r}\text { Percent } \\
100.0\end{array}$ & $\begin{array}{c}\text { Percent } \\
9.1\end{array}$ & $\begin{array}{c}\text { Percent } \\
33.0\end{array}$ & $\begin{array}{c}\text { Percent } \\
6.4\end{array}$ & $\begin{array}{c}\text { Percent } \\
23.1\end{array}$ & $\begin{array}{r}\text { Percent } \\
28.4\end{array}$ \\
\hline
\end{tabular}

1 In classes IV, $V$, and VI. See p. 25

2 Of major pine and hardwood species.

About 42 percent of the land in stocking classes IV, $\mathrm{V}$, and VI has over 600 seedlings per acre. These seedlings, plus the larger trees present, should equal satisfactory stocking; thus the area in classes I, II, and III will probably increase by 1.5 million acres. It may be concluded that 57 percent of the loblolly pine type is satisfactorily stocked with reproduction and larger trees, but it should be remembered that not all of the growing stands are of desirable species. For example, hardwoods form most of the reproduction on nearly four-fifths of the land that has 200 or more seedlings per acre. In a forest region where wood-using industries depend mainly on pine timber, the possible replacement of the pine by hardwoods deserves attention and, if the necessity arises, remedial action.

\section{Forest Fires}

Forest fires constitute a serious problem because the effects of past fires add to the difficulties of forest management and because constant vigilance is required for adequate fire prevention and suppression. The spring fire season, extending from about February 1 to May 15, corresponds with the period between the cessation of the winter rains and the growth of new foliage, at a time when strong drying winds are frequent. It is usually more 
FIGURE 24.-In the mountain region 28 percent of the sound hardwood volume is in cull trees. The basal fire scars and subsequent decay resulting from forest fires are major causes of cull.

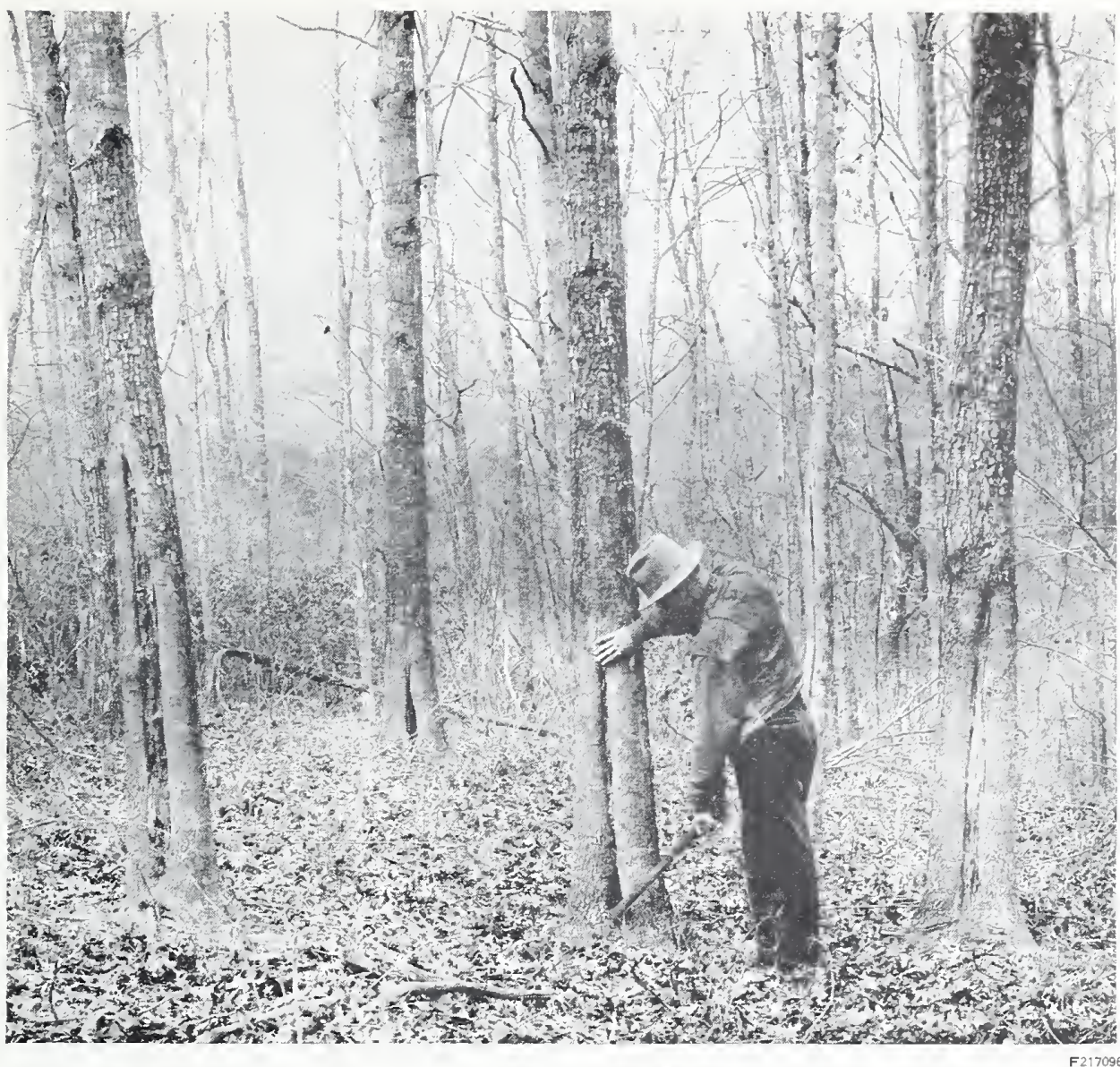

dangerous than the fall season, when the chief hazards are the new-fallen leaves of the hardwoods and the dry grasses and underbrush of the pine forests.

Crown fires are infrequent, occurring only in extremely dry years. Most of the fires burn only the ground litter, young trees, and bases of older stems. Ground fires in the pond pine and white-cedar types along the coast are often difficult to control; they may penetrate the muck soils to a depth of several feet, and deep encircling trenches must be dug to extinguish them.

Fires damage the forest in several ways. In both the pine and hardwood stands reproduction and young trees are killed outright, the proportion of undesirable hardwood sprouts on reproduction areas is increased, and stand composition is often changed for the worse. Basal firescars on hardwoods cause serious losses in volume because many of the scars become infected with wood-decaying fungi. Fire-scarred, partially rotten hardwood trees occupy a large amount of the growing space in the mountain forests (fig. 24) and their elimination is one of the more difficult problems of management.
In spite of the protection afforded private and public forest lands by the fire-control organizations of the North Carolina Division of Forestry, the United States Forest Service, the National Park Service, and the Indian Forest Service, the losses from forest fires are still severe. In the 5-year period from 1935 to 1940 an average of 4,535 fires burned over 426,170 acres per year. The average annual damage amounted to $\$ 757,000$. About two-thirds of the total forested area was under protection and 1.5 percent of this land burned over annually with damage amounting to $\$ 387,000$. In contrast, 3 percent of the unprotected land burned over each year with damage of $\$ 370,000$.

In bad fire years losses are much greater. In 1941 the North Carolina Division of Forestry had 11,823,000 acres under organized protection. The Coastal Plain experienced particularly severe spring fires, which spread over 655,000 acres, 5.5 percent of all State-protected land. In the Coastal Plain protection districts from 8 to 10 percent of the protected acreage was burned. Not counting damage on the national forests and the unprotected private forest land in the piedmont and Coastal Plain, the State-wide loss was $\$ 1,120,000$. 


\section{The Volume of the Forest Resource}

HE estimates of standing timber in the State refer to the volume in all trees 5 inches d. b. h. and larger, including the dead chestnut. Volumes are estimated in three units of measure: Board feet, cords, and cubic feet. ${ }^{5}$

\section{Broad-foot Volume}

In 1938 the saw-timber volume in North Carolina amounted to nearly $4+$ billion board feet, when scaled by the International $1 / 4-$ inch $\log$ rule. This rule closely approximates green-lumber tally and results in materially higher estimates than those obtained by the Doyle rule commonly used in the State. This enormous volume of wood constituted nearly 3 percent of all the saw timber in the United States and about 11 percent of the total stand in the South. Georgia, with 46 billion board feet ${ }^{6}$ is the only State in the South that has more saw timber. Nore than half of North Carolina's saw timber is located in the Coastal Plain (fig. 25).

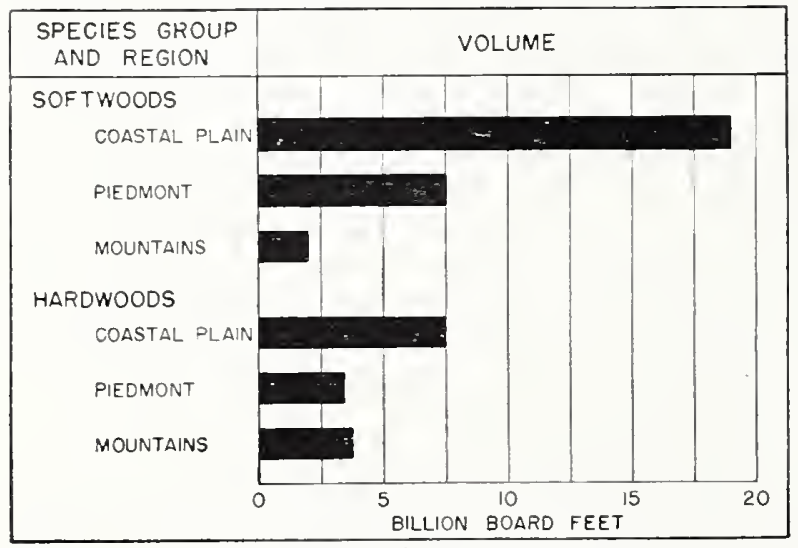

FIGURE 25.-Distribution of board-foot volume (International 1/4-inch rule), 1938.

\footnotetext{
3 Definitions of the three kinds of volume and other terms are given in the appendix, p. 70 .

'Spillers, A. R., and Eldredge, I. F. georgla forest resources and industries. U. S. Dept. Agr. Misc. Pub. 501, 70 pp., illus. 1943.
}

\section{Volume by species}

Two-thirds of the total saw-timber volume is softwood (tables 13 and 38 and fig. 26). Loblolly pine, totaling 16 billion board feet, makes up nearly three-fifths of the softwood volume and is by far the leading species in the State. In the Coastal Plain it accounts for 54 percent of the total saw-timber volume. Shortleaf pine has one-fifth of the softwood volume, ranks second, and in the piedmont constitutes almost half of the saw timber. North Carolina was once famous for its vast stands of longleaf pine, but these have been succeeded on logged land by loblolly pine and at present there is less than a billion board feet of longleaf timber in the State. Pond pine, Virginia pine, and cypress are also important components of the softwood volume. Pond pine is a much disparaged but extensively used species native to the swamps of the Coastal Plain. Its chief virtue is that it will grow into reasonably good saw timber on sites too rigorous for most other species. The 1 billion board feet of cypress occurs in scattered stands in the swamps and along the rivers of the tidewater area. The best stands are in Tyrrell County, along the lower reaches of the Roanoke River, and in the bottom lands near the junction of the Meherrin and Chowan Rivers. Whitecedar is not abundant but a large part of the remaining supply on the Atlantic Coast is located in Tyrrell County and the North Carolina portion of the Dismal Swamp.

The hardwood volume, which is about one-third of the total saw timber, is distributed rather uniformly among the groups of hardwood species. Black and water tupelos combined are the most abundant hardwoods in the Coastal Plain, and sweetgun is a close second. ${ }^{7}$ Not all of the volume of red and white oak is good saw timber; a number of species, such as scarlet oak in the mountains, post oak in the piedmont, and water oak in the Coastal Plain, are of rather poor quality. Normally yellow poplar is in constant demand for lumber and

'There are considerable differences in the machining properties of these three species, all of which are sometimes loosely called "gum." See Davis, E. M. Machining AND RELATED CHARActeristics of SOUThers hardwoods. U. S. Dept. of Agr. Tech. Bul. 824,42 pp., illus. $19+2$. 
FICURE 26.- - The valume of saw timber in different species, North Carolina, 1938.

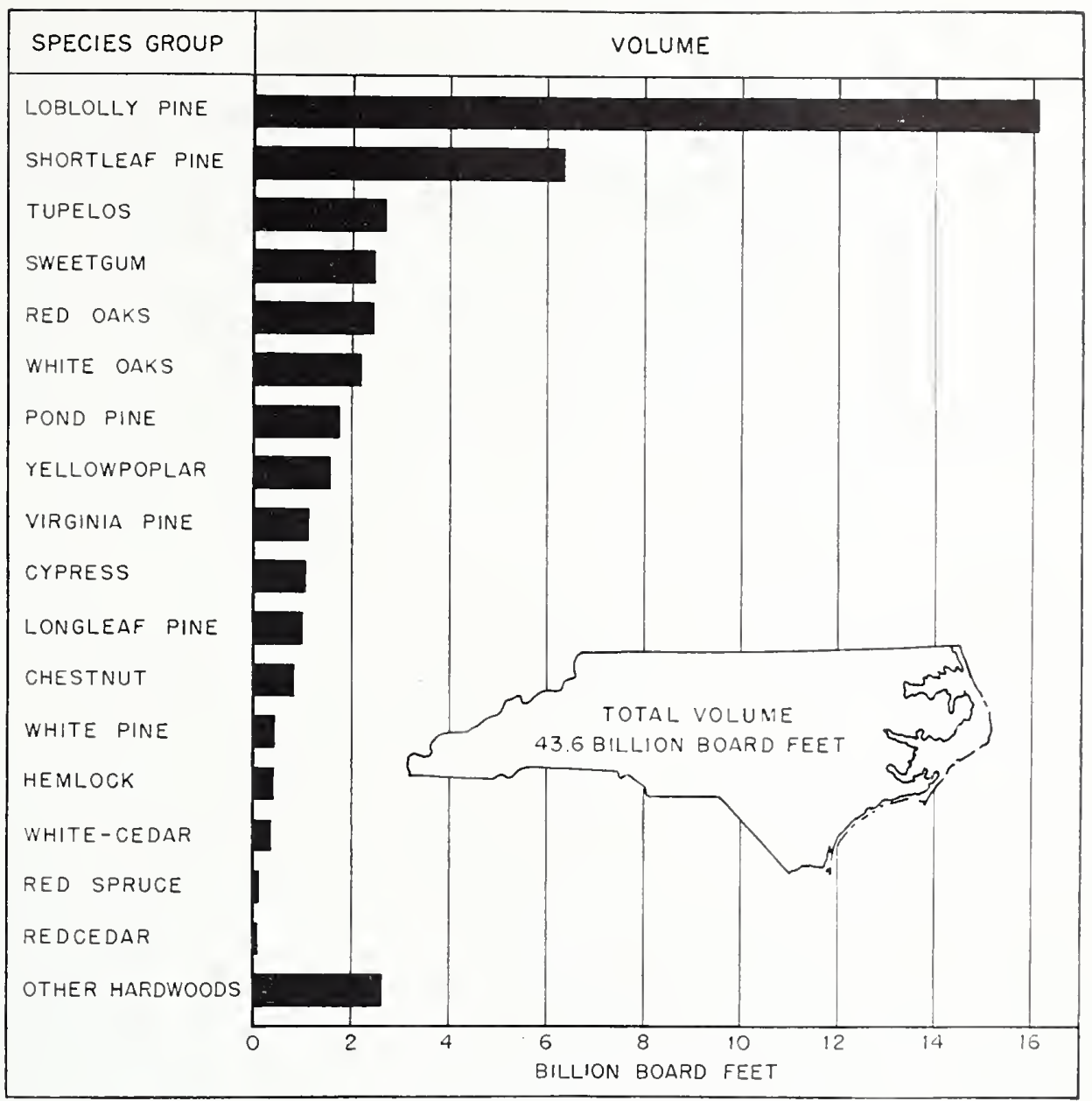

TABLE 13.- Net board-foot volume, International 1/4-inch rule, by species group and forest condition, 1938

\begin{tabular}{|c|c|c|c|c|c|c|c|c|}
\hline \multirow{4}{*}{$\begin{array}{l}\text { Softwoods: } \\
\text { Lobloily pine }\end{array}$} & \multicolumn{2}{|c|}{ Old growth } & \multicolumn{2}{|c|}{ Second growth, sawlog size } & \multirow{2}{*}{$\begin{array}{l}\text { All sawlog } \\
\text { size condi- } \\
\text { tions }\end{array}$} & \multirow{2}{*}{$\begin{array}{c}\text { Under saw- } \\
\text { log sizel }\end{array}$} & \multirow{2}{*}{\multicolumn{2}{|c|}{ All conditions }} \\
\hline & Uneut & Partly cut & Uncut & \multirow{3}{*}{$\begin{array}{c}\text { Partly cut } \\
\text { M bd.ft. } \\
\quad 4,545,300\end{array}$} & & & & \\
\hline & Mbd.ft. & $M b d . f t$ & $M b d . f t$. & & M bd.ft. & $M f b . f t$ & Mod.ft. & Percent \\
\hline & $1,495,500$ & $1,654,800$ & $7,947,000$ & & $15,642,600$ & 501,200 & $16,143,800$ & 56.1 \\
\hline Shortleaf pine... & 512,000 & 650,200 & $3,505,700$ & $1.382,500$ & $6,050,100$ & 322,300 & $6,372,700$ & 22.2 \\
\hline Pond pine .... & 314,100 & 140,200 & 929,200 & 173,800 & $1,5.77,300$ & 200,900 & $1,758,200$ & 6. 1 \\
\hline Longleaf pine .... & 39,500 & 331,600 & 303,700 & 155,600 & $830, \frac{1400}{2}$ & 160,200 & 990,600 & 3.4 \\
\hline Virginia pine. .... & 14,100 & 22,200 & 775,800 & 242,700 & $1,051,800$ & 73,300 & $1,128,100$ & 3.9 \\
\hline White pine... & 33,100 & 38,500 & 214,500 & 110,300 & 396,400 & 22,900 & 419,300 & 1.5 \\
\hline Hemlock and spruce & 212,200 & 130.300 & 95,700 & 38,300 & 476,500 & 13,100 & 483,900 & 1. 7 \\
\hline Red cedar and white-cedar & 89,700 & 76,200 & 203,700 & 10,700 & $3 \times 0,300$ & 24,300 & 404,600 & 1. 4 \\
\hline "Cypress"-... & 369,900 & 327,300 & 251,400 & 101,400 & $1,0 . \overline{0} 0,000$ & 18,400 & $1,068,400$ & 3. 7 \\
\hline Total & $3,080,100$ & $3,371,300$ & $14,226,700$ & $6,760,600$ & $2 \pi, 438,700$ & $1,336,900$ & $28,775,600$ & 100.0 \\
\hline \multicolumn{9}{|l|}{ Hardwoods: } \\
\hline Sweetgum & 543,300 & 685,800 & 659,300 & 524,700 & $2, ₫ 13,100$ & 61,300 & $2,4 i t, 400$ & 16.7 \\
\hline Black and water tupelos & $1,015,900$ & $1,011,500$ & 406,000 & 213,300 & $2, f 116,700$ & 42,200 & $2,6 \times 5,900$ & 18.1 \\
\hline Yellow poplar & 222,200 & 253,900 & 727,000 & 290,300 & $1,493,400$ & 64,300 & $1,55 \%, 700$ & 10.5 \\
\hline Red oaks ..... & 388,500 & 636,400 & 816,400 & 461,000 & $2,302,300$ & 170,400 & 2.472 .706 & 16.7 \\
\hline White oaks... & 397,200 & 757,600 & 550,400 & 334,400 & $2,034,600$ & 144,000 & $2,183,700$ & 14.7 \\
\hline Chestnut.... & 151,200 & 129,300 & 170,300 & 72.600 & 523,400 & 292,700 & 816,100 & 5.5 \\
\hline Other hardwoods & $505, \frac{100}{4}$ & 796,500 & $\pi 28,400$ & 415,300 & $2, \pm 45,600$ & 191,900 & $2,637,500$ & 17.8 \\
\hline Total... & $3,223,700$ & 4. $2 \pi 1,000$ & $4,057.800$ & $2,311,600$ & $13,864,100$ & 966,900 & 14. $\$ 31,000$ & 100.0 \\
\hline \multirow[b]{2}{*}{ All species } & $6,303,800$ & $7,6+2,300$ & $18,284,500$ & $9,072,200$ & $41,302,800$ & $2,303,800$ & $43,606,600$ & -- \\
\hline & $\begin{array}{r}\text { Percent } \\
14.5\end{array}$ & $\begin{array}{r}\text { Percent } \\
17.5\end{array}$ & $\begin{array}{l}\text { Percent } \\
\quad 11.9\end{array}$ & $\begin{array}{r}\text { Percent } \\
20.8\end{array}$ & $\begin{array}{r}\text { Percent } \\
94.7\end{array}$ & $\begin{array}{r}\text { Percent } \\
5.3 \\
\end{array}$ & $\begin{array}{l}\text { Percent } \\
100.0\end{array}$ & Percent \\
\hline
\end{tabular}

Includes second-growth, reproduction, and elear-cut conditions. 
veneer throughout the State, and with special war requirements, in addition, the 1.5 billion board feet of this species may not represent enough growing stock to assure a sustained supply. Blight has made chestnut a disappearing species. Within 10 years most of the 816 million board feet of dead chestnut saw timber will be either utilized or lost through decay.

Nearly three-fourths of the saw-timber volume is in second-growth sawlog-size stands which, in the pine types, occupy about 5.5 million acres. More than 14 billion board feet of second-growth timber is located in stands in which little, if any, cutting has taken place and nearly 7 billion feet is in partly cut stands. Only 5 percent of the softwood volume is in scattered trees in under-sawlog-size stands.

Almost one-fourth of the softwood volume is in oldgrowth stands, with approximately equal amounts on uncut and partially cut areas. One-half of the total old-growth volume is loblolly pine and nearly one-fifth is shortleaf pine. About one-third of the total board-foot volume of longleat pine and two-thirds of the total volume of hemlock, spruce, and cypress is in these old-growth stands.

More than half of the hardwood saw timber is in oldgrowth stands. This includes three-fourths of the volume of black and water tupelos as its principal component. When the cypress-tupelo swamps along the coast were first logged only the cypress was readily merchantable and large areas of black and water tupelo were left standing. In recent years improved methods of drying and machining these species have aided in demonstrating their suitability for various products. A considerable quantity of black and water tupelo is now used for veneer and furniture stock, but there is still enough tupelo to justify increased consumption for pulp and other products.

Sawlog-size second-growth stands contain 43 percent of the hardwood saw timber. Yellow poplar is rather

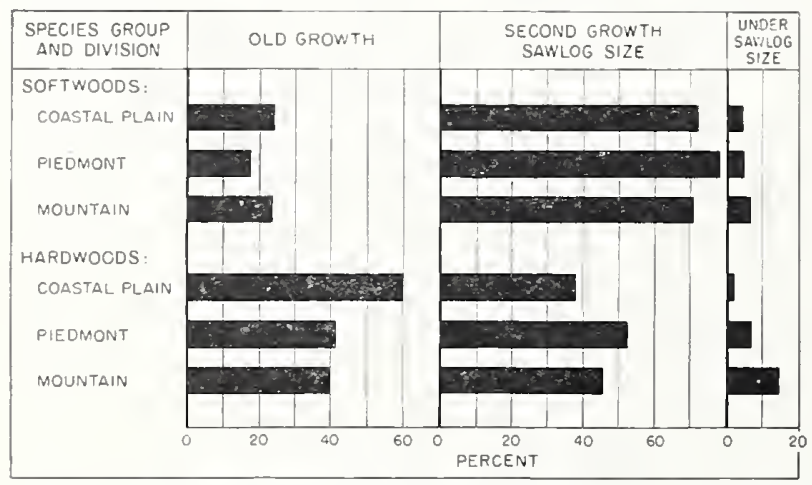

FIGURE 27.-Distribution of board-foot volume by forest condition and physiographic division, 1938. common in uncut stands, but the fact that it is generally in demand and is utilized more closely than the other hardwood species has resulted in its heavy reduction. It makes up 18 percent of the uncut-stand volume and only 13 percent of the partly cut stand. Contrawise, cutting has increased the proportion of sweetgum, because much of it being low in quality is not worth removing for saw timber.

About 7 percent of the hardwood saw timber is in stands classified as under sawlog size. This volume is in scattered trees that were considered too poor to cut when the stands were originally logged and in young thrifty trees since grown into sawlog size. Since as a rule volume is not sufficiently concentrated to justify logging, utilization of most of it will be delayed until the young stands grow to sawlog size.

Distribution is not radically different in the three geographical divisions of the State (fig. 27). The high proportion of softwood volume in the second-growth sawlog-size condition is especially pronounced in the piedmont. Mature stands of cypress and white-cedar increase the percent of old-growth softwood volume in the Coastal Plain and hemlock has a similar effect in the mountain division.

In the Coastal Plain less intensive utilization accounts for the 60 percent of the hardwood volume still in old-growth stands, about two-fifths of it in black and water tupelos. The piedmont and mountain divisions contain about equal proportions of old-growth volume, but with quality differences. In the piedmont nearly three-fourths of the oldgrowth volume is in stands from which the best trees have been cut. Less severe partial cutting in the mountains has left old-growth stands more nearly like virgin timber, containing more of the better-quality hardwoods, such as yellow poplar, basswood, northern red oak, white oak, sugar maple, and ash.

\section{Volume by Diameter Class}

Efficient utilization must be based on a knowledge of volume distribution by tree-diameter classes. Small trees require more labor per thousand board feet in logging, and logging and milling equipment cannot be operated at top efficiency on small logs. The larger trees also yield a greater proportion of upper grades and wider boards. On small sawmill operations, however, the benefits to be obtained from cutting only large trees are closely restricted; the cut per acre is necessarily reduced and mill-moving costs or log-hauling costs may offset the saving. Moreover, small mills are not equipped to handle large logs efficiently.

Studies of pine roofer operations in eastern North Carolina indicate that the most profitable balance is reached 
when the minimum cutting limit is about 16 inches $\mathrm{d}$. b. h. About two-fifths of the loblolly pine and one-fourth of the shortleaf pine volume is in trees at least this size. For hardwoods the minimum limit is generally, higher but varies by species, age of timber, and kind of product. Two-fifths of the hardwood volume is in trees 19 inches d. b. h. and larger (table 14).

TABLE 14.-Distribution of the net board-foot volume (International 1/4-inch rule) by species group and tree-diameter class, 1938 1

\begin{tabular}{|c|c|c|c|c|}
\hline Species group & $\begin{array}{c}10-12 \\
\text { inches }\end{array}$ & $\begin{array}{c}\text { 14-18 } \\
\text { inches }\end{array}$ & $\begin{array}{c}20-24 \\
\text { inches }\end{array}$ & $\begin{array}{c}26+ \\
\text { inches }\end{array}$ \\
\hline Softwoods: & Percent & Percent & Percent & Percent \\
\hline Loblolly pine & 38.6 & 44. 5 & 13.5 & 3.4 \\
\hline Shortleaf pine & 58.8 & 34.4 & 6.1 & 7 \\
\hline Pond pine & 51.4 & 43.5 & 4. 2 & .9 \\
\hline Longleaf pine - - & 40.9 & 44.8 & 12. 9 & 1.4 \\
\hline Virginia pine $\ldots . . . .$. & 69.6 & 29.5 & .9 & (2) \\
\hline White pine & 28.3 & 37.3 & 21.6 & 12.8 \\
\hline Hemlock & 7.4 & 21.2 & 21.3 & 50.1 \\
\hline Red spruce & 34.8 & 51.3 & 13.9 & $(2)$ \\
\hline Red cedar & 61.5 & 28.9 & 9.6 & (2) \\
\hline White-cedar & 49.8 & 42.9 & 4.7 & 2. 6 \\
\hline Cypress $\ldots . . . . . . . .$. & 25.4 & 36.8 & 22.6 & 15. 2 \\
\hline All softwoods. & 44.3 & 40.9 & 11.2 & 3.6 \\
\hline \multicolumn{5}{|l|}{ Hardwoods. } \\
\hline Sueetgum & & 62.7 & 24.9 & 12.4 \\
\hline Black and water tupelo. & & 59.0 & 29.9 & 11. 1 \\
\hline Yellow poplar & & 62.5 & 25.7 & 11.8 \\
\hline Red oaks . . . . . . & & 54.0 & 30.2 & 15. 8 \\
\hline White oaks & & 52.1 & 27.4 & 20.5 \\
\hline Chestnut . . . . . & 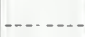 & 29.7 & 34.0 & 36.3 \\
\hline Other hardwoods ... & & 66.8 & 22.6 & 10.6 \\
\hline All hardwoods. & & 57.9 & 27.2 & 14. 9 \\
\hline All species & $\left({ }^{3}\right)$ & 65.9 & 23.5 & 10. 6 \\
\hline
\end{tabular}

${ }^{1}$ For similar distribution by physiographic divisions, see table 39 . appendix. 2 Negligible.

3 The volume of softwoods in the 10-12-inch class is not included in the rolume from which all-species percents are derived.

The distribution of the softwood volume by tree-diameter class is more favorable for profitable sawmilling in the Coastal Plain than in the piedmont (fig. 28), as shown by the 40 percent of the volume in 10 -12-inch diameter class in contrast with nearly 60 percent in the piedmont. In the mountain region the larger percentage of softwood volume in trees 25 inches d. b. h. and over is mostly hemlock, generally considered a poor species.

In the mountain region an even higher proportion of hardwood volume is in the larger diameters. Again a single species has a strong influence, for over one-third of the volume in trees 26 inches $\mathrm{d}$. b. h. and larger is dead chestnut. In the piedmont a large part of the hardwood volume is in small trees because most of the largest, bestquality timber has been cut, and the second-growth oak and sweetgum is still relatively immature. Here the oaks grow slowly and many trees are 80 to 100 years old before they reach minimum saw-timber size.

It seems inconsistent to find such a large part of the hardwood volume in trees smaller than 20 inches d. b. h. in the Coastal Plain, where, according to figure 27, 60 percent of the volume is in old-growth stands. One explanation is that two-thirds of the volume in the smallest diameter group is sweetgum and black and water tupelo. These species have reproduced prolifically in the partly cut oldgrowth stands of swamp hardwoods, and small secondgrowth trees form an important part of the stand volume. Another reason is that many pure stands of old-growth black and water tupelos are densely stocked with tall trees of medium diameter.

\section{Lolumes Per Acre}

Volume per acre is the primary standard for judging a logging chance. Size, age, quality, and location of the timber are taken into consideration, but there must be enough saw timber per acre to support the operation. The minimum varies with the type of operation, the terrain, and the kind of timber. Stationary mills supplied by logging railroads must operate in heavy stands of extensive acreage in order to repay the large investment in railroad and logging equipment. As a rule the second-growth stands of North Carolina are too light and too scattered for railroad logging. The development of portable sawmills, efficient motortrucks, and a network of improved highways has altered former concepts of an operable timber stand. For truck logging to a stationary mill, a stand of 2,000 board feet per acre is considered a fair logging chance. Operators of portable sawmills, however, will set up for as little as 300 feet per acre if the timber is within a quarter of a mile of the mill.

Judging by these standards, most of the board-foot volume in the sawlog-size conditions can be profitably cut. More than two-thirds of the land is stocked 2,000

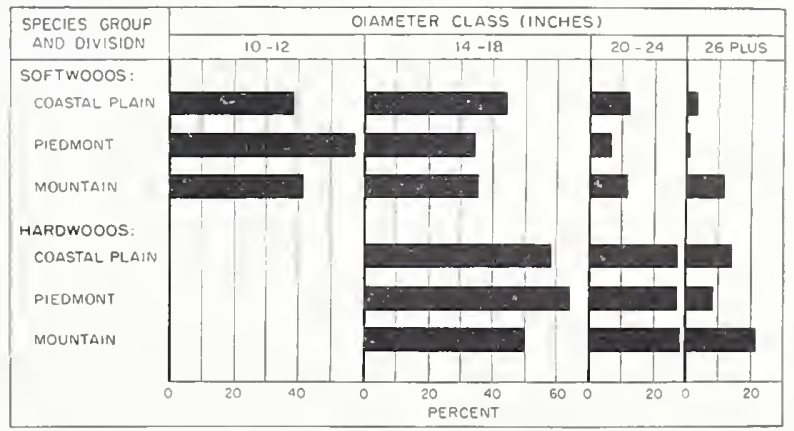

FIGURE 28.-Distribution of board-foot volume by diameter class, 1938 


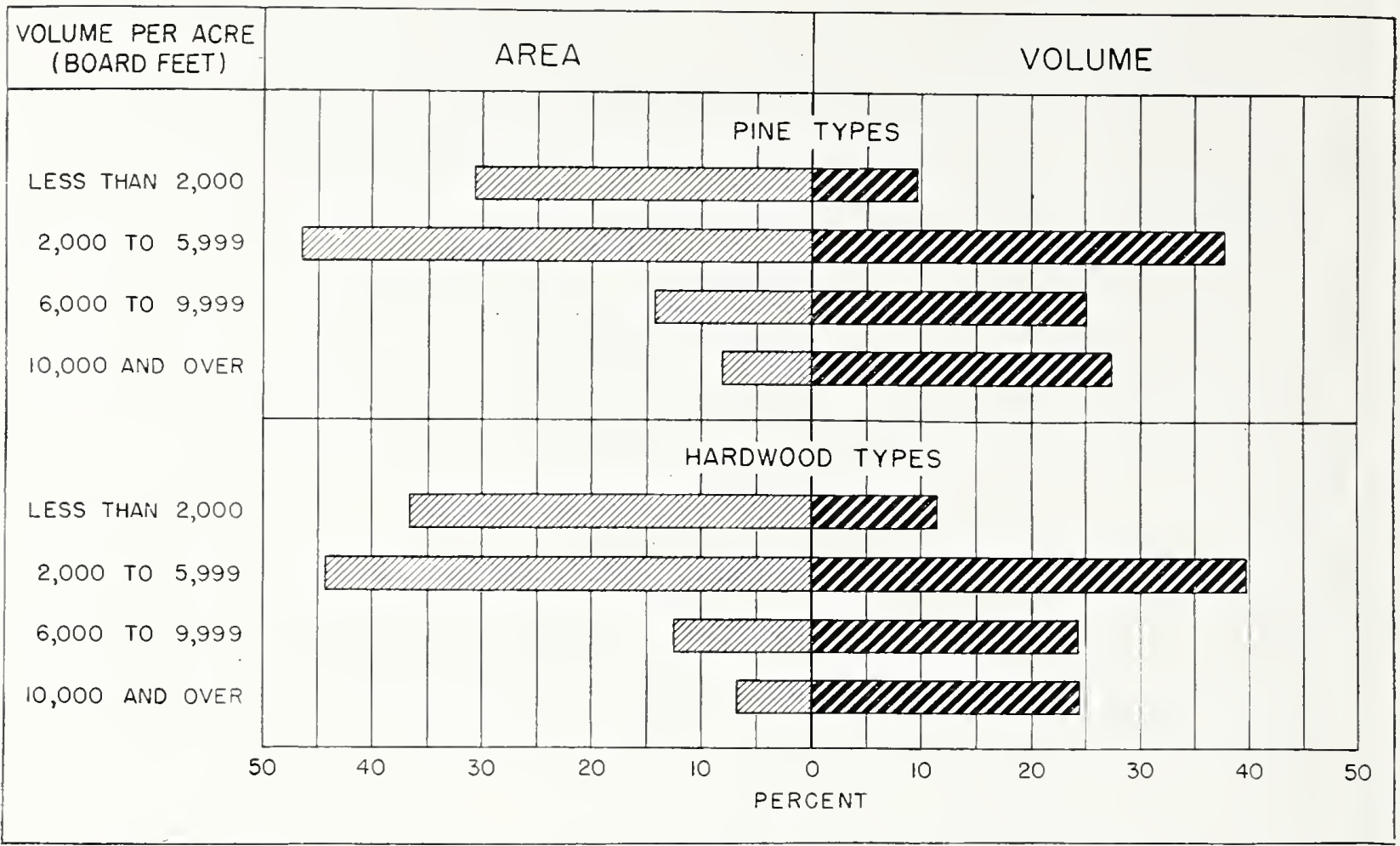

FIGURE 29.-Distribution of area and board-foot volume in the sawlog-size conditions according to the volume of saw timber per acre, 1938.

board feet per acre or better and these stands contain about nine-tenths of the volume in each type group (fig. 29). About one-fifth of the total saw-timber area, 2 million acres, bears more than 6,000 feet per acre and embraces one-half of the board-foot volume in the sawlogsize conditions. Stands stocked with less than 2,000 feet per acre occupy about one-third of the sawlog-size area in both the pine and hardwcod types, but they contain only one-tenth of the saw timber.
Average volumes per acre are usually largest in the loblolly pine type (table 15). The 15,390 board feet per acre of old-growth uncut stands occurs on less than 100,000 acres. More important from the commercial point of view is the 5,670 board feet per acre in secondgrowth uncut stands of loblolly that represents 1.5 million acres. All together the sawlog-size loblolly pine stands, totaling 3.2 million acres, average 5,130 feet per acre and contain 40 percent of the total saw-timber volume.

TABIE 15.- ferage bnard-foot volume ${ }^{1}$ per acre, total area, and total colume of the sawlog-size conditions by forest type, 1938

\begin{tabular}{|c|c|c|c|c|c|c|c|}
\hline \multirow{2}{*}{ Forest type } & \multicolumn{2}{|c|}{ old growth } & \multicolumn{2}{|c|}{ Second growth } & \multirow{2}{*}{$\begin{array}{l}\text { All sawlog } \\
\text { conditions }\end{array}$} & \multirow{2}{*}{ Total area } & \multirow{2}{*}{ Total rolume } \\
\hline & Uneut & Partly cut & Uneut & Partly cut & & & \\
\hline & Board feet & Board feet & Board feet & Board feet & Board feet & Acres & M board yed \\
\hline Loblolly pine & 15,390 & 7,830 & 5,670 & 3,510 & 5,130 & $3,214,400$ & $16,475.600$ \\
\hline Shortleaf pine ........... & 11,510 & 5,550 & 4,320 & 2,690 & 4,060 & $1,718,400$ & $6,971,700$ \\
\hline Pond pine & 3,150 & 2,790 & 2,400 & 1,940 & 2,480 & 650,700 & $1,615.800$ \\
\hline Longleaf pine. ....... & 4. 780 & 3,510 & 2,290 & 2,070 & 2,700 & 212,400 & 572,900 \\
\hline Virginia pine..... & 8,840 & 4,560 & 3,570 & 2,760 & 3,410 & 326,900 & $1,113,600$ \\
\hline White pine ${ }^{2} \ldots \ldots$ & 9,100 & $8,0 \leq 0$ & 3,890 & 2,910 & 4,820 & 199. 700 & 962,500 \\
\hline Cove hardwoods . & 11,000 & 5,020 & 3,930 & 2,440 & 4,360 & 182,300 & 795,700 \\
\hline Bottom-land hardwoods & 9,740 & 6,380 & 3,950 & 2,940 & 5,620 & $1,466,100$ & $8,234,200$ \\
\hline 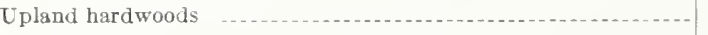 & 5,700 & 3,810 & 2,110 & 1,750 & 2,730 & $1,672,600$ & $4,560.500$ \\
\hline All types.. & 8,820 & 5.470 & 4,140 & 2,910 & 4,280 & $9,643,500$ & $41,302,8(0)$ \\
\hline
\end{tabular}

1 Net volumes by the International 1 -inch log rule.

Includes spruce-fir and hemlock types. 
TABLE 16.- Net corduood volume of all sound material by species group and quality class, 1938

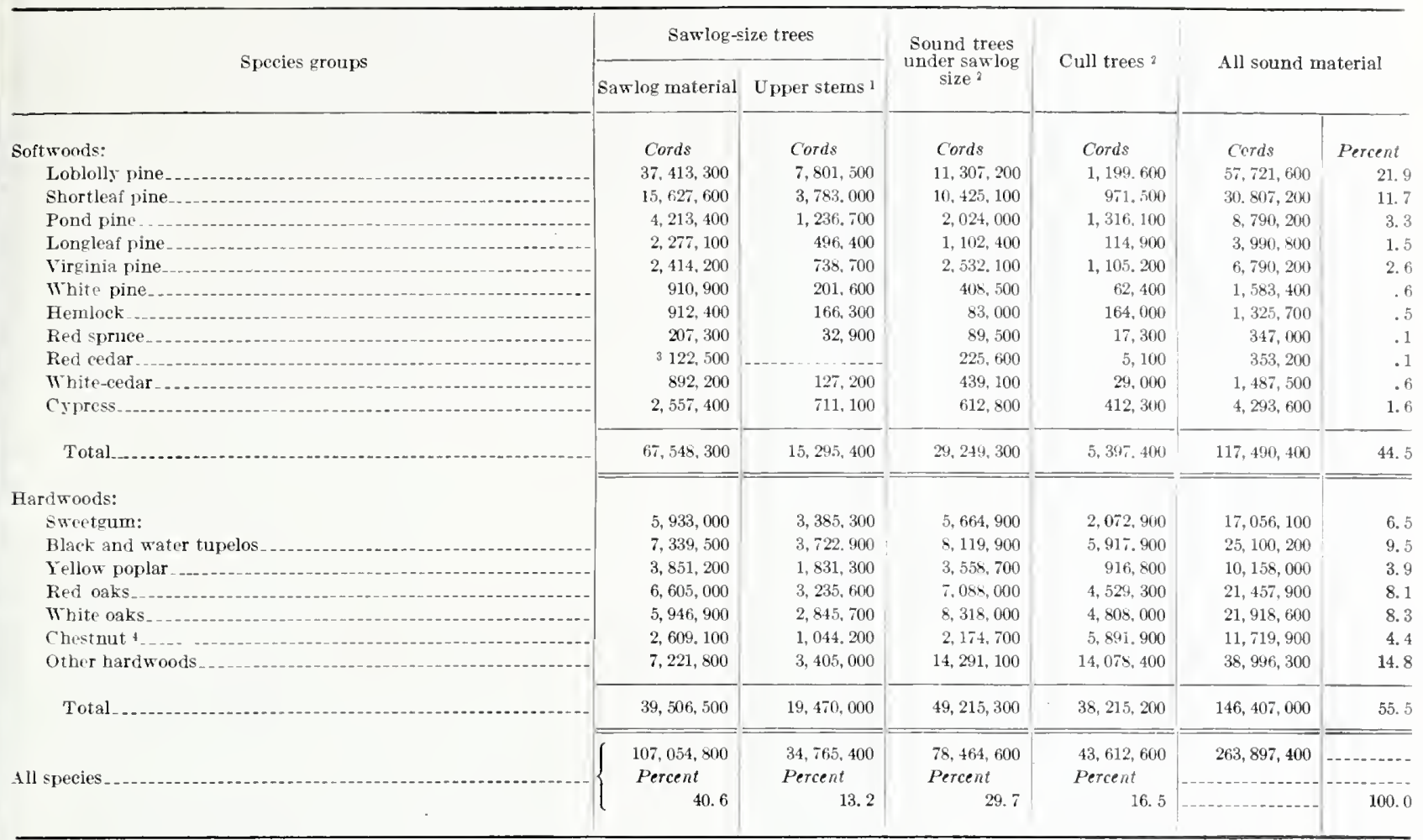

1 To a minimum diameter of 4 inches outside bark. Includes large limbs in hardwoods

${ }^{2}$ At least 5 inches d. b. h.

${ }^{3}$ Entire stcm to a minimum 4-inch top considered sawlog material; hence, there is no additional volume in upper stems.

1 Sound dead chestnut usable for saw timber and extract wood.

These average volumes per acre by forest type also provide a measure of timber conditions in the different parts of the State. The loblolly pine and bottom-land hardwoods types, which have the heaviest average volumes per acre, occupy more than three-fifths of the forest land in the Coastal Plain. In the piedmont the average volume of 4,430 board feet per acre in the sawlog-size shortleaf pine stands affords fair opportunities for utilization without destroying the growing stock. Three-fifths of the mountain forests are upland hardwoods with an average volume of less than 2,600 feet in the saw-timber stands, indicating that they are badly understocked and low in productivity.

\section{Cordwood Volume}

The total volume of sound wood measured in cords is remarkably high-2.5 times the volume of all sawlogs (table 16). The 107 million cords of sawlog material is identical with the wood reckoned above in board feet. The 35 million cords in upper stems of sawlog-size trees includes in hardwoods large limbs. The 43.6 million cords in cull trees comprises sound material in the stems of cull softwoods and the stems and limbs of cull hardwoods.

\section{Volume by Class of Material}

About 45 percent of the cordwood volume is softwood. Sawlog-size trees with their upper stems, contain 70 percent of the volume, under-sawlog-size trees 25 percent, and cull trees only 5 percent. Two-thirds of the sawlog material and upper stems is in the Coastal Plain, where loblolly pine is a major component (appendix, table 41). Under-sawlog-size trees make up less than one-fifth of the stand in the northern Coastal Plain, but the proportion is greater in other parts of the State; in the piedmont, where much of the old-field shortleaf and Virginia pine is immature, one-third of the softwood volume is in these small trees. Cull trees are not particularly common among the softwoods; here nearly half of the cull volume is in relatively inferior pond and Virginia pines.

The quality of material making up the hardwood volume differs markedly from that of the pines. Only 27 percent is sawlog material, partly because hardwoods are considered under sawlog size until they are 13 inches d. b. h. Even when upper stems and limbs are included, sawlog-size trees account for only 40 percent of the hardwood volume, of which nearly half is in the Coastal Plain. 
TABLE 17. -Net cordwood colume in stems of sound tress by species group and tree-diameter class, 19381

\begin{tabular}{|c|c|c|c|c|c|c|}
\hline Species oroup & $\begin{array}{c}6-8 \\
\text { inches }\end{array}$ & $\begin{array}{l}10-12 \\
\text { inches }\end{array}$ & $\begin{array}{c}14-18 \\
\text { inehes }\end{array}$ & $\begin{array}{c}20+ \\
\text { inches }\end{array}$ & \multicolumn{2}{|c|}{5 inches and larger } \\
\hline \multicolumn{7}{|l|}{ Softwoods: } \\
\hline Loblolly pine & 11,307 & 20,409 & 18,840 & 5,966 & 56,522 & 23.3 \\
\hline Shortleaf pine ... & $10,+25$ & 12,491 & 5,947 & $9 \pi 1$ & 29,834 & 14.9 \\
\hline Pond pine & 2,024 & 3,064 & 2,175 & 211 & 7,474 & 3.7 \\
\hline Longleaf pine.. & 1,103 & 1,288 & 1,157 & 330 & $3,5,8$ & 1.9 \\
\hline Virginia pine & 2,532 & 2,255 & 876 & 22 & 5,685 & 2.8 \\
\hline White pine ... & 408 & 377 & 415 & 321 & 1, 521 & .8 \\
\hline Hemlock & 83 & 125 & 263 & 691 & 1,162 & .6 \\
\hline Red spruce... & 90 & 95 & $11 i$ & 28 & 330 & .2 \\
\hline Red cedar & 225 & 77 & 35 & 11 & 348 & 2 \\
\hline White-cedar... & 439 & 553 & $40 \pi$ & 59 & 1,458 & .7 \\
\hline Cypress & 613 & 693 & $1.03-$ & 827 & 3. 170 & 1.6 \\
\hline Total & 29,249 & 41,427 & 31,269 & 9,437 & $111,3 * ?$ & 55. 7 \\
\hline \multicolumn{7}{|l|}{ Hard woods: } \\
\hline Black and water tupelos & 3,118 & 4,972 & $\begin{array}{l}3,913 \\
4,593\end{array}$ & 2,746 & $\begin{array}{l}11,59 \\
15,459\end{array}$ & 7.8 \\
\hline Yellow poplar & 1,688 & 2,185 & 2. 303 & 1,234 & $7 .+10$ & 3. 7 \\
\hline Red oaks... & 3,152 & 3.936 & 3. $\$ 53$ & 2. 752 & 13,693 & 6.9 \\
\hline White oaks. - & 3,719 & 4,598 & 3. 383 & 2. 565 & 14,265 & 7. 1 \\
\hline Chestnut_... & $\pi 2$ & 1,403 & $\$ 58$ & 1,751 & 4,784 & 2.4 \\
\hline Hickory .. .... & 1,230 & 1,644 & $1.16 \pi$ & 421 & 4,462 & 2.2 \\
\hline other hardwoods..... & 5. 754 & 5,371 & 4,133 & 1. 793 & 17,051 & 8. 5 \\
\hline \multirow[t]{2}{*}{ Total } & 22,030 & $2 \bar{\tau}, 206$ & 24,203 & 15,283 & 88,722 & 41.3 \\
\hline & 51,279 & 68,633 & 55,472 & 24.720 & 200,104 & 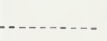 \\
\hline All species.. & $\begin{array}{l}\text { Percent } \\
25.6\end{array}$ & $\begin{array}{r}\text { Percent } \\
34.3\end{array}$ & $\begin{array}{r}\text { Percent } \\
27.7\end{array}$ & $\begin{array}{c}\text { Percent } \\
12.4\end{array}$ & & 100.0 \\
\hline
\end{tabular}

1 For detailed data by phssiographic regions, see table 40, appendix, p. 74.

The volume of sound under-sawlog-size trees amounts to one-third of the total hardwood stand. In the mountains particularly, most of these young hardwoods, as the future source of saw timber, should be retained in the growing stock and managed for that use. On the pine lands they are often less desirable because they tend to replace the faster growing and more easily marketed pine. The coastal swamps contain a great quantity of immature black and water tupelos which will become valuable for pulp, lumber, and veneer (fig. 30). Cull hardwoods, aggregating a large volume, are present on nearly all the forest land. To devise methods of removing these hard-to-use trees at a profit is a major problem of forest management and economics. The mountain forests will never produce satisfactory yields of timber as long as one-third of the hardwood volume is in cull trees.

\section{Volume by Diameter Class}

Of the total volume in stems of sound trees 5 inches $\mathrm{d}$. b. h. and larger, the high proportion contained in small trees (table 17) indicates the young, immature character of the forest. Almost two-thirds of the softwood volume and well over one-half of the hardwood is in trees less than 13 inches d. b. h. Among the common softwoods shortleaf pine (77 percent) and Virginia pine $(84$ percent) have an outstanding part of their volume in small trees. These species are most prevalent in the piedmont, where more than 1,500 sawmills compete for the larger saw timber. The proportion of hardwood volume in small trees-especially of sweetgum, white oak, and hickory-is also greatest in the piedmont.

\section{Volume per Acre}

The average of 11.4 cords per acre for all forest land (table 18) includes all sound trees 5 inches d. b. h. and larger, but not the sound material in cull trees or upper stems and limbs of hardwoods. Saw-timber stands average 18 cords per acre, varying from 9.7 cords in the pond pine type to 22.9 cords in the bottom-land hardwoods type. Sawlog-size loblolly pine, occupying over 3 million acres, averages 19.3 cords per acre. The 1.7 million acres of sawlog-size upland hardwoods, by contrast, average only 14.5 cords. Under-sawlog-size stands of all types, which occupy 47 percent of the forest land, have an average volume of only 4 cords per acre. It is evident that action is needed to increase the volume of growing stock in many of these younger stands, so that in time they may approach the yield of old-growth uncut stands, averaging over 28 cords per acre. 
TABLE 18.-Average cordwood volume per acre of sound trees ${ }^{1}$ by forest type and forest condition, 1938

\begin{tabular}{|c|c|c|c|c|c|c|}
\hline \multirow{2}{*}{ Forest type } & \multicolumn{2}{|c|}{$\begin{array}{l}\text { Old growth, } \\
\text { sawlog size }\end{array}$} & \multicolumn{2}{|c|}{$\begin{array}{l}\text { Second growth, } \\
\text { sawlog size }\end{array}$} & \multirow{2}{*}{$\begin{array}{l}\text { Under } \\
\text { sawlog } \\
\text { size? }\end{array}$} & \multirow{2}{*}{$\begin{array}{l}\text { A ver- } \\
\text { age all } \\
\text { eondi- } \\
\text { tions }\end{array}$} \\
\hline & Uncut & $\begin{array}{c}\text { Partly } \\
\text { cut }\end{array}$ & Uncut & $\begin{array}{l}\text { Partly } \\
\text { cut }\end{array}$ & & \\
\hline & Cords & Cords & Cords & Cords & Cords & Cords \\
\hline Loblolly pine & 41. 5 & 23. 2 & 22.0 & 14.6 & 3.4 & 14.4 \\
\hline Shortleaf pine & 32.5 & 19. 2 & 20,4 & 14.5 & 4. 6 & 12.4 \\
\hline Pond pine -- & 10. 5 & 10.1 & 9.8 & 7.7 & 1.2 & 4. 0 \\
\hline Longleaf pine - & 14,4 & 10.1 & 10.5 & 8.3 & 1.8 & 3.8 \\
\hline Virginia pine -_ & 28.0 & 15.7 & 17.2 & 12.7 & 3.6 & 8. 7 \\
\hline White pine... & 28.5 & 24.2 & 17,9 & 14.7 & 5.3 & 15.4 \\
\hline Cove hardwoods & 37.5 & 20.2 & 19.9 & 14.9 & 6.9 & 13.8 \\
\hline Bottom-land hardwoods & 32.6 & 23,4 & 20.9 & 15.5 & 4. 2 & 16.6 \\
\hline Upland hardwoods. . . & 23.9 & 16. 6 & 13. 3 & 11.5 & 5.9 & 9.6 \\
\hline All types. & 28.7 & 19. 7 & 18.6 & 13.8 & 40 & 11.4 \\
\hline
\end{tabular}

1 Includes material in stems of all sound trees 5 inches d. b. h. and larger. ${ }^{2}$ A verage of second-grow th, reproduction. and clear-cut conditions.

\section{Cubic-foot Volume}

The net cubic-foot volume of sound wood in trees 5 inches d. b. h. and larger, exclusive of chestnut, is summarized in table 19. Bark is not included; otherwise the material is the same as that expressed in cords in table 16 . The 13.4 billion feet of growing stock is the forest capital. If this principal is to be kept reasonably intact while industries are supported by the interest it earns, the average annual cut should not exceed the annual growth of such potential saw timber. The drain upon the growing stock can be reduced if greater use is made of the 3.5 billion cubic feet of other sound wood in cull trees and upper stems and limbs of sawlog-size hardwoods. At present most of the small-dimension and part-cull wood is taken only for fuel and there is a pressing need for forest products research to develop new and better markets for this kind of material.

TABLE 19.-Net cubic-foot volume of all sound wood, by class of material and species group, 1938

\begin{tabular}{|c|c|c|c|}
\hline Class of material & Softwoods & $\begin{array}{c}\text { Hard- } \\
\text { woods : }\end{array}$ & Total \\
\hline Growing stock: & & & $M c u \cdot \gamma_{i}$ \\
\hline Sawlogs & $4,896,600$ & $2,470,740$ & $\bar{i}, 367,340$ \\
\hline $\begin{array}{l}\text { Upper stems of softwood saw } \\
\text { timber. }\end{array}$ & 1. 085,480 & & $1,085,450$ \\
\hline Sound trees of under-sawlog size & $1,965,120$ & $2,957.390$ & $4,922,510$ \\
\hline Total ... & $\pi, 947,200$ & $5,428,130$ & $13,375,330$ \\
\hline $\begin{array}{l}\text { Other sound wood: } \\
\text { Upper stems of hardwood saw } \\
\text { timber. }\end{array}$ & & $1,0 \$ 3,020$ & $1,0 \$ 3,020$ \\
\hline Cull trees & 383,310 & $2,069,650$ & $2,452,960$ \\
\hline Total .. & 383.310 & $3,152,670$ & $3,535,950$ \\
\hline All material. & $8,330,510$ & $8,580,800$ & $16,911.310$ \\
\hline
\end{tabular}

1 Clestnut is not included.

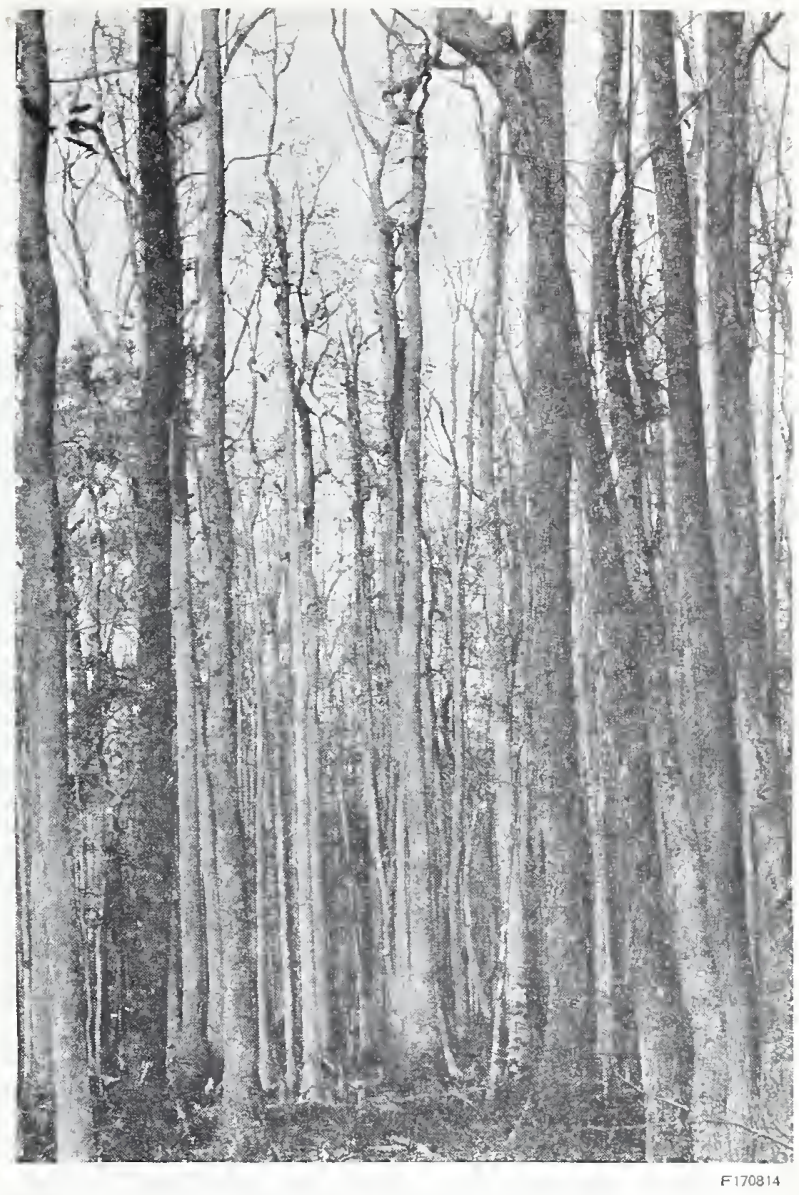

FIGURE 30:-Immature black and water tupelas in Gates County. Ther are 25 million curds of these species in the Coastal Plain.

\section{Pine Poles}

Many of the loblolly, shortleaf, and longleaf pine trees included in previous tabulations of volume are suitable for use as poles. Estimates based on classification of individual trees in the woods indicate that there are about 47 million poles in the pine forests of the piedmont and Coastal Plain (table 20). On the average, about every seventh pine tree between 7 and 18.9 inches in diameter is sufficiently straight, clear, and uniformly tapered to qualify as pole material (fig. 31), and only 1 out of 10 of these poles will be longer than 30 feet. More than half of the potential poles are only 20 feet long and almost threefourths of them represent trees less than 11 inches $d . b$. h. The best source of long poles is the northern part of the Coastal Plain, particularly in the loblolly pine stands between the Roanoke and Chowan Rivers. Although there are a great number of poles scattered throughout the eastern and central parts of the State most of them will be cut for sawlogs, pulpwood, or other products. To meet this competition, wood-treating plants and other consumers usually have to pay a premium for pole timber. 


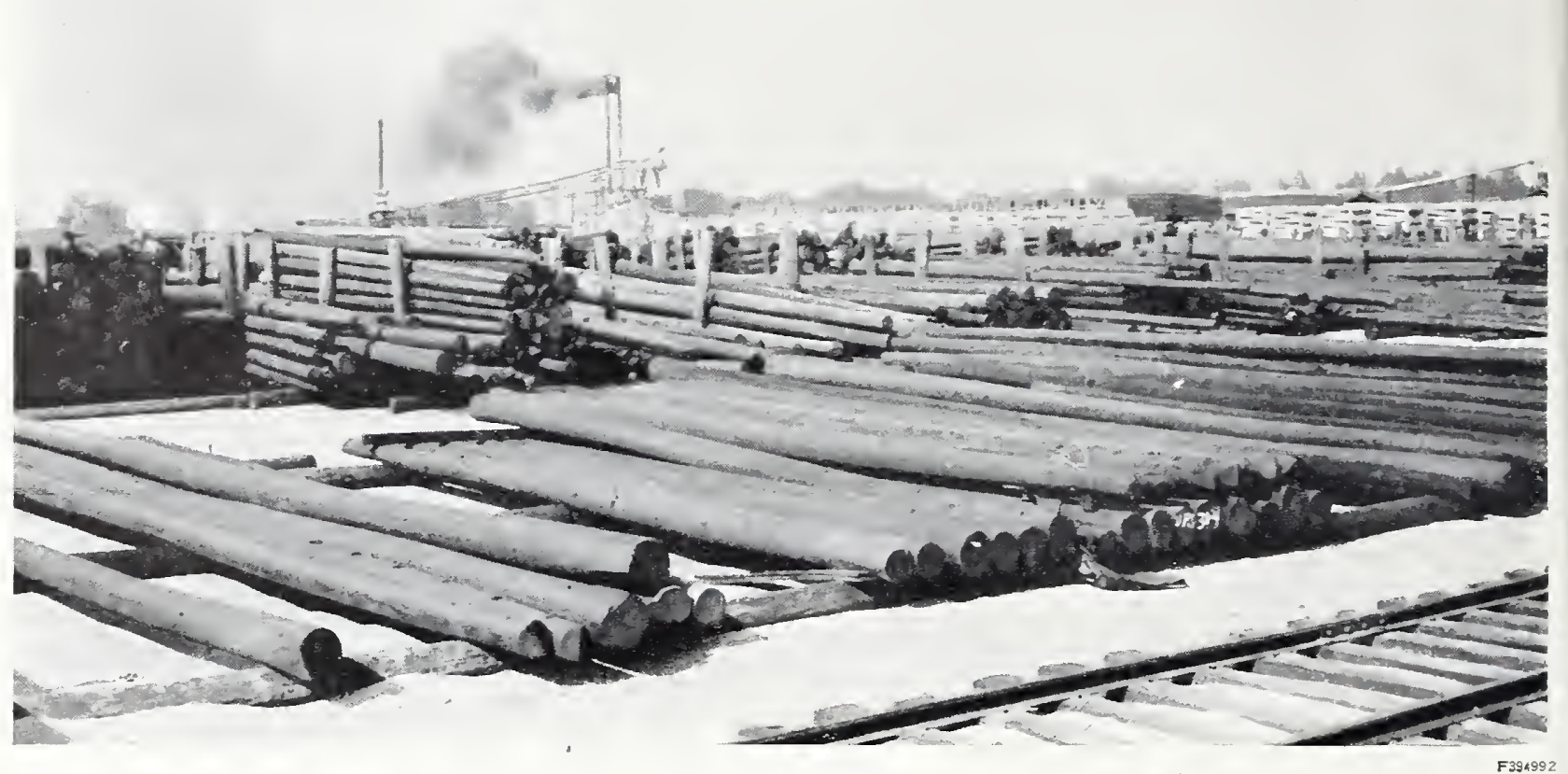

Figure 31.- In 1938 about 15!,000 pine poles were delivered to Portsmouth and Norfnlk, I'a., and Wilmington, N. C.

\section{Tanning Material}

Chestnut wood, chestnut oak bark, and hemlock bark used in the manufacture of tanning extract are cut only in the forests of the mountain region. Practically all of the chestnut trees are dead, but still usable for extract. The total amount of sound chestnut wood is about 11.7 million cords (table 21), but not all of it will be available to extract plants. Stumpage prices are higher for chestnut saw timber than for extract wood; timber owners will endeavor to sell most of the 2.6 million cords of chestnut sawlogs to sawmill operators. Furthermore, about
625,000 cords of the nonsawlog material is in scattered trees in the pine stands and is probably economically unavailable. Experts familiar with the region estimate that about 60 percent of the remaining 8.5 million cords can be utilized. Extract plants have, therefore, a reserve supply of about 5 million cords, which will either be consumed within the next 10 to 15 years or largely lost through decay. 8 The distribution of the chestnut timber is indicated in figure 32 .

8 In this connection it may be of interest to refer to Forest Prod. Lab. Tech. Note 224, a utilization guide for Blight-killed chestsut. ${ }^{4}$ pp. [Processed.]

TABLE 20.-Total number of pine poles ${ }^{1}$ by length and tree-diameter class, 1938

\begin{tabular}{|c|c|c|c|c|c|c|c|c|}
\hline Tree-diameter class (inches) & 20 leet & 25 feet & 30 feet & 35 feet & 40 feet & 45 feet or & \multicolumn{2}{|c|}{ Ail lengths } \\
\hline it to 8.9 & $\begin{array}{r}1,000 \text { poles } \\
13,140\end{array}$ & $\begin{array}{r}1,000 \text { poles } \\
3,228\end{array}$ & $\begin{array}{r}1,000 \text { poles } \\
1,173\end{array}$ & 1,000 poles & 1,000 poles & 1,000 poles & $\begin{array}{r}1,000 \text { poles } \\
17,5+1\end{array}$ & $\begin{array}{c}\text { Percent } \\
37.1\end{array}$ \\
\hline 9 to 10.9 & $9,0 \pi 4$ & 4,184 & 2,650 & 843 & 192 & 30 & 16,973 & 35.9 \\
\hline 11 to 12.9 & 2,625 & 2,608 & 2,021 & 998 & 378 & 230 & 8.860 & 15. 7 \\
\hline 13 to $14.9 \ldots$ & 165 & 673 & 986 & 846 & 302 & 192 & 3,164 & 6.7 \\
\hline 15 to 16.9 & & 43 & 154 & 192 & 163 & 168 & 720 & 1.5 \\
\hline \multirow[t]{3}{*}{17 to $18.9_{\ldots}$} & & & & 3 & 12 & 28 & 43 & .1 \\
\hline & 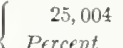 & 10, 736 & $\begin{array}{r}\text { 6,984 } \\
\text { Percent }\end{array}$ & $\begin{array}{r}2, \times 2 \\
\text { Pescont }\end{array}$ & 1,047 & 648 & $4 \pi, 301$ & .... \\
\hline & 52.9 & 227 & 147 & 6.1 & 2,2 & 1.4 & & 100.0 \\
\hline
\end{tabular}

1 To estimate of pole material was made in the mountain region. Includes loblolly, shortleaf, and longleaf pine. 


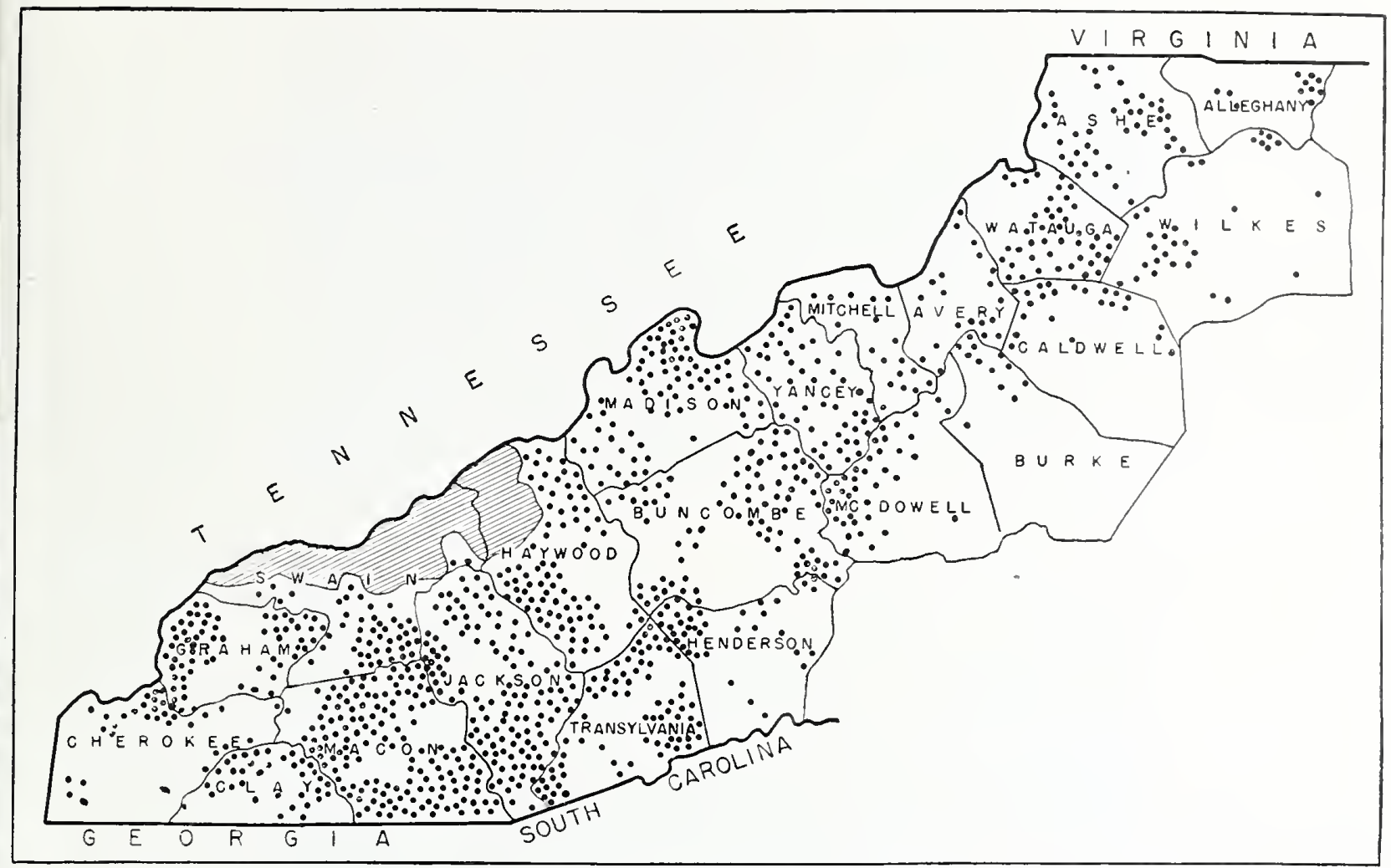

FIGURE 32.-Chestnut is most abundant in the southwestern half of the nountain region, as illustrated in this geographical distribution of chestnut timber. Each dot represents a quarter-acre plot containing at least three sound trees 10 inches $d . b$. h. or larger.

From the board-foot volume of standing timber it is estimated that approximately 440,000 tons of chestnut oak bark and 320,000 tons of hemlock bark are on sound growing trees and an additional 400,000 tons of chestnut oak bark are on cull trees. Some of the bark on sound trees will be wasted when unpeeled logs are sawed for lumber while that on culls is expensive to obtain because the trees are located on the higher, less acessible ridges where they would have to be cut for the bark alone.
TABLE 21. - Net corlwood volume of chestnut by class of material, 1935

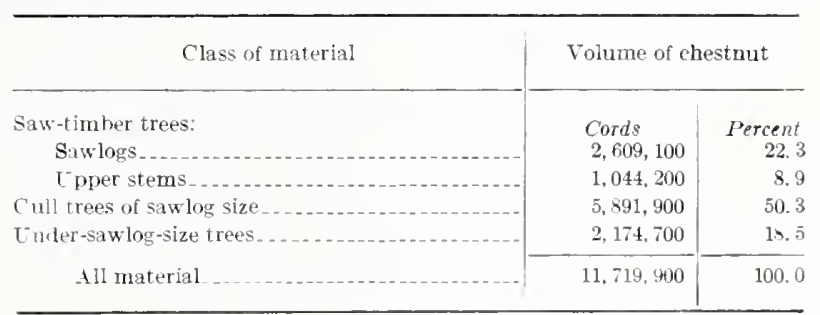




\section{The Forest-Products Industries}

$\mathrm{T}$ HE timber resources already described provide raw material for several active forests-products industries. Lumber accounts for nearly half of the value of output, but other wood products are increasingly important. Many different tree species and local markets for a diversity of items make possible a wider range of forest industrial activity than is found in most forest areas of equal size.

The growth of the furniture industry in North Carolina has stimulated the manufacture of furniture veneers and plywood, dimension stock, and excelsior. Likewise the production of fruit, potatoes, and other vegetables for market has created a demand for baskets, hampers, barrels, crątes, and other containers supplied by local package veneer and cooperage plants. The expanding pulp and paper industry finds an ample supply of pulping woods, both pine and hardwood, in North Carolina, and the quantity of chestnut and tanbark is great enough to give the State high rank in the production of vegetable tanning extracts. A small but necessary activity is the fabrication of shallow tobacco baskets used in marketing the tobacco crop of the State, and nearly 1 million cords of fuel wood was consumed in curing tobacco. The numerous textile mills use thousands of wooden shuttles, some of which are fashioned from blanks made by shuttle-block mills in the mountains and piedmont. Over half a million hewn cross ties are sold to railroads each year. In 1938 the primary forest industries included nearly 3,000 operating plants, and the value of all forest products, including fuel wood, was about $\$ 55,000,000$ (table 22 ).

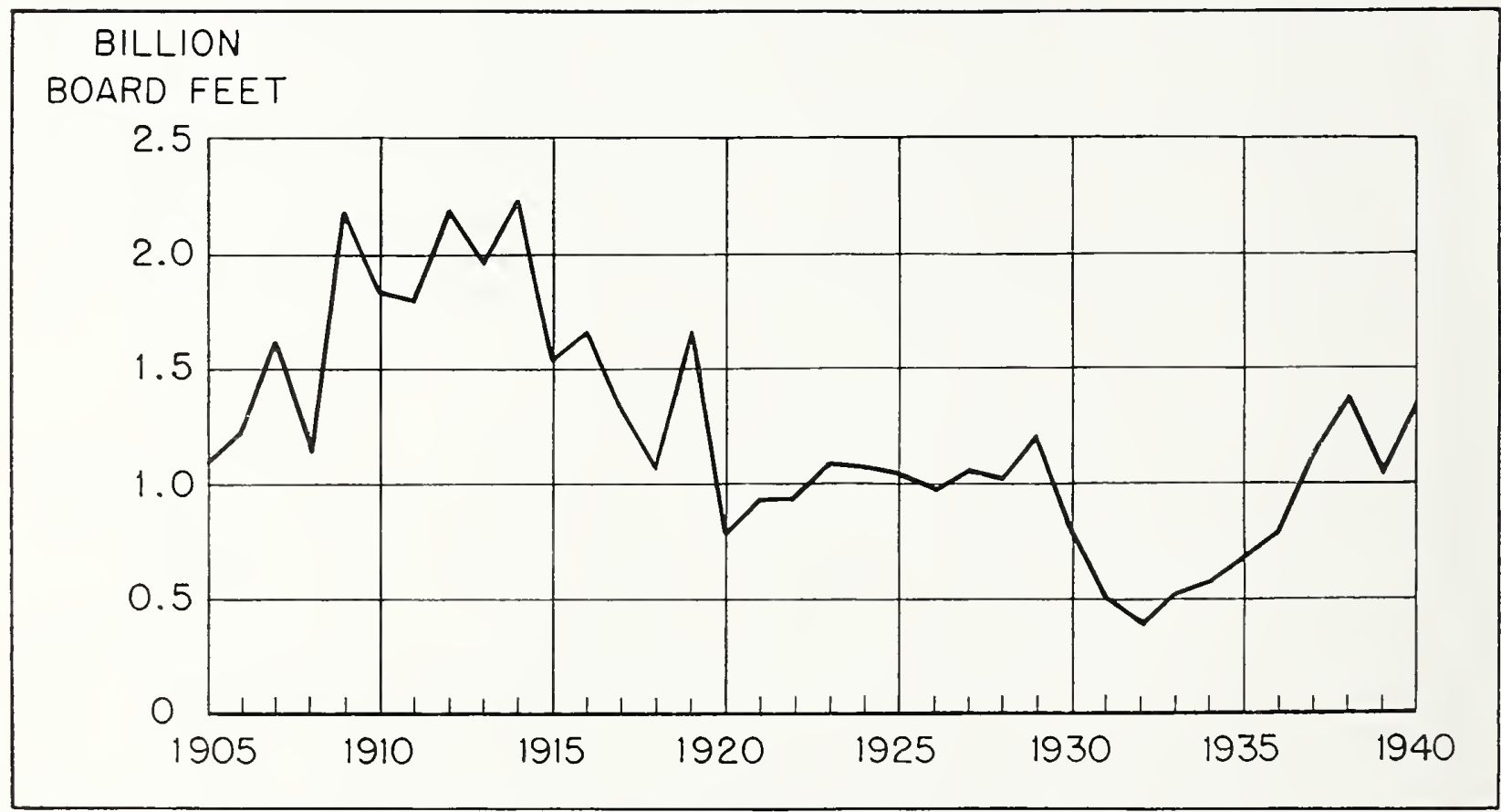

Figure 33.-Lumber production in North Carolina, 1905-70. (1905-36, Bureau of the Census; 1937, Forest Suriey 1938-40, Forest Survey in cooperation with Bureau of the Census.) 

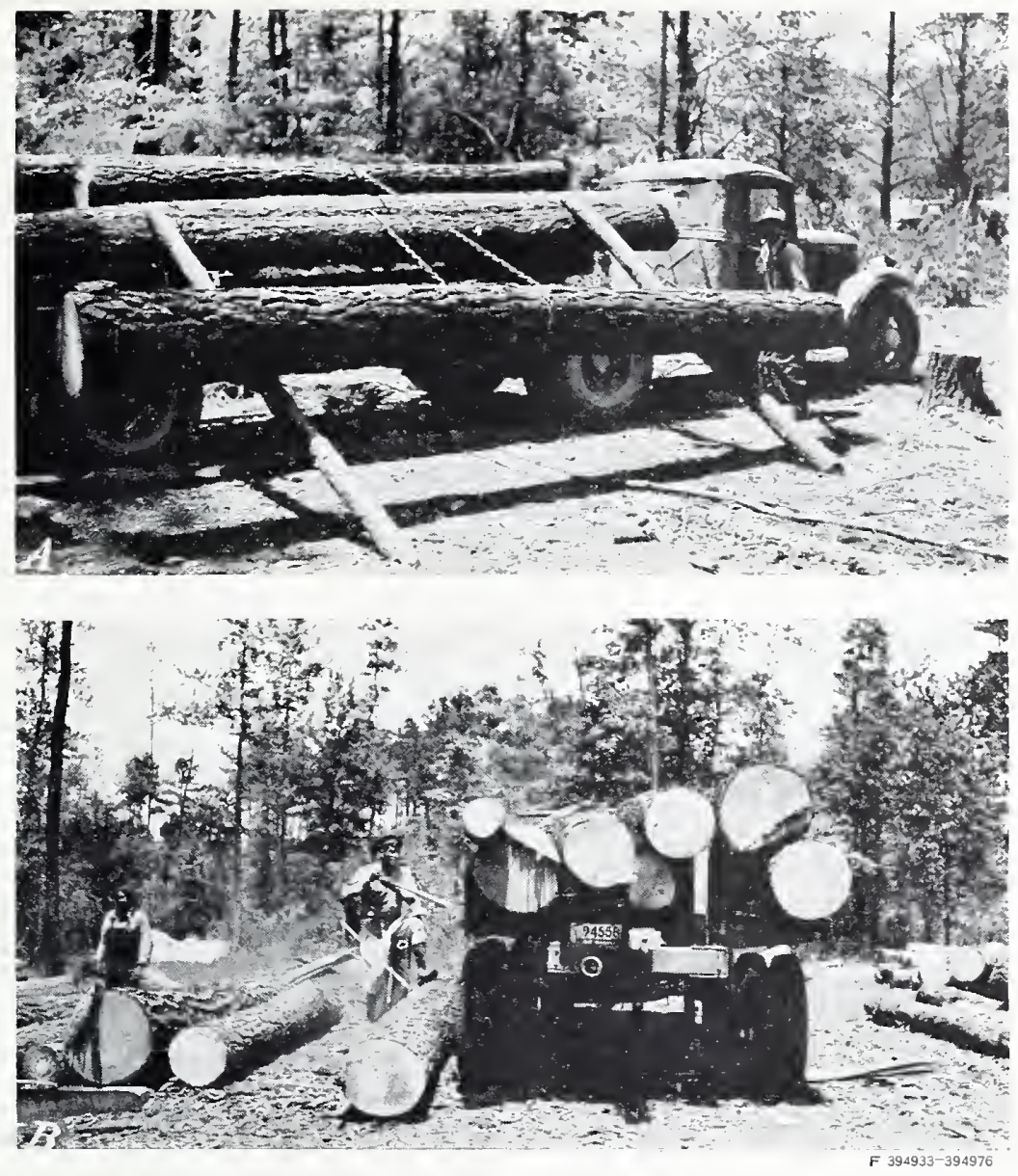

Figure 34.- $A$, Loading pine logs with cross-haul and $(B)$ unloading by hand at sawmill.

TABLE 22.-Production and value of forest products, 19381

\begin{tabular}{|c|c|c|c|}
\hline Product & Plants & $\begin{array}{l}\text { Units pro- } \\
\text { duced or } \\
\text { used }\end{array}$ & Value \\
\hline & Number & $M$ board feet & Dollars \\
\hline Lumber ${ }^{1} \ldots \ldots$ & 2,752 & $1,439,000$ & $26,239,000$ \\
\hline Veneer ...... & 57 & 110,000 & $5,105,600$ \\
\hline 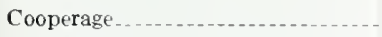 & 10 & 10,500 & 209,500 \\
\hline Dimension stock......... & 34 & 11,300 & 564,300 \\
\hline Shingles........... & 32 & 8,100 & 162,700 \\
\hline & & Pieces & \\
\hline Hewn cross ties.. & & 708,700 & 466,700 \\
\hline Poles, piles, and posts.. & & 159,400 & 304,200 \\
\hline Pulp_ & 4 & $\begin{array}{l}\text { Cords } \\
2405,700\end{array}$ & $7,0-2,300$ \\
\hline Tanning extract & 10 & $\begin{array}{l}2405,700 \\
3186,100\end{array}$ & $\begin{array}{l}, 0,2,300 \\
2,500,000\end{array}$ \\
\hline Fuel wood $4 \ldots$ & & $5,773,000$ & $11,585,100$ \\
\hline Miscellaneous manufacturers 5 & 21 & 14,500 & 421,500 \\
\hline Miscellaneous farm use $\ldots . . . .$. & & 180,900 & 361,800 \\
\hline Total & 2,920 & & $54,992,700$ \\
\hline
\end{tabular}

1 Lumber production includes sawn ties; obtained cooperatively with the Bureau of the Census.

2 Chestnut used for pul p is also included with wood used for tanning extract.

3 Chestnut wood, chestnut oak, and hemlock bark.

Includes 16,600 cords of hardwood distillation wood, and fuel wood pro duced by farmers for their own use.

${ }^{5} 4$ handle, 9 shuttle block, 3 tobaceo basket, 1 insulator pin, and 4 excelsior plants.

\section{The Lumber Industry}

Since 1905 the reported annual production of lumber has averaged about 1.2 billion board feet lumber tally. The 1914 cut, the largest reported, was 2.2 billion feet, and the smallest was 383 million in 1932 (fig. 33). For the 36-year period 1905-40 the aggregate cut was 44 billion board feet, or almost as much as the total volume of saw timber now standing.

The theoretical capacity of the mills operating in 1938 was about 3.5 billion board feet lumber tally, annually computed on the basis of 275 working days of 8 hours each, although many of the smaller mills never operate at capacity for any extended period. If another shift were added, productive capacity would be doubled without operating the several hundred small mills idle in 1938. On the basis of that year's cut of $1 . t$ billion feet, it is obvious there was at least 400 percent excess milling capacity. This need not lead to chronic overproduction, however, because the small mills can readily adjust their output to meet changing conditions, many of them ceasing to operate when markets are poor. 


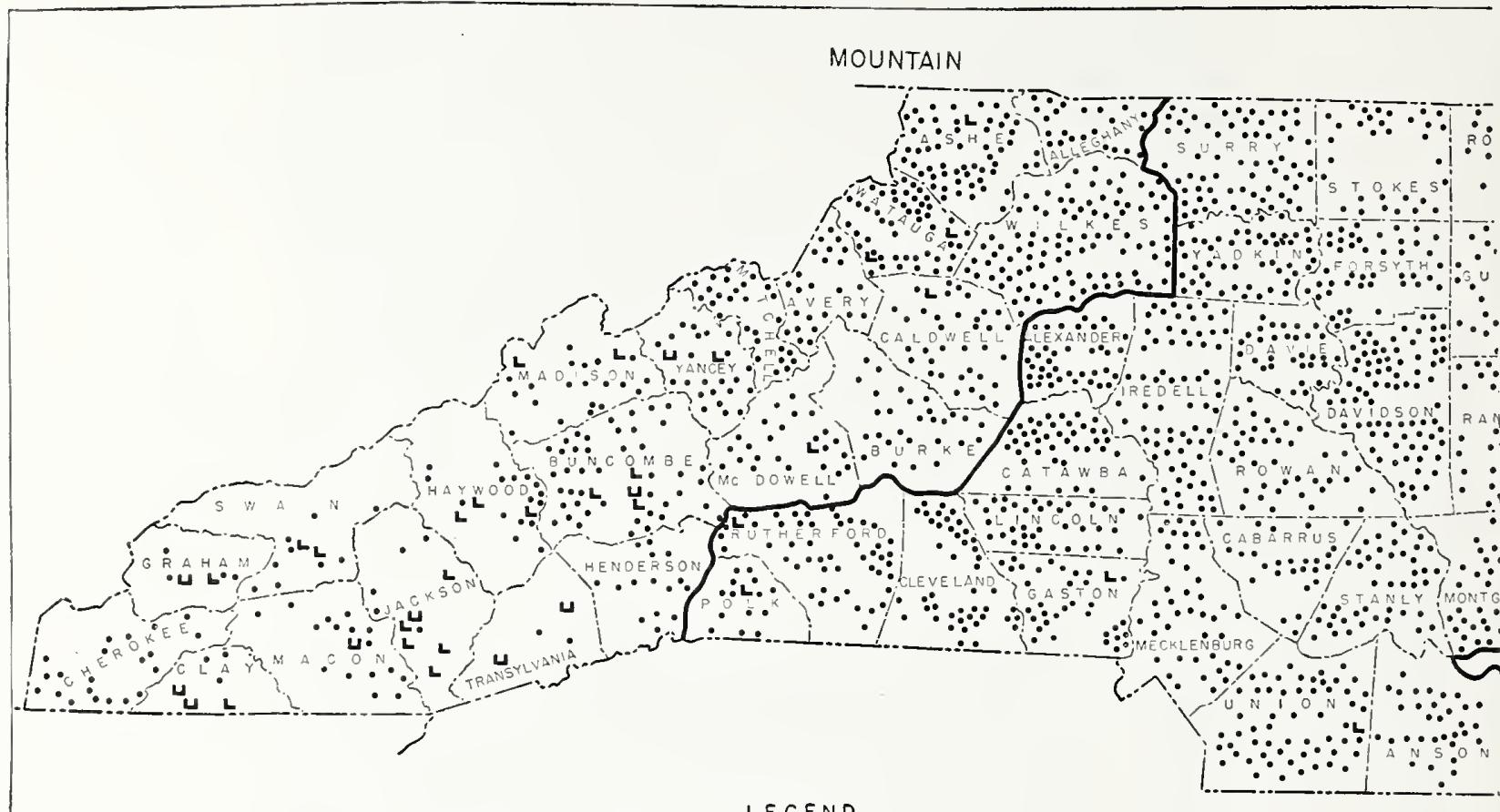

LEGEND

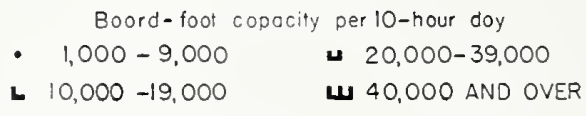

Locotion within counties is opproximote

FIGURE 35.- Location of sawmills

\section{Logging}

Cutting practices vary widely on logging operations in North Carolina, but as a rule a high proportion of the saw-timber volume in trees larger than 10 inches is harvested. The methods of skidding and transporting the logs are not particularly destructive to the growing stock. On most operations the logs are skidded and bunched in the woods by animal power. Tractors are used for skidding on about 10 percent of the operations in the Coastal Plain and piedmont, but they are rarely used in the mountains. In the Coastal Plain skidders are sometimes used to $\log$ the swamps and the less accessible pine land. Light power skidders geared to a truck engine are used on the smaller operations but the larger outfits use steam skidders.

Logs are hauled short distances to the mill with high wheels or wagons, and up to 35 or 40 miles on trucks.
Trucks are used for the long haul on practically all of the operations in the Coastal Plain (fig. 34). Almost one-half of the mills cutting over $20 \mathrm{M}$ board feet per day obtain logs also by water haul and about one-fourth of then use common carrier or logging railroads. In the piedmont the small sawmills are usually set up in the timber tract being logged, and most of the logs are either skidded directly to the mill or hauled to it by team. The larger mills, cutting $10 \mathrm{M}$ to $20 \mathrm{M}$ feet per day, are moved less frequently and logs are carried to most of these by truck. In the mountain region small mills are often set up in the valley bottoms and the $\operatorname{logs}$ skidded by team down the slopes directly to the mills. Trucks are used on the larger operations and a few of the largest hardwood bandsaw mills bring in part of their logs by railroad. Where hauling is necessary, the average distance in the piedmont and mountains is about 3 miles in contrast to 11 miles in the Coastal Plain. 


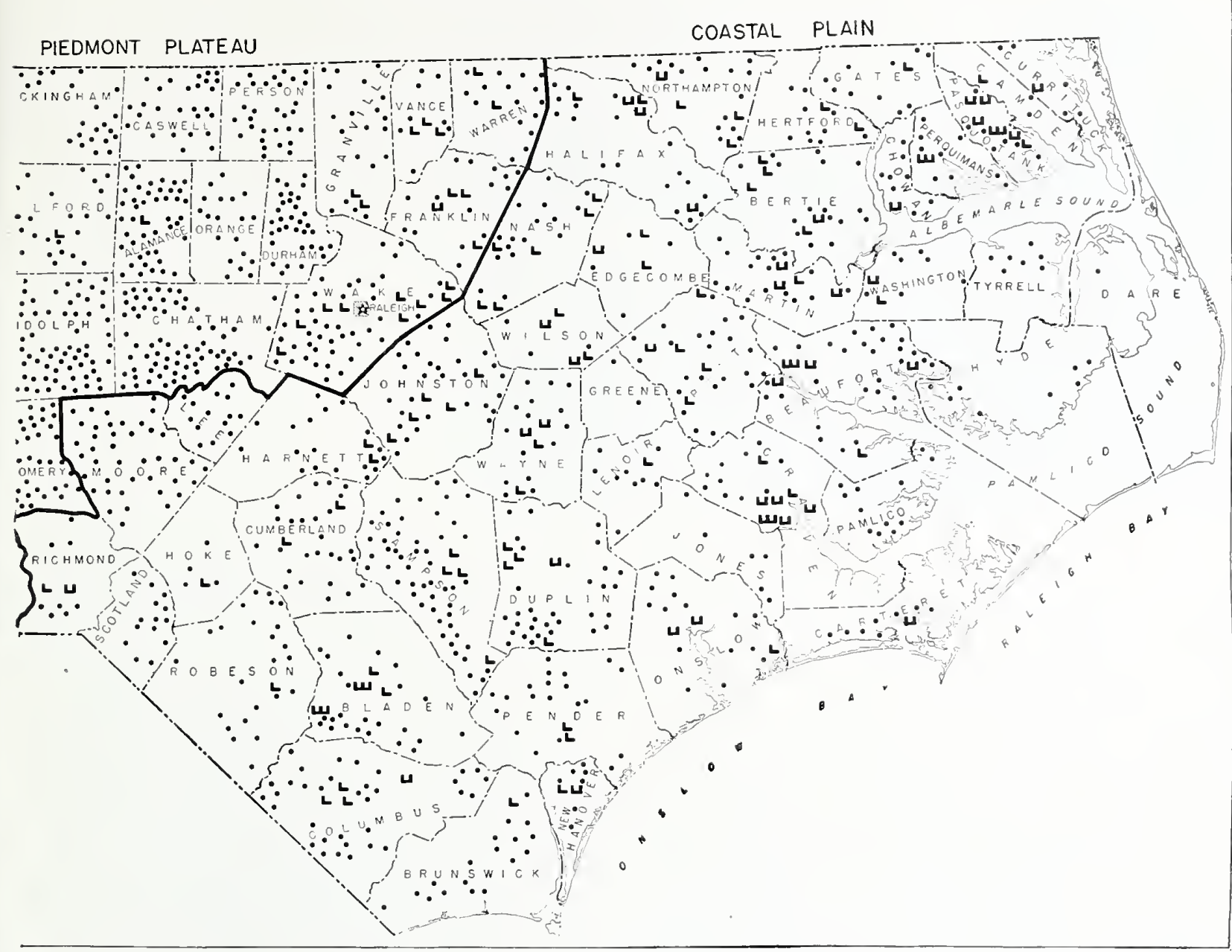

in North Carolina, 1938.

\section{Lumber Mantfacture}

In 1937 the total lumber production in North Carolina, as reported to the Forest Survey, was 1.56 billion board feet; in 1938 it dropped to 1.44 billion (table 23), and in 1939 to 1 billion feet. National-defense orders stimulated lumber production in the latter part of 1940 but the total for the year was only 1.3 billion feet.

The 2,752 sawmills (fig. 35) operating in 1938 have been grouped into four classes on the basis of production per 10-hour day. The 2,588 small portables or "ground mills," equipped with circular saws only, have a cutting capacity of less than $10 \mathrm{M}$ board feet per day and an average production of less than $500 \mathrm{M}$ feet per year (fig. 36). They are characteristically underpowered, utilizing old automobile engines, or small Diesel, gasoline, or steam units. The rough lumber they produce is trucked from the woods to concentration yards for finishing and final distribution. Such mills dominate the industry in the
TABLE 23. - Tumber of mills and lumber production, by region and species group, 1937 and 1038

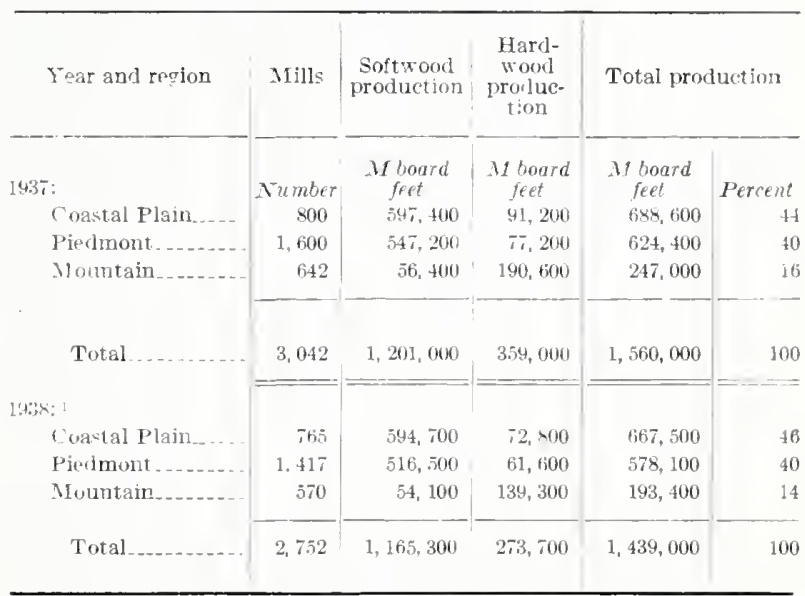

1 Compiled from data ohtained cooperatively with the Bureau of the Census for mills cutting wore than $50 \mathrm{M}$ board feet per ye ar. 


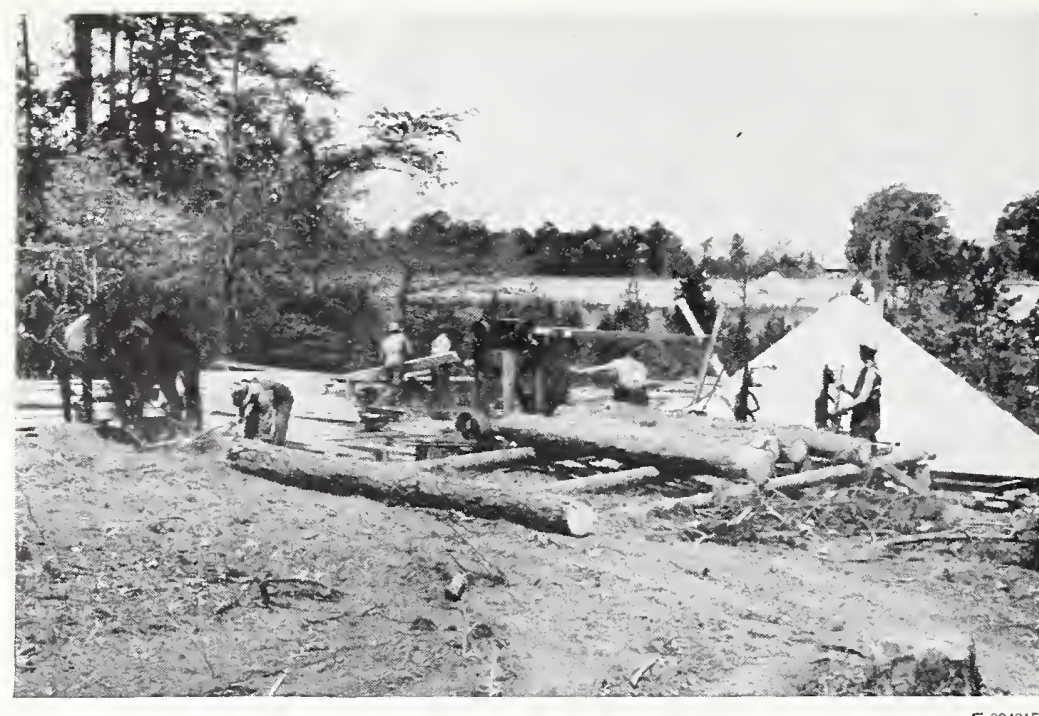

TIGURE 36.-Portable sawmills of this type sawed 70 percent of the lumber in 1038.

piedmont, where in 1938 they sawed over 90 percent of the lumber. About 70 percent of the State's lumber cut was produced by small sawmills (table 24).

TABLE 24.-Lumber production by region and mill capacity class, 1937 and 1938

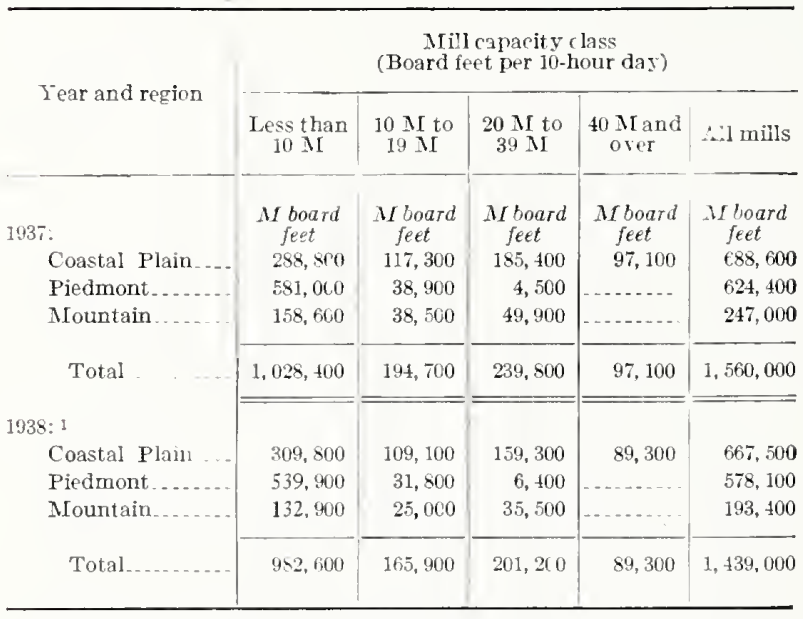

1 Compiled from data ot tained cooperatively with the Bureat of the Census for mills cut ing wore than $50 \mathrm{M}$ board feet ror year.

Closely akin to the small portables are the 114 mills with a cutting capacity of $10 \mathrm{M}$ to $19 \mathrm{M}$ board feet per day and an annual production of 1,000 to $2,000 \mathrm{M}$ feet. The smaller mills in this size class are moved frequently and their mode of operation is similar to the small portables. The larger mills with production approaching $20 \mathrm{M}$ feet per day are usually semipermanent; logs are hauled from the logging operation by truck, or purchased delivered at the mill yard. Over half of the mills of this class are located in the Coastal Plain, where they cut 16 percent of the lumber; as a whole they account for 11 percent of the State cut. Circular saws are the usual epuipment, although a few of the permanently located plants have band saws. About three-fourths of the mills of this class in the Coastal Plain operate planers, but in the piedmont and mountains the proportion is less than one-fourth.

The 45 mills cutting between $20 \mathrm{M}$ and $39 \mathrm{M}$ feet per day are located in the Coastal Plain and mountain divisions. The Coastal Plain mills cut about two-thirds pine and onethird hardwoods and average about 6 million board feet per year, or one-fourth of the regional total. They have a full complement of manufacturing equipment, including dry kilns, and their general organization provides for efficient utilization of second-growth timber. About half of their logs are purchased delivered and the rest are obtained as stumpage. The 9 largest sawmills in the mountain region are hardwood mills of this size class. All but 2 are band mills and their product is chiefly unfinished hardwood lumber. In 1938 they cut about one-fifth of the lumber produced in the mountain region, but it is probaable that some of these mills will cease operating within the next decade as the old-growth timber on which they depend is gradually depleted.

In 1938 there were in North Carolina only five operating sawmills with a capacity of $40 \mathrm{M}$ board feet or more per day. All were situated in the Coastal Plain at or near Elizabethtown, New Bern, Washington, Hertford, and Elizabeth City, respectively. Their capacity ranged from $40 \mathrm{M}$ to $125 \mathrm{M}$ board feet per 10-hour day, and their annual cut varied from 9 to 25 million board feet per mill. This output amounted to 13 percent of the lumber cut in the Coastal Plain, but only 6 percent of the State total. 
TABLE 25.-Lumber production and value at mill, by species group, 1938

\begin{tabular}{|c|c|c|}
\hline Species group & Production & Value \\
\hline Yellow pine ${ }^{1}$ & $\begin{array}{c}\text { Thousand } \\
\text { board feet } \\
1,054,500\end{array}$ & $\begin{array}{c}\text { Dollars } \\
18,000,000\end{array}$ \\
\hline Mixed oak & 122,500 & $2,674,900$ \\
\hline Chestnut & 37,300 & 672,500 \\
\hline "Cypress" - & 30,500 & 795,700 \\
\hline Yellow poplar.. & 30,400 & 720,200 \\
\hline Black and water tupelo. & 26,000 & $4+5 \overline{3}, 800$ \\
\hline Sweetgum & 23,800 & 434,900 \\
\hline Hard and soft maple & 12,100 & 349,200 \\
\hline White pine & 11,400 & 233,400 \\
\hline Hemlock . . & 5,500 & 104,200 \\
\hline Ash & 3,600 & 103,100 \\
\hline Red cedar and white-cedar & 3,600 & 1555,300 \\
\hline Basswood_............. & 3,200 & 102,500 \\
\hline Hickory & 1. 900 & 37.600 \\
\hline Bireh .......... & 1,500 & 45,600 \\
\hline Beech & 800 & 17,100 \\
\hline Sycamore ...... & 300 & 5,800 \\
\hline Walnut & 300 & 23,500 \\
\hline Undetermined & 69,800 & $1,267,700$ \\
\hline Total & 1.439 .000 & $26,239,000$ \\
\hline
\end{tabular}

1 Mainly loblolly and shortleaf, with some longleaf pine and minor amounts of other species.

\section{Value of Lumber}

The total investment in logging equipment and sawmills is approximately $\$ 10,000,000$ or about $\$ 7$ per $\mathrm{M}$ board feet annually cut. With this relatively small capital investment the industry in 1938 manufactured lumber with a value at the mill of over $\$ 26,000,000$ (table 25 ). Yellow pine lumber, chiefly loblolly and shortleaf, accounted for two-thirds of the total value and oak for a tenth.

\section{Distribution of Lumber}

The fact that a large number of the sawmills produce rough lumber and sell it to local concentration yards for planing and grading makes an accurate determination of the lumber distribution difficult. Sawmill records make it appear that a high proportion of the lumber is consumed locally, whereas actually the concentration yards, after assembling it, distribute much of it outside the State. Data obtained in 1938 by the Bureau of the Census in cooperation with the Forest Service indicated that 374 million board feet was sold in other States and foreign countries-probably a conservative estimate and yet equal to one-fourth of the total cut. About 32 million feet was shipped outside the United States and the rest was distributed, as shown in figure 37 , among the States east of the Mississippi River. Pennsylvania, New York, Maryland, Virginia, and New Jersey are the principal markets. Proximity to these centers of consumption gives North Carolina a great advantage over timber-

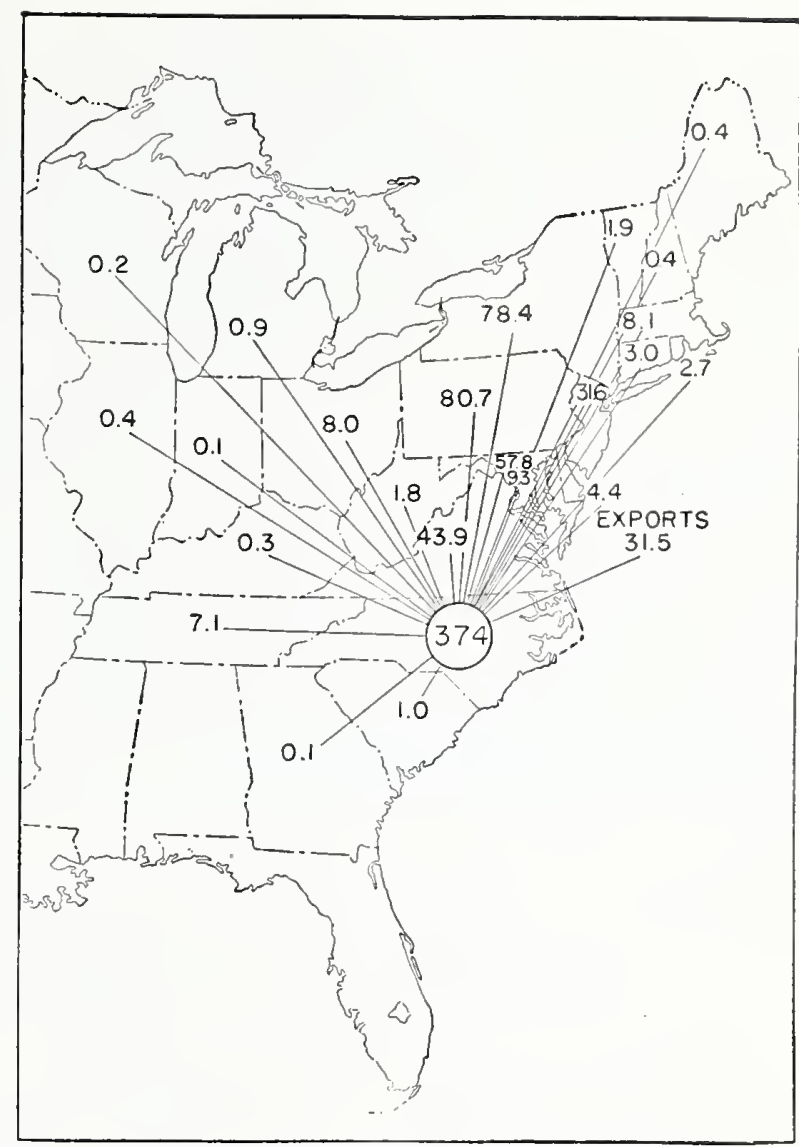

FIGURE 37.-Reported distribution of lumber from North Carolina in millions of board feet, 1938

producing areas on the Pacific coast and in the deep South. The rail rate per $M$ feet of 2,500 pounds was recently $\$ 6.75$ from Raleigh, N. C., to Philadelphia, Pa., and $\$ 8$ to New York. To ship lumber from the Douglasfir region to the Atlantic coast normally costs about $\$ 20$ per $\mathrm{M}$ feet by rail and about $\$ 12$ by water.

\section{Other Forest-Products Industries}

The following discussion of individual industries and statistics of plant operations, production, and rawmaterial consumption attempts to give a picture of the nonlumber forest industries as of 1938. The locations of plants in that year are given in figure 38.

\section{Veneer}

The veneer industry has grown steadily in North Carolina since 1905 to a total of 57 plants, operating at about 85 percent capacity, and using 110 million board feet of logs. The value of the veneer, before its conversion into plywood or concainers, was about $\$ 5,000,000$. On!y in Washington and Florida is the industry on a larger scale. 

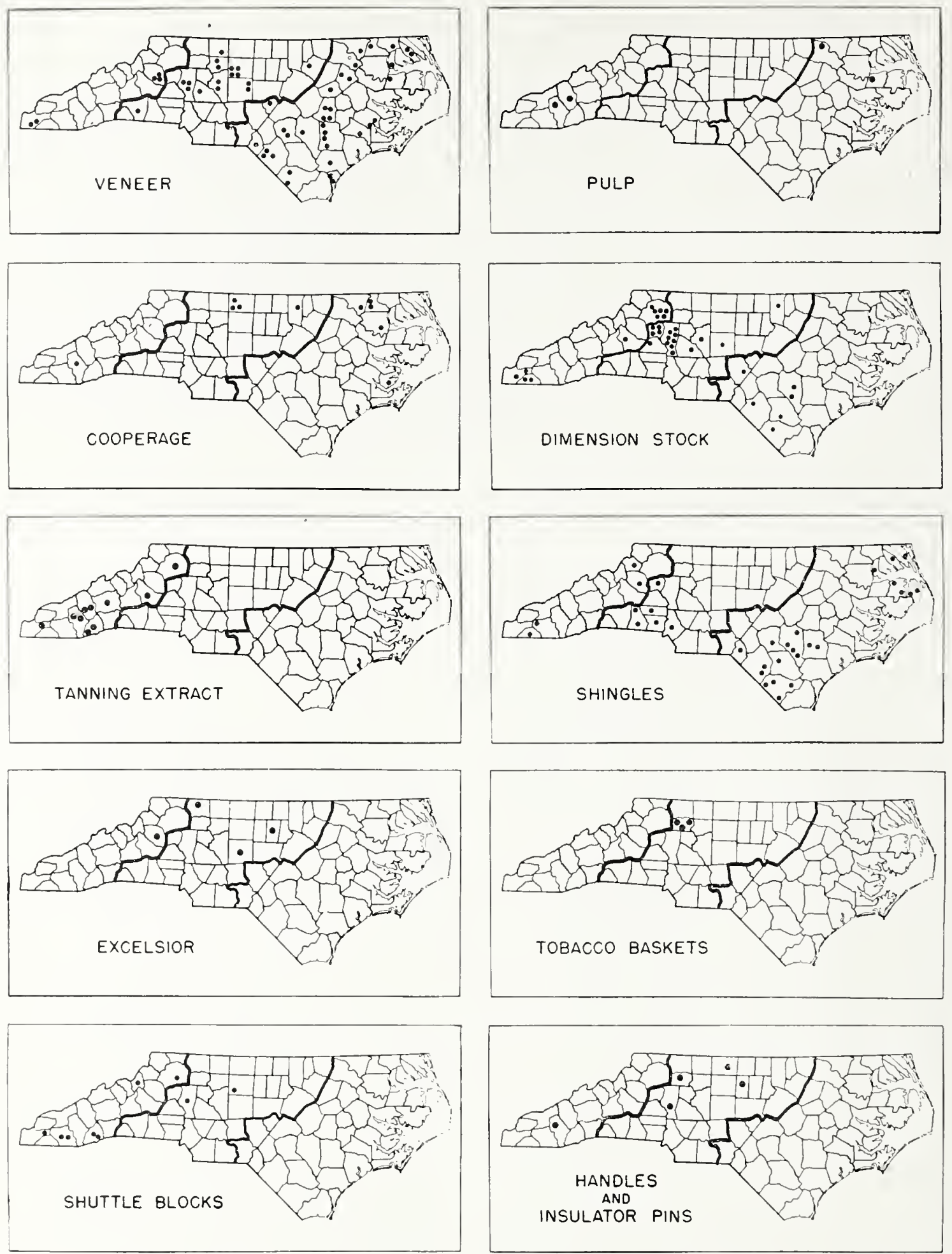

FIGURE 38.- Approximate location of primary nonlumber forest industrial plants in North Carolina, 1938. 
Figure 39.-In 1938 more than t,000 men were employed in the 57 seneer plants in the State.

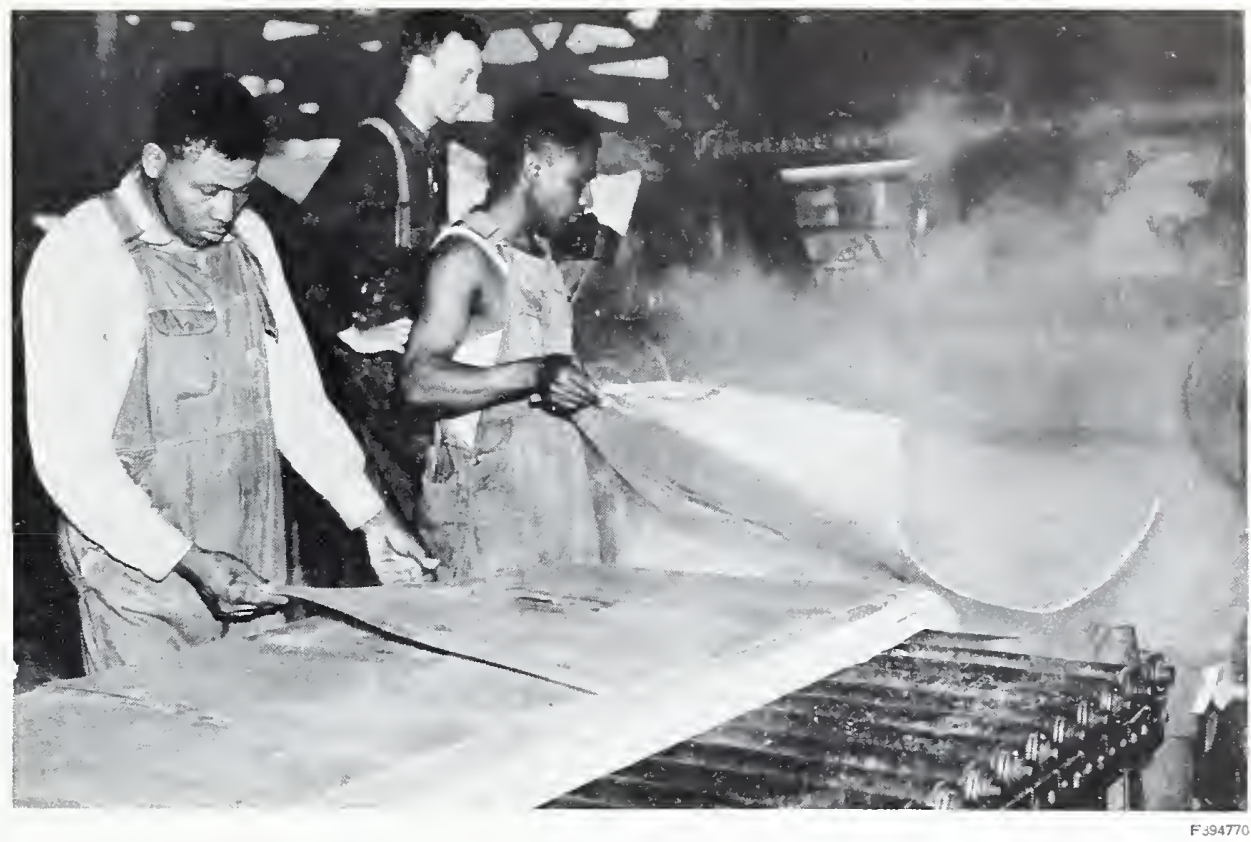

Nearly all the veneer is sold locally, largely to the furniture industry. About 600 million square feet of this semifinished product is manufactured in a year by 38 plants, which use 71 million board feet of bolts. The bolts average 18 inches in diameter and are chiefly yellow poplar, sweetgum, black and water tupelos, and white oak. The average 1938 price paid for bolts was $\$ 25$ per M board feet delivered at the plant.

To provide materials for packaging the truck crops and fruit that are grown in considerable quantity in the State, 19 plants manufacture package veneers (fig. 39). They use in a year some 39 million board feet of bolts, in making about 300 million square feet of veneer. Black and water tupelos, sweetgum, and loblolly pine are the principal species used and the bolts average 12 to 16 inches in diameter.

The veneer industry will probably continue to expand. The State already has a high rank in the manufacture of wooden household furniture and the continued growth of this industry increases the market for veneer. The demand for container veneers is at present gaining enormous im. petus from war demands. Before the war emergency, it appeared to be paralleling the increase in the acreage of truck crops, which has been almost 50 percent in the past decade. If the active veneer plants operated 2758 -hour days per year, they would consume about 130 million board feet of bolts and increase their production about 15 percent. Wood supplies are adequate for an even greater consumption, particularly if more of the high-grade logs are devoted to this use instead of to lumber. Highquality yellow poplar is scarce in the territory of some plants, but in the Coastal Plain there is a great quantity of black and water tupelos suitable for veneer.

Pulp

In 1941 there were four plants in North Carolina manufacturing wood pulp. One at Roanoke Rapids started production in February 1909, and was the first mill to manufacture sulfate pulp commercially in the United States; it was also the first to use southern yellow pine in the sulfate process. Another was established at Canton in 1907 and 30 years later was making sulfate, bleached sulfite, and soda pulp as well as a great variety of papers. A third plant was a sulfate pulp mill, constructed at Plymouth in 1937; in 1940 additions, including new equipment doubled its capacity. The fourth is a semichemical plant at Sylva.

According to Post's Paper Mill Directory of 1941 the combined 24-hour capacity of these four establishments is 710 tons of sulfate pulp, 150 tons of soda, 125 of sulfite. and 70 of semichemical, a total of 1,055 short tons of pulp. This is about 3 percent of the national pulp-mill capacity, but gives North Carolina tenth place among the pulp-producing States. The milis operated at two-thirds of capacity in 1938, making pulp valued at about $\$ 7,000,000$ exclusive of the value of paper manufactured at Canton and Syiva.

Operating 310 days per year, normally considered to represent full capacity, these four plants could produce about 327,000 tons of pulp, using approximately 650,000 standard cords of wood. They used 406,000 cords in 1938 , and paid for it about $\$ 2,500,000$. Sixty-six percent of the 
wood was pine and hemlock, 27 percent was chestnut, and 7 percent was mixed hardwoods. Three of the plants use 5-foot wood measured in 160-cubic-foot units; one plant buys 128-cubic-foot standard cords. Most wood within a 40 -mile radius of the plants is hauled by truck; railroads are used for distances up to 200 miles. The plant at Plymouth obtains some wood by barge haul. Wood is usually procured by the contract system, whereby the company contracts with several individuals who agree to deliver stat ${ }^{-}$ ed amounts of wood at the contract price. The contractors assume the responsibility for locating, buying, cutting, and delivering the wood to the plant. This system relieves the company of many details of bargaining, supervision, and transportation, but experience has shown that some contractors have caused considerable forest devastation and have frequently paid the landowner less than a reasonable price for the standing timber. The progressive pulp and paper companies in North Carolina and elsewhere in the South have recognized the trend of public opinion and the urgency of assuring a permanent supply of raw material, and they are accordingly taking steps to improve timberprocurement practices.

\section{Tanning Extract}

In the mountain region chestnut wood and chestnut oak and hemlock bark are used by an active tanningextract industry. Of the 10 plants making extract in 1938 , two of the largest producers, the pulp and paper mills at Canton and Sylva, produced it as a by-product. According to the Bureau of the Census, the total extract output in 1935 had a value of $\$ 2,600,000$, more than one-half that of all chestnut and oak extract made in the United States. In 1938 the 10 plants used 168,600 cords of chestnut wood and 17,500 cords of hemlock and chestnut oak bark. This includes the chestnut used by the 2 mills making both extract and pulp, and to that extent duplicates the pulpwood consumption estimate. The wood requirements for capacjty operation of the 10 plants are about 292,000 cords of chestnut and 25,000 cords of bark.

\section{Dimension Stock}

Small dimension stock consists of billets or blanks sawed or split to specified widths and thicknesses and to specified lengths less than the ordinary commercial minimum of 8 feet. In 1938 there were 34 small mills manufacturing dimension stock for sale to local furniture factories. They were distributed throughout the State (fig. 38) but were most numerous in the piedmont. Their total consumption in 1938 was about 11 million board feet, or an average per plant of only $3 \mathrm{M}$ board feet per day. At capacity opera- tion for 275 days a year the mills could consume about 30 million feet. Those in the Coastal Plain used black tupelo almost exclusively; those in the piedmont and mountain divisions used white oak, hickory, yellow poplar, maple, ash, birch, and beech. Most of the logs were bought delivered at the mill, and at least three-fourths of them were cut from second-growth timber. The value of the furniture squares produced in 1938 was about $\$ 565,000$.

\section{Fuel Wood}

As indicated in table 22, more wood is used each year for fuel than for any other purpose. The $5 \frac{3}{4}$ million cords consumed in 1938 was three-fifths pine and two-fifths hardwood. Home-grown wood used on the farms makes up the greater part of the total, but the cutting and distribution of fuel wood as a commercial enterprise is of considerable importance. The previously mentioned survey in cooperation with the Bureau of Agricultural Economics indicated that in 1937 farmers sold fuel wood from their farms worth 1.3 million dollars while other farmers paid $\$ 680,000$ for wood, chiefly for curing tobacco. The consumption was distributed as follows, according to Fores $t$ Survey data:

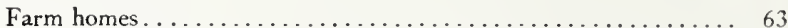

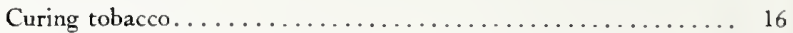

Rural nonfarm homes......................... 14

Schools, small commercial establishments, city ho mes........ 7

Total. ............................ 100

The average farm family used 12.2 cords of wood per year for cooking and heating, rural nonfarm families averaged 4.8 cords, and city families 2 cords. Tobacco curing required on the average 1.9 cords per 1,000 pounds of tobacco and the total volume used was 900,000 cords. Approximately half of all the fuel wood was obtained in 1938 from sawmill slabs, cull trees, and tops, limiting the fuel-wood drain upon the sound-tree growing stock to just under 3 million cords.

\section{Minor Products}

Of the 10 cooperage plants operating in the State in 1938 at about 85 percent capacity-5 in the Coastal Plain were making heading and slack cooperage out of pine, 2 in the piedmont were turning out pine staves for tobacco hogsheads, and 3 upland plants were making tight cooperage from white oak. The value of staves and heading produced was about 1 percent of the value of all cooperage produced in the United States.

The 32 shingle mills, which are small and migratory and consequently difficult to assay accurately, manufactured 


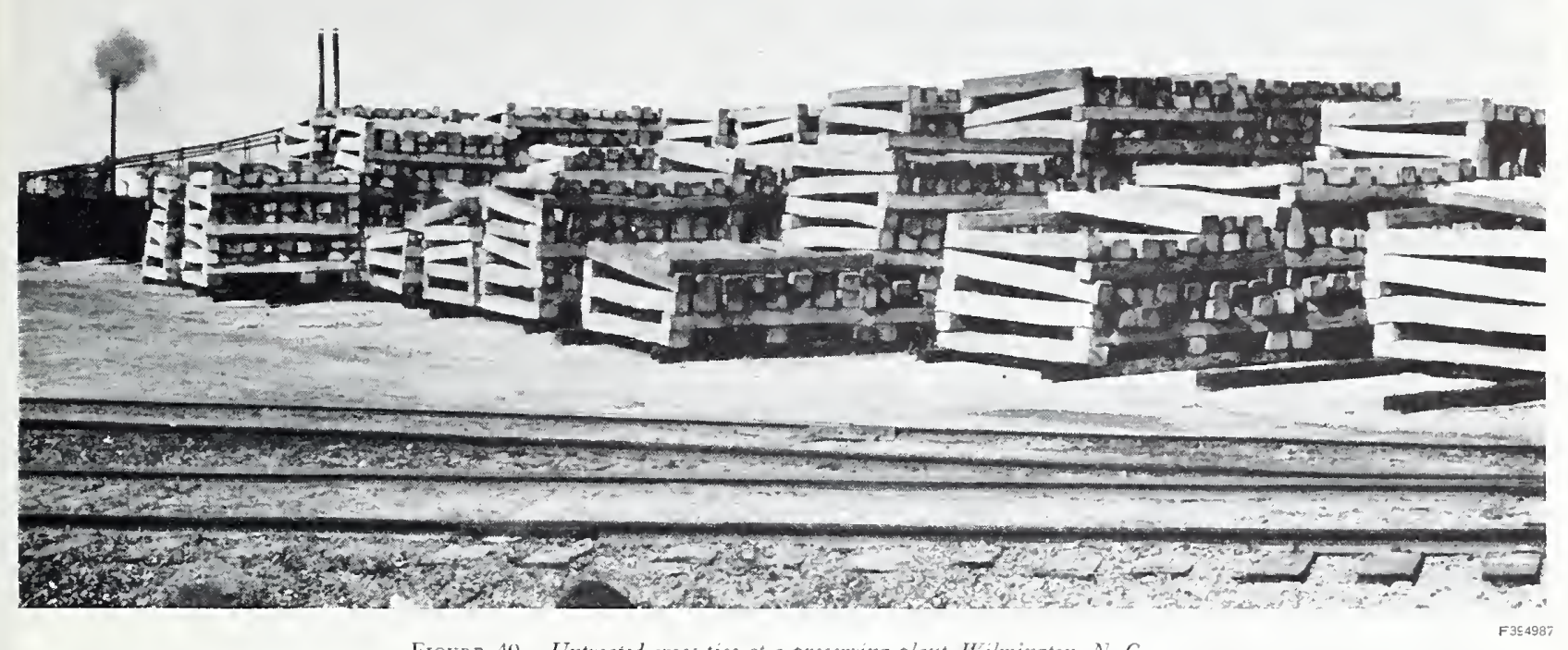

Figtre 40.-Untreated cross ties at a presering plant, Wilmington, N.C.

in 1938 approximately 50,000 squares in all. Mills in the Coastal Plain utilized white-cedar and baldcypress, and sold chiefly to wholesalers, jobbers, and retail lumber dealcrs; those in the piedmont made pine shingles on a custom basis for local use. The typical mill made about 10,000 shingles per 8-hour day.

About 612,500 hewn cross ties were sold to public-carrier railroads in 1938 (fig. 40). Of these, 516,000 were red and white oak, 67,500 were baldcypress, and only 29,000 were pine. The purchasers included nearly 40 railroads. The additional 96,200 ties were purchased by logging railroads in the State.

Treating plants in Portsmouth and Norfolk, Va., and Wilmington, N. C., purchased nearly all of the 151,000 poles and piles produced during 1938. All but 3 percent of these were pine. About 8,000 black locust fence posts were cut in the mountain region for railroad use and some 400 white-cedar posts were cut in the coastal swamps.

Some of the hickory timber in the piedmont goes into the manufacture of handles. In 1937 six handle plants were operating, but in 1938 only the four largest plants reported. One plant, using yellow poplar, maple, oak, and ash, made broom and mop handles; the rest made all types of tool handles from hickory stock. In 1938 about 3,600 cords were used.

Shuttle blocks for the manufacture of shuttles were made at nine small specialized mills and one hardwood dimension plant. Dogwood was used in all plants but one, which used beech, birch, and maple. The total consumption of wood was about 1,500 cords, purchased from local farmers. This yielded approximately 600,000 rough blocks, of which a large proportion were shipped to Greenville, S. C., and Charlotte, N. C., for remanufacture.

Tobacco baskets are large, shallow baskets made of handriven oak splits and a rim of sawn lumber. Three plants, all in Yadkin County, assembled about 250,000 of these baskets in 1937 from 5 million splits made by farmers of the surrounding counties, who received about $\$ 45,000$ for their timber and their work. About 1.5 million board feet of red and white oak logs were used. The same consumption was assumed for 1938.

Four excelsior plants used about 5,000 cords of secondgrowth pine and yellow poplar in 1938 and made excelsior valued at $\$ 120,000$. The wood, about 15 percent yellow poplar, is purchased by the cord delivered at the mill yard. The average daily capacity is 5 cords, which works up into about 5 tons of excelsior.

A few hundred cords of oak were used by a plant making insulator pins, and other hardwood consumption included 20,000 cords shipped to distillation plants outside the State, and 181,000 cords used for fence posts and other farm maintenance. The value of all these products was about $\$ 1,150,000$.

\section{Summary}

In 1938 about 11 million cords of wood, including saw timber and fuel wood, was consumed by the primary forest 
products industries in North Carolina, but because of the use of cull material for fuel this volume is about 3 million cords more than the actual drain upon the sound-tree-growing stock. Half of this volume was used commercially and the rest for fuel wood. Of the $\$ 55,000,000$ valuation given in table 22, lumber, pulp, veneer, tanning extract, and other primary products accounted for $\$ 43,000,000$; and fuel wood and rough farm-construction material for $\$ 12,000,000$. Commercial-wood consumption was only 43 percent of capacity requirements, estimated to be approximately 12 million cords for the plants operating in 1938 .

\section{Employment}

About two-thirds of the 23,000 people employed in the forest-industrial plants (table 26) were in sawmills, and nearly one-half in sawmills cutting less than $10 \mathrm{M}$ board feet per day. Many of the small mills operate only between crop seasons or when lumber prices are high, the employment they provide being irregular and in many cases underpaid. Paying 30 cents or less per hour, such small mills produced rough lumber for a labor cost of about $\$ 6.25$ per M feet, including woods work. At 38 of the larger mills, according to the North Carolina Department of Labor, the average hourly earnings in March 1941 was 36 cents. At this rate the labor cost for woods and mill work was about $\$ 12$ per $M$ board feet for graded lumber.

TABLE 26.-Employment in the primary forest industries, 1938

\begin{tabular}{|c|c|c|c|c|}
\hline \multirow{2}{*}{ Produet } & \multirow{2}{*}{$\begin{array}{c}\text { Plant em } \\
\text { ployees } \\
\text { (number) }\end{array}$} & \multicolumn{3}{|c|}{$\begin{array}{c}\text { Employment-in thousands } \\
\text { of 8-hour man-days }\end{array}$} \\
\hline & & $\begin{array}{l}\text { At the } \\
\text { plant }\end{array}$ & $\begin{array}{l}\text { In the } \\
\text { woods }\end{array}$ & Total \\
\hline Lumber............ & 14,560 & 2.311 & 2,148 & 4.459 \\
\hline Veneer & 4.020 & 816 & 299 & 1.115 \\
\hline Cooperage....... & 100 & $2 \pi$ & 45 & 72 \\
\hline Dimension stock & 270 & 38 & 25 & 63 \\
\hline Shingles . . . . . . . . . & 70 & 33 & 13 & 16 \\
\hline Hewn cross ties.... & -..... & .... & 109 & 109 \\
\hline I'oles and piles...... & $\ldots$ & .... & 47 & 47 \\
\hline Pulp & 2. $\times 00$ & 840 & 475 & 1,315 \\
\hline Tanning extract & 760 & 226 & 262 & 488 \\
\hline Fnel wood & $\ldots$ & $-\ldots$ & 7,417 & $\tau, 417$ \\
\hline Miseellaneous manufactures _.... & 230 & 48 & 47 & 95 \\
\hline Miscellaneous farm use... & ...... & $-\ldots$ & 230 & 230 \\
\hline Total & 22,810 & 4,339 & 11,117 & 15,456 \\
\hline
\end{tabular}

Labor requirements in the 57 veneer plants operating in 1938 were relatively high, approximately 22 man-hours per $\mathrm{M}$ board feet of bolts made into veneer, or 60 manhours for complete fabrication into plywood or containers. Expenditures for labor were therefore $\$ 20$ to $\$ 25$ for each 1,000 feet utilized. The plant employees received a total of nearly $\$ 3,000,000$ in wages.

The four pulp mills provide more man-hours of work per unit volume of wood than any other major forest industry, and a high proportion of the workers are skilled. In March 1941, the average earnings of the pulpmill workers were 72.6 cents per hour, the weekly rate of $\$ 31.58$ being the highest in manufacturing industries reported to the North Carolina Department of Labor. In 1938 the wage scale was lower, and the total pay roll was about $\$ 3,000,000$.

The remaining forest-industrial plants gave employment to approximately 1,400 people. At 30 cents per hour the wage income was $\$ 858,500$ or $\$ 600$ per worker per year.

Seventy-two percent of the total forest employment was wonds work, which included felling, sawing into merchantable lenghts, and transporting the timber to the place of consumption. Of the 11 million man-days of labor required to harvest the wood consumed during 1938, 7.6 million were expended in the production of fuel wood and other material for farm use. Nearly $3 \frac{1}{2}$ million man-days went into the production of sawlogs, veneer bolts, cross ties, poles, pulpwood, and other industrial products, or the equivalent of 260 days per year for 13,500 men. The actual number of persons employed in woods work is unknown, but at least 14,750 were engaged in logging for sawmills.

The amount of employment provided by the forestproducts industries in North Carolina is generally underestimated because a majority of the plants are small and much of the woods work is a part-time activity of farmers and other rural residents. The 15.5 million 8-hour mandays required in 1938 to cut, haul, and manufacture the raw material obtained from the forests would have been sufficient to employ 59,000 workers for a work year of 260 days. If, however, the labor expended in the procurement of noncommercial fuel wood and other farm needs is excluded, the strictly commercial activities in the woods and mills would have required 30,000 full-time employees. Many more people, in reality, obtained part or all of their income through woods and mill employment. If hourly wages averaged 25 cents in 1938 , the total forest-industry pay roll was about $\$ 14,000,000$. 
N O R T H C A R O L I X A F O R E S T R E S O U R C E S A A

\section{Forest Increment and Commodity Drain}

i:

OLARLY the forest-products industries constitute a valuable part of the economic structure of North Carolina. The forest resource upon which they depend is extensive, but unless the net increment equals or exceeds the average drain upon the forest, the industries must eventually decline for lack of raw material. The following is an attempt to evaluate the net increment and commodity drain as of 1938 .

\section{Forest Increment}

\section{Diameter Growth}

Diameter growth of individual trees is the basis for reckoning all forest increment. To obtain the maximum increment per acre a proper balance must be maintained between quantity of growing stock and rate of growth of single trees.

ТАВLE 27.-Average annual diameter growth in 10 years of selected species, by diameter-class groups

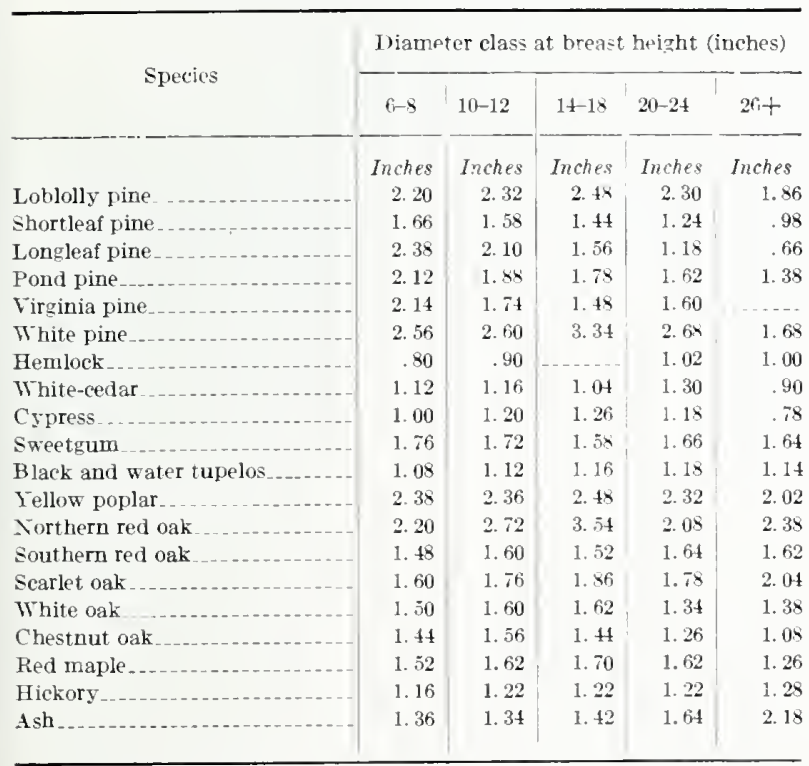

${ }^{9}$ Reference should be made to the Growth and Drain section of Definitions of Terms Used in the appendix, p. 70.
North Carolina has a variety of rapid-growing trees. Of the 20 species listed in table 27 , northern red oak, eastern white pine, yellow poplar, and loblolly pine increase in diameter at the highest rate. White oak, desirable for many purposes, grows relatively so slowly that in some stands it may be more profitable to favor the faster-growing northern red oak. Because of its abundance, high value, merchantability, and rapid growth rate, loblolly pine is the premier species of North Carolina. Under good conditions it grows to minimum saw-timber size in about 35 years and continues to increase in diameter an average of 0.25 inch per year until maturity. Virginia and pond pine make rapid diameter growth while young, but slow down after they reach 10 inches in diameter. Shortleaf is the slowest growing of the native pines.

\section{Net Increment Per Acre}

Because of wide variations in stand classification of the forest growing stock, there are marked differences in the average annual net change in volume per acre, ranging from an actual loss to an increase of 344 board feet (table 28).

The loblolly pine type is the most productive, and the net increment of 206 board feet was the average for 4.6 million acres, 26 percent of the forest land. On the 1.5 million acres of this type in the second-growth uncut condition the net annual increment averaged 344 board feet per acre. In contrast, the upland hardwoods type, which occupies nearly 4 million acres, had an average net increment of only 67 board feet. This is partly a result of poor sites and slow growth rates, but a more important factor is the small volume of growing stock per acre, averaging less than 1,500 feet for the type area. The white pine type includes hemlock and the loss in volume in the old-growth partly-cut stands was caused by heavy mortality of residual hemlock trees. This indicates that hemlock in mixed stands should be cut along with the other old-growth timber to avoid the losses likely to result from a disturbance in site conditions. 
TABl.E 28.- Average net board-foot increment per acre, by forest type and forest condition, 1938

\begin{tabular}{|c|c|c|c|c|c|c|c|}
\hline \multirow{2}{*}{ Forest type } & \multicolumn{2}{|c|}{ Old growth } & \multicolumn{2}{|c|}{$\begin{array}{l}\text { Second } \\
\text { growtb } \\
\text { sawlog } \\
\text { size }\end{array}$} & \multicolumn{2}{|c|}{$\begin{array}{l}\text { Under } \\
\text { sawlog } \\
\text { size }^{1}\end{array}$} & \multirow{2}{*}{ 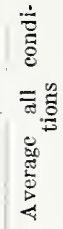 } \\
\hline & 莡 & $\begin{array}{l}\vec{D} \\
\overrightarrow{3} \\
\text { a } \\
A\end{array}$ & 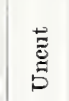 & $\frac{D}{2}=$ & 吾要 & 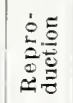 & \\
\hline & Bd.ft. & $B d . f t$. & $B d . f t$ & $B d . f t$. & Bd.ft. & $B d . f t$. & $B d . f t$ \\
\hline Loblolly pine. & 204 & 212 & 344 & 213 & 70 & 8 & 206 \\
\hline Shortleaf pine & 206 & 131 & 263 & 179 & 84 & $I$ & 158 \\
\hline Pond pine $\ldots . . . . .$. & 42 & 75 & 148 & 124 & 42 & 4 & 58 \\
\hline Longleaf pine.... & 73 & 94 & 156 & 133 & 53 & 12 & 62 \\
\hline Virginia pine & 173 & 125 & 218 & 179 & 69 & 1 & 118 \\
\hline White pine & 44 & -79 & 198 & 162 & 69 & & 117 \\
\hline Core hardwoods. & 147 & 78 & 206 & 125 & 54 & 3 & 101 \\
\hline Bottom-Iand hardwoods & 230 & 158 & 214 & 170 & 52 & 4 & 141 \\
\hline Upland hardwoods .... & 88 & 86 & 114 & 100 & 43 & 1 & 67 \\
\hline Average all types & 159 & 132 & 247 & 179 & 58 & 5 & 131 \\
\hline
\end{tabular}

1 Areas so classified contain seattered trees of sawlog or near-sawlog size.

The average net increment per acre for all forest types combined was not large in any of the forest conditions. Uncut stands of second growth averaged 247 bcard feet, but this could be increased to at least 350 feet with proper management. In all the State, 53 percent of the forest land was producing an average of 201 board feet per acre per year, 39 percent was producing 58 board feet, and 8 percent was producing only 5 feet, or an over-all average of 131 board feet. This is distinctly unsatisfactory in view of the latent productivity of the forest land and the increasing demand for timber products.

\section{Net Board-Foot Increment}

In the record of saw-timber increment, mortality, and net increment for 1938 as presented in table 29, mortality in softwoods is 10 percent of increment, in hardwoods 12 percent, and in all species 11 percent. Nearly two-fifths of the resultant net increment of softwoods and one-half of that of hardwoods were attributable to the growth of under-sawlog-size trees into sawlog sizes.

Softwoods made up about 70 percent of the total net increment. In this contribution old-growth softwood timber had little part, both because of the small volume of growing stock and because of the high rate of mortality ( 32 percent) in these mature stands, chiefly of hemlock. Second-growth sawlogs-size stands yielded three-fourths of the net increment. Mortality in this class of timber was not excessive, but there is growing concern over the possible effects of what is called the little-leaf disease, which is causing heavy mortality in young shortleaf pine stands in several counties of the piedmont. Despite intensive study no definite conclusions had been reached by 1941 with respect to its cause or possible methods of control.
$\mathrm{T}_{\mathrm{ABLE}}$ 29.-Increment, mortality, and net increment of saw timber by species group and forest condition, 1938

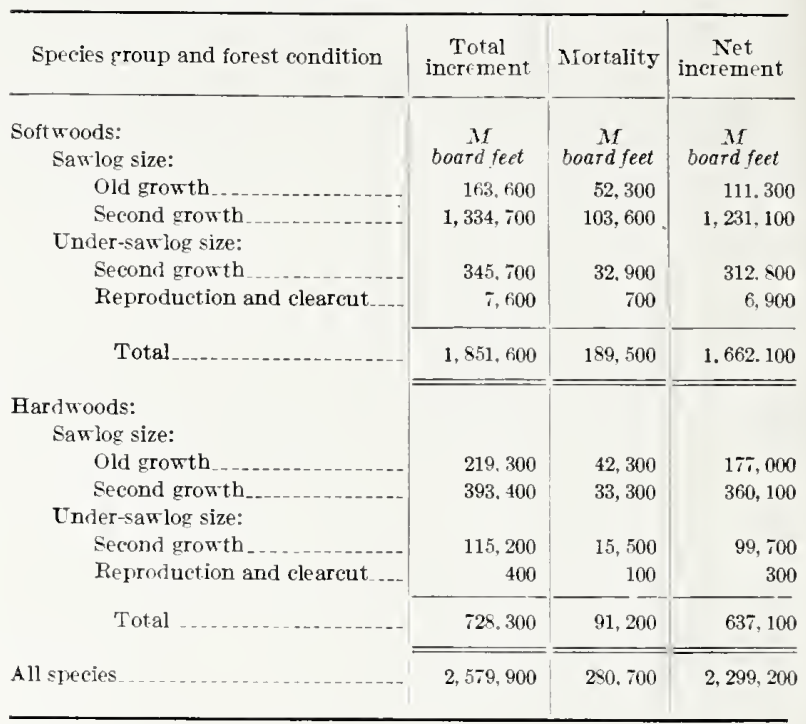

Old-growth timber is more abundant in the hardwoods and mortality lower; such stands produced almost threetenths of the net increment. A large part of this volume is in good-quality bottom-land hardwoods in the Coastal Plain. Nearly three-fifths of the net increment was in second-growth sawlog-size stands. Many of the trees contributing to this volume increase are rather inferior in quality, particularly in the piedmont. Mortality is not conspicuously high in any one forest condition, but in all but old-growth stands losses are proportionately greater in hardwoods than in pine.

\section{Net Increment of the Total Stand}

The 9 million standard cords of net increment of the total stand shown in table 30 is slightly more wood than that consumed in 1938 by all the pulp mills in the United States. About 60 percent of the volume is softwood, the proportion varying from 31 percent in the mountains to 68 percent in the Coastal Plain. The volume increase in cubic volume of 630 million cubic feet was roughly 5 percent of the national wood yield. The forests of the Coastal Plain, occupying about one-half of the wooded land in the State, produced 58 percent of the board-foot increment and nearly 50 percent of the increment of all sound trees. The piedmont and mountain forests do not produce their share of board-foot increment because a high proportion of the stands are below sawlog size. In time they will develop into productive saw-timber stands if they receive fairly adequate management and are protected from exploitative cutting, fire, insects, and similar destructive agencies. 
TABLE 30. -Net saw-timber increment and net increment of the total siand, and species group, 1938

\begin{tabular}{|c|c|c|c|}
\hline Region and speeies yroul, & Saw timber & \multicolumn{2}{|c|}{ All sound trees 1} \\
\hline $\begin{array}{l}\text { Coastal Plain: } \\
\text { Softwoods } \\
\text { Hardwoods }\end{array}$ & $\begin{array}{l}\text { MI } \\
\text { board feet } \\
1,042,200 \\
299,000\end{array}$ & $\begin{array}{l}1,000 \\
\text { cords } \\
3,021 \\
1,417\end{array}$ & $\begin{array}{r}1,000 \\
\text { cubic feet } \\
216,200 \\
93,600\end{array}$ \\
\hline Total $\ldots . .$. & $1,341,200$ & 4,438 & 309,800 \\
\hline $\begin{array}{l}\text { Piedmont: } \\
\text { Softwoods . ...- } \\
\text { Hardwoods...- }\end{array}$ & $\begin{array}{l}514,800 \\
190,600\end{array}$ & $\begin{array}{l}2,117 \\
1,182\end{array}$ & $\begin{array}{r}151,570 \\
75,970\end{array}$ \\
\hline 'Total .. & 705,400 & 3,299 & $22 \bar{\tau}, 540$ \\
\hline $\begin{array}{l}\text { Mountains: } \\
\text { Softwoods } \ldots . . . \\
\text { Hardwoods .... }\end{array}$ & $\begin{array}{l}105,100 \\
14 \pi, 500\end{array}$ & $\begin{array}{l}442 \\
998\end{array}$ & $\begin{array}{l}31,150 \\
61,470\end{array}$ \\
\hline Total...- & $=\quad 252,600$ & 1,440 & 92,620 \\
\hline $\begin{array}{l}\text { All regions: } \\
\quad \text { Softwoods } \\
\text { Hardwoods }\end{array}$ & $\begin{array}{r}1,662,100 \\
63 \pi, 100\end{array}$ & $\begin{array}{l}5,580 \\
3,597\end{array}$ & $\begin{array}{l}398,920 \\
231,040\end{array}$ \\
\hline Total ............ & $2,299,200$ & 9,177 & 629.960 \\
\hline
\end{tabular}

1 The increment of all sound trees 5 inches d. b. h. and larger is expressed in cords with bark and in cubie feet without bark.

\section{Commodity Drain}

The commodity drain on the sound-tree growing stock comprises the wood cut and used within the State and a small quantity shipped to manufacturing plants in nearby States, but not the volume of wood imported from South Carolina, Georgia, Tennessee, and Virginia. These imports included 10 million board feet of veneer, sawlogs, etc., and 78,000 cords of pulpwood.

The drain on the sawlog portions of trees is expressed in board feet, but is included in drain expressed in cords and cubic feet. Drain on hardwood tops and on dead chestnut is not included. All three estimates of drain are summarized in table 31. Fifty-two percent of the commodity drain was on forests in the Coastal Plain division, 37 percent in the piedmont, and only 11 percent in the mountains.

\section{Saw-Timber Drain}

The 2.22 billion feet of commodity drain upon the saw-timber growing stock in 1938 was roughly threefourths softwoods and one-fourth hardwoods. Two-thirds of it was chargeable to the manufacture of lumber and one-fifth to the burning of sawlog material as fuel. Veneer manufacture, ranking after lumber milling industrially, accounted for only 5 percent of the drain, and pulpwood (including distillation wood) less than 3 percent.
TABLE 31.-Commodity drain on growing stock, 1938 SAW-TIMBER GROWING STOCK

\begin{tabular}{|c|c|c|c|c|}
\hline Commodity & Softwoods & Hardwonds & \multicolumn{2}{|c|}{ All species } \\
\hline & $M$ board feet & M board feet & $M$ board feet & Percent \\
\hline Lumber. & $1,210,000$ & 248,300 & $1,458,300$ & 65.6 \\
\hline Veneer & 8,900 & 110,000 & 118,900 & 5. 4 \\
\hline Coolrerage........... & 13,000 & 500 & 13,500 & .6 \\
\hline Dimension stock & 400 & 11,800 & 12,200 & .6 \\
\hline Shiugles ..... & 9,000 & ....... & 9,000 & .4 \\
\hline Hewn cross ties................ & 7,500 & 34,400 & 41,900 & 1.9 \\
\hline Poles and piles....... & 14,100 & negl. & 14,100 & .6 \\
\hline Pulpwood I & $5 \overline{7}, 000$ & 5,000 & 62,000 & 2.8 \\
\hline Fuel wood & 360,400 & 108,900 & 469,300 & 21.1 \\
\hline Miscellaneous manufactures? & 700 & 3,600 & 4,300 & .2 \\
\hline Miscellaneous farm use ${ }^{3} \ldots \ldots$ & 10,500 & 7,700 & 18,200 & .8 \\
\hline All commodities ... & $1,691,500$ & 530,200 & $2,221,700$ & 100.0 \\
\hline
\end{tabular}

ALL SOTND TREES

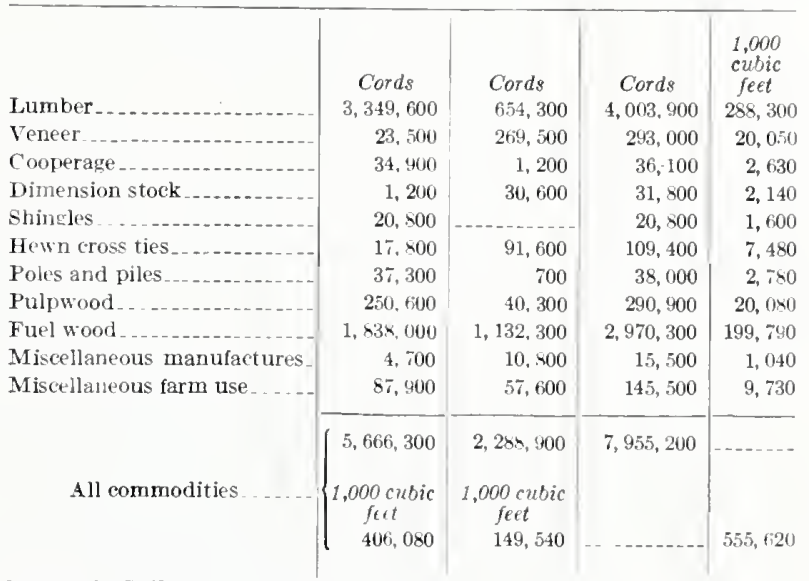

1 Includes distillation woor.

2 Includes handles, shuttle blocks, tobaceo baskets, insulator pins, and excelsior.

3 Includes fence posts eut and used on farms.

45 inches d. b. h. and larger, including saw timber.

Not all of the commodity drain represented utilization within North Carolina. Approximately 86 million board feet of unfinished timber products was purchased by plants in South Carolina, Georgia, Tennessee, and Virginia. Lumber was manufactured from 59 million feet of the sawlogs shipped out of North Carolina, chiefly by sawmills at Norfolk, Suffolk, and Franklin, Va. Nearly 8 million board feet of veneer bolts was sold in Virginia. Cooperage logs totaling 3 million feet were also exported to mills in Virginia.

\section{Total Drain from Sound Trees}

The commodity drain upon all sound trees 5 inches d. b. h. and larger was almost 8 million cords (table 31), of which 71 percent was on softwoods, and 29 percent on hardwoods. Approximately 85 percent of the softwood 
and 60 percent of the hardwood drain was obtained from the larger trees, of sawlog size. Most of the 1.7 million cords of drain upon under-sawlog-size trees was used for fuel wood, but 75,000 cords of small softwoods and 25,000 cords of small hardwoods were cut for pulpwood and distillation wood. Lumber accounted for 50 percent of the total sound-tree drain, fuel wood 37 percent, and veneer and pulpwood each about 4 percent. The drain of sound wood, excluding bark, amounted to $\mathbf{5 5 6}$ million cubic feet.

Of the 7.96 million cords of wood cut from sound trees (table 31), the primary forest industries and domestic consumers within the State used 7,705,000 cords. The remaining 250,000 cords was shipped to adjoining States in rough form. Sawlogs and veneer and cooperage bolts made up part of these intrastate shipments, but pulpwood and distillation wood were also important items. About 72,000 cords of pulpwood and distillation wood was exported, more than half of it to Virginia. The fact that more pulpwood was brought into the State than was shipped out, by more than 5,000 cords, does not indicate any shortage of wood in the State for existing pulp mills.

\section{Comparison of Increment with Drain}

A comparison of net increment with commodity drain affords an opportunity to measure the effect of utilization upon the forest growing stock. It attempts to answer the common question, is the forest increasing as fast as it is being used? If it is, the laborers, landowners, and businessmen of North Carolina can depend upon the forest resource for continued employment, income, and industrial opportunity. If not, North Carolina's thirdranking manufacturing industry will gradually decline to a much lower position.

In analyzing the relation of net increment to commodity drain, several factors should be clearly understood. The drain for 1938, on the basis of the lumber cut, is reasonably close to the average of the past 30 years. Ordinarily, the balance for a single year is apt to differ materially from the long-time trend, owing to fluctuations in both natural and man-caused drains from year to year with changing conditions. The net increment of the forest is also subject to change. In some areas, notably the mountain division, young second-growth stands occupy a high proportion of the forest land. If allowed to grow until they become merchantable they will bring about a significant increase in the saw-timber yields.

Another point to bear in mind is the averaging effect brought about by combining data from the several regions of the State. Actually there are local areas where over- cutting is serious, and there are others where forest industries can expand. Also, in an over-all balance of net increment and drain it is difficult to show the effect of species and diameter changes. In North Carolina, as elsewhere, it is common practice to utilize the largest and best trees, while the trees left to grow are mostly small or of inferior species. Thus even where net increment exceeds drain, serious stand deterioration often occurs, with a decided loss in timber values. Finally, net increment should not be considered a static quantity that will inevitably accrue each year in about the same amount. Serious overcutting, bad fire seasons, or widespread infestations of insects or disease can reduce the annual increment for many years to come. On the other hand, intensive forest management, which includes fire protection, will greatly increase the net increment on all but the poorer forest land.

\section{Saw-Timber Stand}

The decrease of nearly 30 million board feet in the softwood growing stock during 1938 is largely attributable to preventable natural losses. The total increment exceeded commodity drain by 160 million feet but nearly 190 million feet was lost through mortality (table 32 ). In the

TABLE 32.-Comparison of net increment with commodity ${ }^{1}$ drain, saw timber, and total stand, 1938

IN BOARD FEET, INTERNATIONAL 1/4.INCH RULE

\begin{tabular}{|c|c|c|c|}
\hline Item & Softwoods & Hardwoods & All species \\
\hline Growing stock, Jan, 1,1938 & $\begin{array}{c}\text { M board fect } \\
28,673,000\end{array}$ & $\begin{array}{c}\text { M board feet } \\
14,033,700\end{array}$ & $\begin{array}{r}M \text { board feet } \\
42,706,700\end{array}$ \\
\hline Increment.- & $1,8.51,600$ & 725,300 & $2,579,900$ \\
\hline Mortality........ & 199.500 & 91,200 & 280,700 \\
\hline Net increment & $1,662,100$ & 637.100 & 2. 299.200 \\
\hline Commodity drain..... & $1,691,500$ & 530.200 & 2.221 .700 \\
\hline Net change in growing stock & $-29,400$ & 106,900 & $7 \pi, 500$ \\
\hline Grow-ing stock, Jan. 1, 1939 & $2 s, 643,600$ & $14,140.600$ & $42,751,200$ \\
\hline
\end{tabular}

IN CUBIC FEET, INSIDE BARK

\begin{tabular}{|c|c|c|c|}
\hline Growing stock, Jan. 1, $1938 \ldots$ & $\begin{array}{c}1.000 \\
\text { cubic feet } \\
\text { 7. } 3.3 .190\end{array}$ & $\begin{array}{c}1,000 \\
\text { cubic feet } \\
5,437,840\end{array}$ & $\begin{array}{c}1,000 \\
\text { cubic feet } \\
13.321,030\end{array}$ \\
\hline Increment. . & 464.530 & 270.300 & 734,830 \\
\hline Mortality.... & 65,610 & 39,260 & 104,870 \\
\hline Net increment. & 398,920 & 231.040 & 629,960 \\
\hline Commodity drain. & 406,050 & 149,540 & 555,630 \\
\hline Net change in growing stock & $-7,160$ & 81,500 & 74,340 \\
\hline Growing stock, Jan. 1, 1939 & 7.8 .6 .030 & $5,519,340$ & 13. 395.370 \\
\hline
\end{tabular}

1 For detail by physiographic regions and forest condition, see tables 42 and 43, Appendix. 
old-growth stands drain was about three times the net increment, causing a reduction of 215 million feet in the mature growing stock (fig. 41). Net increment of sawlogsize second growth failed to equal drain by 81 million feet. Only in the under-sawlog-size stands was net increment greater than drain; here the difference was 267 million feet. The effect was to reduce the volume of large nature timber and only partially replace it with increment in the minimum saw-timber sizes.

By regions the picture is somewhat different. ${ }^{10}$ In the Coastal Plain an overcut in the softwood old growth of 134 million feet and a surplus of 123 million feet in the sawlog-size second growth, left a net loss in saw-timber stands of 11 million feet. An increase of 131 million feet in the under-sawlog-size timber gave the Coastal Plain softwoods a net increase of 120 million feet almost entirely in the smaller trees. In the piedmont the utilization of softwood was considerably in excess of the timber yield-51 million feet in the old-growth stands and 215 million in the sawlog-size second growth-a deficit that the under-sawlog-size stands failed to compensate fully, the total decrease being 157 million feet. In the mountains old-growth softwoods were reduced in volume, but increases in the second-growth stands resulted in a net increase of 7 million feet. For the State, the decrease in softwood saw timber was 29 million feet.

In contrast to the softwoods, the hardwood board-foot growing stock increased in volume by 107 million board feet for the State as a whole. Old-growth stands were overcut, but an increase in the sawlog-size second growth produced a net gain of 21 million feet. Although the volume relation of net increment to commodity drain is more favorable in the hardwoods, quality deterioration of the growing stock is considered more serious there than in the softwoods. The hardwood cut is concentrated on the relatively few species particularly desirable for major use, leaving the little-used hickories and low-grade oaks to produce a major share of the increment. Also in certain species, such as sweetgum, there is a wide disparity in value between old-growth and second-growth timber. Old-growth sweetgum, called red gum in the lumber trade, sells for about 40 percent more than secondgrowth "sap gum." This situation is in general reflected in the individual records for the three physiographic divisions, even in the piedmont, the only region in the State where old-growth hardwoods increased; much of this mature timber has been left standing in partly cut stands because it is a less desirable kind. In the mountain division the overcutting, especially of 49 million feet in the old-growth timber, has, however, especial significance.

\footnotetext{
${ }^{10}$ The totals cited here are given in table 42 in the Appendix, p. 75.
}

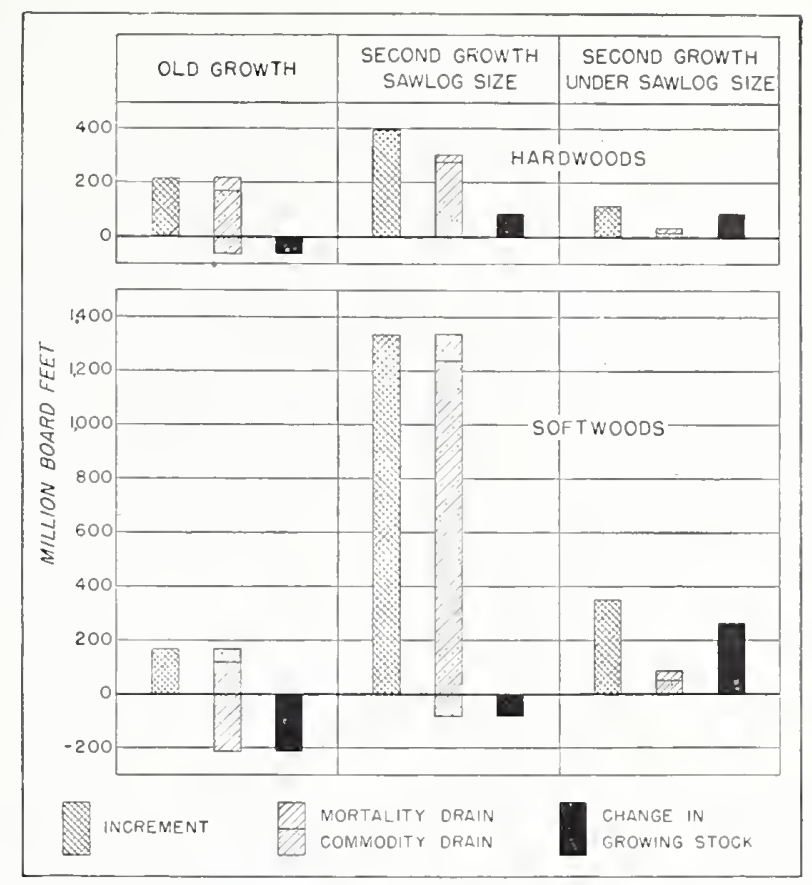

FIGURE 41.-Comparison in board feet of increment with mortality and commodity drain by forest contition, 1938.

Several of the larger mills in this part of the State are practically the only support of the neighboring towns, and positive action is required to save the industries and dependent communities from gradual disintergration. The Forest Service, with its timber resources on the Pisgah and Nantahala National Forests, probably can make the most concrete contribution toward solving the problem.

\section{Total Stand}

The effect of increment, mortality, and commodity drain upon the total stand, or sound-tree growing stock 5 inches d. b. h. and larger, is summarized by cords in figure 42 and by cubic feet in tables 33 and 43 . The increase of 74 million cubic feet in the total stand was all in the hardwoods, for the softwood stands decreased by 7 million cubic feet. This softwood decrease occurred throughout the full range of tree sizes in both the old-growth and second-grow th sawtimber stands of softwood. Only in the young secondgrowth stands was there a volume increase of both sawlogand under-sawlog-size trees. The volume of smaller trees in the saw-timber stands was reduced, by reason of the heary commodity drain and the irregular distribution of the stand in the smaller diameter classes. More 2and 4-inch trees are needed to assure an unbroken accretion of trees to saw-timber sizes, for at present the volume annually moving out of the 5- to 8.9-inch diameter group is greater than the volume recruited from 2 - and 4 -inch 


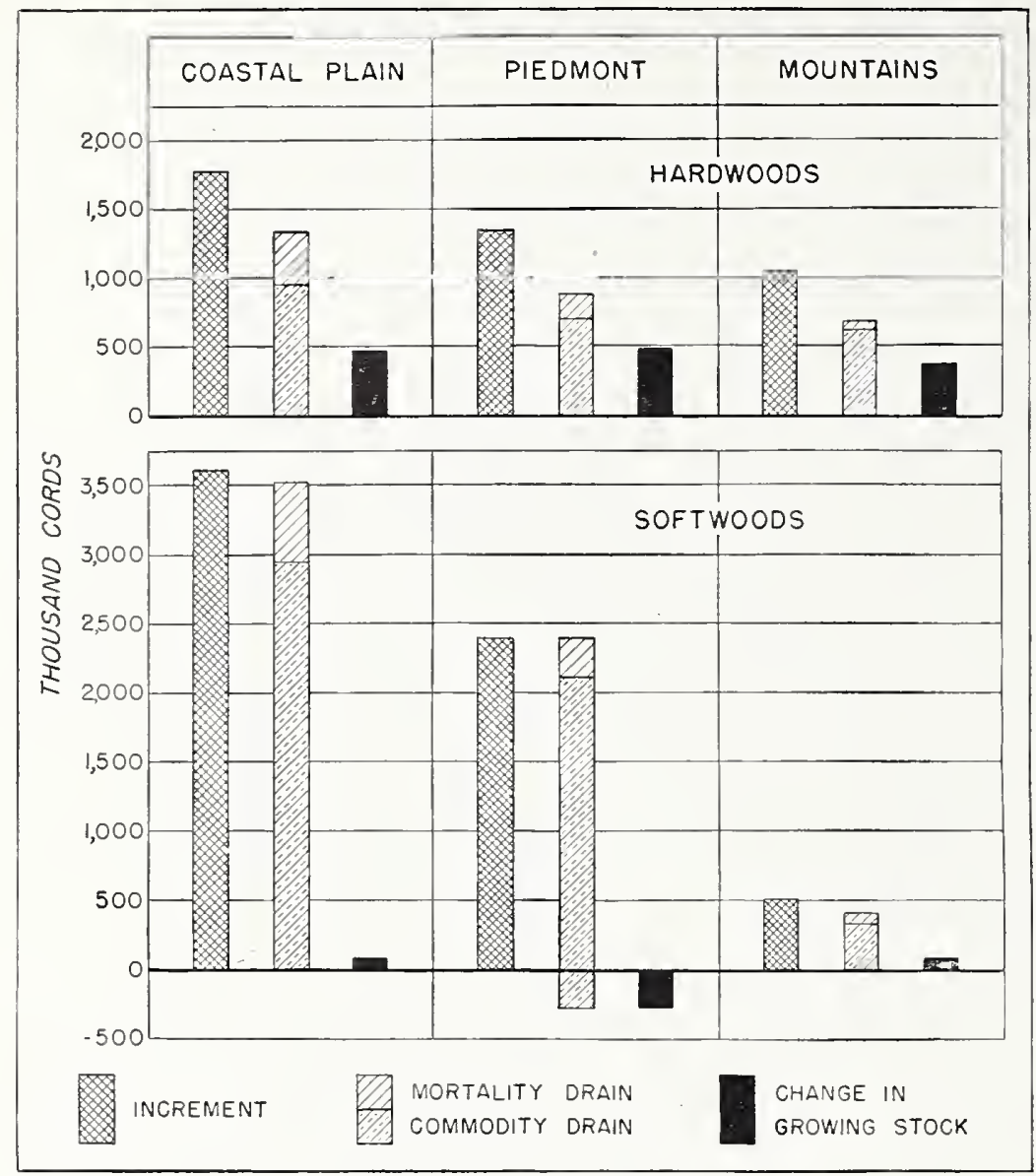

Figure 42.-Comparison, in cords, of increment with mortality and commodity drain in the Coastal Plain, piedmont, and mountains, 1938.

trees. They can be obtained by leaving more seed trees, by planting, and especially by more intensive fire protection.

$\mathrm{T}_{A B L E}$ 33.--Change in growing stock, by forest condition and diameter group, 1938

\begin{tabular}{|c|c|c|c|c|}
\hline \multirow[b]{2}{*}{$\begin{array}{l}\text { Species group and diameter } \\
\text { class (inches) }\end{array}$} & \multirow[b]{2}{*}{$\underset{\text { growth }}{\text { Old }}$} & \multicolumn{2}{|c|}{ Second growth } & \multirow[b]{2}{*}{$\begin{array}{l}\text { All endi- } \\
\text { tions }\end{array}$} \\
\hline & & $\begin{array}{c}\text { Sawlog } \\
\text { size }\end{array}$ & $\begin{array}{c}\text { Under } \\
\text { sawlog } \\
\text { size }\end{array}$ & \\
\hline & $\begin{array}{l}\text { 1. } 000 \\
\text { cubic } \\
\text { feet }\end{array}$ & $\begin{array}{l}\text { 1, } 000 \\
\text { cubic } \\
\text { feet }\end{array}$ & $\begin{array}{l}\text { 1, } 000 \\
\text { cubic } \\
\text { feet }\end{array}$ & $\begin{array}{l}\text { 1, } 0000 \\
\text { cubic } \\
\text { feet }\end{array}$ \\
\hline \multicolumn{5}{|l|}{ Softwoods: } \\
\hline $5-8.9 \ldots \ldots$ & $-1,890$ & $-52,040$ & 42,970 & -10.960 \\
\hline 9 and over. & -43.460 & $-10.0 \times 0$ & 57,340 & 3,800 \\
\hline Total_ & $-45,350$ & $-62,120$ & 100,310 & $-7,160$ \\
\hline \multicolumn{5}{|l|}{ Hardwoods: } \\
\hline $5-12.9$ & 9,310 & 21,160 & $2 \bar{\tau}, 190$ & $5 \pi .660$ \\
\hline 13 and over & $-9,380$ & 17,090 & 16.130 & 23.940 \\
\hline Total & -70 & 38. 250 & 43.320 & 81,500 \\
\hline All species. & $-45,420$ & $-23,870$ & 143,630 & 74,340 \\
\hline
\end{tabular}

The aggressive and less-utilized hardwoods increased by 81 million cubic feet. The greatest volume increase was in trees less than 13 inches in diameter, but the sawlog-size trees increased appreciably in all but the old-growth stands of the Coastal Plain and mountains, where there were an increase of only 1.6 and a reduction of 7 million cubic feet, respectively.

In the Coastal Plain the softwoods increased by 79,090 cords, chiefly in sawlog-size trees. Hardwoods increased in all forest conditions, although most of the gain of 463,000 cords was in second-growth saw timber. Softwoods in the piedmont decreased in the saw-timber stands and increased in the younger stands, resulting in a net deficit of 264,000 cords. Hardwoods increased in all classes of timber, but most of the gain was in undersawlog-size stands. Although old-growth softwoods in the mountains decreased by 88,000 cords, second-growth stands increased by four times as great a volume. Most of the increase was in small, immature trees, however, that will not take the place of the older, merchantable timber for several decades. 
Obviously the increment and drain situation is different in each region of the State and a further refinement would bring out local differences within regions. For the State, the interplay of losses and gains resulted in a decrease of 86,000 cords in the softwood growing stock, and an increase of $1,300,000$ cords in the hardwood growing stock.

\section{Change in Growing Stock, 1937-4I}

In the 4-year period from January 1, 1937, to January 1, 1941, the entire saw-timber growing stock increased 0.7 percent, with both the softwoods and hardwoods showing a slight increase (table 34). Drain upon the softwoods exceeded net increment in every year but 1939, however, while hardwood drain exceeded net increment only in 1937. In 1941 the demand for construction lumber and other forest products useful in the war effort increased the board-foot drain by an estimated 20 percent above 1940 and the volume of saw-timber growing stock on January 1, 1942, was probably reduced to nearly the 1937 level.

The increase in the cubic-foot growing stock, all sound trees 5 inches d. b. h. and larger, amounted to 1.9 percent in 4 years, but even at this rate it would take aver 100 years to double the growing stock. All of the increase was in the hardwoods. In addition to usual demands, the softwoods have been subject to an increasing cut of pulpwood by mills in this and adjoining States, and in 1939 the quantity of wood used for curing tobacco was above the average. As a result the total softwood stand at the beginning of 1941 was less than in 1937.

TABLE 34.-Change in growing stock, 1937-1941

IN BOARD FEET, INTERNATIONAL $1 / 4-$ INCH RULE

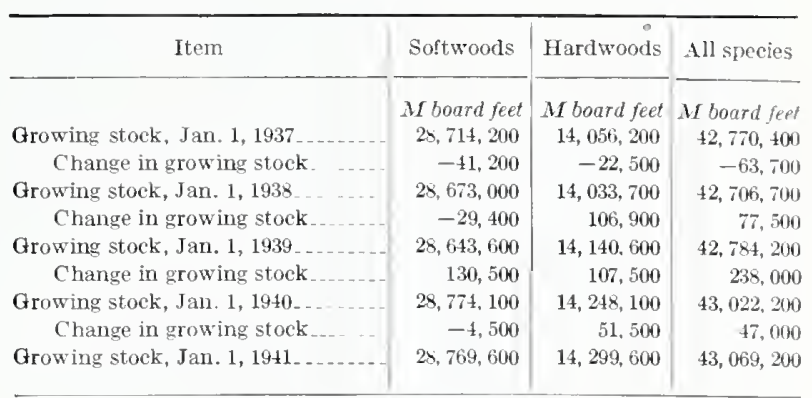

IN CUBIC FEET, INSIDE BARK

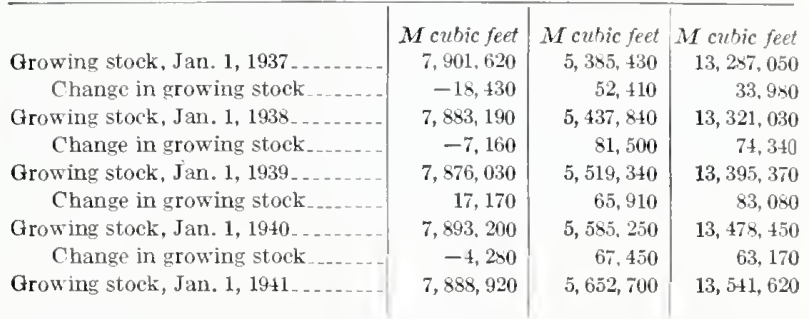




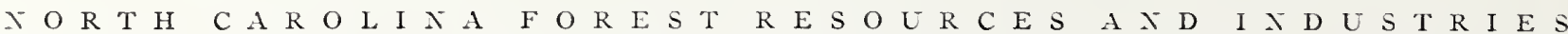

\section{Opportunities for Increasing Utility of the Forest Resource}

$\because \cdots$ «?

$\mathrm{T}$

HE forest situation discussed in the preceding sections does not give cause for great optimism. 'True, the State has an extensive, fast-growing timber resource and a diversified, active wood -products industry, but the facts point toward a growing strain on the timber supply which if allowed to continue will have an adverse effect upon forest industries, land use, employment, and economic conditions generally.

Sound conservation principles dictate that the forest growing stock be maintained at a high level, the timber resource be used no faster than it grows, and the annual increment available for removal be of satisfactory quantity and quality. In North Carolina the softwood timber is being reduced in both quantity and quality and the hardwood timber is being reduced in the species, sizes, and grades most in demand. Correction of these conditions will increase the usefulness of the forest resource on a permanent basis.

\section{Develop the Forest Stand}

The greatest opportunity for increasing the utility of the forest lies in building up the stand.' This is primarily a task of developing and putting into effect sound practices of forest management adapted to the requirements of profitable timber utilization. The objective of these practices should be to increase the volume and improve the quality of the growing stock while developing the most satisfactory methods of harvesting the timber crop. Farm woodlands, containing over one-half of the forest land, need improvement as much as industrial timberlands do, or more. Actually, they present a better opportunity for successful development; the use of cull material and low-value species for fuel wood and rough construction on the farm make it easier to increase production of high-grade material.

\section{Increase Volume}

The usual prescription for building up the volume of growing stock calls for a reduction of the cut below the productive capacity of the forest. In theory this will accomplish the desired result, and it does so on managed forests in stable ownership; but on a State-wide area of 18 million acres, in thousands of ownerships, such control is practically impossible under the existing laissez-faire policy. Expanding markets for timber, rising prices, fire and insect losses, and changes in land use practices are a few of the unpredictable factors that may increase wood consumption or reduce timber volume and increment.

The forests of North Carolina are, in general, productive enough to justify a more positive approach. Instead of trying to reduce the cut, with consequent reductions in employment and income, emphasis should be placed upon increasing the growing stock while keeping the cut at the present level until increased yields warrant an expansion of wood use. This will require public financial aid and legal recognition of the need for conservative cutting practices to insure more complete restocking to desirable species. It will require protection of reproduction and young second growth from logging damage, adequate fire prevention and control measures, and public encouragement and assistance in planting abandoned fields, clearcut land, and thinly stocked stands. North Carolina will miss a great opportunity if it fails to insure the general adoption of these constructive practices.

\section{Improce Quality}

The potential utility of North Carolina's forests will never be realized as long as 16 percent of the total sound wood volume is in cull trees of limited merchantability. In 1938 there were 44 million cords of wood in cull trees, chiefly hardwoods, representing a reduction in forest productivity of 15 to 25 percent. Even as scattered trees throughout the forest, they occupy useful growing space and reduce the total area of productive forest land by an aggregate of nearly 4 million acres, measured by the area required for an equal volume of sound trees. The greatest 

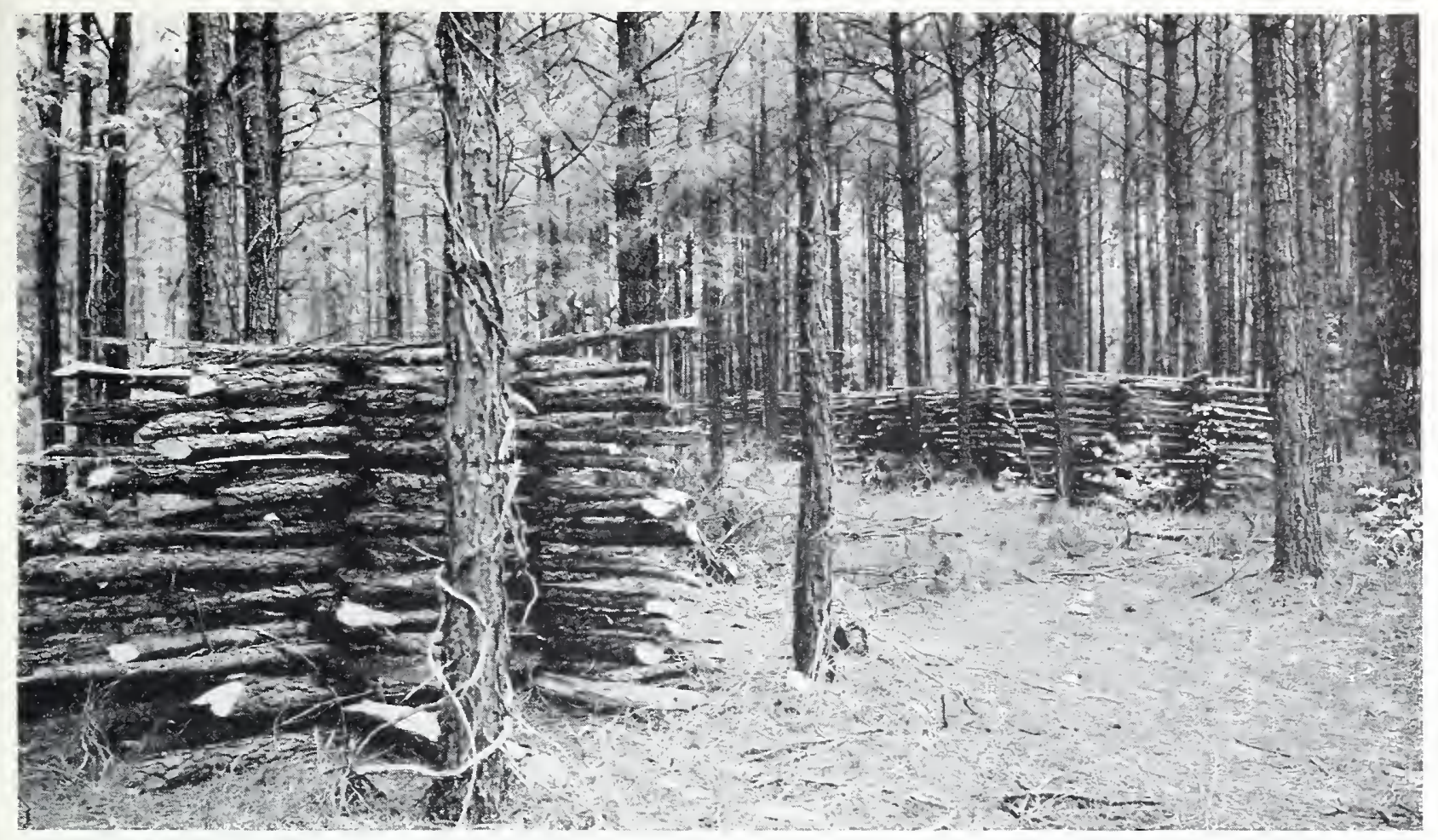

FIGURE 43.-Old-ficld stand of shurtleaf pine in Orange County thinned for fucl wood.

F394754

opportunity for improvement exists in the mountain and the Coastal Plain divisions, but more cull material can be cut for fuel wood in farm woodlands throughout the State.

Cull material can often be removed in connection with improvement cuttings to eliminate unprofitable trees and improve the composition and quality of the stand. A large proportion of the forests in North Carolina should receive this treatment, but markets are often a limiting factor. This is particularly true in the mountain hardwoods, where improvement cuttings are badly needed. In the piedmont and Coastal Plain, stands can be improved more easily because of the better commercial market for lowgrade hardwood for pulpwood or lumber and for farm use. This makes possible the removal of overmature, unsound, and poorly formed pine trees as well as the undesirable hardwoods.

The growing stock can be further improved by judicious thinning and pruning. Some of the old-field pine stands, in particular, are so densely stocked that growth of individual trees is retarded and most of them will respond quickly when thinned. The owner of the old-field pine stand shown in figure 43 has thinned his stand and thereby has obtained part of his fuel wood. Other timberland owners are making pulpwood thinnings. A great many more landowners in the piedmont and Coastal Plain can and should thin their timber stands to obtain the dual benefits of increased growth and an early crop of useful wood.
In some stands pruning can be a desirable improvement measure. Owners of large industrial forests will doubtless hesitate to make the necessary cash expenditure, but farmers who own old-field stands of pine can prune them in their spare time between crop seasons. Raising the quality of saw timber by pruning will mean more cash to the farm woodland owner, if he will insist on selling his sawlogs by grade.

\section{Improse Harvesting Methods}

Productivity of the forest is determined to a great extent by the methods used in harvesting the timber crop. On many commercial logging operations in the State a high proportion of all the merchantable timber is cut and the growing stock is left in a nonproductive condition for many years. Commercial operators should not be criticized for failing to utilize unmerchantable species, but the prevailing practice of cutting almost all of the pine and very little of the hardwood is transforming large areas of pine forest in to pine-hardwoods and in some places even to pure hardwoods. Furthermore, too little of the cutting follows any established silvicultural method and the composition of the new stand is left to chance. Some progress has been made in determining better methods of harvesting the various forest types, but the need is urgent for a much more intensive study of timber harvesting methods in North 
Carolina. Equally urgent is the need for disseminating the available knowledge to timberland owners.

\section{Protect the Forest}

It is futile to improve the forest growing stock unless adequate protection against fire, insects, and disease is reasonably certain. Great progress has been made in checking these destructive factors but there is still much to be done.

\section{Fire}

At present about one-third of the forest land in the State is without organized fire protection. Most of this land is located in the piedmont and in the tidewater counties lying north of Pamlico Sound. Up to now it has not been protected because funds were inadequate for State-wide protection and more efficient use could be made of available funds in the more heavily forested counties of the mountains and Coastal Plain. The unprotected counties furnish an important part of the lumber cut, besides a great quantity of other wood products, and thus deserve protection as rapidly as additional funds are made available.

While fire protection should be provided for all forest lands in the State, the increase in coverage should in no way reduce the intensity of effort on lands now being protected. Instead it is becoming more and more apparent that a greater degree of protection must be afforded them. In the past few years considerable forest land in the protected counties has been placed under some degree of management, but the disastrous spring fires of 1941 have caused many timberland owners to doubt whether present firecontrol methods are effective enough to justify planning for sustained-yield management. Forestry in North Carolina, particularly in the Coastal Plain, will receive a set-back unless better protection can be provided in the bad fire years.

\section{Disease}

Disease is a deterrent to high forest productivity because it often necessitates premature cutting of forest stands and also destroys a large volume of sound wood in individual trees. In North Carolina the chestnut blight killed an estimated 12 billion board feet of standing timber, providing a dramatic example of the damage caused by an uncontrolled disease. Most losses from disease are not so spectacular, but they constitute a steady drain upon the forest that can be largely avoided if suitable measures are taken. Decay in hardwoods following fire damage is one of the most serious causes of loss. The Division of Forest $\mathrm{Pa}$ thology, Bureau of Plant Industry, after an intensive study of fire damage, has demonstrated that about 45 percent of the money loss resulting from forest fires in the mountain hardwoods is due to decay in living, fire-scarred timber. For each acre burned over in 1939, the average estimated loss from decay was 62 cents, amounting to about $\$ 50,000$ in the mountain division alone. More intensive fire protection will reduce this loss.

Another disease having serious potentialities is the littleleaf disease, affecting shortleaf and to a smaller degree loblolly pine, which results in the gradual decline of individuals and small groups of trees 20 or more years of age and causes premature death. It was first reported in Alabama in 1934 and its present known distribution extends from Virginia to northeastern Mississippi. In North Carolina it is now present in a few piedmont counties, but has so far caused little change in silvicultural methods of commercial utilization except in a severely affected area around Shelby. The Division of Forest Pathology is making an intensive but so far inconclusive investigation of its cause and rate of spread. If the spread is rapid, adjustments in land use and forest industries may be forced in a large part of the piedmont.

Common throughout the forests of the State, although not so conspicuous, are top rot in hardwoods and red heart in pine. Top rot is caused by several kinds of fungi which gain entrance through broken stubs and wounds on the upper part of the trunk. Practical guides for recognizing its presence and the probable susceptibility of standing trees, established by the Division of Forest Pathology, enable the forest manager to cut poor risks at an early stage before decay is far advanced. Red heart is caused by the fungus Fomes pini which usually enters through dead branch stubs and destroys the heartwood, primarily of mature pines. Southern pines, except Virginia pine, seldom decay until more than 80 years old. Conks, or sporophores, and punk knots are the most reliable indications of decay. Losses from both red heart and top rot can be reduced through the early utilization of susceptible and infected trees and the adoption of as short a rotation as will produce timber of usable size.

\section{Insects}

Insects are particularly destructive because they injure and kill standing timber, damage sawlogs and bolts lying in the woods, and cause extensive losses of manufactured wood products. In effect, drain is materially increased because of their activity and the adequacy of the forest growing stock is substantially reduced. Probably the most destructive insect destroyer of timber in North Carolina is the tree-killing southern pine beetle (Dendroctonus frontalis). Ordinarily rather rare, during periods of drought or following fires the beetles may increase rapidly and cause 
damage of serious proportions. In Hertford County in 1938 about 4 million board feet of old-growth pine was killed in a single local infestation.

Unless promptly salvaged, such timber is subject to damage by the southern pine sawyer (Monochamus titillator), which also attacks other dead trees and unbarked pine logs left in the woods for more than 3 weeks in the summer. Lumber from infested timber is often worthless because of the large tunnels and holes made in the wood by the developing larvae. And even when timber is successfully made into finished products it is still subject to insect damage. Among others, the Lyctus powder-post beetles cause serious losses in the seasoned sapwood of lumber, handles, furniture, vehicle stock, woodwork, picker sticks, and similar products made from oak, ash, and hickory.

These are only a few of the many insects constantly destroying the timber grown in North Carolina, but losses could be held to a minimum if more trained forest entomologists were available to discover insect outbreaks and instigate control measures while the infestations were in their early stages.

\section{Improve Timber Utilization}

Full development and protection of the forest growing stock will not insure commensurate benefits unless utilization is of the same high standard. Furthermore, because of their interdependence, any single one of these goals is difficult to attain. The more important of the ways to improve timber utilization in North Carolina are: (1) Increase the use of certain little-used species and lower grades of hardwood, (2) develop more small wood-products plants, (3) develop integrated wood-using industries, (4) correct the malpractices of the portable sawmill, (5) convert a higher proportion of the low-grade pine into pulp, (6) use more of the best timber for veneer and plywood, (7) increase the use of chestnut, (8) develop and put into use $\log$ grades for pine and hardwood saw timber, and (9) improve marketing of forest products.

\section{Utilization of Hardwoods}

Under prevailing practice, a concentrated cut is depleting the best grades and species of hardwoods. Conversely, the hardwood volume in culls and less-used species is increasing. About 25 percent, 38 million cords, of the total volume in hardwood trees 5 inches $\mathrm{d}$. b. h. and over is cull and an additional large volume is in such species of limited merchantability as scarlet, post, water and willow oaks, elms, and hickories. Failure to use a greater proportion of this large volume of wood is an economic waste and is also poor forest management.
Greater utilization depends upon finding profitable ways to use this material. For instance, there is a chance to use a much larger volume of culls and tops for fuel wood in all parts of the State, and so reduce the volume of saw timber now cut for fuel. Most of the 6 million cords of cull black and water tupelo is suitable for some type of pulp. Some is now being used and consumption should be increased. The wood of cull chestnut oak trees may be useful as a source of tanning extract. A small amount is used commercially in Alabama and some Virginia plants have used it experimentally. Extract plants in North Carolina could well afford to experiment with it, as most of the chestnut will be gone in 10 to 15 years. Other little-used species can be employed for local building. In the mountains it is common practice for portable mills to saw out house patterns and other rough construction material from poorquality oaks and other hardwoods. The rural buildings constructed from this material are satisfactory and a comparable use of the low-quality hardwoods growing in the piedmont and Coastal Plain would help to reduce the overcut of pine and the surplus of poor-quality hardwoods. Wood-products manufacturers can also market a wider variety of species if they will develop and popularize certain species for limited uses as they have done in the case of soft maple for furniture. These are only a few of the possible ways to utilize the low-quality hardwoods. Many more should be developed. ${ }^{11}$

\section{Small Wood-Products Plants}

More small plants, manufacturing finished or semifinished wood products, are particularly desirable in the mountain region. They offer an opportunity for profitable use of low-grade hardwoods as well as the premium species. For lack of suitable markets small sawmill operators may sell walnut, black cherry, curly maple, and other high-value woods along with common lumber at low prices, with loss to the timber grower and themselves. Good saw timber is becoming scarce in the mountains and for the next several decades the rural people dependent upon the lumber industry will need additional opportunities for employment. No plant is too small to provide some benefit in a region where many people do not have $\$ 100$ cash per year. Small finished products provide more employment per unit of wood than do sawmills, and usually at a higher wage rate. Markets will influence the kind of products manufactured, but furniture, handles, sports equipment, toys, woodenware, venetian blinds, spools, gunstocks, toothpicks,

\footnotetext{
1t Of considerable assistance in this endeavor is Davis, E. M., MACHINING AND RELATED CHARACTERISTICS OF SOUTHERN HARDWOODS. U. S. Dept. Agr. Tech. Bul. 824, 42 pp., illus. 1942.
} 
buttons, dowels, shade and map rollers, boot and shoe findings, and novelties are possibilities. The recently reestablished pipe-block industry, which uses laurel and rhododendron burls for raw material and has an annual pay roll of about $\$ 150,000$, exemplifies the type of development that should be expanded, although this particular industry may be halted when trade is resumed with the Mediterranean countries.

\section{Integrated Industries}

In all three of the major forest regions of the State there is room for more centralized plants manufacturing a variety of wood products. They offer economies in timber procurement and manufacturing costs, better utilization of grades and species, and a chance for great refinement of the product. They are particularly desirable in hardwood territory where forest management is difficult because of a lack of market for some species. More plants should be equipped to manufacture or fabricate core stock, flooring, dimension stock, cabinets, window and door frames, sash, blinds, screens, mantels, and doors, in order to keep up the attendant employment, pay rolls, and income for local benefit.

\section{Portable Sawmills}

Over two-thirds of the annual production of lumber in North Carolina is cut by small portable mills. In a normal year over 2,500 mills operate in about 10,000 different tracts of timber, few of them owned in fee simple by the operators. Commonly these small mills cut the young timber before it is financially mature and frequently leave the cut-over stand in poor condition for further growth. Furthermore, much of the lumber produced is so poorly manufactured and carelessly handled that waste and degrade are high. Granting due credit to those operators who are cutting conservatively, the influence of the small mills in general constitutes a serious obstacle to efficient forest production and utilization.

On the other hand, small portable sawmills have certain advantages which should not be overlooked. Many are custom mills, producing low-cost building material from home-grown timber. These small mills move from farm to farm, sawing as little as 10 to $15 \mathrm{M}$ feet at a set-up. Because of this flexibility they can serve, if properly controlled, as useful tools of forest management. Both custom and commercial portables can utilize scattered mature trees or small areas of mature timber. Stands containing a high proportion of low-grade material are often operable only by these mills. In the mountain forests, particularly, these small mills can be a constructive force in improving the growing stock. Moreover, they provide considerable employment, distributed throughout every county of the State.

So far, no adequate plan for improving small-sawmill practices has been developed. Good forest practice and operating deficits are incompatible, and the history of many mills is one of rapidly changing ownership because of unprofitable operation. To be satisfactory such a plan must provide ways to check destruction of the forest resource and at the same time promote economic security for mill operators and landowners. Public control of cutting practices alone would not do this. Both the manufacturing and business phases of small-mill operation must be improved, so that operators can establish themselves on a sound financial basis.

\section{Low-Grade Pine for Pulp}

With suitable safeguards the piedmont region would benefit through the establishment of one or more pulp and paper mills. A large part of the second-growth pine is of old-field origin and of rather poor quality. Many of the stands need thinning, and more improvement cuttings should be made to raise the quality of the growing stock. With a pulpwood market it would be possible to manage more forest land for the integrated production of pulpwood, saw timber, poles, veneer bolts, and other forest products, thus increasing the revenue from the land and developing the forest growing stock to a higher degree of productivity. Many of the progressive pulp and paper companies recently established in the South are practicing integrated management on their own lands and some, even at their own expense, mark timber for integrated utilization when they buy pulpwood from other landowners. Similar practices put into effect in the piedmont would be a great improvement over those now followed by small sawmills.

\section{High-Quality Timber for Special Products}

With the available markets in North Carolina there is a chance to produce more high-quality timber. Veneer bolts, first-quality sawlogs, long poles and piles, are a few of the possible products. The veneer plants of the State use over 100 million board feet of veneer bolts each year and there is a market for a few million feet annually in Virginia. In normal times high-grade bolts bring $\$ 25$ to $\$ 35$ per thousand board feet, log scale, delivered at the mill, and stumpage sells for $\$ 8$ to $\$ 10$ per thousand.

Although actual prices vary slightly between mills, the relationship is fairly constant, and sample quotations from lumber company price lists typify the differences between high-grade and low-grade logs. These indicate that No 1 
pine logs delivered at the mill were worth $\$ 16$ per thousand board feet, Doyle log scale, in July 1941, whereas No. 2 logs were worth $\$ 12$. High-quality white and red oak logs brought $\$ 25$, but No. 2 logs brought only $\$ 16$. In both cases, prices for small No. 2 logs would be even less.

Profits can also be increased by managing pine stands to yield a crop of long poles and piles harvested before the saw timber. On a property in northeastern North Carolina in the summer of 1941, trees that would cut out 65-foot poles sold for $\$ 6.50$ each on the stump and those suitable for 85 -foot poles sold for $\$ 11$ each. A comparable stumpage price for saw timber was about $\$ 4$ and $\$ 6$ per tree.

\section{Increased Use of Chestnut}

Efficient utilization of the 6.5 million cords of blightkilled chestnut estimated in 1938 to be commercially available is primarily a matter of using as much as possible before it decays, burns, and otherwise deteriorates. At the rate of about 300,000 cords per year - the average industrial use of saw timber and extract wood between 1937 and 1940 - the available supply would last about 20 years if there were no natural losses. Deterioration is rapid, however, and losses will increase with each succeeding year.

Anticipation of these losses by an increase in consumption will enable the people and industries to realize the values in this large volume of raw material, but the feasibility of such an effort depends upon active markets for chestnut extract, liner board, and lumber, and upon adequate supplies of woods labor and logging equipment. Export outlets for extract have been curtailed because of the war, but domestic needs have increased as our industries and armed forces expanded; the greater demand for containers and packing material to ship the manufactured goods has directly improved the market for chestnut liner board. At present (1943) extract plants are using all the wood obtainable. To salvage the wood before it deteriorates, it may be necessary to continue production at a high level after the war or to stock pile wood ahead of immediate requirements.

\section{Standardized Log Grades}

At present most of the standing timber is sold by the lump sum, i.e., so much for the tract; logs are usually sold at the mill by the thousand board feet log run. A few operators buy logs according to grade, but these grades differ at almost every mill. Accordingly, high-quality timber is usually sold along with the poor, often at the same price and scarcely ever at a price based upon grade yields of lumber. Wood-products industries, as well as the owner, are penalized by this custom, because they are un- able to specify logs most suitable for their particular type of operation. Until standard log grades for both pine and hardwoods are developed and put into use, the timber owner is handicapped in selling his product. There is no great incentive for him to grow high-quality saw timber for sale, since he cannot be confident that it will bring an appropriate price. Standard log grades would eliminate these faults in present marketing methods and would benefit buyer and seller alike. They should be developed as rapidly as possible for use in North Carolina and all other Southern States.

\section{Marketing of Forest Products}

A large part of the wood used by the forest industries in North Carolina is purchased delivered at the mill yard or as standing timber. As previously mentioned, few of the logs are bought by grade, and stumpage is usually purchased on a lump-sum basis. Farmers and other owners of small timber tracts are often unable to obtain full value for their wood under these conditions, because they do not know the best methods of harvesting and measuring their timber and as individuals they have little bargaining power. As a result, many timberland owners do not consider intensive forest management worth while.

To stimulate better forestry, timber growers should receive more practical advice and assistance on timber estimating, cutting methods, log grading, timber values, and market opportunities. The most effective way to accomplish these objectives is by personal instruction and demonstration. Several publicly employed foresters are already engaged in this work but there is need for greatly expanded effort. A forester in each of the heavily timbered counties is desirable.

Cooperative marketing associations offer another way for farmers and small owners to improve marketing conditions. Protection is thereby afforded the small producer, and better prices are usually obtainable. 'The buyer can afford to pay more because he is buying assembled material from one source; he can check specifications more easily; and he is reasonably certain of the supply. Cooperatives have many pitfalls, however, and to be successful they should be operated by, or receive the advice of, a technical forester with a sound knowledge of business practices.

\section{Expand Public Ownership}

Wherever forest land can be managed successfully by private owners who are willing and able to keep the land continuously productive, there is no need for a great increase in public ownership. But where private owners 
are unable or unwilling to maintain productivity, public ownership is desirable. Public ownership of forest lands in North Carolina should aim to secure the following: (1) Forest management on land that is submarginal for private ownership; (2) protection of the watersheds of certain streams; (3) blocking up of existing public forests and purchase units for more efficient administration; (4) provision of additional recreational areas; and (5) demonstration of good forest management including the production of high-quality timber. Communities and counties should acquire some of the land, but the bulk of it should be in State or Federal ownership.

\section{Intensify Research}

Before the people of North Carolina can manage and utilize their forest and and resources to best advantage, they must have more definite information concerning good forest practices. Some of the needed information is available, lacking only application. A much larger part is still to be obtained by careful experimentation and investigation. Few individual landowners are able to do more than practice trial and error methods which are usually expensive and time-consuming. The best way to meet the need is by organized research under the direction of skilled technicians. These can be either privately or publicly employed, but in North Carolina where small landowners and small wood-products industries predominate, much public research is necessary. Responsibility for this research rests partly with the State, partly with the forest schools, but predominantly with the Forest Service, since it maintains a regional forest experiment station within the State to study forest problems of this and neighboring States. The research activities of all these agencies should be closely coordinated.

Forest research has been under way at the Appalachian Forest Experiment Station at Ashville, N. C., since 1921. During this time considerable progress has been made; but constantly changing forest and economic conditions create problems that cannot be solved by a stereotyped research program of limited duration, and therefore there are still many investigations to be completed and others to be started. To be effective, research must be able to attack new problems as they arise without abandoning established long-time investigations basic to the practice of forestry. In North Carolina greater emphasis should be placed on the following phases of forest research:

1. Determination of the most satisfactory silvicultural management for pine in the Coastal Plain and piedmont.

2. Costs and returns of sustained-yield management, particularly in the mountain hardwoods.
3. Comparative advantages of growing pulpwood, sawlogs, veneer bolts, or other forest products with respect to net income, cutting cycles, employment, and industrial development.

4. Methods of classifying soils as to their potential forest productivity in order to obtain a sound basis for making land use classifications.

5. Forest-products research to develop new and expand old markets to facilitate utilization of little-used species and low-grade material.

6. The small sawmill industry, with special emphasis upon cutting practices, logging and milling, marketing of product, and finances.

7. Improvement in fire protection and control technique, especially in the Coastal Plain; also investigations to determine economically justifiable expenditures for fire control, by forest types, and the equitable apportionment of such costs among public and private interests.

8. Forest watershed management and its effect upon erosion, water supply, stream flow, and flood control.

9. Intensification of the Forest Survey to provide volume, growth, and drain data by counties and industrial territories.

10. Planting of denuded areas and abandoned fields in the western Coastal Plain and piedmont with emphasis on methods, costs, species, sites, and returns.

11. Beef cattle production in the Coastal Plain forests, its possibilities and correlation with timber production.

12. Development of standard log grades for pine and hardwoods.

13. Pond pine silviculture to obtain more effective use of pocosins and "open land."

14. Forest land use planning to bring about a proper balance among forestry, farming, watersheds, recreational areas, range use, and wildlife developments.

15. Forest economics investigations to determine the relative net returns to the owner and the relative employment made available to the public from maintaining growing stocks of $1,3,5,8$, or $10 \mathrm{M}$ board feet per acre in each important softwood and hardwood type.

Intensive research along these suggested lines will provide the basis for a great improvement in timber management and utilization. Forest research requires time, however, and measures to increase the utility of the forest resource should not be delayed. With existing knowledge there are many opportunities to improve forest practices, growing stock, protection, and utilization for greater social and economic good. These opportunities can be realized through an organized action program participated in by individuals, local governing bodies, and public agencies. 


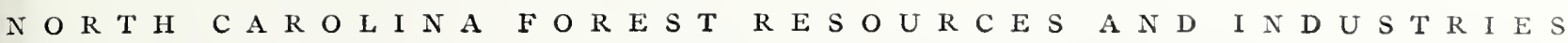

\section{Permanent Forests for North Carolina}

$-2, y$

7 MAINTAIN and build up the forest values now on hand in North Carolina and to take advantage of opportunities for increasing the contribution of the forest to the social and economic structure of the State and Nation, it is necessary to revise present methods of handling this important resource. Responsibility rests jointly upon the Federal Government, local and State governing bodies as representatives of the public; and on the private landowners and forest industries. All have an interest in, and all will benefit from, ample and widely used forests. A comprehensive, intergrated program of action in which all these agencies participate can attain and support a high level of forest productivity.

\section{Public Regulation}

After more than 200 years of heavy cutting, 3 acres out of 4 in the forests of North Carolina are not satisfactorily stocked with trees. Current growth is only about half of what it reasonably could be. Public regulation of cutting practices is deemed necessary to stop further destruction and deterioration of growing stock and to help sustain forest industries and dependent communities.

Regulation should be an advantage to private forest owners and operators. For the timberland owner practicing forestry it will tend to maintain markets for stumpage by encouraging stable local forest industries. For the operator it will tend to assure a permanent supply of good-quality sawlogs and other forest products. It should protect both from some of the bad effects of irresponsible one-cut owners and operators.

Regulation of forest practices will serve to safeguard the investment of the State and Federal Governments in fire protection and other cooperative activities. It should forestall the social and economic maladjustments generally associated with forest liquidation and frequently involving higher taxes, unemployment, and lowered standards of living.

Public regulation of forest practices should require reasonable measures for the prevention and control of fire, precautions against injurious insects and disease, and methods of cutting which will not impair forest productivity. To this end not only will it be essential to provide for adequate restocking with trees of desirable species and to prevent avoidable damage to uncut trees and young growth during logging, but also it will generally be necessary to restrict clear cutting, to protect young stands from premature or wasteful cutting by limiting cutting in such stands to salvage, thinning, or other stand-improvement practices, and where feasible to reserve a sufficient growing stock of thrifty trees of desirable species to keep the land reasonably productive.

The productivity of North Carolina's forest is a matter of national concern. Other States look to her for part of their lumber supply, and her economic welfare is an inseparable part of national prosperity. Accordingly, regulation of forest practices in North Carolina should be developed as an integral part of a Nation-wide forest policy. The Forest Service belives that the public interest requires, as a minimum, a large measure of Federal participation and strong Federal leadership in such forest regulation.

\section{Private Action}

Private landowners and the forest industries have a direct interest and responsibility in the prevention and control of forest fires and in the application of improved forest-management and timber-utilization practices on their own land. A large part of these improved practices should result from their own initiative, and the remainder from cooperation in public programs.

\section{County Action}

Because every county in the State is more than onethird forested and a majority are more than a half, the policy-forming officials in each county should adopt a constructive attitude toward the forest resources and related industries. In too many cases the timberland is regarded merely as a source of taxes; the possibility of greater development to insure more local employment, to stabilize rural 
communities, and to provide a broader tax base has not been considered a county responsibility. Because this responsibility does exist, each county should support the following plan of action:

1. To cooperate financially with the State and Federal Government in fire protection on private forest land. In the fiscal year 1942 county and private contributions for fire control totaled about $\$ 78,000$, but for various reasons 11 counties were not cooperating. On the basis of estimates by the Forest Survey about 17 million acres should have State-administered forest-fire control. The State's estimate of the cost of adequate protection is about 4.6 cents per acre per year, or approximately $\$ 785,000$ for this State-wide area. Of this total, some $\$ 200,000$ could justly come from county and private funds.

2. In those portions of the State where forest land predominates or is the major source of income, to cooperate with the State and Federal agencies in employing local foresters to assist farmers and small private owners and operators to apply sound forest practices and to find markets for their forest products. Fifteen counties have over 75 percent of their land in forest. Local appraisal of the situation is necessary to determine the required number of foresters.

3. To encourage better management of forest land through equitable and up-to-date methods of taxation. Faulty assessment is the major defect in the present method of taxing forest property; but it is also true that the nature and administration of the property tax is not conducive to progressive forest management. County governments should improve assessment practices and the administration of the present tax law and should give their support to a sound differential timber-tax bill, such as that already presented to the general assembly.

4.- Local planning committees to give full consideration to the conservation and development of the forest resources of the counties, coordinating them with the other resources in a unified program of land use.

\section{State Action}

The prosperity of the people and industries within the State depends, to a great extent, upon the available resources and the prudence with which they are utilized. The State government, representing the people, has a direct responsibility to assist in the maintenance of productive resources and in the development of principles and controls for their utilization. With respect to the forest resources, the State has the responsibility for the following lines of action:

1. To provide adequate fire protection for all State and private forest land with funds furnished by the State and
Federal Governments, counties, and private landowners. The State's contribution in the fiscal year 1942 was $\$ 58,750$, but for adequate protection $\$ 300,000$ annually would be needed. 'This sum, added to Federal and county cooperative funds, would provide intensive protection on the 11.7 million acres under agreement in 1941 and would extend coverage to the 5.5 million acres now without protection. The need for greater effort on fire control is apparent in the fire record of the first half of 1941. During this unusually dry period fires burned over nearly 6 percent of the forest land protected by the State as compared to about 2 percent in 1940, causing damage amounting to nearly $\$ 1,000,000$.

2. To provide assistance to timberland owners in reducing the losses caused by forest diseases and insects. A trained forest pathologist and forest entomologist should be attached to the State forester's staff, to work in close cooperation with the State entomologist and the Division of Forest Pathology and Forest Insect Investigations at the Appalachian Forest Experiment Station. Under a revised Federal act to provide for cooperative protection against forest diseases and insects as well as fire control on private and State-owned land, at least $\$ 10,000$ of State funds would be needed annually to finance both activities.

3. To provide tree seedlings or seed to all landowners who wish to reforest idleland. The Forest Survey estimates there are about 545,000 acres in need of complete planting and about 1.4 million acres of sparsely stocked forest land that should be interplanted for maximum production In the year ending in June 1940, the State Division of Forestry distributed about 2.5 million trees to its cooperators, enough to plant approximately 2,000 acres. Obviously this rate of planting is too slow. Under the present cooper ative agreement, nursery stock is produced in State-operated nurseries with Federal and State funds. Federal contributions, exclusive of Civilian Conservation Corps labor, have amounted to less than $\$ 2,000$ per year, however, and the total Federal and State expenditure, including money obtained from the sale of seedlings, is only about $\$ 15,000$ per year. To make significant progress in the planting program it is estimated that a total expenditure of at least $\$ 50,000$ annually would be needed. Presumably the State and Federal Governments would share the costs not covered by the sale of seedlings.

4. To provide more assistance to farmers in the management of their woodlands. This can be accomplished through the employment of more foresters to advise individual farmers concerning good management practices and to assist them in obtaining a satisfactory market for their forest products. 'The forestry personnel could be made available through cooperative arrangements between 
Federal, State, and local governments, or possibly farmer organizations. Costs could be shared by the cooperating agencies.

5. To provide more assistance to industrial and other nonfarm owners of timberland. Work of this character was started in November 1938, when the State and Federal forest services agreed to share the cost of a technical forester whose time was to be devoted to forest management work on private lands. In the first 2 years this forester made recommendations to 172 cooperators for improved management practices on 849,400 acres of forest land. The demand for expansion of this service is increasing, and with nearly 6 million acres of industrial and other private nonfarm forest land not yet under organized management, there is need for at least two more technical foresters.

6. To provide State forests for demonstration, timber production, watershed protection, and recreation. Probably the most important function of these forests would be to provide demonstrations, under natural conditions, of the methods and results of various types of forest management. For this reason, they should be distributed throughout the several forest regions of the State in order to be available to a large proportion of the forest-land owners. In case the State cannot provide the necessary funds for the purchase of State forests it may be able to obtain Federal assistance through the provisions of the Fulmer Act, if funds are provided by Congress, and through Title III of the Bankhead-Jones Farm Tenant Act.

7. To provide a satisfactory legislative framework for the taxation of forest land. As mentioned previously, the present system has an unfavorable influence upon the adoption of forest management practices. Taxation specialists of the United States Forest Service have already studied the problem in North Carolina and have made recommendations to the Classification Amendment Commission. These recommendations have been incorporated in a bill submitted to the general assembly.

8. To collaborate with the Federal Government in the regulation of forest practices on private lands.

\section{Federal Action}

Since abundant forests, wisely used, contribute to a strong Nation with a secure and prosperous people, the Federal Government has a direct interest in the use and management of the forests in each State. This public interest has been recognized through financial assistance to the States for cooperative fire protection, planting, and similar activities designed to increase the forest's contribution to the whole social and economic life of the Nation. The progress made should not be minimized, but forest conditions in North Carolina and the rest of the Nation indicate clearly that the Federal and State Governments, along with the private owners and local governments, have failed to meet their obligations in respect to the forest resource. To help remedy the situation, the Forest Service submitted general recommendations to the special committee of Congress appointed in 1938 to study the forest situation nationally. These recommendations included lines of activity in which the Federal Government has major responsibility and were sufficiently inclusive to cover the following, which are deemed necessary to improve the forest situation in North Carolina:

1. Public regulation of forestry practices on privately owned forest land.

2. Increased Federal contributions to the State for fire control. The Federal share to meet the full State contribution as estimated above would be approximately $\$ 300$,000 , instead of the $\$ 71,000$ provided in the fiscal year 1942 .

3. Financial cooperation with the State to support a forest pathologist and a forest entomologist. This would cost about $\$ 10,000$ of Federal funds annually.

4. Federal participation in the production of tree seedlings for industrial and other nonfarm forest-land owners. The present Clarke-McNary Act limits seedling distribution to farmers. The proposed program would involve an increase in the present annual contribution from about $\$ 2,000$ to at least $\$ 10,000$.

5. Expansion of the Federal-State cooperative farmforestry program to provide additional forestry personnel for assisting farmers in the management of their farm woodlands and in the marketing of their wood products.

6. Greater cooperation with the State Division of Forestry in extension work with industrial and nonfarm forest owners, as recommended as a part of State action. The Federal Government's share of the cost would be about $\$ 10,000$ annually.

7. Provision for credit facilities for industrial and other nonfarm forest owners which at present do not have access to adequate credit. Credit is needed to make forest investments more liquid without liquidation of the growing stocks to facilitate organization of sustained-yield units, to prevent sacrifice of immature timber, to meet carrying costs, to make necessary improvements, to refund oppressive debts, and to assist small owners in processing and marketing forest products. Basically, forest credits should be restricted to forest properties capable of yielding regular income and managed in accordance with sound principles of good forest practice. Forest credit for commercial timberlands under forest management is new and, because of fire, insect, and disease hazards, it has a large element of risk if too localized. For these reasons it should be adminis- 
tered by a Nation-wide organization, such as the Farm. Credit Administration.

8. Assistance to farmers and other small forest owners in the formation and operation of forest cooperatives for the marketing and, in some cases, manufacture of forest products. Aid should presumably consist of publicly employed personnel to give advice on management of timberlands, manufacturing, marketing, and on credit facilities for establishing small manufacturing plants or the purchase of cooperative equipment. These services can be provided through measures already recommended. More local foresters provided as already explained, would supply the needed personnel, and credit would be available under the provisions of the proposed forest credit item. A limited amount of credit for developing forest cooperatives is also now available to farmers through the Farm Security Administration. Forest cooperatives would be particularly beneficial in the piedmont, where a high proportion of the forest is in farm woodlands.

9. Expansion of forest research in order to tackle new investigations and intensify work on problems now treated inadequately. Most of this expansion can be undertaken efficiently at the Appalachian Forest Experiment Station. The additional research work on projects of direct benefit to this State and to other States in the station's territory would cost at least $\$ 100,000$ annually.

10. Increased support of local communities and industries by the national forests. There is opportunity, particularly in the mountains, for the development of cooperative agreements hetween the Forest Service and several of the larger lumber companies, whereby the companies would obtain their annual requirement of saw timber from the national forests without competitive bidding, at a fair price fixed periodically by the Forest Service. Additional legislation to authorize this would be required. This would help to establish permanent industries and would be contingent upon good forest practice on lands owned by the lumber companies.

11. Development of a better method of reimbursing counties in lieu of taxes where national forests occupy a large part of the county area. At present 25 percent of the receipts from national-forest timber sales, special-use permits, and other miscellaneous sources, is contributed to the support of local schools and roads. This money is first paid to the State, and the sum from each national forest is then distributed to the counties in which located in proportion to the national forest area they contain In the fiscal year 1942, the national forests returned $\$ 27,469$ to the counties, about 3 cents for each acre of national forest. Taxes on similar land in private ownership were in general substantially higher in these counties.

The disparity between Federal contributions and local tax losses will decrease as the national forests are built up and larger volumes of timber become available for sale. In the meantime, however, the contributions on this 25 -percent basis may be found inadequate in some localities. One suggestion for remedying this temporary difficulty which deserves serious consideration is that the Federal Government make a minimum annual contribution equal to a stated percentage of the purchase price of national-forest lands. It has been suggested that this percentage contribution be three-fourths of 1 percent, which is only a little less than the average tax levy on farm real estate in North Carolina, as reported by the Bureau of Agricultural Economics, which was 0.87 of 1 percent of full value in 1941. A reduction of this order would be offset in many counties by the decreased need for services of local government on account of Federal construction and maintenance of certain roads and other features of national-forest administration. Such a minimum would be superseded by the 25-percent basis for contributions to local governments as soon as receipts were sufficiently large. Based on acquisition to June 30, 1941, such a minimum Federal contribution in Macon county, which has the largest area of national forest, would be $\$ 6,927$, or 4.8 cents per acre. On the same basis, the minimum for the entire State would be $\$ 36,361$, or 3.9 cents per acre, which would equal about one-third of the national-forest receipts in the fiscal year ended June 30, 1942.

12. Acquisition, as feasible, of more land for national forests. Many tracts of land within the forest boundaries of the Pisgah and Nantahala National Forests should be purchased to reduce administrative expense, fire hazard, and trespass. Also a rather large area on the east side of the Blue Ridge Mountains, lying chiefly in Wilkes County, could be added to the Pisgah National Forest to afford more protection to the watershed of the Yadkin River, a very important source of hydroelectric energy. The Uwharrie Ranger District in the piedmont should also be expanded to include more land now subject to serious erosion. 


\section{Appendix}

$\therefore$

\section{Survey Methods}

\section{Field Inventory}

T

THE field inventory of the forest resources of North Carolina was started in the early part of 1937 and completed in the summer of 1938. To facilitate analysis and use of the data, the State was divided into four survey units, the southeastern Coastal Plain, the northeastern Coastal Plain (these two combined in this report), the piedmont and the mountains.

In the field survey six three-man crews gridironed the State with compass lines spaced 10 miles apart (fig. 44). At intervals of $1 / 8$ mile along these lines, $1 / 4$-acre sample plots were established. Records obtained on 37,730 plots form the basis for computing the areas devoted to the various kinds of land use. Of these 22,140 were forest plots and here detailed measurements and observations were made concerning the number, size, and species of trees, the forest type and stand condition, degree of fire damage, density and distribution of reproduction, growth, and site quality. Data for the construction of volume tables were collected through supplementary sampling by J. IV. Girard of the Forest Service, who also determined timber-cull percentages.

The Great Smoky Mountains National Park was omitted from the survey because it is withdrawn from commercial use. Its 227,000 acres bear an estimated 794 million board feet of timber by the Scribner log rule. It is an area of high, rugged topography and contains most of the red spruce and Fraser fir still remaining in North Carolina.

\section{Increment}

Measurements for growth calculations were obtained from increment borings made in a mechanically selected sample of all trees over 3 inches in diameter. In general, computational procedure consisted of determining the

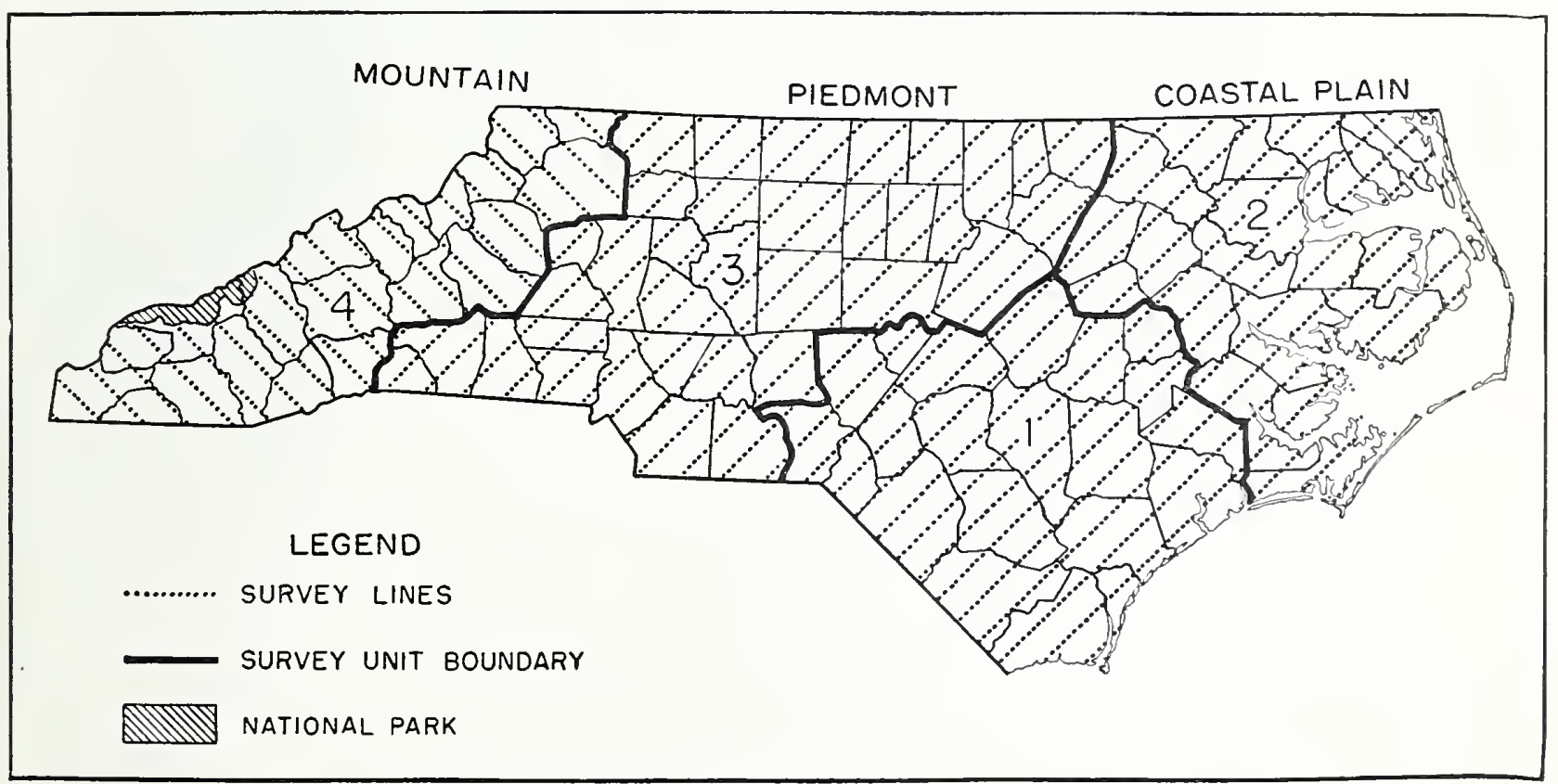

FIGURE 44.-Physiographic divisions, surcey units, and approximate location of survey lines in North Garolina. 
volume of small trees that grew to merchantable size during the period and of increasing the sample-tree diameters by the measured diameter growth of the past decade. The difference between the present and projected volume of the sample trees was then expressed as a percentage increase and applied directly to the inventory volume.

\section{Drain}

Data on forest industries and estimates of commodity drain for the year 1937 were based upon an intensive field canvass of the primary forest-products plants and domestic wood consumers Since 1938 the Forest Service has cooperated with the Bureau of the Census to obtain lumberproduction information and other wood-products statistics. This cooperation consisted of editing Census forms and of making a field check of new and nonreporting operators.

\section{Computations}

Compilation of the inventory and growth data was accomplished through the use of punch cards. The machine tabulations obtained from the punch cards could be used directly in the preparation of final tables. The flexibility, uniformity, and economy of this method made possible the rapid, precise compilation of a large volume of data at reasonable cost.

\section{Definition of Terms Used}

\section{Land-Use Classes}

Productive forest land.-Forest land having qualities essential for the growth of merchantable saw-timber stands.

Nonproductive forest land.-Forest land lacking the qualities essential for the grow th of merchantable saw timber.

Cropland, old and new.-Land used for production of farm or orchard crops or evidently so used during the past 5 years.

Pasture.-Cleared or open land under fence used primarily for grazing.

Abandoned cropland.-Land once cultivated but showing distinct evidence of having been abandoned for agricultural crop production.

Other nonforest.-Land included within the corporate limits and suburban or industrial sections of cities and communities; power, rail, and highway rights-of-way: marsh, and nonmeandered waterways.

\section{Species Groups}

Softwoods.-Loblolly, shortleaf, pond, longleaf, Virginia, Table Mountain, pitch, and eastern white pines, eastern hemlock, red spruce, Fraser fir, eastern redcedar, Atlantic white-cedar (Chamaecyparis thyoides), and baldcypress.

Hardwoods.-Sweetgum, hlack, swamp, and water tupelos, rellow poplar, oaks, American chestnut, hickory (Carya spp.), ash, elm, maple, flowering dogwood, and associated minor species.

\section{Species Mentioned}

\section{SOFTWOODS}

Lumber or trade name

Cedar, red.............. Eastern red cedar

Cedar, white.............Atlantic white-cedar ("southern white cedar")...

SBldcypress ("southern cypress").

Cypress

Fir, eastern

Pondcypress.

Fraser fir ("southern balsam fir").

Eastern hemlock.....

Hemlock .............. Carolina hemlock. .

Loblolly pine

Longleaf pine

Pitch pine

Pine, southern yellow........ Pond pine.

Shortleaf pine

Table Mountain pine

Virginia pine

Pine, white

Eastern white pine.

Red spruce.....

Recognized common name

Spruce, eastern

\section{HARDWOODS}

Ash, mountain . .

American mountain-ash

White ash

Ash, white

Carolina ash........

Basswood

\section{Botanical name}

Tuniperus virginiana

Chamaecyparis thyoides

Taxodium distichum

T. ascendens

..... Abies fraseri

.... Tsuga canadensis

T. caroliniana

Pinus taeda

P. palustris

P. rigida

P. rigida serotina

P. echinata

$P$. pungens

P. virginiana

P. strobus

Picea rubra
Sorbus americana

Fraxinus americana

F. caroliniana

Tilia glabra 
Lumber or trade name

Beech

Birch

Buckeye.

Butternut.

Cherry

Chestnut.

Cottonwood

Dogwood

Elm, soft

Gum, black

Gum, red.

Hackberry

Hickory .

Holly

Honeylocust

Laurel.

Locust

Magnolia

Maple, hard

Maple, soft

Mulberry

Oak, red

Oak, white.

Persimmon

Poplar, yellow .

Redbud.

Rhododendron.

Silverbell.
Recognized common name

American beech................

$\left\{\begin{array}{l}\text { Sweet birch } \\ \text { Yellow birch } \\ \text { River birch }\end{array}\right.$

River birch.

Ohio buckey

Black cherry

American chestnut

Swamp cottonwood

Eastern cottonwood

Flowering dogwood

American elm

Winged elm.

Black tupelo ("blackgum")

Sweetgum.

Hackberry

Hickory .

American holly

Honeylocust.

Mountain-laurel

Black locust . . .

Cucumbertree.

Fraser magnolia

Southern magnolia.

Southern sweetbay

Sugar maple.

Red maple.

Silver maple

Red mulberry

Black oak.

Cherrybark oak

Eastern red oak

Northern red oak

Scarlet oak.

Southern red oak

Water oak.

Willow oak

Chestnut oak

Chinquapin oak

Live oak

Overcup oak

Post oak.

Swamp chestnut oak

White oak.

Common persimmon.

Yellowpoplar.

Eastern redbud

Rosebay rhododendron

Carolina silverbell
Botanical name

Fagus grandifolia

Betula lenta

B. lutea

B. nigra

Aesculus glabra

Fuglans cinerea

Prunus serotina

Castanea dentata

Populus heterophylla

$P$. deltoides

Cornus florida

Ulmus americana

U. alata

Nyssa syluatica

Liquidambar styracifua

Celtic occidentalis

Carya spp.

Ilex opaca

Gleditsia triacanthos

Kalmia latifolia

Robinia pseudoacacia

Magnolia acuminata

M. fraseri

M. grandiflora

M. virginiana australis

Acer saccharum

A. rubrum

A. saccharinum

Morus rubra

Quercus velutina

2. rubra leucophylla

2. borealis maxima

2. borealis

2. coccinea

2. rubra

2. nigra

2. phellos

2. montana

2. muhlenbergii

2. virginiana

2. lyrata

2. stellata

2. prinus

2. alba

Diospyros virginiana

Liriodendron tulipifera

Cercis canadensis

Rhododendron maximum

Halesia carolina 


\section{HARDWOODS-continued}

Lumber or trade name

Srcamore..............

Tupelo.

Malnut

Millow

\section{Forest Types}

Loblolly pine, pond pine, longleaf pine, Tirginia pine.Stands in which pines make up 25 percent or more of the dominant and codominant stems with loblolly, pond, longleaf, or Virginia pine, respectively, predominating.

Shortleaf pine.-Stands in which pines make up 25 percent or more of the dominant and codominant stems with shortleaf pine predominating. Includes Table Mountain and pitch pine in the mountains.

I7hite pine.-Stands in which pines make up 25 percent or more of the dominant and codominant stems with white pines predominating Hemlock, red spruce, and Fraser fir are included although they form distinct types on limited areas.

Upland hardwoods. - Stands in which mixed oaks, hickories, chestnut, and other hardwoods make up 75 percent or more of the dominant and codominant stems.

Cose hardwoods. - Stands in which yellowpoplar, cucumbertree, red maple, white ash, black birch, buckeye, and basswood make up 75 percent or more of the dominant and codominant stems. I.imited to the mountain region.

Bottom-land hardwoods.- Stands in which sweetgum, tupelo, cypress, oaks, and other bottom-land and swamp species make up 75 percent or more of the dominant and codominant stems.

\section{Diameter Clossification}

D. b. h. (diameter at breast height).-Diameter, outside of bark, measured at 4.5 feet above average ground level.

Diameter class. - All trees were recorded in 2-inch diameter classes, including diameters 1 inch below and 0.9 above the stated midpoint: e. g., trees 7 to 8.9 inches are placed in the 8 -inch class.

\section{Tree Classes}

Sound sawlog-size tree.-A softwood tree at least 9 inches d. b. h., or a hardwood tree at least 13 inches $d$. b. h. with not less than one sound hutt $\log 12$ feet long, or with 50 percent of the gross volume of the tree sound saw timber.

Sound under-sawlog-size tree.-A tree over 1 inch d. b. h. and less than sawlog size with a reasonably straight, sound stem.

Cull tree.-A tree that fails to qualify as a sound sawlog-or undersawlog-size tree because of form, limbiness, rot, or other defect.

Pole tree.- A pine tree that will produce a pole conforming to specifications of the American Standards Association.

\section{Forest Conditions}

Old-growth uncut.- Stands composed of trees having the characteristics of the original mature timber of the region, containing at least $1 \mathrm{M}$ board feet per acre of merchantable species in hardwood types and 600 board feet per acre in pine types, with less than 10 percent of the original volume cut.

Old-growth partly cut.-Old-growth stands from which 10 percent or more of the volume has been cut, leaving a minimum of $1 \mathrm{M}$ board feet per acre in the hardwood types, or 600 board feet per acre in the pine types.

Second-growth sawlog-size uncut.-Stands of second growth having at least 600 board feet per acre in trees of sawlog size, and with less than 10 percent of the sawlog-size trees removed.

Second-growth sawlog-size partly cut.- Stands of second growth from which 10 percent or more of the sawlog-size trees have been removed but with the remaining stand containing 600 or more board feet per acre.

Second-growth under-sawlog size.-Young second-growth stands with less than 600 board feet per acre in trees of sawlog size and with the remainder of the trees below sawlog size, bu t averaging over 1 inch $d . b . h$.

Reproduction.-Stands too young to classify as second growth, having at least 80 well-distributed seedlings per acre.

Clear-iut.-Cut-over areas having insufficient young grow th to qualify either as second growth or reproduction.

All-aged.-Stands composed of trees of different ages or of many small even-aged groups of trees.

\section{Volume Estimates}

Board-foot colume.--Includes only the saw-timber portion of sawlogsize trees. Top diameters vary with the limits of usable material. Deductions are made for woods cull and for loss in sawing at the mill.

Cordwood colume.-This volume (including bark) embraces all of the following:

1. The sawlog portion of sawlog-size trees.

2. The upper stems of sawlog-size softwoods and the upper stems and limbs of sawlog-size hardwoods. The minimum diameter limit is 4 inches outside bark.

3. The full stem of sound under-sawlog-size trees at least 5 inches d. b. h., to a variable top diameter not less than 4 inches outside bark.

4. The estimated sound material in cull trees.

Deductions for cull include only the volume in defects which cause the material to be unsuited for cordwood. Sweep and slight crook are not regarded as defects.

Cubic-foot oolume.-This volume includes the same material as the cordwood volume excepting the bark.

International 3,-inch log rule. - A rule for obtaining the board-foot volume of logs derived from the following formula: $Y=\left(0.22 \mathrm{D}^{2}-0.71 \mathrm{D}\right)$ x0.905, for 4 -foot sectıon. Taper allowance: $1 / 2$ inch per 4 linear feet.

Standard cord.-Equivalent to a stack of round or split wood boits measuring 4 by 4 by 8 feet, containing actual volumes of wood and bark as follows: Softwoods, 90 cubic feet; hardwoods, 80 cubic feet.

\section{Growth and Drain}

Growing stock.-The sum of the volumes of all sound trees 5 inches d. b. h. and larger; dead and cull trees and tops of hardwoods not included. 
Forest increment.-The gross volume of wood produced on the growing stock-usually within a year's time.

Mortality.-The volume lost from the growing stock by the death of individual trees through such natural causes as fire, tree competition, old age, disease, insects, drought, and wind.

Net increment.-Forest increment minus annual loss through mortality

Saw-timber or board-foot increment. - The net increment on the sawtimber portion of sawlog-size trees. plus the saw-timber volume in sound trees reaching sawlog size.

Net increment of the total stand. - The net increment on the sound stemwood of softwoods 5 inches d. b. h. and over, on under-sawlog-size hardwoods, and on the sawlog portion of sawlog-size hardwoods, plus the sound-tree volume of all species reaching 5 inches d. b. h. during the increment period. If expressed in cords, bark volume is included; if in cubic feet, bark volume is omitted.

Commodity drain.-The sound-tree growing-stock material utilized plus the sound usable material left in felled trees.

Board-foot drain.-Commodity drain of saw-timber material.
Cordwood drain.--Commodity drain in terms of saw-timber material, the upper stems of sawlog-size softwoods, and small trees ranging from 5 inches to sawlog size.

Cubicfoot drain.-Identical with cordwood drain, except that bark volumes are omitted.

\section{Data by Physiographic Regions}

The following tables present area, volume, increment, and drain statistics for the three major physiographic and economic regions of North Carolina-the Coastal Plain (Forest Survey units 1 and 2), piedmont (Forest Survey unit 3), and mountain (Forest Survey unit 4). They provide a convenient means of appraising and comparing the general forest situation in these distinct divisions of the State.

$\mathrm{T}_{\mathrm{AB1}} \mathrm{E}$ 35.-Land area classifud according to use, by physiographic region, 1938

\begin{tabular}{|c|c|c|c|c|c|c|}
\hline Land use & Coastal & Plain & Piedno & & Mount & \\
\hline $\begin{array}{l}\text { Forest: } 1 \\
\quad \text { Productive } \\
\quad \text { Nonproductive }\end{array}$ & $\begin{array}{l}\text { Acres } \\
9,589,800 \\
13,800\end{array}$ & $\begin{array}{r}\text { Percent } \\
64.0 \\
.1\end{array}$ & $\begin{array}{l}\text { Acres } \\
4,968,100 \\
4,100\end{array}$ & $\begin{array}{l}\text { Percent } \\
47.0 \\
\text { (3) }\end{array}$ & $\begin{array}{l}\text { Acres } \\
3,543.800 \\
53,000\end{array}$ & $\begin{array}{r}\text { Percent } \\
65.7 \\
1.0\end{array}$ \\
\hline Total forest & $9,603,600$ & 64.1 & $4,972,200$ & $4 \bar{\pi} .0$ & $3,596.800$ & 66.7 \\
\hline $\begin{array}{l}\text { Nonforest: } \\
\text { Agriculture: } \\
\quad \text { Old cropland } \\
\quad \text { New cropland } \\
\quad \text { Pasture }\end{array}$ & $\begin{array}{r}4,401,200 \\
114,100 \\
134,500\end{array}$ & $\begin{array}{r}29.3 \\
.8 \\
.9\end{array}$ & $\begin{array}{r}4,563,500 \\
127,900 \\
289,900\end{array}$ & $\begin{array}{r}43.1 \\
-\quad 1.2 \\
2.8\end{array}$ & $\begin{array}{r}896,100 \\
25,300 \\
596,100\end{array}$ & $\begin{array}{r}16.6 \\
.5 \\
11.1\end{array}$ \\
\hline $\begin{array}{l}\text { Total agriculture } \\
\text { Abandoned cropland } \\
\text { Other nonforest }\end{array}$ & $\begin{array}{r}4,649,800 \\
84,800 \\
652,600\end{array}$ & $\begin{array}{r}31.0 \\
.6 \\
4.3\end{array}$ & $\begin{array}{r}4,981,300 \\
121.300 \\
505,000\end{array}$ & $\begin{array}{r}47.1 \\
1.1 \\
4.8\end{array}$ & $\begin{array}{r}1,517,500 \\
120,700 \\
158,200\end{array}$ & $\begin{array}{r}28.2 \\
2.2 \\
2.9\end{array}$ \\
\hline Total nonforest . & $5,387,200$ & 35.9 & $5,607.600$ & 53.0 & $1,796,400$ & 33.3 \\
\hline All us & $14,990,800$ & 100.0 & $10,579,800$ & 100. 0 & $5,393,200$ & 100.0 \\
\hline
\end{tabular}

1 Exclusire of $22 \bar{\imath}, 200$ acres in Great Smoky Mountains National Park.

2 Negligible.

$\mathrm{T}_{\mathrm{ABLE}}$ 36.-Distribution of productive forest area in the three physiogtaphic regions of North Carolina, by forest condition and type, 1938 COASTAL PLAIN

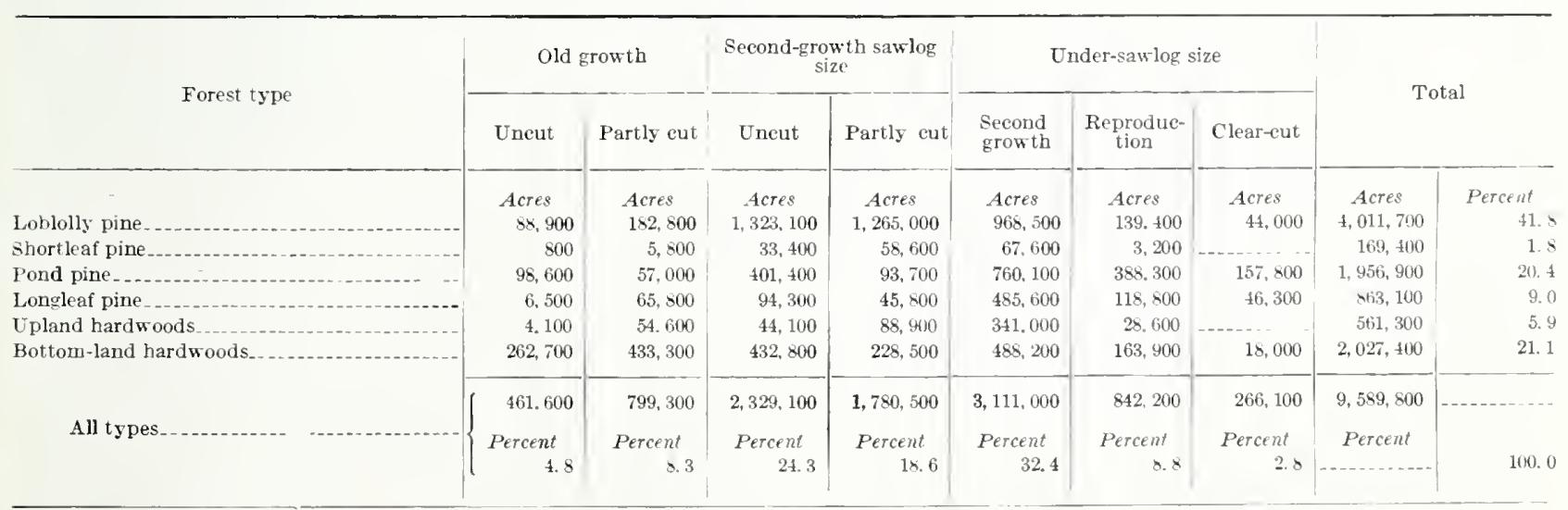


TABLE 36.-Distribution of productive forest area in the three physiographic regions of North Carolina, by forest condition and type, 1938-Con.

PIEDMONT

\begin{tabular}{|c|c|c|c|c|c|c|c|c|c|}
\hline \multirow{2}{*}{ Forest type } & \multicolumn{2}{|c|}{ Old growth } & \multicolumn{2}{|c|}{$\begin{array}{l}\text { Second-growth sawlog } \\
\text { size }\end{array}$} & \multicolumn{3}{|c|}{ Under-sawlog size } & \multirow{2}{*}{\multicolumn{2}{|c|}{ Total }} \\
\hline & Uncut & Partly cut & Uneut & Partly cut & $\begin{array}{l}\text { Second } \\
\text { growth }\end{array}$ & $\underset{\text { tion }}{\text { Reproduc- }}$ & Clear-cut & & \\
\hline Loblolly pine & $\begin{array}{l}\text { Acres } \\
3,300\end{array}$ & $\begin{array}{l}\text { Acres } \\
30,700\end{array}$ & $\begin{array}{l}\text { Acres } \\
149.500\end{array}$ & $\begin{array}{l}\text { Acres } \\
171,100\end{array}$ & $\begin{array}{l}\text { Acres } \\
24 \overline{5}, 400\end{array}$ & $\begin{array}{c}\text { Acres } \\
34,900\end{array}$ & $\begin{array}{l}\text { Acres } \\
\quad 800\end{array}$ & $\begin{array}{l}\text { Acres } \\
638,700\end{array}$ & $\begin{array}{l}\text { Percent } \\
12.8\end{array}$ \\
\hline Shortleaf pine. & 42,300 & $10 \bar{\pi}, 200$ & 662,900 & 450,200 & 966.900 & 83,900 & 800 & $2,314,200$ & 46.6 \\
\hline Virginia pine & 2,500 & 7,500 & 181,900 & 70,600 & 291,500 & 50,700 & 800 & 605,500 & 12. 2 \\
\hline Cove hardwoods $3 . .$. & 3,400 & 6,600 & 8.300 & 5,000 & 5.000 & & & 28,300 & .6 \\
\hline Upland hardwoods & 44,000 & 181,100 & 189,400 & 167,800 & 597,200 & 15,700 & 1,800 & $1,197,000$ & 24.1 \\
\hline \multirow[t]{2}{*}{ Bottom-land hardwoods } & 11,600 & 24,100 & 50,700 & 22,400 & 71,400 & 4,200 & & 184,400 & 3.7 \\
\hline & $10 \bar{\pi}, 100$ & $35 \pi .200$ & $1,242,700$ & $88 \bar{i}, 100$ & $2,180,400$ & $189, \pm 00$ & 4,200 & \multicolumn{2}{|l|}{$4,968,100$} \\
\hline Allty & $\begin{array}{r}\text { Percent } \\
2.1\end{array}$ & $\begin{array}{l}\text { Percent } \\
7.2\end{array}$ & $\begin{array}{r}\text { Percent } \\
25.0\end{array}$ & $\begin{array}{l}\text { Percent } \\
\text { 17. } 9\end{array}$ & $\begin{array}{r}\text { Percent } \\
\text { 43. } 9\end{array}$ & $\begin{array}{r}\text { Percent } \\
\text { 3. } 8\end{array}$ & $\begin{array}{r}\text { Percent } \\
.1\end{array}$ & Percent & 100.0 \\
\hline \multicolumn{10}{|c|}{ MOUNTAIN REGION } \\
\hline White pine & $\begin{array}{l}\text { Acres } \\
31,000\end{array}$ & $\begin{array}{l}\text { Acres } \\
19.500\end{array}$ & $\begin{array}{l}\text { Acres } \\
90,500\end{array}$ & $\begin{array}{l}\text { Acres } \\
58,700\end{array}$ & $\begin{array}{c}\text { Acres } \\
67,700\end{array}$ & $\begin{array}{l}\text { Acres } \\
\quad 3,200\end{array}$ & $\begin{array}{l}\text { Acres } \\
\quad 3,300\end{array}$ & $\begin{array}{l}\text { Acres } \\
2 \pi 3,900\end{array}$ & Percent \\
\hline Shortleaf pine. & 6.500 & 19,600 & 243.000 & 88,100 & 231,600 & 26,100 & .... & $61+, 900$ & 17.4 \\
\hline Yirginia pine... & & & 43. 200 & 21,200 & 106,000 & 20,400 & & 190.300 & $5 . \frac{4}{4}$ \\
\hline Cove hardwoods... & 12,300 & 31,800 & 70.100 & 44,800 & 154.900 & 8,200 & 800 & 322.900 & 9.1 \\
\hline Upland bardwoods. & 96,200 & 169,600 & 391.400 & 241,400 & $1,172,600$ & 49,700 & 20,400 & $2,111,300$ & 60.4 \\
\hline & 146,000 & 240,500 & 838,200 & 454,200 & $1,732,800$ & 107,600 & 24,500 & $3,543,800$ & \\
\hline - & $\begin{array}{l}\text { Percent } \\
4.1\end{array}$ & $\begin{array}{l}\text { Percent } \\
\text { 6.s }\end{array}$ & $\begin{array}{l}\text { Percent } \\
23.7\end{array}$ & $\begin{array}{l}\text { Percent } \\
12,8\end{array}$ & $\begin{array}{r}\text { Percent } \\
48.9\end{array}$ & $\begin{array}{l}\text { Percent } \\
\text { 3.0 }\end{array}$ & $\begin{array}{l}\text { Percent } \\
.7\end{array}$ & Percent & 100.0 \\
\hline
\end{tabular}

1 Estimates of such small acreages are inaccurate because of the sampling method used.

TABLE 37. - Net board-foot volume, by speries group, three log rules, and physiographac disision, 1938

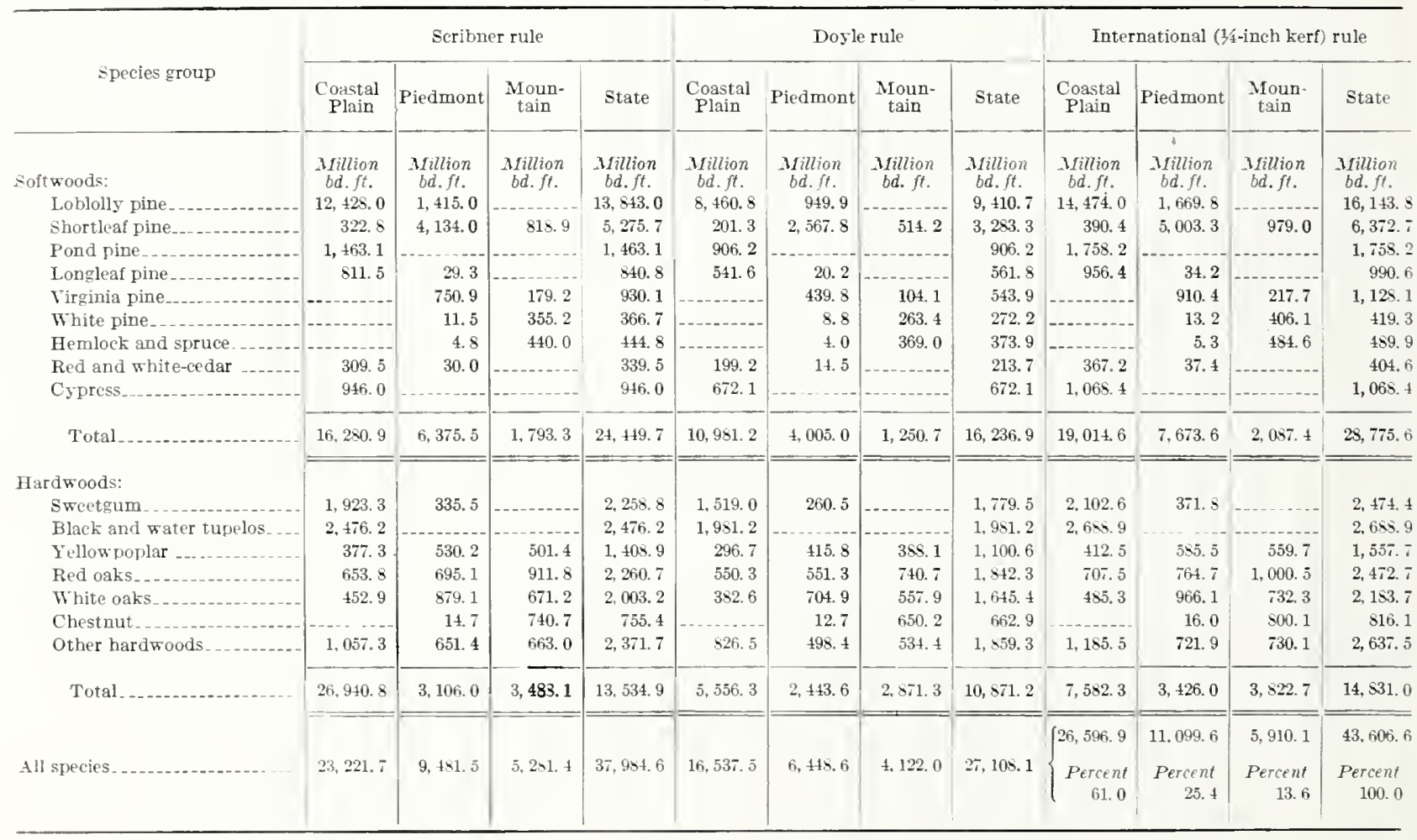


TABLE 38-Net board-foot volume according to the International 1/4-inch rule by species group and forest condition, 1938

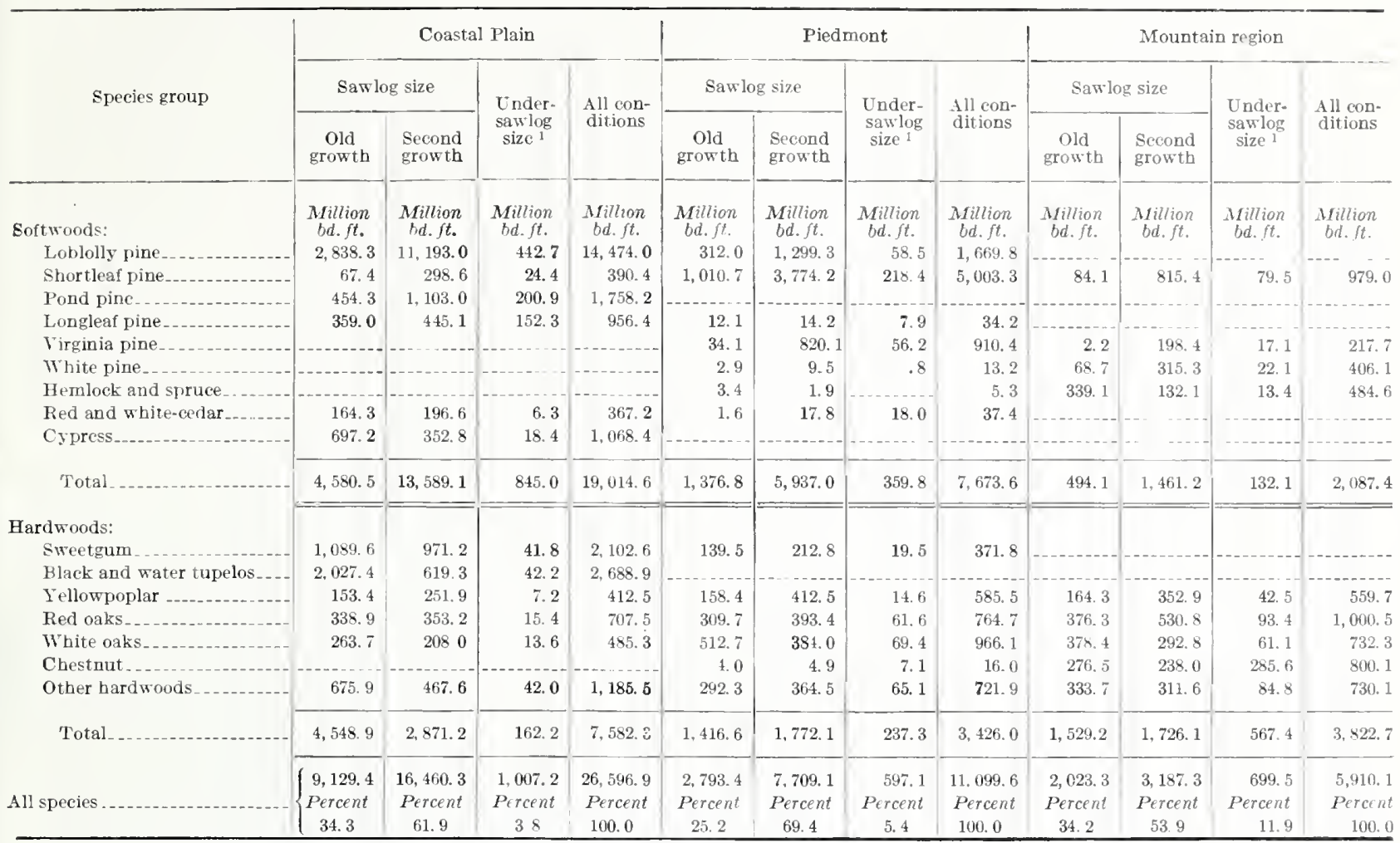

${ }^{1}$ Includes second-growth under-saw $\log$ size, reproduction, and clear-cut conditions.

TAB 1.E 39.-Distribution of the net board-foot colume ${ }^{1}$ of sofwoods and of hardwoods in each physiographic diviston, ${ }^{2}$ by species and tree-diameter group, 1938 [Percent of regional volume for each species group]

\begin{tabular}{|c|c|c|c|c|c|c|c|c|c|c|c|c|}
\hline \multirow{2}{*}{ Species group } & \multicolumn{4}{|c|}{ Coastal Plain } & \multicolumn{4}{|c|}{ Piedmont } & \multicolumn{4}{|c|}{ Mountain region } \\
\hline & $\begin{array}{c}10-12 \\
\text { inches }\end{array}$ & $\begin{array}{c}\text { 14-18 } \\
\text { inches }\end{array}$ & $\begin{array}{c}20-24 \\
\text { inches }\end{array}$ & $\begin{array}{c}26+ \\
\text { inches }\end{array}$ & $\begin{array}{c}\text { 10-12 } \\
\text { inches }\end{array}$ & $\begin{array}{l}\text { 14-18 } \\
\text { inches }\end{array}$ & $\begin{array}{c}20-24 \\
\text { inches }\end{array}$ & $\begin{array}{c}26+ \\
\text { inches }\end{array}$ & $\begin{array}{c}10-12 \\
\text { inches }\end{array}$ & $\begin{array}{l}14-18 \\
\text { inches }\end{array}$ & $\begin{array}{c}20-24 \\
\text { inches }\end{array}$ & $\begin{array}{c}26+ \\
\text { inches }\end{array}$ \\
\hline \multicolumn{13}{|l|}{ Softwoods: } \\
\hline Shortleaf pine & 1. 2 & .6 & .2 & - n & 39.0 & 21.8 & 3.7 & .7 & 24.9 & 18.8 & 3.2 & \\
\hline Pond pine & 4.8 & 4.0 & .4 & .1 & $-\ldots$ & $\ldots$ & $\cdots$ & & & & & \\
\hline Longleaf pine & 2.1 & 2. 2 & .6 & .1 & .1 & .3 & .1 & & & $\cdots$ & & \\
\hline Virginia pine & ...... & $-\ldots$ & - & ..... & 8. 2 & 3.6 & .1 & 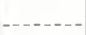 & 7.5 & 2.7 & .1 & \\
\hline White pine $\ldots$ & 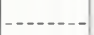 & 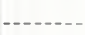 & - & - . & $(3)$ & .1 & .1 & & 5.5 & 7.3 & 4.1 & 2.6 \\
\hline Hemlock & -- & $-\ldots$ & . &.- & $\left({ }^{3}\right)$ & $\left({ }^{3}\right)$ & $\left({ }^{3}\right)$ & $\left({ }^{3}\right)$ & 1. 4 & 4.0 & 4.0 & 9.3 \\
\hline Red spruce.... & & . & & & & & & & 1.6 & 2.4 & .6 & $-\ldots$ \\
\hline Red cedar & $\left({ }^{3}\right)$ & $(3)$ & $\left({ }^{3}\right)$ & - & .4 & .1 & & & & & $\ldots$ & $-\ldots$ \\
\hline White-cedar & .9 & .8 & .1 & $(3)$ & & & & & & & - & - n \\
\hline Cypress & 1.4 & 2.1 & 1.3 & .9 & & - & 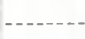 & & & $\ldots$ & $-\ldots$ & $-\ldots$ \\
\hline All softwoods _- & 39.3 & 44.2 & 12.8 & 3.7 & 57.5 & 34.1 & 7.0 & 1.4 & 40.9 & 35.2 & 12.0 & 11. 9 \\
\hline \multicolumn{13}{|l|}{$\begin{array}{l}\text { Hardwoods: } \\
\text { Sweetgum .- }\end{array}$} \\
\hline Black and water tupelos. & 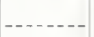 & 20.9 & 10. 6 & 3.9 & & -...- & - & + & & & & 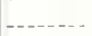 \\
\hline Yellow poplar. & 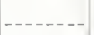 & 3.5 & 1. 2 & .8 & & 11. 2 & 4.8 & 1.1 & & 6.9 & 3.2 & 2.0 \\
\hline Red oaks........ & & 4.0 & 3.1 & 2.2 & & 13.5 & 6.8 & 2.0 & & 15,4 & 7.5 & 4. 1 \\
\hline White oaks...... & - & 2.8 & 1.6 & 2.0 & & 16.5 & 8.0 & 3.6 & & 9.7 & 5.4 & 4. 7 \\
\hline Chestnut & & $-\ldots$ & 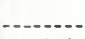 & $-\ldots$ &.--- & .2 & .2 & .1 & & 6.4 & 7.4 & 7. 9 \\
\hline Other hardwoods & & 10.7 & 3.4 & 1. 6 & -....... & 15.2 & 4.5 & 1.4 & & 11.4 & 4.9 & 3. 1 \\
\hline All hardwoods & . & 59.0 & 26.7 & 14.3 & & 64.0 & 27.3 & 8.7 & - & 49.8 & 28.4 & 21.8 \\
\hline
\end{tabular}

1 International $1 / 4$-inch rule. $\quad 2$ For totals for all regions, see table 37, p. $72 . \quad$ Negligible. 
TABLE t0. -Net cordwood volume in stems of sound trees by species group and tree-diameter class, 19381

[Thousand cords]

\begin{tabular}{|c|c|c|c|c|c|c|c|c|c|c|c|c|c|c|c|}
\hline \multirow{2}{*}{ Species group } & \multicolumn{5}{|c|}{ Coastal Plain } & \multicolumn{5}{|c|}{ Piedmont } & \multicolumn{5}{|c|}{ Mountain region } \\
\hline & $\begin{array}{c}6-8 \\
\text { inches }\end{array}$ & $\begin{array}{l}10-12 \\
\text { inches }\end{array}$ & $\begin{array}{l}14-18 \\
\text { inches }\end{array}$ & $\begin{array}{c}20+ \\
\text { inches }\end{array}$ & Total & $\begin{array}{c}6-8 \\
\text { inches }\end{array}$ & $\begin{array}{l}\text { 10-12 } \\
\text { inches }\end{array}$ & $\begin{array}{c}14-18 \\
\text { inches }\end{array}$ & $\begin{array}{c}20+ \\
\text { inches }\end{array}$ & Total & $\begin{array}{c}\text { 6-8 } \\
\text { inches }\end{array}$ & $\begin{array}{c}10-12 \\
\text { inches }\end{array}$ & $\begin{array}{l}\text { 14-18 } \\
\text { inches }\end{array}$ & $\stackrel{20+}{\text { inches }}$ & Total \\
\hline \multicolumn{16}{|l|}{ Soft woods: } \\
\hline Shortleaf pünt.... & 733 & 773 & 334 & 74 & 1,914 & 8,114 & 9,911 & 4,537 & 738 & 23,300 & 1,578 & 1,807 & 1.076 & 159 & 4,620 \\
\hline Pond pine...... & 2. 024 & 3.064 & 2,175 & 211 & 7,474 & & - & $\ldots$ & - & & & & & & -.... \\
\hline Longleaf pine... & 1,076 & 1,256 & 1. 109 & 317 & 3,758 & $2 \overline{7}$ & 32 & 48 & 13 & 120 & & ---- & & ---1 & - - - \\
\hline Virginia pine & - & -..... & - & $\ldots-$ & $\ldots \ldots$ & 1,866 & 1,803 & 724 & 16 & 4,409 & 666 & 452 & 152 & 6 & 1,276 \\
\hline White pine.-. & $\ldots \ldots$ & & --- & $\ldots$ & & 9 & 10 & 11 & 13 & 43 & 399 & 367 & 404 & 308 & 1,4 is \\
\hline Hemlock & & & - & & & 1 & 2 & 3 & 9 & 15. & 82 & 123 & 260 & 682 & 1,147 \\
\hline Red spruce. - & & & -1 & & & & & & & $\cdots$ & 90 & 95 & 117 & 28 & 330 \\
\hline Red cedar ..... & 18 & 10 & 13 & 11 & 52 & 207 & 67 & 22 & & 296 & & & & &.- \\
\hline White-cedar ..... & 439 & 553 & 407 & 59 & 1,458 & & & -- & & & & & & & \\
\hline Cypress & 613 & 693 & 1.037 & 827 & 3,170 & $\cdots$ & -- & -- & $\cdots-$ & - & & - & & & . \\
\hline Total & 14,070 & 24,250 & 22,202 & 6,828 & 67,350 & 12,364 & 14.333 & 7,058 & 1,426 & 35,181 & 2,815 & 2,844 & 2.009 & 1.153 & 8,851 \\
\hline \multicolumn{16}{|l|}{ Hardwools: } \\
\hline Black and water tupelos _- & 3,148 & 4.972 & 4,593 & 2,746 & 15,459 & & 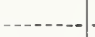 & .... & - & -..- - - & & & & & ... \\
\hline Yellow poplar ${ }^{2}$ & 254 & 376 & 657 & 326 & 1,613 & 794 & 1,135 & 989 & 457 & 3,375 & 640 & 674 & 657 & 451 & 2,422 \\
\hline Red oaks........ & 876 & 965 & 901 & 984 & 3. 726 & 1,135 & 1,488 & 1. 245 & 686 & $4,5.54$ & 1,141 & 1. 483 & 1. 707 & 1,082 & 5,413 \\
\hline White oaks ....... & 1,027 & 1,108 & 632 & 631 & 3,398 & 1,729 & 2,370 & 1,551 & 911 & 6,561 & 963 & 1,120 & 1,200 & 1,023 & 4. 306 \\
\hline Chestnut ...... & $\ldots \ldots$ & $\ldots$ & - & $-\ldots$ & -....... & 38 & 50 & 42 & 65 & 195 & 734 & 1,353 & 816 & 1,686 & 4. 589 \\
\hline Hickory - . & 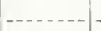 & $\ldots$ & & -- & $\ldots$ & 812 & 1,146 & 670 & 174 & 2. 832 & 388 & 498 & 497 & 247 & 1. 630 \\
\hline Other hardwoods & 2.677 & 2,723 & 2. 228 & 876 & 8,504 & 1,717 & 1,338 & 788 & 307 & 4,150 & 1.360 & 1.310 & 1,117 & 610 & 4,397 \\
\hline \multirow[t]{3}{*}{ Total _. } & 9. 696 & 12,419 & 12.265 & 7,315 & 41,695 & 7.108 & 8,349 & 5,944 & 2,869 & 24,270 & 5,226 & 6. 438 & 5,994 & 5.099 & 22.757 \\
\hline & $\{23,766$ & 36,669 & 34,467 & 14,143 & 109.045 & 19,472 & 22,682 & 13,002 & 4,295 & 59,451 & 8,041 & 9,252 & 8,003 & 6,282 & 31,608 \\
\hline & $\left\{\begin{array}{c}\text { Percent } \\
21.8\end{array}\right.$ & $\begin{array}{c}\text { Percent } \\
33.6\end{array}$ & $\begin{array}{c}\text { Percent } \\
31.6\end{array}$ & $\begin{array}{c}\text { Percent } \\
13.0\end{array}$ & $\begin{array}{c}\text { Percent } \\
100.0\end{array}$ & $\begin{array}{c}\text { Percent } \\
32.8\end{array}$ & $\begin{array}{c}\text { Percent } \\
38.1\end{array}$ & $\begin{array}{c}\text { Percent } \\
21.9\end{array}$ & $\begin{array}{r}\text { Percent } \\
7.2\end{array}$ & $\begin{array}{r}\text { Percent } \\
100.0\end{array}$ & $\begin{array}{c}\text { Percent } \\
25.4\end{array}$ & $\begin{array}{c}\text { Percent } \\
29.4\end{array}$ & $\begin{array}{c}\text { Percent } \\
25.3\end{array}$ & $\begin{array}{c}\text { Percent } \\
19.9\end{array}$ & $\begin{array}{r}\text { Percent } \\
100.0\end{array}$ \\
\hline
\end{tabular}

1 Totals for all regions given in table 17, p. 34 .

a Includes basswood

$T_{\mathrm{ABLE}} 41 .-$ Net volume of all sound material by species group, quality class, and region, 1938

CORDWOOD VOLUME

\begin{tabular}{|c|c|c|c|c|}
\hline Species group and class of material & $\begin{array}{l}\text { Coastal } \\
\text { Plain }\end{array}$ & Piedmont & $\underset{\text { region }}{\text { Mountain }}$ & State \\
\hline Softwoods: & \multirow{6}{*}{$\begin{array}{l}1,000 \\
\text { cords } \\
44,290.7 \\
9,700.7 \\
14,070.2 \\
2,961.8\end{array}$} & \multirow{6}{*}{$\begin{array}{r}1,000 \\
\text { cords } \\
18,386.7 \\
429.7 \\
12.364 .2 \\
1,545.6\end{array}$} & \multirow{6}{*}{$\begin{array}{l}1,000 \\
\text { cords } \\
4,8 i 0.9 \\
1.165 .0 \\
2,814.9 \\
890.0\end{array}$} & \multirow{6}{*}{$\begin{array}{l}1,000 \\
\text { cords } \\
67,548.3 \\
15,295.4 \\
29,249.3 \\
5,397.4\end{array}$} \\
\hline Sawlog-size trees: & & & & \\
\hline Sawlog material . & & & & \\
\hline Upper stems. . . . . & & & & \\
\hline somnd trees under-saw log size ... & & & & \\
\hline Cull trees. & & & & \\
\hline Total & $71,023.4$ & $36,726.2$ & 9. 740.8 & $117,490.4$ \\
\hline Hardwoods: & \multirow{6}{*}{$\begin{array}{l}19.533 .1 \\
10.401 .6 \\
22.162 .0 \\
16.715 .3\end{array}$} & \multirow{6}{*}{$\begin{array}{r}8.787 .4 \\
4,547.9 \\
15,482.6 \\
7,169.5\end{array}$} & \multirow{6}{*}{$\begin{array}{r}11,1 \times 6.0 \\
4,520.5 \\
11,570.7 \\
14,330.4\end{array}$} & \multirow{6}{*}{$\begin{array}{l}39.506 .5 \\
19,470.0 \\
49.215 .3 \\
38,215.2\end{array}$} \\
\hline Sawlog-size trees: & & & & \\
\hline Sawlog material & & & & \\
\hline Upper stenis and limbs & & & & \\
\hline Sound trees under-saw log size . & & & & \\
\hline Cull trees. & & & & \\
\hline Total_. & $68,812.0$ & $35,987.4$ & $41,607.6$ & 146.407 .0 \\
\hline All species.-.-- & $139,535.4$ & $72,713.6$ & $51,348.4$ & $263,897.4$ \\
\hline
\end{tabular}


TABLE 41.-Net Volume of all sound material by species group, quality class, and region, 1938-Continued

CUBIC FOOT YOLUME

Species group and class of material

Softwoods:

Sawlog-size trees:

Sawlog material

Upper stems.

Cull trees.

Total

Hardwoods:

Sawlog-size trees:

Sawlog material

Upper stems and limb

Sound trees under-sawlog size-

Cull trees.

Total.

All species

\begin{tabular}{|c|c|c|c|}
\hline $\begin{array}{c}\text { Coastal } \\
\text { Plain }\end{array}$ & Piedmont & $\begin{array}{l}\text { Mountain } \\
\text { region }\end{array}$ & State \\
\hline $\begin{array}{l}1,000 \\
\text { cubic foet } \\
3,208,240 \\
683,340 \\
931,420 \\
209,270\end{array}$ & $\begin{array}{c}1,000 \\
\text { cubic feet } \\
1,330,200 \\
317,350 \\
837,620 \\
109,900\end{array}$ & $\begin{array}{r}1,000 \\
\text { cubic feet } \\
358,160 \\
84,790 \\
196.080 \\
64,140\end{array}$ & $\begin{array}{l}\text { 1.,000 } \\
\text { cubic feet } \\
4,896,600 \\
1,085,4 \text {. } \\
1,965.120 \\
383,310\end{array}$ \\
\hline $5,032,270$ & $2,595,070$ & 703,170 & $8,330,510$ \\
\hline $\begin{array}{r}1,321,390 \\
617,100 \\
1,407,650 \\
1,070,910\end{array}$ & $\begin{array}{l}575,070 \\
261,100 \\
967,450 \\
457,620\end{array}$ & $\begin{array}{l}574,280 \\
204,820 \\
582.290 \\
541,120\end{array}$ & $\begin{array}{l}2,470,740 \\
1,083,020 \\
2,957,390 \\
2,069,650\end{array}$ \\
\hline $4,417,050$ & $2,261,240$ & $1,902,510$ & 8.580 .800 \\
\hline $9,449,320$ & $4,856,310$ & $2,605,680$ & $16,911,310$ \\
\hline
\end{tabular}

TABLE 42.-Comparison of board-foot increment, mortality, and commodity drain by region, forest condition, and species group, 1938

[MIllion board feet; i. e., 000,000 omitted.]

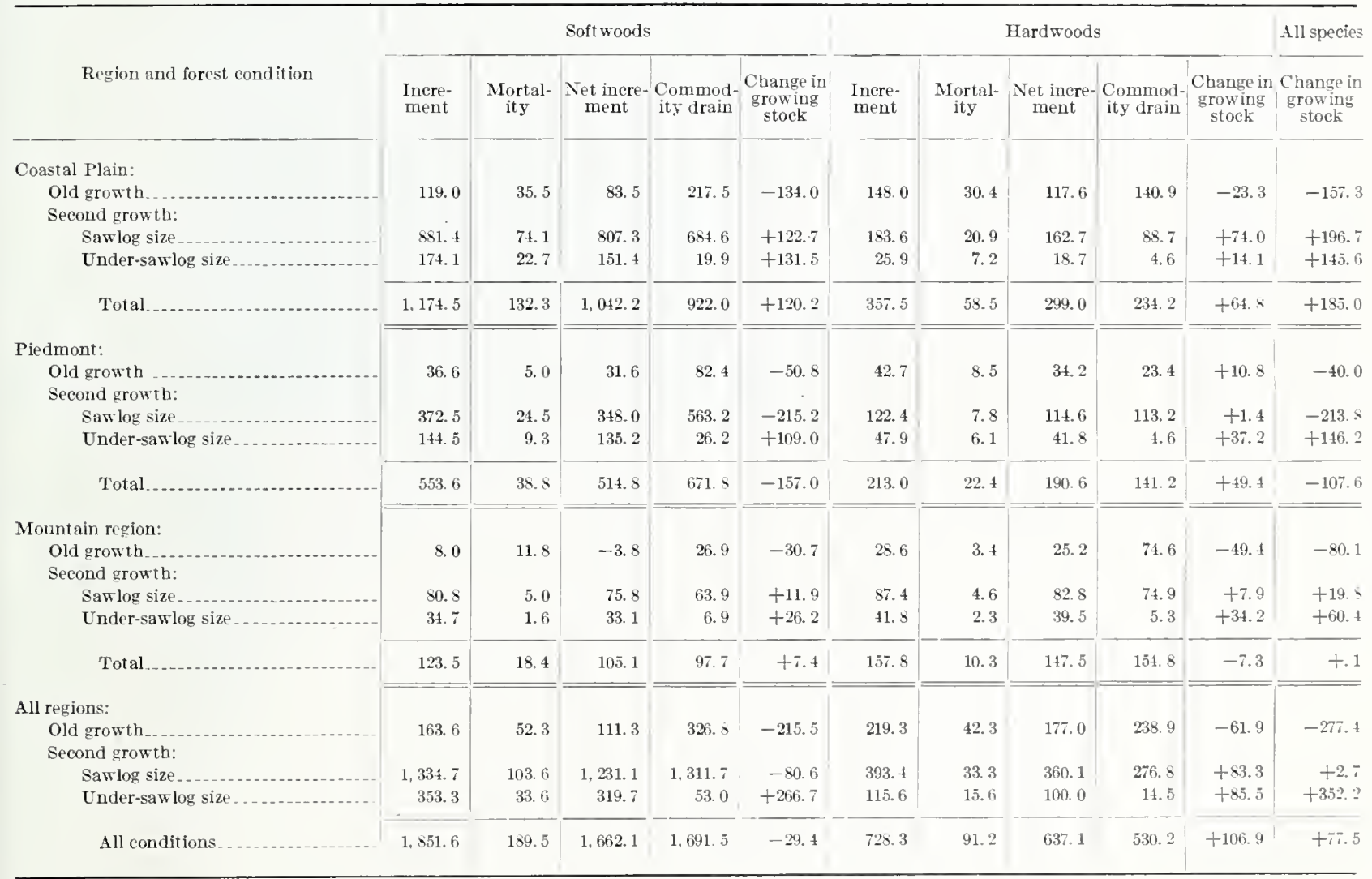


TABLE 43.-Comparison of cubic-fout increment, mortality, and commodity drain by region, forest condition, and species group, 1938

[Thousand cubic feet; i. e. 000 omitted.]

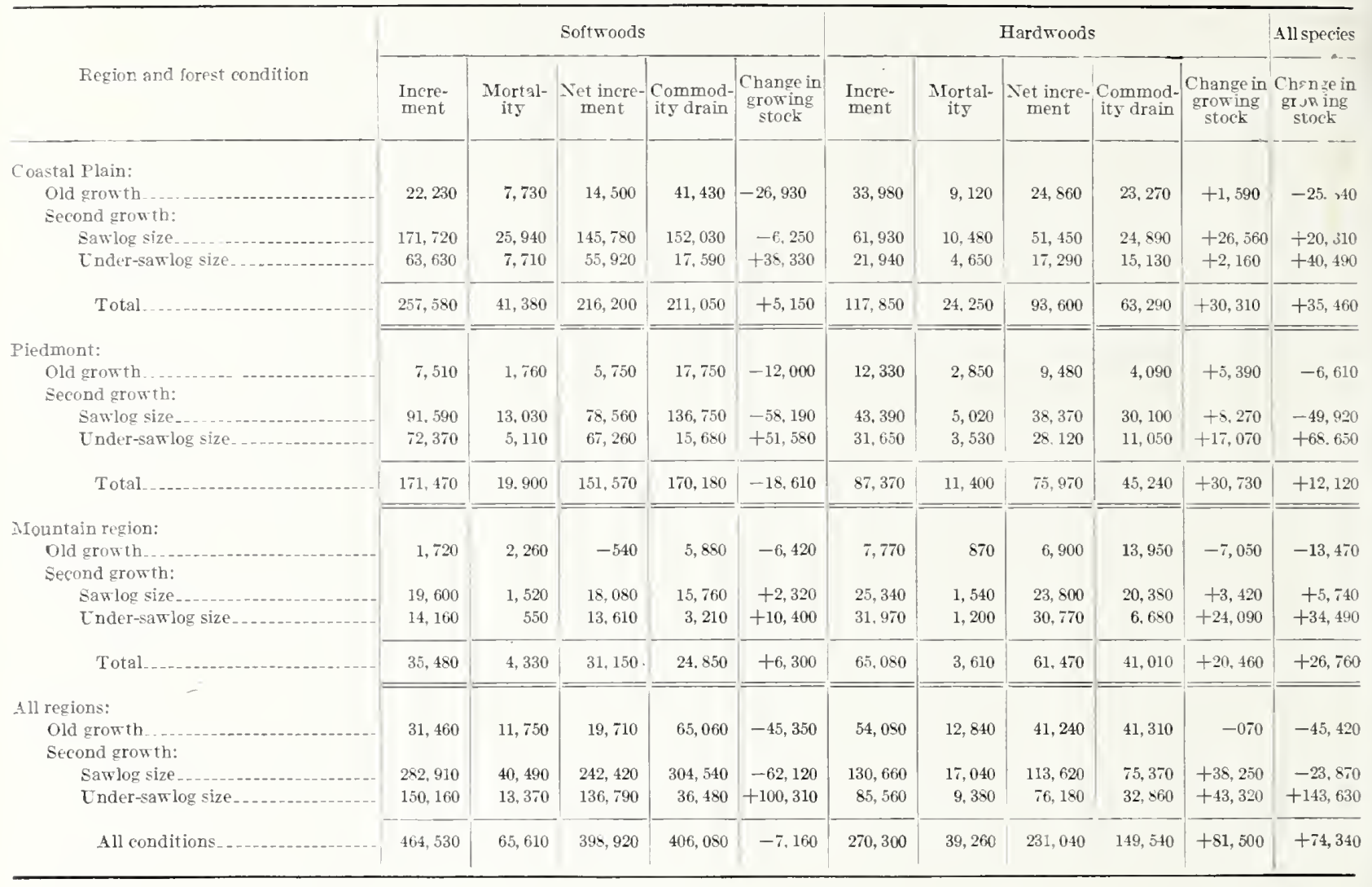




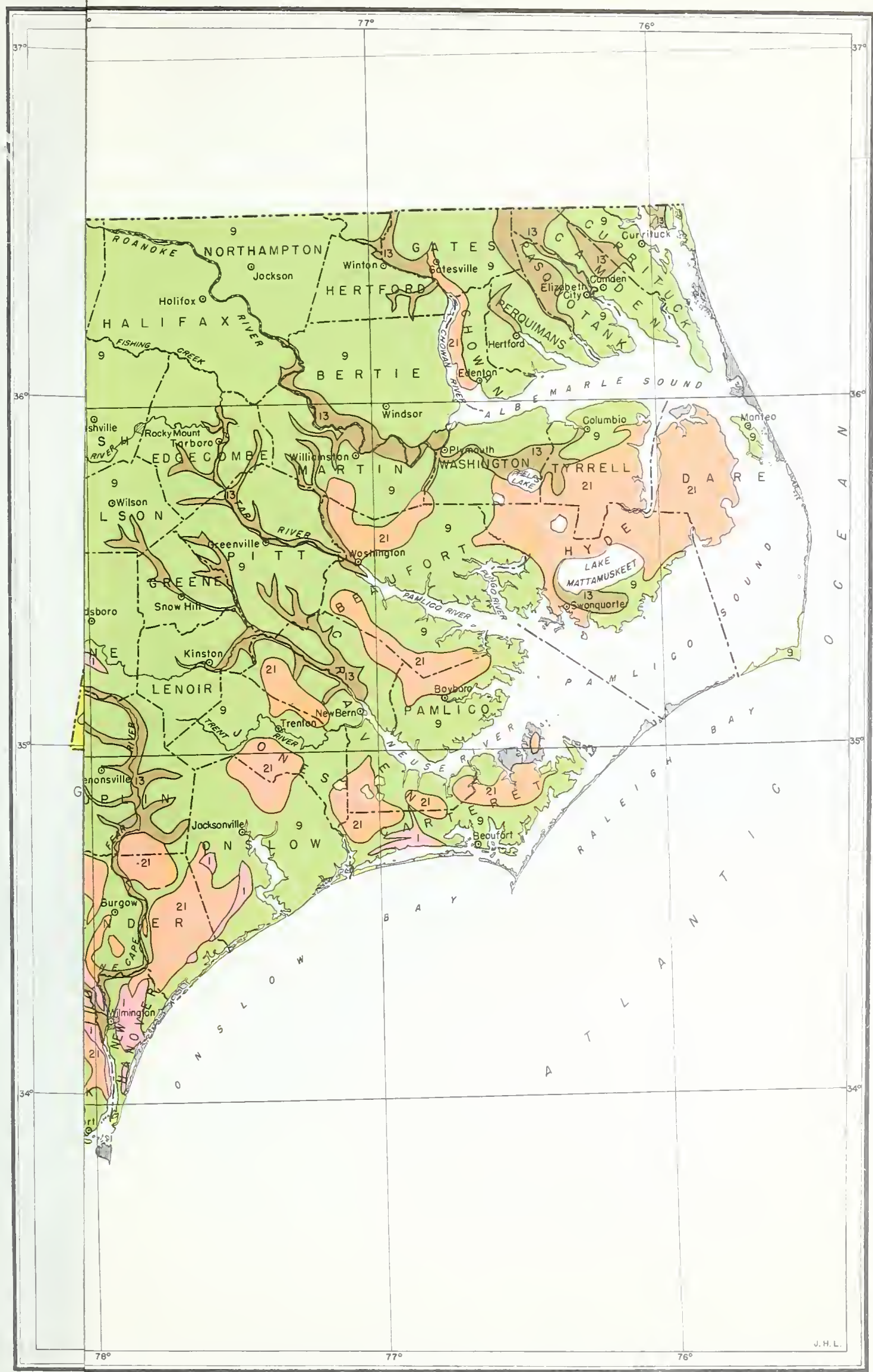

A. Hoen \& Co., In 


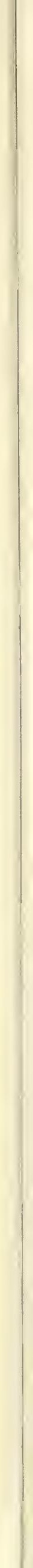




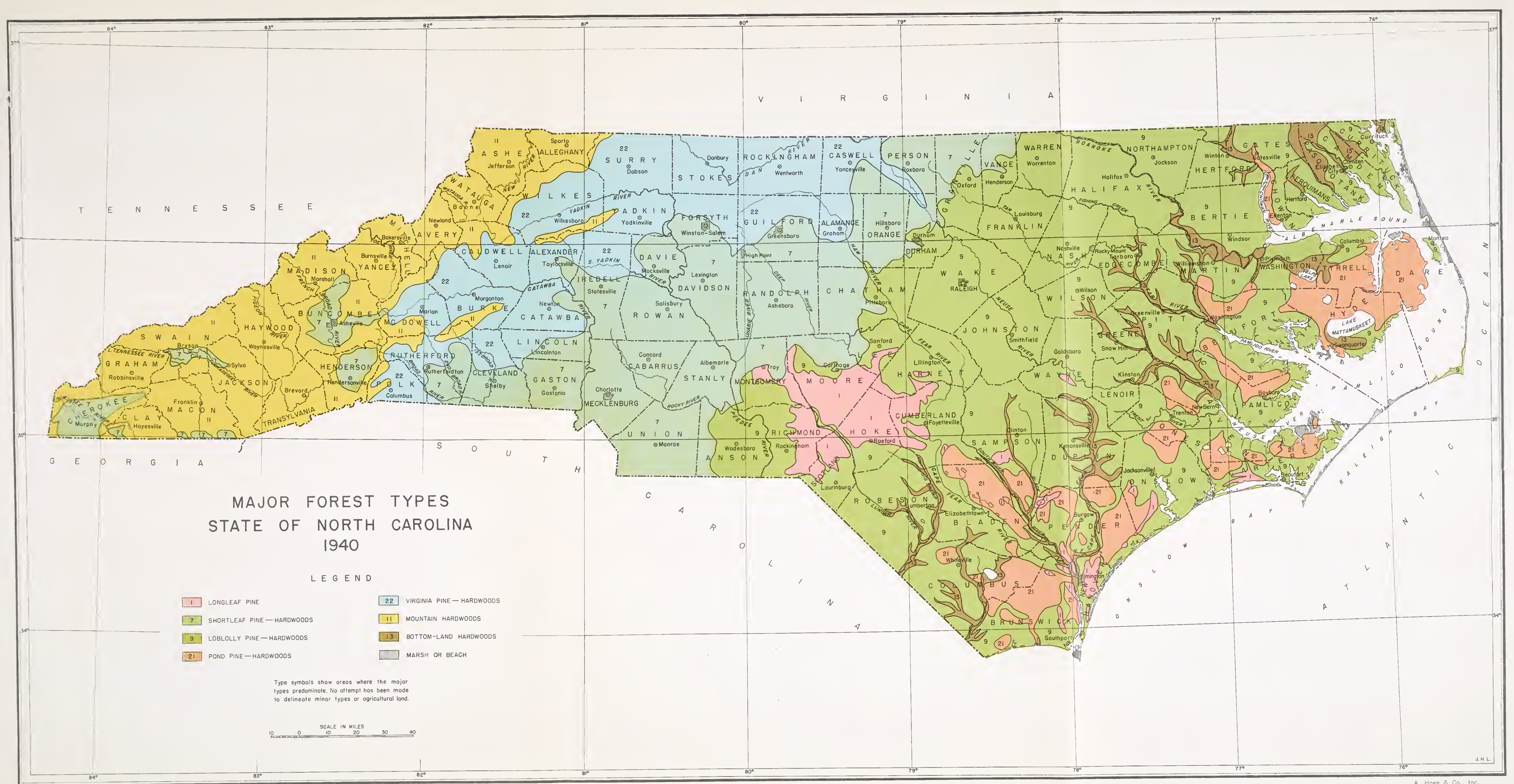



